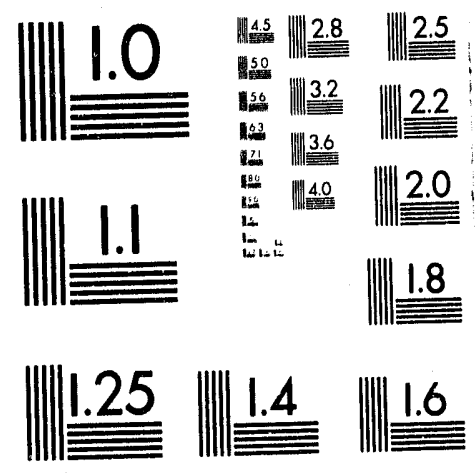



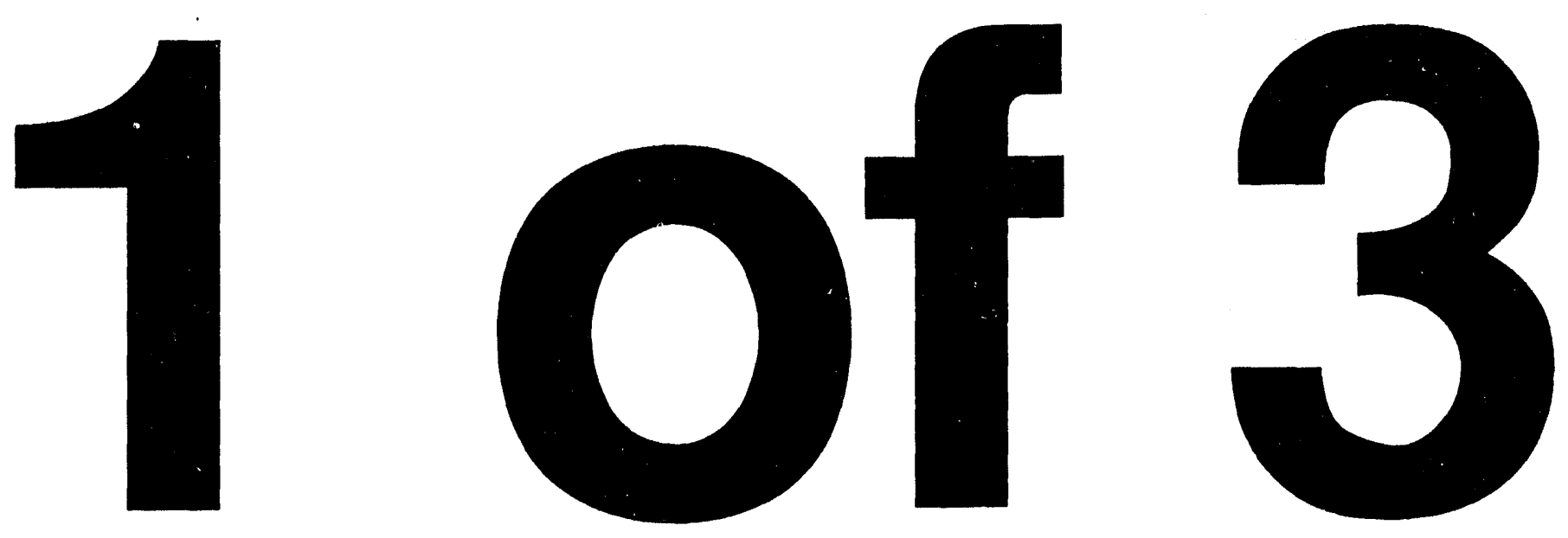


\title{
Production of Low-Cost Hydrogen
}

Final Report

September 1989 - August 1993

Work Performed Under Contract No.: DE-AC21-89MC26367

\author{
For \\ U.S. Department of Energ.] \\ Office of Fossil Energy \\ Morganto'wn Energy Technology Center \\ P.O. Box 830 \\ Morgantown, West Virginia 26507-0880
}

\author{
By \\ Manufacturing and Technology Conversion International, Inc. \\ P.O. Box 21 \\ Columbia, Maryland 21045-0021
}

June 1993 


\section{EXECUTIVE SUMMARY}

This Final Report presents the results of an experimental program sponsored by the Department of Energy, Morgantown Energy Research Center (Contract No. DEAC21-88MC26367) to demonstrate the production of hydrogen from coal, mild gasification chars, and liquefaction bottoiss.

Although the MTCI technoiogy can be utilized for producing hydrogen from almost any carbonaceous feedstock (fossil, biomass and waste), the overall Program objective was to verify at the laboratory scale the ability of the MTCI indirectly heated, fluid-bed gasifier to economically produce a hydrogen-rich product gas from liquefaction by-product streams and from char produced in mild gasification processes. Specifically, the effort was aimed at developing an experimental technology data base to define the process characteristics that would be required for integration into an overall liquefaction system that would result in substantial decreases in the cost of hydrogen for the production of comketitively priced coal-derived liquid fuels.

Another important objective of the proposed effort was to provide a process dato base that could be utilized by the AMOCO Corporation in evaluating the design and economics of an integrated liquefaction process that employs the MTCI gasifier for hydrogen production. The AMOCO Corporation cost-shared this Program with both financial and in-kind participation. Their participation in the project was one element in evaluating the economics of an indirectly heated gasifier to meet the overall program objective of reducing the cost of direct liquefaction processes.

The MTCI technology is an alternative approach for indirectly heated gasification systems that involves the use of a pulsed heat exchanger to provide the endothermic heat of reaction for the indirectly heated gasifier. The system has the potential to overcome the limitations of both the oxygen-blown partial oxidation systems and the two-stage circulating solids systems. In the MTCI process, represented in this instance by a char gasification application, char is fed to a single fluidized bed vessel and reacted with steam to generate a hydrogen-rich product gas. The endothermic heat of reaction is supplied 
indirectly through heat transfer surfaces immersed within the fluid bed. The heat source is derived from the combustion of a portion of the feedstock char or treated gasifier product gas. The combustor-heat exchanger is comprised of a pulsating combustion system in which the heat exchanger is actually the resonance section of the pulse combustor. The combustor pulsations translate into substantially improved heat transfer rates on the fire side of the tubes. Using the above configuration, the MTCI process is capable of generating a synthesis quality product gas without the use of air or expensive oxygen. The product gas is free of both diluent nitrogen and combustion-generated $\mathrm{CO}_{2}$. The complete gasification process is accomplished using only a single vessel, and no circulation of hot solids is needed. Also, since the combustion products can be generated from clean fuel gases, no additional flue gas treatment is needed.

The Program was implemented with a task structure that included an initial analysis assessing the potential benefits of pulse combustion to substantially improve the performance and economics of producing a low-cost hydrogen product from liquefaction residues, mild gasification chars and eventually subbituminous and bituminous coal. Implementation and Test Plans were prepared to bridge the initial assessment data with an experimental program that would provide verification of the technology at the laboratory-scale.

MTCI's existing eight-inch gasifier was modified and recommissioned for operation with the aforementioned feedstocks to provide both short-term characterization tests and long-term tests sufficient to obtain steady-state data for both performance and systems analysis. The data was utilized by MTCI to develop a data base for the conceptual design of a 300-ton/day char facility and to provide technical and economic evaluations of the technology. An independent economic evaluation was also conducted by the AMOCO Corporation and is provided in Appendix $A$ to this report. In addition, a brief description of collateral activities carried on by MTCI and others in evaluating hydrogen purification development and pressurized pulse combustion systems operation were included to provide an overall perspective with respect to the application of the MTCI technology as an alternative to conventional gasification processes for the production of a low-cost hydrogen product. 
Initial efforts to obtain a mild gasification char were unsuccessful and the scope of the program was expanded to include the processing of a subbituminous coal (Black Thunder and Eagle Butte mines) to produce the mild gasification char required to conduct the experimental activities. The MTCI system was configured for the mild gasification process and successfully produced a suite of products including the char required for the experimental program. The AMOCO Corporation provided both in-kind and cash contributions for the mild gasification char production activities. Later on in the project, AMAX Research and Development Company provided a feed char that was originally generated by the Western Research Institute and then further gasified by AMAX. This char was used in a long duration test. In addition to preparing mild gasification char for the required series of tests, an additional test for the direct gasification of the subbituminous coal was also conducted successfully.

Tests were al so conducted for the gasification of ash concentrate (SRC) from Southern Electric International, Southern Clean Fuels Division (SCFD). The ash concentrate was the residue of the coal liquefaction test run by SCFD. The feed material was crushed and screened to $<0.5$-inch size. A total of about 177 pounds of SRC was gasified in the tests.

All of the test activities for: mild gasification to produce a char; the steam reforming of char; ash concentrate and subbituminous coal were successful and prompted an additional set of tests for the steam-reforming of a bituminous coal that included preconditioning and gasifying a Pittsburgh \#8 coal feed and preparing a process design for the concept.

A process evaluation of hydrogen production from direct 1 iquefaction residues, char and coal was made based on the preliminary data base acquired in the characterization tests. The process evaluation focused primarily on the gasifier train and included a consideration of design trade-offs and their impact on economics and performance of a plant.

A comparative economic analysis of partial oxidation coal gasification plants was derived from assessments conducted by Fluor Engineers for the Coolwater coal gasification facility that incorporated a Texaco oxygen-blown coal 
gasifier. The capital and operating cost data was provided for the integrated gasification-combined cycle (IGCC) plant in 1984 dollars. The base cost estimate, known as the "Unphased GCC Plant," was utilized to provide an estimate of the overall capital and operating costs of a Texaco oxygen-blown gasifier and its peripherals and to determine the proportion of these costs attributed to the oxygen production system. Sufficient detail was provided for most of the cost data to separately identify the cost of the gasification system and its peripherals, including the oxygen plant.

A capital cost estimation was calculated for a scaled-up 3,000 tons feed char per day hydrogen plant utilizing the MTCI indirect gasification technology. The plant was approximately to the same scale as the oxygen-blown gasification plant analyzed by Fluor Engineers. The cost of the MTCI gasifier was estimated by scaling up an existing black liquor gasifier design. The capital cost estimates included the gasification plant and peripherals only and did not include the power generation facility.

The estimated capital cost of the MTCI indirect gasification hydrogen plant is 54 percent less than the estimated capital cost of the oxygen-blown gasification hydrogen plant. Assuming an annual fixed operation and maintenance cost of 3.8 percent of the capital cost and 15 percent for a capital carrying charge, the annual cost of running the hydrogen plant based on the MTCI indirect gasification technology would be 34.5 million dollars per year exclusive of feedstock charge. Compared with the annual cost of the sample oxygen-blown hydrogen plant (88.1 million dollars annually), this is a 61 percent reduction in hydrogen production cost.

Based on this work and the literature, it was evident that oxygen costs have an enormous impact on the total hydrogen production costs for partial oxidation gasifier systems. The indirect gasification process does not require consumption of oxygen and appears to have the potential to reduce hydrogen production costs by over 30 percent. 
However, an independent study by AMOCO using the MTCI data and comparing the MTCI system with the Texaco gasifier arrived at a different conclusion, i.e., that a low-cost, high-pressure gasifier would be necessary to compete successfully with the Texaco system primarily by eliminating the expensive crude gas compression requirement. On the other hand, a study on the production of hydrogen from biomass and coal completed in $1993^{(15)}$ also using ASPEN seems to be in agreement with the MTCI and other studies.

Key conclusions from the assessment are summarized as follows:

- By avoiding the use of cryogenic oxygen and enhancing hydrogen yield per pound of char, over 60 percent reduction in hydrogen production costs can be achieved.

- The MTCI indirect gasifier has the potential to increase hydrogen yield by 10 percent and reduce $\mathrm{CO}_{2}$ removal requirements by 40 percent compared to alternative partial oxidation gasifiers.

- 96 percent of gasification efficiency is easily achievable in the MTCI indirect gasifier.

- The MTCI gasifier characterizes its low liquid by-product yield.

- Limestone bed material is highly recommended especially for gasifying ash concentrate.

- Gasifier can be operated at a relatively mild temperature range of $1350^{\circ} \mathrm{F}-1450^{\circ} \mathrm{F}$ for char and lignite feedstocks. For ash concentrate feedstock, higher gasifier temperatures $\left(1500^{\circ} \mathrm{F}\right)$ are recommended as well as co-gasifying char.

- A pressurized system could provide additional benefits in yield and lowered capital cost as well as process advantages for IGCC systems.

The indirect gasification process offers a unique potential for significantIy reducing the cost of hydrogen production from ash concentrates or mild gasification chars at atmospheric pressures and even greater potential as a pressurized system. By avoiding the need for a cryogenic oxygen plant, the capital cost of the gasification facility can be reduced by 25 percent when operating costs for the cryogenic plant are included even with the compression costs necessary for the atmospheric system. This would translate to a reduction in total hydrogen production costs of approximately 30 percent. 
Furthermore, the indirect gasifier shows potential for increasing hydrogen yield by 10 percent and reducing acid gas removal requirements by 40 percent. This alone is estimated to provide additional cost savings of up to 10 percent.

Since hydrogen production accounts for a significant fraction of total cost for a direct liquefaction facility, the indirect gasifier is anticipated to offer a unique opportunity for improving the economics of premium liquid production from the nation's huge coal resources. 


\section{TABLE OF CONTENTS}

Page

EXECUTIVE SUMMARY ........................ . . i

1.0 INTRODUCTION . . . . . . . . . . . . . . . . . . 1-1

1.1 PROGRAM OBJECTIVES ................. 1 . 1

1.2 BACKGROUND .................. 1-2

1.3 DEVELOPMENT BACKGROUND ................ 1-6

1.4 TASK STRUCTURE ................. . . 1-6

2.0 SYSTEM DESIGN AND TEST PROCEDURES . . . . . . . . . . . 2-1

2.1 SYSTEM DESCRIPTION . . . . . . . . . . . . 2-1

2.2 ANALYSIS METHODOLOGY ............... 2-12

3.0 TEST AND ANALYSIS ................... . . . . . . . . .

3.1 INITIAL SHAKEDOWN TESTS ............. 3-2

3.2 MILD GASIFICATION CHAR PRODUCTION . . . . . . . . 3-4

3.3 MILD GASIFICATION DATA ANALYSIS . . . . . . . . 3-5

3.4 MILD CHAR GASIFICATION .............. 3-22

3.5 MILD CHAR GASIFICATION DATA ANALYSIS . . . . . . . 3-33

3.6 LONG DURATION MILD CHAR GASIFICATION CHAR TESTS . . . . 3-39

3.7 SRC GASIFICATION TEST . . . . . . . . . . . . 3-44

3.8 LONG-TERM SRC RESIDUES GASIFICATION TEST . . . . . . 3-53

3.9 DIRECT GASIFICATION OF SUBBITUMINOUS COALS . . . . . . 3-61

3.10 BITUMINOUS COAL DEVOLATILIZATION AND GASIFICATION . • . 3-68

3.11 GASIFICATION OF PREOXIDIZED COAL . . . . . . . . 3-76 


\section{TABLE OF CONTENTS}

\section{(CONT'D)}

Page

4.0 TECHNICAL AND ECONOMIC EVALUATION .............. . . . . .

4.1 CAPITAL AND OPERATING COST CONSIDERATIONS ...... 4-1

4.2 TECHNICAL ANALYSIS OF PROCESS ........... 4-5

4.2.1 Gasification Rate............. 4-8

4.2.2 Limits of Gasifier Production Rate ...... 4-10

5.0 ENGINEERING ANALYSIS OF A CONCEPTUAL 300-TPD CHAR

INDIRECT GASIFICATION PLANT FOR HYDROGEN PRODUCTION . . . . . 5-1

6.0 CONCLISSIONS ...................... . . . . . . . . .

REFERENCES ........................ R-1 


\section{LIST OF FIGURES}

Page

FIGURE 1-1 SCHEMATIC OF THE MTCI INDIRECT CHAR GASIFIER . . . 1-5

FIGURE 2-1 PROCESS FLOW DIAGRAM FOR INDIRECT GASIFIER

TEST RIG . . . . . . . . . . . . . . $2-2$

FIGURE 2-2 GASIFIER DESIGN AS MODIFIED FOR CHAR

GASIFICATION TESTS . . . . . . . . . . . $2-4$

FIGURE 2-3 ORIGINAL GASIFIER DESIGN FOR REACTIVE

BIOMASS FEEDSTOCKS ............. . 2 . 2

FIGURE 2-4 PRIMARY SAMPLE COLLECTION POINTS .......... 2-10

FIGURE 3-1 COAL FEED AND GAS PRODUCTION vS. TIME

MILD GASIFICATION PRODUCTION RUN ........ 3-. 38

FIGURE 3-2 REACTOR BED TEMPERATURE VS. TIME

MILD GASIFICATION PRODUCTION RUN . . . . . . . . 3-19

FIGURE 3-3 PRODUCT GAS COMPOSITION MILD GASIFICATION

PRODUCTION RUN ................ 3-20

FIGURE 3-4 CHROMATOGRAPHS OF PRODUCT GAS MILD GASIFICATION

PRODUCTION RUN ...................... $3-21$

FIGURE 3-5 CHAR FEED AND GAS PRODUCTION vs. TIME (Test \#2) . . 3-27

FIGURE 3-6 BED TEMPERATURE vs. TIME (Test \#2) . . . . . . . 3-28

FIGURE 3-7 PRODUCT GAS (Test \#2) . . . . . . . . . . . . 3-29

FIGURE 3-8 CHAR FEED AND GAS PRODUCTION vs. TIME (Test \#3) . . 3-30

FIGURE 3-9 REACTOR BED TEMPERATURE vs. TIME (Test \#3) . . . . 3-31

FIGURE 3-10 PRODUCT GAS (Test \#3) . . . . . . . . . . . . 3-32

FIGURE 3-11 PRODUCT GAS COMPOSITION FOR CHAR

FIGURE 3-12 AVERAGE BED TEMPERATURE PROFILE FOR CHAR

GASIFICATION TEST . . . . . . . . . . . . . . $3-46$

FIGURE 3-13 AVERAGE BED TEMPERATURE PROFILE (SRC RESIDUE

GASIFICATION TEST $10 / 8 / 92$ ) . . . . . . . . . . . $3-55$ 


\section{LIST OF FIGURES}

(CONT'D)

Page

FIGURE 3-14 TEMPERATURE HISTORY (SRC RESIDUE

GASIFICATION TEST 10/8/92) . . . . . . . . . . 3-56

FIGURE 3-15 BED TEMPERATURE HISTORY (SRC RESIDUE

GASIFICATION TEST 10/8/92) . . . . . . . . . 3-57

FIGURE 3-16 PRODUCT GAS GENERATION RATE (SRC RESIDUE

GASIFICATION TEST 10/8/92) . . . . . . . . . . 3-58

FIGURE 3-17 PRODUCT GAS COMPOSITION (SRC RESIDUE

GASIFICATION TEST 10/8/92) ........... 3-59

FIGURE 3-18 BITUMINOUS COAL GASIFIER WITH SHORT RESIDENCE

TIME PREHEATER .................. 3-71

FIGURE 3-19 BITUMINOUS COAL PREOXIDIZER/GASIFIER . . . . . . . 3-74

FIGURE 3-20 PRODUCT GAS COMPOSITION FOR TEST \#1 . . . . . . . 3-78

FIGURE 3-21 PRODUCT GAS GENERATION RATE FOR TEST \#1 . . . . . . 3-80

FIGURE 3-22 PULSE COMBUSTOR, PULSE COMBUSTOR EXIT, AND AVERAGE

BED TEMPERATURE HISTORIES FOR TEST RUN \#1 . . . . . 3-81

FIGURE 3-23 AVERAGE BED TEMPERATURE HISTORY - CAKING COAL

PREOXIDATION/GASIFICATION TEST \#2......... 3-84

FIGURE 3-24 BED TEMPERATURE PROFILE - CAKING COAL

PREOXIDATION/GASIFICATION TEST \#2. . . . . . . . . 3-85

FIGURE 3-25 PRODUCT GAS COMPOSITION - CAKING COAL

PREOXIDATION/GASIFICATION TEST \#2........ $3-86$

FIGURE 3-26 GAS PRODUCT RATE - CAKING COAL PREOXIDATION/

GASIFICATION TEST \#2.............. . . 3-88

FIGURE 3-27 AVERAGE BED TEMPERATURE - PREOXIDIZED

CAKING COAL GASIFICATION TEST \#3 ......... . 3-89

FIGURE 3-28 BED TEMPERATURE HISTORY - CAKING COAL

PREOXIDATION/GASIFICATION TEST \#3.......... 3-91

FIGURE 3-29 PRODUCT GAS COMPOSITION - CAKING COAL

GASIFICATION TEST $\# 3$. . . . . . . . . . . 3-92 


\section{LIST OF FIGURES}

\section{(CONT'D)}

Page

FIGURE 4-1 PRELIMINARY PROCESS DIAGRAM FOR 4-6

FIGURE 4-2 GASIFIER MATERIAL BALANCE . . . . . . . . . . 4-15

FIGURE 4-3 THROUGHPUT OF INDIRECT GASIFICATION REACTOR . . . . 4-21

FIGURE 5-1 PROCESS FLOW DIAGRAM FOR CONCEPTUAL 300-TPD

CHAR GASIFICATION PLANT . . . . . . . . . . . 5-2 


\section{LIST OF TABLES}

Page

TABLE 2-1 PLACKETT-BURNAN DESIGN MATRIX .......... 2-13

TABLE 2-2 VALUES OF HIGH AND LOW LEVELS FOR INDEPENDENT

VARIABLES IN PLACKETT-BURMAN DESIGN MATRIX ..... 2-14

TABLE 2-3 EXPERIMENTAL PROGRAM TEST MATRIX . . . . . . . . 2-14

TABLE 3-1 COAL AND MINERAL ANALYSIS ............. 3-3

TABLE 3-2 SIEVE ANALYSIS OF WYODAK COALS . . . . . . . . . 3-4

TABLE 3-3 CHAR PRODUCTION TEST SUMMARY . . . . . . . . . . 3-6

TABLE 3-4 PRODUCT GAS ANALYSIS .............. . . . . . . .

TABLE 3-5 ANALYSES OF SOLID SAMPLES FROM BLACK THUNDER

COAL PYROLYSIS AT MTCI . . . . . . . . . . . 3-8

TABLE 3-6 ANALYSES OF LIQUID SAMPLES FROM BLACK THUNDER

COAL PYROLYSIS AT MTCI . . . . . . . . . . . 3-9

TABLE 3-7 ANALYSES OF COMPOSITE LIQUID SAMPLES FROM

BLACK THUNDER COAL PYROLYSIS AT MTCI ....... . 3-10

TABLE 3-8 ESTIMATES OF COAL LIQUID QUALITY BASED ON

ANALYSIS OF HEAVY LIQUID $150^{\circ} \mathrm{C}+$ FRACTION . . . . . 3-11

TABLE 3-9 COMPARISCN OF THE CHEMICAL ANALYSIS DATA

FROM AMOCO AND CORE LABORATORIES . . . . . . . . 3-12

$\begin{array}{ll}\text { TABLE 3-10 } & \text { COMPARISON OF THE CHEMICAL ANALYSIS DATA FROM } \\ & \text { AMOCO, CORE LABS AND DESERT ANALYTICS . . . . . . }\end{array}$

TABLE 3-11 OVERALL MATERIAL BALANCE . . . . . . . . . . . 3-15

TABLE 3-12 PERCENT YIELD OF PRODUCTS ............. . . . . . . .

TABLE 3-13 CARBON BALANCE ................. . . . . . . . . . .

TABLE 3-14 PRODUCT GAS ANALYSIS FROM CHAR GASIFICATION

TABLE 3-15 PRODUCT GAS ANALYSIS FROM CHAR GASIFICATION

(Test \#2).................... 3-24 


\section{LIST OF TABLES \\ (CONT'D)}

Page

TABLE 3-16 PRODUCT GAS ANALYSIS FROM CHAR GASIFICATION

(Test \#3).................. 3-... 3

TABLE 3-17 CHAR GASIFICATION TEST SUMMARY (Test \#2) . . . . . . 3-26

TABLE 3-18 CHAR GASIFICATION TEST SUMMARY (Test \#3) . . . . . . 3-26

TABLE 3-19 CHEMICAL ANALYSIS OF CHAR ........... 3-34

TABLE 3-20 TOTAL ORGANIC CARBON IN THE GASIFICATION

PRODUCTS ................... 3-. . . . . . . .

TABLE 3-21 MATERIAL BALANCE FOR CHAR GASIFICATION TEST \#2 . . 3-35

TABLE 3-22 MATERIAL BALANCE FOR CHAR GASIFICATION TEST \#2 . . . 3-37

TABLE 3-23 COMPARISON OF MTCI RESULTS WITH THAT OF

TABLE 3-24 ULTIMATE ANALYSIS OF VARIOUS FEEDSTOCKS TESTED . . . 3-40

TABLE 3-25 OPERATING CONDITIONS AND PRODUCT GAS ANALYSIS . . . 3-41

TABLE 3-26 MASS BALANCE FOR CHAR GASIFICATION TESTS . . . . . 3-41

TABLE 3-27 ELEMENTAL BALANCE FOR CHAR GASIFICATION TEST . . . 3-42

TABLE 3-28 CHAR GASIFICATION - HYDROGEN + OXYGEN BALANCE . . . 3-43

TABLE 3-29 CHAR GASIFICATION - 6/22/92 TO 6/4/92 ....... 3-43

TABLE 3-30 SRC GASIFICATION TEST CONDITIONS . . . . . . . . 3-47

$\begin{array}{ll}\text { TABLE 3-31 } & \text { PRODUCT GAS ANALYSIS OF SRC GASIFICATION } \\ & \text { (DeC. 17, 1990) . . . . . . . . . . . . . . 3-47 }\end{array}$

$\begin{array}{ll}\text { TABLE 3-32 } & \text { PRODUCT GAS ANALYSIS OF SRC GASIFICATION } \\ & \text { (DeC. 20, 1990) . . . . . . . . . . . . 3-48 }\end{array}$

TABLE 3-33 PRELIMINARY MATERIAL BALANCE (Dec. 17, 1990) . . . 3-49

TABLE 3-34 PRELIMINARY MATERIAL BALANCE (Dec. 20, 1990) . . . 3-49 


\section{LIST OF TABLES}

\section{(CONT'D)}

Page

TABLE 3-35 PROXIMATE AND ULTIMATE ANALYSIS (\% AS RECEIVED) . . 3-51

TABLE 3-36 CARBON BALANCE FOR DECEMBER 17, 1990

GASIFICATION TEST . . . . . . . . . . . 3-52

TABLE 3-37 CARBON BALANCE FOR DECEMBER 20, 1990

GASIFICATION TEST............. 3-52

TABLE 3-38 PRELIMINARY MASS BALANCE FOR TEST 10/8/92 . . . . 3-54

TABLL 3-39 AVERAGE PRODUCT GAS COMPOSITION - TEST 10/8/92 . . 3-60

TABLE 3-40 CARBON AND MATERIAL BALANCE SRC TEST

NORMALIZED FOR CARBON BALANCE ......... . . 3-62

TABLE 3-41 OPERATION SUMMARY AND PRODUCT GAS ANALYSIS

FOR JANUARY 17, 1991, TEST ........... 3-63

TABLE 3-42 MATERIAL BALANCE (January 17, 1991) . . . . . . 3-63

TABLE 3-43 FEED MATERIAL ANALYSIS . . . . . . . . . . 3-64

TABLE 3-44 CARBON CONTENTS ANALYSIS FOR BED SAMPLES AND

CYCLONE SAMPLES OF JANUARY 17,1991 TEST $(\%) \ldots$. . . 3-66

TABLE 3-45 ORGANIC CARBON BALANCE FOR COAL GASIFICATION

TEST ON JANUARY $17,1991 \ldots . . . . . . . . .3-66$

TABLE 3-46 DRY PRODUCT GAS ANALYSIS FOR JANUARY 17, 1991 TEST

AFTER ADJUSTMENT FOR $\mathrm{CO}_{2}$ RELEASED FROM THE BED . . . 3-67

TABLE 3-47 TCLP EXTRACTION OF HEAVY METAL POLLUTANTS . . . . . 3-68

TABLE 3-48 BITUMINOUS COAL PRETREATMENT RESULTS . . . . . . 3-72

TABLE 3-49 BITUMINOUS COAL PRETREATMENT RESULTS . . . . . . . . 3-76

TABLE 3-50 MASS BALANCE SUMMARY FOR TEST \#1 . . . . . . . . . 3-77

TABLE 3-51 AVERAGE PRODUCT GAS COMPOSITION, TEST \#1 . . . . . 3-79

TABLE 3-52 MASS BALANCE SUMMARY FOR TEST \#2 . . . . . . . . 3-83 


\section{LIST OF TABLES}

\section{(CONT'D)}

Page

TABLE 3-53 AVERAGE PRODUCT GAS COMPOSITION, TEST \#2 . . . . . 3-87

TABLE 3-54 MASS BALANCE SUMMARY FOR TEST \#3 ......... 3-93

TABLE 3-55 AVERAGE PRODUCT GAS COMPOSITION, TEST \#3 . . . . 3-94

TABLE 3-56 CARBON AND MATERIAL BALANCE FOR TEST \#1

NORMALIZED FOR CARBON BALANCE . . . . . . . . 3-95

TABLE 3-57 CARBON AND MATERIAL BALANCE FOR TEST \#2

NORMALIZED FOR CARBON BALANCE . . . . . . . . . 3-96

TABLE 3-58 CARBON AND MATERIAL BALANCE FOR TEST \#3

NORMALIZED FOR CARBON BALANCE .......... . $3-97$

TABLE 4-1 SUMMARY OF SYSTEM PERFORMANCE COST ESTIMATE BASIS . . 4-2

TABLE 4-2 CAPITAL COST ESTIMATE, UNPHASED CGG PLANT $(3,260 \mathrm{~T} / \mathrm{D})$................. . . . . 4-4

TABLE 4-3 PREDICTED SPECIFIC THROUGHPUT $\left(1 \mathrm{~b} / \mathrm{hr} / \mathrm{ft}^{3}\right) \mathrm{vs}$. TEMPERATURE AND PRESSURE ............. 4-9

TABLE 4-4 PRESSURIZED PULSE COMBUSTION TEST DATA . . . . . 4-13

TABLE 4-5 SIMULATED COLD GAS THERMAL EFFICIENCY AS A

FUNCTION OF INDIRECT G.ASIFIER TEMPERATURES . . . . 4-18

TABLE 5-1 MATERIAL BALANCE FOR INDIRECT GASIFIER HYDROGEN FROM CHAR (300-TPD BASIS) ........ 5-3

TABLE 5-2 MAJOR EQUIPMENT LIST FOR 300-T/D CONCEPTUAL DESIGN . 5-5

TABLE 5-3 PULSED INDIRECT GASIFIER DESIGN CRITERIA . . . . . . 5-6

TABLE 5-4 SPECIFICATIONS AND DUTIES FOR HEAT EXCHANGERS . . . . 5-7

TABLE 5-5 SPECIFICATIONS FOR PUMPS AND BLOWERS . . . . . 5-8

TABLE 5-6 SPECIFICATIONS FOR VESSELS . . . . . . . . . 5-9

TABLE 5-7 CAPITAL COST ESTIMATE FOR TWO HYDROGEN PLANTS (IN MILLIONS OF 1991 DOLLARS) ......... . . 5-10

TABLE 6-1 PRODUCT GAS COMPARISON $\left(\mathrm{H}_{2}, \mathrm{CO}, \mathrm{CO}_{2}\right.$ only) ..... 6-3 
Significant technical progress has been made over the last decade to develop efficient processes for upgrading coal resources to distillable hydrocarbons which may be used to displace petroleum-derived fuels. While several different direct liquefaction routes are under investigation, each of them have in common the need for large quantities of hydrogen to convert the aromatic coal matrix to liquid products in the normal distillation range, and for hydrotreating to improve liquid product quality. In fact, it has been estimated that the production, recovery, and efficient use of hydrogen accounts for over 50 percent of the capital cost of the liquefaction facility. (1) For this reason, improved methods for producing low-cost hydrogen are essential to the operating economics of the liquefaction process.

This Final Report provides an assessment of the application of the MTCI indirect gasification technology for the production of low-cost hydrogen from coal feedstocks. The MTCI gasification technology is unique in that it overcomes many of the problems and issues associated with direct and other indirectly heated coal gasification systems. Although the MTCI technology can be utilized for producing hydrogen from almost any carbonaceous feedstock (fossil, biomass and waste), this report presents the results of an experimental program sponsored by the Department of Energy, Morgantown Energy Research Center, to demonstrate the production of hydrogen from coal, mild gasification chars, and liquefaction bottoms.

\subsection{PROGRAM OBJECTIVES}

The overall Program objective was to verify at the laboratory scale, the ability of the MTCI indirectly heated fluid-bed gasifier to economically produce a hydrogen-rich product gas from liquefaction by-product streams and from char produced in mild gasification processes. The proposed effort was aimed at developing an experimental technology data base by defining the process characteristics that would be required for process integration into an overall 
liquefaction system. This could result in substantial decreases in the cost of hydrogen for the production of competitively priced coal-derived liquid fuels.

Another important objective of the proposed effort was to provide a process data base that can be utilized by the AMOCO Corporation in evaluating the design and economics of an integrated liquefaction process which employs the MTCI gasifier for hydrogen production. The AMOCO Corporation cost-shared this Program with both financial and in-kind participation. Their participation in the project was an important element in evaluating the economics of an indirectly heated gasifier to meet the overall program objective of reducing the cost of direct liquefaction processes.

\subsection{BACKGROUND}

Gasification systems can be broadly classified by the mechanism used to supply heat to the reaction load. These systems can be further distinguished by the means of gas-solid contact, gasifier operating conditions, nature of ash discharge, and producer gas quality.

Among the principal mechanisms for supplying heat to the gasifier include in-situ partial oxidation, hot solids recirculation, and indirect heat transfer by means of immersed heat exchangers. In partial oxidation units, an admixture of steam and oxidant are reacted directly with the carbonaceous feedstock to generate a carbon monoxide-rich fuel gas product. These systems are generally noted for their physical simplicity, but suffer from the intimate mixing of combustion products with the steam-char gasification yields.

The earliest partial oxidation gasifiers consisted of the air-blown variety which were intended to provide low-grade fuel for industrial heating and power generation. The fuel gases so produced contained nearly 50 percent nitrogen and thus were wholly unsuited for use as synthesis gas feedstocks, such as for SNG manufacture or high purity hydrogen production.

To overcome the product quality limitations of the air-blown gasifier, partial oxidation units were developed which were capable of operating on essentially pure oxygen recovered from the cryogenic separation of air. By 
utilizing cryogenic oxygen, a nitrogen-free fuel gas product could be generated suitable for a variety of end uses. Furthermore, the use of oxygen allows practical operation under high-temperature slagging conditions by significantly reducing sensible heat losses associated with the nitrogen diluent thereby increasing cold gas thermal efficiency. Notable examples of the oxygen-blown slagging gasifier include the Lurgi fixed-bed, wet-bottom gasifier, and the Texaco and Shell entrained-flow coal gasifiers.

While the use of oxvgen extends the field of application for partial oxidation units, cryogenic air separation is both a capital and energy-intensive process. Therefore, attempts were made to avoid its use by segregating combustion products from gasification products, thereby excluding both nitrogen and combustion-generated carbon dioxide from the gas train.

One general approach achieving this objective involves the recirculation of hot solids between a gasification vessel and a char combustion vessel. For instance, in the $\mathrm{CO}_{2}$-Acceptor Process developed by Conoco Coal Development Company, coal is fed to a fluidized bed gasifier and reacted with steam at 1500 to $1550^{\circ} \mathrm{F}$. Heat for the gasification reaction is provided by circulating partially calcined limestone which combines exothermically with $\mathrm{CO}_{2}$ in the gasifier. Residual char from the gasifier is transported to the combustor where it is reacted with air, increasing the circulating solids temperature to $1850^{\circ} \mathrm{F}$ and regenerating the exothermic lime reactant. In this way, nitrogen-containing combustion products are passed only through the combustor circuit, and a nitrogen-free, medium-Btu gas is produced solely in the gasifier vessel. Other examples of gasification schemes relying on similar principles include the Battelle, Exxon and the Cogas recirculation gasifiers.

While the circulating solids gasification processes achieve the objective of producing a nitrogen-free synthesis gas without the consumption of expensive cryogenic oxygen, they present several drawbacks. First, the technology requires the use of two separate vessels to complete the gasification circuit. Second, more complex solids handling equipment are required to control the flow of hot circulation solids throughout the system. Third, since solids are reacted in two separate stages, both the product gas and combustor flue gas are contaminated 
with particulates and sulfur-bearing gases. This requires the use of two independent and costly clean-up systems to control emissions from the gasification plant.

The MTCI technology is an alternative approach for indirectly heated gasification systems that involves the use of a pulsed heat exchanger to provide the endothermic heat of reaction for the indirectly heated gasifier. The system has the potential to overcome the limitations of both the oxygen-blown partial oxidation systems and the two-stage circulating solids systems. In the MTCI process, represented in this instance by a char gasification application, Eiqure 1-1, char is fed to a single fluidized bed vessel and reacted with steam to generate a hydrogen-rich product gas. The endothermic heat of reaction is supplied indirectly through heat transfer surfaces immersed with in the fluid bed. The heat source is derived from the combustion of a portion of the feedstock char or treated gasifier product gas. The combustor-heat exchanger is comprised of a pulsating combustion system in which the heat exchanger is actually the resonance section of the pulse combustor. The combustor pulsations translate into substantially improved heat transfer rates on the fire side of the tubes. Using the above configuration, the MTCI process is capable of generating a synthesis quality product gas without the use of air or expensive oxygen. The product gas is free of both diluent nitrogen and combustion-generated $\mathrm{CO}_{2}$. The complete gasification process is accomplished using only a single vessel, and no circulation of hot solids is needed. Also, since the combustion products can be generated from clean fuel gases, no additional flue gas treatment is needed.

It is evident that the MTCI indirect coal gasification process exhibits a unique potential for cost-effective hydrogen production from raw coal, mild gasification char, or de-ashing residues. A more detailed process description and evaluation will be presented in later sections, including direct comparison with conventional systems. The following section provides a brief description of the development background for the MTCI process. 


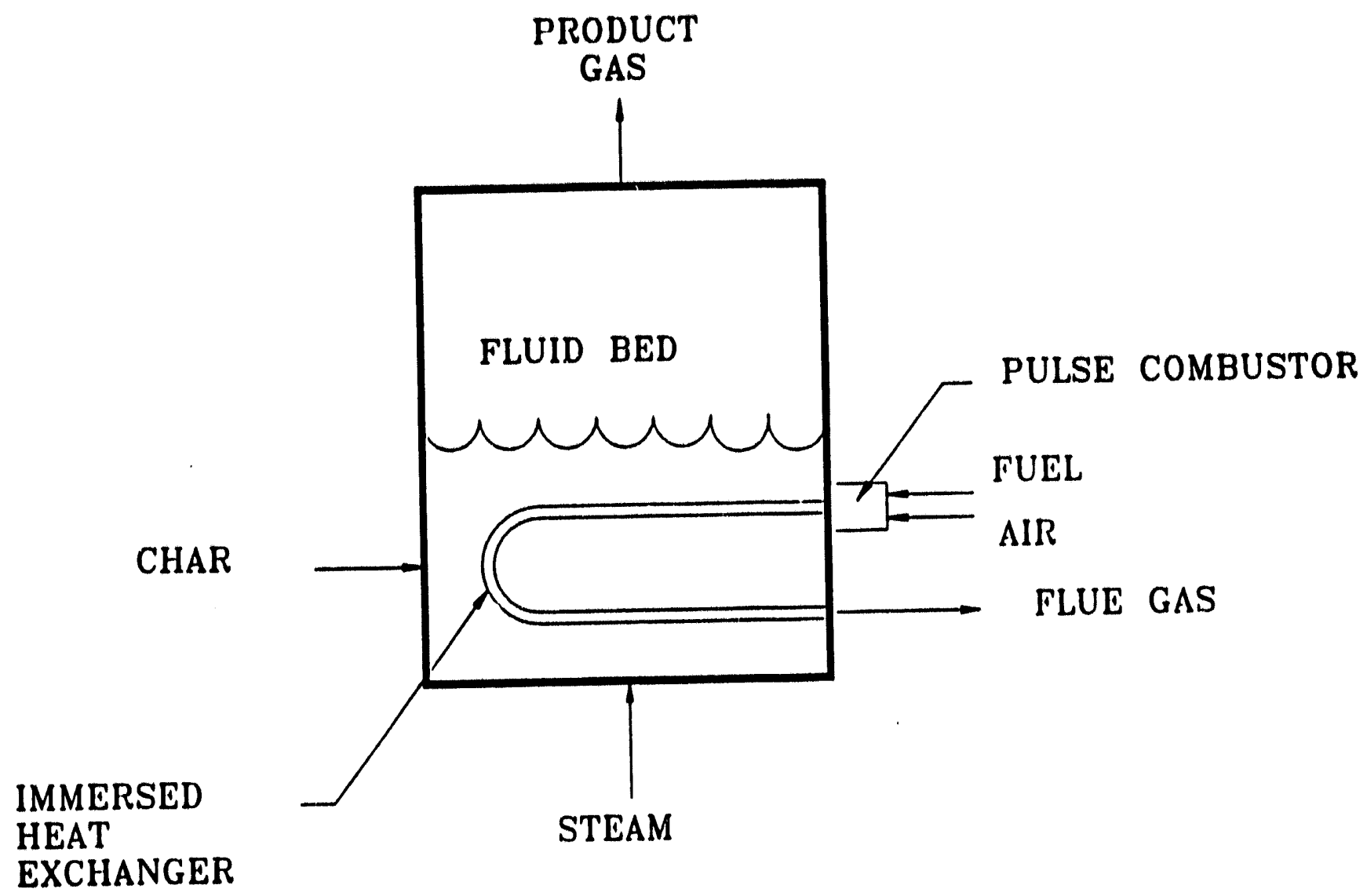

FIGURE 1-1: SCHEMATIC OF THE MTCI INDIRECT CHAR GASIFIER 


\subsection{DEVELOPMENT BACKGROUND}

MTCI's proprietary pulse-enhanced, indirect, steam gasification technology was first experimentally investigated under a DOE/SBIR program conducted from 1984 to $1986 .{ }^{(2)}$ The objective of that program was to establish the basic capability of the gasifier to produce a medium-Btu product gas from biomass feedstock using an indirect heat transfer mechanism significantly enhanced by pulsating combustion.

The successful completion of proof-of-principle testing was followed by process characterization in a PDU during the pariod from 1986 to $1988 .{ }^{(3)}$ This program, which was jointly funded by DOE, the California Energy Commission, and the Weyerhaeuser Paper Company and C.T. Main, extended the range of test feed. stocks to include primary industrial sludge waste and black liquor (a pulping byproduct).

For the reactive biomass materials investigated under these programs, the MTCI gasifier demonstrated high carbon conversion efficiencies (up to $95 \%$ gas plus liquids) at relatively modest gasifier operating temperatures $\left(1250^{\circ} \mathrm{F}\right.$ to $1350^{\circ} \mathrm{F}$ ). Product gases, which typically ranged in heating value from 350 to $410 \mathrm{Btu} / \mathrm{scf}$, exhibited properties suitable for use as synthes is gas feedstocks. Subsequent test projects for the DOE and EPA with lignite, municipal sludge waste, and refuse-derived fuels confirmed and verified the uniqueness of the technology to process a wide variety of carbon-containing materials to form a hydrogen-rich syngas.

The positive results of the tests have also confirmed the commercial potential for economical gasification of reactive feedstocks, particularly waste sludges, which would otherwise be landfilled.

\subsection{TASK STRUCTURE}

\section{TASK 1: Project DefinItION}

Provide a preliminary analysis to assess the potential benefits of pulse combustion to substantially improve the economics and for the indirectly heated steam gasification of 1 iquefaction residues and mild gasification chars, relative 
to conventional gasification systems. The assessment focuses upon the gasifier train and considers gasifier design trade-off issues that impact the capital and operating costs, the relation between feedstock properties and gasifier performance, gasifier heat and material balance, system reliability and complexity, and the effect of gasifier performance, yields, and contaminant levels for the subsequent purification and use of the hydrogen product syngas for use in direct iqquefaction processes.

Provide an implementation plan to bridge the assessment data with the experimental program. The plan provides a guide for basic hardware definition and design criteria, feedstock specifications, catalyst selections, and gasifier performance criteria.

Provide a detailed test plan including specifications of experimental process conditions to be investigated and the gasifier performance variables to be measured. The experimental conditions include the following with the ranges spectfied.

- Feedstock type: mild gasification chars, direct liquefaction residues

- Feedstock feed rate: 10-30 lb/hour

- Steam/carbon ratio: 2-5

- Gasifier temperature: $1400-1750^{\circ} \mathrm{F}$

- Fluidization velocity: $2-5 \mathrm{ft} / \mathrm{second}$

- Catalyst type: calcium aluminate, $\mathrm{CaO} / \mathrm{K}_{2} \mathrm{O} /$ sand

- Calcium in sorbent/feedstock sulfur ratio: 1.5-3.0

The performance variables include the following:

- Carbon conversion efficiency

- Char yield, tar/oil, and gas yields

- Gas composition

- Char and tar/oil analyses, including weight percentages of carbon, hydrogen, nitrogen, sulfur, oxygen, and ash 
- Sulfur capture efficiency

- Catalyst, sorbent, and char elutriation rate

- Analytical tests will be performed to measure these variables for each run.

The approximate numbers of mild gasification char samples, liquefaction residue samples, and experimental runs were defined. Mass balances and elemental balances will be analyzed for each run.

The experimental program utilizes an existing eight-inch diameter reactor that incorporates two pulse-combustor fire tubes. Provide detailed designs for the necessary experimental modifications required to carry out the experimental program, including feeder(s) capable of handling both mild gasification char and direct liquefaction residues, a cyclone separator for collecting elutriated char/fly ash, sorbent, and catalyst, a fluid-bed solids draw-off port, a complete gas analysis train, including condensate collection capability, and a gas chromatograph capable of resolving gas species through $C_{4}$ and selected sulfur compounds.

\section{TASK 2: IEST PREPARATION AND EXECUTION}

An existing pulse-combustion heated fluidized bed gasifier shall be modified for the gasification tests using mild gasification char and direct liquefaction residues with appropriate analys is of the resulting samples and operating data.

MTCI's existing eight-inch gasifier shall be modified and recommissioned for operation with mild gasification chars and liquefaction bottoms. The unit shall undergo shakedown testing to calibrate control instrumentation, develop fluidization data, and confirm reliable operation of feed systems, combustor components, and analytical instrumentation. Char samples shall be obtained from experimental mild gasification facilities for testing in the indirectly heated steam gasifier. The char feedstock shall be fed to the gasifier using an in-bed injection screw. Gasification tests shall be conducted over a range of temperatures, throughput rates, and steam-to-carbon ratios. A typical test run shall cover a feed period of approximately 4 to 6 hours, which is sufficient to obtain 
steady-state operation in the eight-inch gasifier. Gas analyses shall be made at half-hour intervals. Cyclone char/ash samples and condensate samples shall be collected on an hourly basis. At the conclusion of the test, each hourly cyclone and condensate sample shall be analyzed for carbon, ash, and water if necessary, for analyzing char, tar/oil, and dry gas yields for each test run as percent of as-received, moisture and ash-free (MAF) char feedstocks processed.

Direct liquefaction residues (ash concentrates) for testing shall be obtained from the Wilsonville pilot plant. The material shall be heated and pumped to the gasifier or fed to the gasifier using an injection screw feeder, dependent upon the physical properties of the feedstock. Gasification test runs shall be conducted at several different temperatures, throughput rates, and steam-to-carbon ratios. A typical test run shall cover a feed period of approximately four to six hours which is sufficient to obtain steady-state operation in the eight-inch gasifier. Gas analyses shall be taken at half-hour intervals. Cycione char/ash samples and condensate samples shall be collected on an hourly basis. At the conclusion of the test period, each hourly cyclone and condensate sample shall be analyzed for carbon, ash, and water if necessary, to allow calculation of the char, tar/oil, and dry gas yields for the test run as percents of as-received and moisture and ash-free (MAF) coal fed. An overall material balance and elemental balances shall be made. These will include evaluation of carbon in the char, condensate, dry gas stream, and bed inventory, information on dry gas composition, including the hydrogen content, and sulfur breakthrough. At the end of the test series with each feedstock type, reaction conditions will be identified for use in the system analysis to be done in Task 3 .

\section{TASK 3: SYSTEM ANALYSIS}

Test data from Task 2 shall be used to define the specific performance characteristics of the gasification step. The data shall be used to evaluate the system economics, performance, and interface requirements for the advanced steam gasifier/hydrogen generator integrated with an advanced direct liquefaction plant. The experimental data shall be used to provide information regarding the relative balance of 1 iquefaction residue and mild gasification char which must be gasified to satisfy the liquefaction plant hydrogen demand. 
A preliminary scale-up design for the hydrogen generator shall be prepared at a commercially significant capacity range, based on this data. This design shall provide the basis for developing hydrogen production costs in the liquefaction plant environment. AMOCO Corporation will provide an evaluation of the design and provide MTCI with the necessary inputs for system integration for coal liquefaction plants (and/or mild gasification plants.) 


\section{SECTION 2.0 \\ SYSTEM DESIGN AND TEST PROCEDURES}

\subsection{SYSTEM DESCRIPTION}

\section{PROCESS FLOW SCHEME}

A process flow diagram for the indirect gasifier test rig is shown in Figure 2-1. Saturated steam, generated in boiler $\mathrm{H}-1$, is metered through a flow orifice and preheated to approximately $900^{\circ} \mathrm{F}$ in an electric resistance superheater E-1. The steam is then introduced into the base of the gasifier R-1 through a network of distribution nozzles.

Char is manually fed to the gasifier feed bin $x-1$. The feed bin delivers coal to a metering bin using pneumatically operated slide gate valves. The metering bin contains three speed-controlled screws delivering char to the watercooled injection screw. The constant speed injection screw then delivers coal to the fluid-bed gasifier.

The gasifier R-1 is constructed from an 8 -inch stainless steel she 11 which expands to 12 inches in the freeboard region. The shell contains four pulsating indirect heat transfer tubes that serve as the resonance section of the pulsating combustor. The combustor is located at the base of the reactor as well as the heat exchanger providing the heat of reaction to the fluid bed. Flue gases exiting from the pulsating heat transfer tubes enter a decoupling plenum and are vented to the atmosphere through an induced draft fan.

The product gases from the gasifier enter a recirculation cyclone $V-1$. The recirculation cyclone captures elutriated coarse material which is reinjected into the fluid bed by means of an eductor $X-3$. A second cyclone $V-2$ captures additional entrained fines which are collected in a storage drum $V-3$.

The hot product gases are then quenched and scrubbed in venturi $X-5$ and the bulk of the steam contained within the product gases is condensed. The cooled and cleaned gases are then metered through a flow orifice and combusted in 


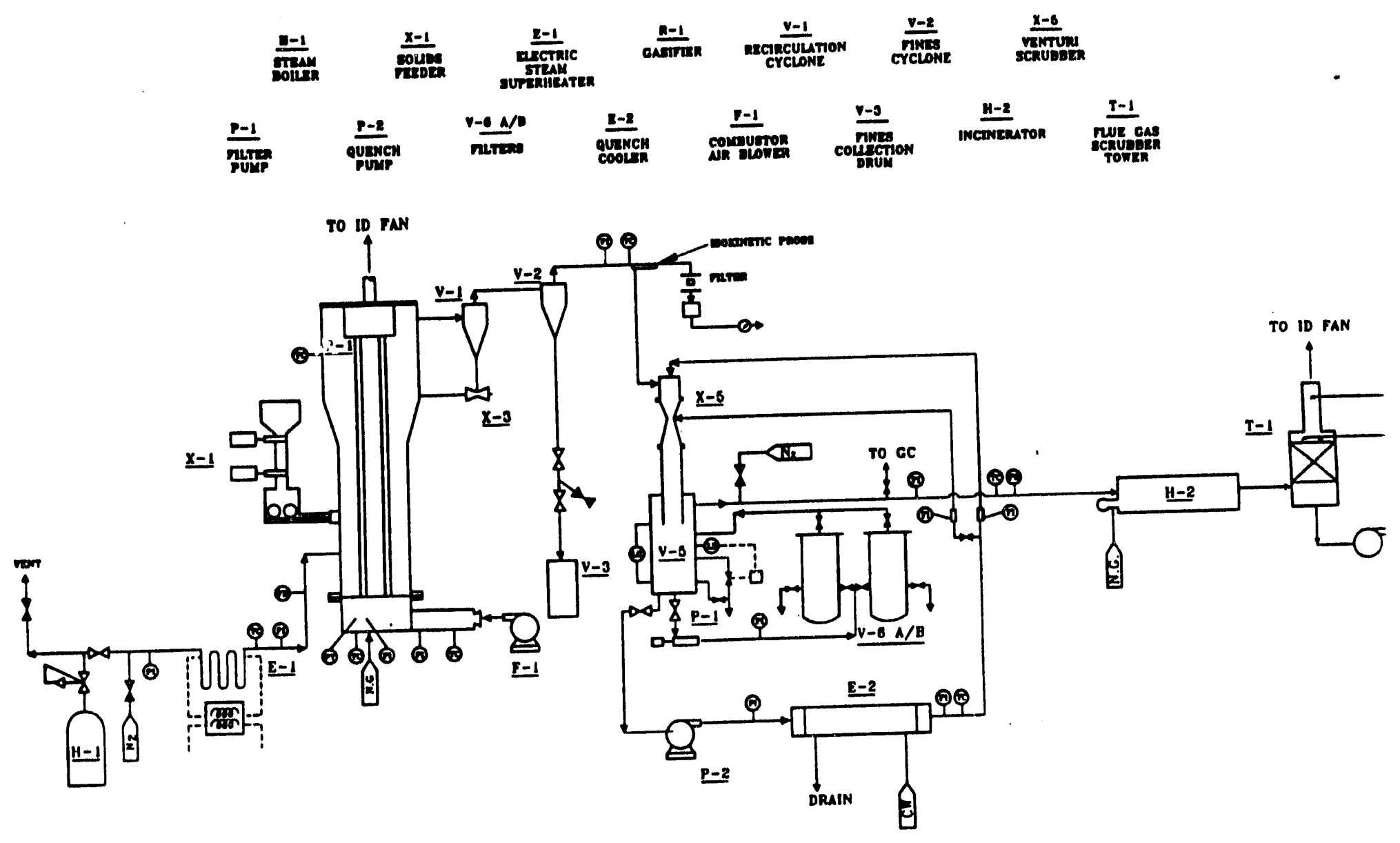

FIGURE 2-1: PROCESS FLOW DIAGRAM FOR INDIRECT GASIFIER TEST RIG 
incinerator $\mathrm{H}-2$. The incinerator flue gases are then quenched and scrubbed in a packed tower employing a circulating alkaline solution.

The venturi quench/scrubber system consists of two independent flow circuits. Quench water collected in V-5 is continuously circulated through a pressure cartridge filter to remove the bulk of the recovered particulate matter. This flow stream is maintained at a sufficiently high rate to limit the steadystate build-up of solids in V-5. In a second circuit, cooling water is pumped through the cooler heat exchanger E-2 to remove the sensible and latent heat of the product gases.

\section{GASIFIER}

A side view of the indirect gasifier is shown in Figure 2-2. The gasifier consists of four tube fire-tube bundle that is immersed within the fluid bed. Fuel is burned inside a pulsating combustor that is refractory-lined and includes instrumentation for monitoring the temperature, static pressure, dynamic pressure, and flame status.

Flue gases exiting the combustor enter the four $1 \frac{1}{2}$-inch SS 310 fire tubes which extend upward through the fluid bed and into the freeboard region. The fire tubes exit into a 6 -inch flue gas plenum which is attached to an expansion bellows. The expansion bellows is connected to a 3 -inch exit pipe which is secured to the flange at the top of the freeboard via a coupling.

The bed section is constructed from an 8-inch SS 304 pipe and includes an injector port for feeding char. The bed expands to 12 inches in diameter at the interface to the freeboard where an overflow drain is provided. The freeboard is constructed from a 12 -inch SS 304 pipe.

Note that in prior tests conducted on biomass materials containing ash with particularly low-ash fusion points, a shielded tube arrangement was employed as shown in Figure 2-3. This shield arrangement reduced tube wall temperatures near the inlet specifically for the purpose of avoiding bed agglomeration. In the prior arrangement the fire tubes were formed in a U-tube configuration. This 


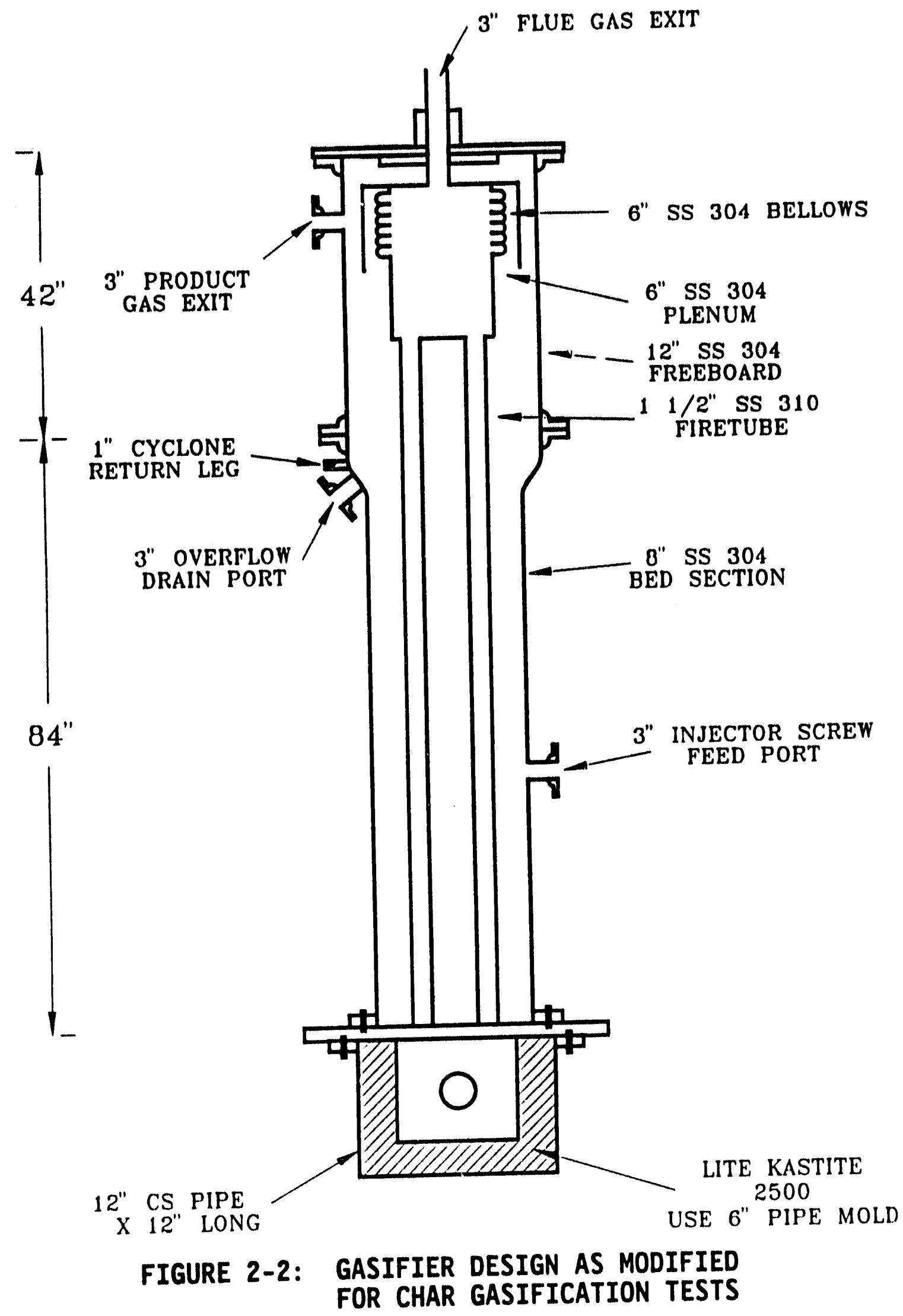




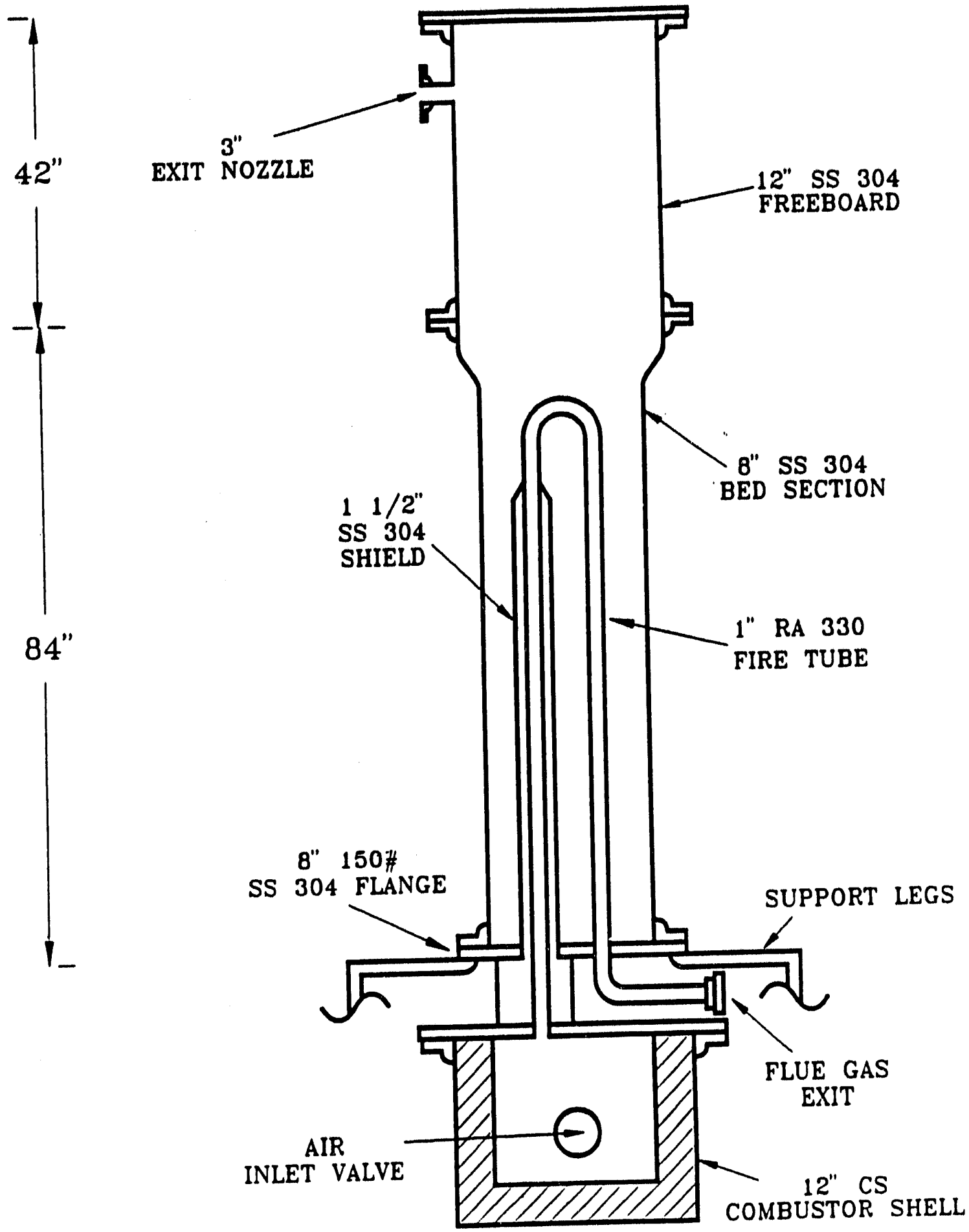
$\begin{array}{ll}\text { FIGURE 2-3: } & \text { ORIGINAL GASIFIER DESIGN FOR } \\ \text { REACTIVE BIOMASS FEEDSTOCKS }\end{array}$ 
avoided the need for bellows but complicated interface of the gasifier shell and combustor.

In the current program, the tests focused upon feedstocks with much higher ash fusion temperatures. Therefore, the use of radiation shields are unnecessary and only serve to limit achievable heat fluxes. A straight-through design to allow bolting the combustor directly to the base of the reactor without interference with flue gas exit ports has been substituted for the U-tube design.

\section{OPERATING METHODOLOGY}

The gasifier bed is initially fluidized using air or cryogenic nitrogen. Once fluidization is established, the pulse combustor is ignited. When the fluid bed temperature uniformly exceeds the steam saturation temperature, steam is substituted as the fiuidization medium.

When bed temperatures exceed $1200^{\circ} \mathrm{F}$, char feed is introduced into the bed. The gasifier temperature is then stabilized at the design test conditions. During the approach to steady-state, carbon char will accumulate within the bed and ultimately reach a constant value. Dry gas yield and composition are monitored using a product gas flow orifice meter and gas chromatograph to verify achievement of steady-state conditions. Test data are collected for a minimum two-hour period during the steady-state period as described below.

\section{IEST PROCEDURES}

Test data are collected at steady-state to evaluate the following performance parameters:

- Dry gas yield (SCF/Ib MAF char and \% of feed carbon)

- Dry gas composition

- Tar/oil yield (\% of feed carbon)

- Unconverted char yield (\% of feed carbon)

At the start of the steaoy-state period, the contents of the cyclone fines collection drum $\mathrm{V}-3$ is emptied and then replaced. Cyclone fines are then collected for a two-hour period. At the conclusion of the test run, the contents 
of collection drum $V-3$ is removed and weighed. A minimum of two solid grab samples are withdrawn and analyzed for carbon. The unconverted char in the cyclone catch is reported on a percent-carbon-in-feed basis.

In addition, the quench scrubber circulation flow is switched to a clean filter at the start of the steady-state period. At the conclusion of the test run, the filter is back-flushed into a receiving drum. The back flush liquid is weighed and sampled, dried and analyzed for carbon. The unconverted char in the quench catch is reported on a percent-carbon-in-feed basis. The particulate loading and carbon content of entrained solids downstream of cyclone $V-2$ are also checked intermittently using isokinetic probe methods.

During the steady-state operation, a gas sample is withdrawn downstream of cyclone V-2. The gas sample is cooled and condensed while the cumulative gas flow is measured using a positive displacement flow meter (wet test meter). The accumulated condensate is decanted to separate miscible and immiscible tar/oil fractions. Each fraction is analyzed for carbon content and reported on a percent feed basis.

Dry gas yield is monitored using an orifice flow meter located downstream of the quench scrubber/condenser. The dry gas yield is reported as standard cubic feet per pound MAF char feed. In addition, a nitrogen tracer is employed on an intermittent basis to confirm accuracy of the orifice measurement. A metered quantity of nitrogen is introduced into the dry gas stream. After a suffictent mixing length, the dry gas is sampled and analyzed in a gas chromatograph. The nicrogen flow rate and composition is used as a standard for calculating the dry gas yield.

There are two Microsensor Technology M200 gas chromatographs (GC) in use for gas analysis. Each GC is equipped with two capillary columns and two thermal conductivity detectors. The first $G C$ is equipped with a molecular sieve $5 A$ column and a Hayesep A column. This GC uses argon gas as a carrier. The socalled "permanent gases" (including hydrogen, oxygen, nitrogen, methane and carbon monoxide) are detected by the molecular sieve column. The other column, HayeSep $A$, is used to detect methane, carbon dioxide, ethylene and ethane. 
The second GC is equipped with a DB-5 column and a HayeSep A column. This GC uses helium as the carrier gas. Three hydrocarbons, 1.e., propane, 1so-butane and normal-butane, were identified on the DB-5 column before. Two sulfur compounds also appear on this column. They are sulfur dioxide and methyl mercaptan. On the HayeSep A column of this GC, carbon dioxide, ethylene, ethane, hydrogen sulfide, carbonyl sulfide, propylene and sulfur dioxide can be identified.

Therefore, different column conditions and sampling parameters were tested to find out the optimal conditions. All existing calibration gases (six in total) were tested in order to get a complete calibration table. Based on these tests, a set of methods was built for two M-200 GCs. These methods were tested by using the calibration gases and by running the real measurement during the coal pyrolysis test. They have proven suitable in the gas analysis for coal pyrolysis test.

It was found that the molecular steve column needs to be treated more carefully. The separations on this column often deteriorated by saturation of moisture or carbon dioxide in the test gas sample. Even passing the carrier gas through the column for several days without any test can result in bad separation. Therefore, some precautions have to be taken.

- Always re-condition the molecular sieve column before scheduled measurements.

- Lower the injection time to $5 \mathrm{~ms}$ to $1 \mathrm{imit}$ the effect of moisture and $\mathrm{CO}_{2}$ in the sample gases. (This measure has another reason: the linearality of quantitative analysis at low sampling amount.)

- If a long time test is needed, installing another molecular sieve column in the same GC is suggested.

The newly established GC methods were tested during the coal pyrolysis on June $8,1990$.

The coal pyrolysis creates many heavier hydrocarbons. More than 20 peaks appeared on the chromatogram from the DB-5 channel of the M200 GC. In order to identify and quantify these peaks, more standard calibration is needed. A gas mixture containing $n$-pentane, $n$-hexane, $n$-heptane, and toluene from Matheson Gas 
was purchased and a calibration was performed. This calibration enabled the GC to measure the amount of $n$-pentane, $n$-hexane, $n$-heptane and toluene.

In order to identify more compounds in the product gas of coal pyrolysis, more standard samples are needed. Two sets of hydrocarbon standard samples were purchased and the identification work is under progress.

There were two difficulties for quantitative analysis of sulfur compounds in the pyrolysis tests. It was found that many sulfur species exist in the product gas from pyrolysis or mild gasification. Many of these sulfur compounds cannot be completely separated from other hydrocarbons. For instance, although sulfur dioxide can easily be detected by the DB-5 column and HayeSep A column from the standard calibration gas, it is always difficult to be quantified in the test gas because of interference of water peak. Water and sulfur dioxide always co-elute on both DB-5 and HayeSep A column. Methyl mercaptan was interfered with n-butane. In order to perform satisfactory analysis of sulfur compounds, a GC specific to sulfur species was needed.

A new GC, Tracor Mode1 450, from Tracor Instruments, Austin, Texas, was ordered on May 18, 1990 and is scheduled to arrive by July 20th. The operation manual of the $450 \mathrm{GC}$ was received in advance so that the preparation for installation can be started earlier. The manual was studied and some materials needed for the installation of the new GC were ordered. This new instrument will be equipped with a 30-meter capillary column and a flame photometric detector (FPD). The FPD is a sulfur specific detector so that it will provide reliable analysis of sulfur compounds without interference from hydrocarbons. Besides, the FPD can also give the information of a flame ionization detector (FID) at the same time when it is used as flame photometric detector. Therefore, it provides information of both sulfur compounds and hydrocarbons simultaneously. In addition to the detector advantage, the longer capillary column and programmability of the new GC will bring much better separation for gas analysis.

A minimum of five gas analyses are performed over the steady-state duration. A schematic of the key sample collection points for the indirect gasification system are shown in Elqure 2-4. 


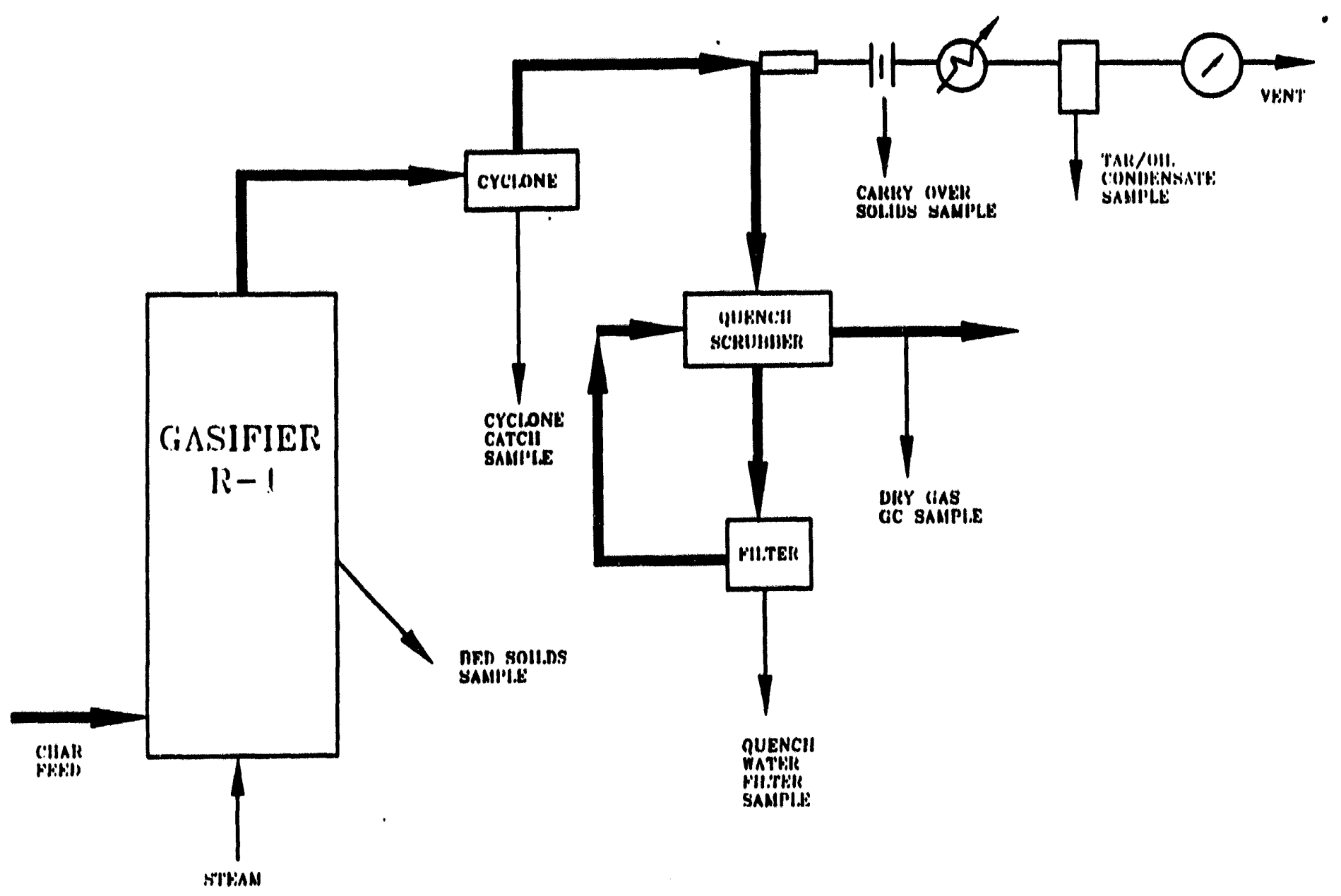

FIGURE 2-4: PRIMARY SAMPLE COLLECTION POINTS 


\section{Dry Gas Chromatograph Sample}

Gas chromatograph samples are withdrawn from the dry gas product down-st im of the particulate scrubber. Gas analysis includes $\mathrm{CO}, \mathrm{CO}_{2}, \mathrm{H}_{2}, \mathrm{CH}_{4}$ : and higher hydrocarbons at least through $\mathrm{C}_{3}$. In addition, sulfur speciation includes $\mathrm{H}_{2} \mathrm{~S}$, COS, $\mathrm{CH}_{3} \mathrm{SH}$, and $\mathrm{CH}_{3} \mathrm{SCH}_{3}$.

\section{Dry Gas Production Rate}

Dry gas production rate is monitored using two methods. First, an orifice meter is used to directly measure dry gas flow rate. Second, a tracer gas is introduced at a known flow rate into the dry gas stream and sampled via gas chromatography. Gas composition will be employed to indirectly calculate dry gas flow rate.

\section{Iar/011 Condensate Samole}

A wet gas sample is taken as a measured cumulative quantity using a wet test meter. The condensate collected during the sample period will be decanted to separate imiscible tar/oil. Both immiscible and miscible aqueous phases will be weighed and analyzed.

\section{Cyclone Catch Solids Samole}

Once steady-state is established, cyclone catch-solids are collected over a measured duration. The solids will be weighed and analyzed. Analysis of solids includes organic carbon, total sulfur, and ash content as a minimum.

\section{Bed Solids Sample}

Bed solids are sampled using a screw valve and analyzed. Analysis of solids includes organic carbon, total sulfur, and ash content as a minimum.

\section{Isokinetic Probe Carryover Solids Sample}

An isokinetic probe sample is withdrawn from the wet gas steam prior to the particulate scrubber. The gas draw rate is measured using a wet test meter. The gas stream is passed through a filter to capture entrained solids. The collected 
particulate matter is then weighed and analyzed. Analysis of soltds includes organic carbon, total sulfur, and ash content as a minimum.

\section{Material Balance Calculation}

The irflux of carbon and sulfur is calculated based on known char feed rate and composition. The efflux of carbon and sulfur is calculated based on measured compositions and mass rates for dry gas, cyclone catch, carry-over solids, and tar/oil condensate. The ratio of output to input for carbon and sulfur gives a measure of the material balance accuracy. These values will then be normalized to a 100 percent carbon material balance for the purpose of reporting dry gas, unconverted char, and tar/oil yields. This will be accomplished by dividing the component mass flows for each individual output stream by the ratio of total carbon measured for all output streams to carbon in the input feedstock.

\subsection{ANALYSIS METHODOLOGY}

A test plan matrix was prepared for experiments to be conducted on the MTCI indirect gasifier using feedstocks which include direct liquefaction residues, bituminous and subbituminous coals, and mild gasification chars. Five primary independent test variables were identified and are listed below:

- Feedstock type

- Gasifier temperature

- Gasifier throughput

- Steam-to-coal ratio

- Bed material

If we assume that the independent variables are each tested at two value levels, then the complete $2^{5}$ factorial matrix would required 32 separate test runs. As this exceeds the scope of the current investigation, a fractional factorial design has been selected based on the method of Plackett and Burman. (4) In this method, a reduced number of assemblies are selected from the complete factorial design in a specific manner which allows estimation of individual component effects with the maximum degree of statistical accuracy. 
The test plan consists of two identical Plackett-Burman matrices - one for each feedstock. The two feedstocks proposed for the test are a liquefaction ash concentrate obtained from the Wilsonville plant and a mild gasification char residue obtained from the Western Research institute in Laramie, Wyoming.

The Plackett-Burman two-level design matrix is shown in Iable_2-1. A $(+1)$ represents a high level for each independent variable, while a $(-1)$ represents a low level. The actual test values associated with each variable level are sunmarized in Iable 2-2. By application of Tables 2-1 and 2-2, the complete program test matrix is reconstructed as shown in Iable 2-3. Repeatability tests will be conducted for both ash concentrate and mild gasification char feedstocks as designated in tests $7 \mathrm{~A} / \mathrm{B}$ and $15 \mathrm{~A} / \mathrm{B}$. Note that the gasifier active volume (approximately $1.75 \mathrm{ft}^{3}$ ) has been used in conjunction with the design throughput $\left(1 \mathrm{~b} / \mathrm{hr}^{\left.-\mathrm{ft}^{3}\right)}\right.$ and steam-to-coal levels to calculate the actual coal and steam feed rates $(1 \mathrm{~b} / \mathrm{hr})$ for each test. It should be recognized that the order of testing may be modified for reasons of expediency.

TABLE 2-1:

Plackett-Burman Design Matrix

\begin{tabular}{cccccc} 
IEST NUMBER & $\begin{array}{c}\text { TEMPERATURE } \\
(\text { CF })\end{array}$ & & $\begin{array}{c}\text { STEAM/COAL } \\
\text { RATIO }\end{array}$ & $\begin{array}{c}\text { THROUGHPUT } \\
\left(1 \mathrm{~b} / \mathrm{hr} / \mathrm{ft}^{3}\right)\end{array}$ & $\begin{array}{c}\text { BED } \\
\text { MATERIAL }\end{array}$ \\
\cline { 2 - 3 } 1 & +1 & & +1 & +1 & -1 \\
2 & -1 & +1 & +1 & +1 \\
3 & -1 & -1 & +1 & +1 \\
4 & +1 & -1 & -1 & +1 \\
5 & -1 & +1 & -1 & -1 \\
6 & +1 & -1 & +1 & -1 \\
7 & +1 & +1 & -1 & +1 \\
8 & -1 & -1 & -1 & -1 \\
\hline
\end{tabular}




\title{
TABLE 2-2:
}

\section{VALUes OF HIGH and LOW LeVels for Independent VARIABLES IN PLACKETT-BURMAN DESIGN MATRIX}

\author{
INDEPENDENT VARIABLE \\ Temperature $\left({ }^{\circ} \mathrm{F}\right)$ \\ Steam/Coal Ratio (1b/1b) \\ Throughput $\left(\mathrm{Ib} / \mathrm{hr} / \mathrm{ft}^{3}\right)$ \\ Bed Material
}

HIGH LEVEL

$(+)$

LOW LEVEL

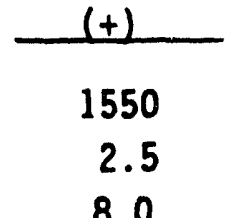

$(-1)$

1450

8.0

2.0

Limestone

6.0

Sand

TABLE 2-3:

Experimental Program Test Matrix 
The component effects for each independent variable are calculated with regard to the following dependent variables:

- Char yield

- Tar/oil yield

- Hydrogen yield

- Sulfur removal efficiency

Statistical methods are then used to evaluate the effect of each independent variable on each of the dependent variables listed above. A t-distribution approach is used to determine the statistical significance of each effect. Correlations using regression analysis will be derived when applicable. 


\section{SECTION 3.0}

\section{IEST AND ANALYSIS}

In preparation for the steam gasification tests, the existing process development unit (PDU) was refurbished and configured specifically for use in this program. The fabrication and installation of a shell and fire-tube bundle was completed. An existing pulse combustor (PC) was retrofitted to the PDU for the initial shakedown firing of the unit.

The pulse combustor comprises a conical design with an aerovalve located normal to the axis of the combustor. The pulse combustor is manually controlled and rated for a maximum firing rate of approximately $750,000 \mathrm{Btu} / \mathrm{hr}$. This unit was then replaced with a new pulse combustor containing a four-inch aerovalve after the initial shakedown tests were completed.

Efforts to obtain mild gasification char from the Western Research Institute were unsuccessful and without any other source of char available, the DOE expanded the scope of the project to include the production of mild gasification char in the MTCI reactor. AMOCO supported this increase in scope with a financial contribution in addition to their original participatory support. AMOCO also supported the acquisition of ash concentrate from the Wilsonville liquefaction plant for that series of steam gasification tests. The coal decided upon for the production of mild gasification char was a Black Thunder coal containing a low sodium fraction. The same coal was to be used by the Wilsonville liquefaction plant to provide the Critical Solvent Deashing (CSD) residue for the ash concentrate tests.

The initial shipment of ash concentrate from Wilsonville was composed of a significant fraction of fines that would have been unsuitable for the POU reactor. Further discussions with Wilsonville personnel indicated that the plant could be operated to produce a coarse ash concentrate that was eventually used in the gasification tests. 
Two separate shipments of low-sodium sub-bituminous coal were received. One shipment was from Black Thunder Bas in Coal Mine operated by ARCO and the other from AMAX's Eagle Butte Mine. The Eagle Butte Mine shipped a sample reject stream (nominally $\frac{1}{4} \times 0$ ) which needed no further crushing. The ARCO coal required crushing and screening. Both coals were from the Powder River Coal Basin, Anderson Seam (Wyodak coal bed), Campbell county, Wyoming. Coal and mineral matter analyses are shown in Table 3-1. The two coals are close with respect to chemical composition.

Iable 3-2 provides the sieve analysis of the Eagle Butte Mine coal as received and the Black Thunder Mine coal as prepared at MTCI. The laboratory unit produced a size distribution from the Black Thunder coal that could be used in the indirectly heated, fluid-bed gasifier.

\subsection{INITIAL SHAKEDOWN TESTS}

The reactor system was first pressure tested at 15 psig cold, and found to be well sealed. The old pulse combustor with a 2 -inch aerovalve was used for the initial shakedown tests, pending completion of a new one. The unit was test fired with limestone as the fluid-bed medium. The system was heated to about $350^{\circ} \mathrm{F}$ using air for fluidization before switching to steam to avoid steam condensation. The reactor bed heated up to $1350^{\circ} \mathrm{F}$ in less than one hour. At that temperature, calcination of 1 imestone began to take place. The bed temperature rise from $1350^{\circ} \mathrm{F}$ to $1500^{\circ} \mathrm{F}$ was completed in about 2 hours. The firing rate of the combustor was about $520,000 \mathrm{Btu} / \mathrm{hr}$. At this point, calcination of the startup 7 imestone bed appeared to be completed. Since $\mathrm{CO}_{2}$ is released during the calcination process, both the volume and weight of the bed material was reduced. Fresh 1 imestone was added at $60 \mathrm{lbs} / \mathrm{hr}$. The reactor reached a steady-state condition at $1550^{\circ} \mathrm{F}$. The steady-state fluidization velocity was $1.2 \mathrm{ft} / \mathrm{sec}$ with a steam flow rate of $68 \mathrm{lb} / \mathrm{hr}$ at $3 \mathrm{psig}$ back pressure in the system. The 1 imestone feed material had an average particle size of 600 microns and a minimum fluidization velocity of $0.8 \mathrm{ft} / \mathrm{sec}$.

In the next shakedown test, limestone with an average particle size of about 300 microns was used. In order to maintain a bed temperature of $1550^{\circ} \mathrm{F}$, $120 \mathrm{lb} / \mathrm{hr}$ of 1 imestone was added during this test. The feedstock contained a 
TABLE 3-1:

COAL AND MINERAL ANALYSIS

PROXIMATE ANALYSIS, WT.\%

Moisture

Ash

Volatile Matter

Fixed Carbon

HEATING VALUE, WT.\%

ULTIMATE ANALYSIS, WT.\%

Ash

Carbon

Hydrogen

Sulfur

Nitrogen

Oxygen

Chlorine

MINERAL ANALYSIS OF ASH (\%)

Phosphorus Pentoxide

Silicon Dioxide

Ferric Oxide

Aluminum Oxide

Titanium Dioxide

Manganese Dioxide

Calcium Oxide

Magnesium Oxide

Potassium Oxide

Sodium Oxide

Sulfur Trioxide

Barium Oxide

Strontium Oxide

Undetermined

TOTAL

\section{ADDITIONAL DATA}

Ibs $\mathrm{H}_{2} \mathrm{O}$ MMBtu

ibs Ash/MMBtu

Ibs Sulfur/MMBtu

Base/Acid Ratio

T250 ( $\mathrm{F}$ )

Silica Ratio

Slagging Type

Fouling Type

Percent Alkali as $\mathrm{Na}_{2} \mathrm{O}$
COAL MINES

\begin{tabular}{|c|c|c|c|}
\hline \multicolumn{2}{|c|}{ BLACK THUNDER } & \multicolumn{2}{|c|}{ EAGLE BUTTE } \\
\hline As-Rec'd & Dry & $A s-\operatorname{Rec} c^{\prime d}$ & Dry \\
\hline $\begin{array}{r}23.34 \\
5.48 \\
33.75 \\
37.43 \\
\end{array}$ & $\begin{array}{r}7 . \\
7.15 \\
44.03 \\
48.82 \\
\end{array}$ & $\begin{array}{r}29.08 \\
4.77 \\
30.76 \\
35.39 \\
\end{array}$ & $\begin{array}{r}6.72 \\
43.38 \\
49.90 \\
\end{array}$ \\
\hline 9312 & 12148 & 8454 & 11920 \\
\hline
\end{tabular}

7.15

69.66

5.03

0.46

0.92

16.78

$<0.01$

6.72

69.61

4.86

0.52

0.98

17.31

$<0.10$

BLACK THUNDER

EAGLE BUTTE

0.92

39.38

3.04

14.34

1.59

0.03

21.11

4.73

0.22

0.82

10.90

0.33

0.28

$\frac{2.31}{100.00}$

0.78

32.34

5.39

14.62

1.21

0.06

22.63

5.96

0.17

1.62

13.30

0.57

0.40

$\frac{0.95}{100.00}$

25.06

5.88

0.38

0.54

2291

57.69

Low

Medium

0.07
34.40

5.64

0.44

0.74

2172

48.76

Low

Severe

0.12 


\section{TABLE 3-2: \\ STEVE ANALYSTS OF WYOPAK COALS}

\begin{tabular}{|c|c|c|c|c|c|}
\hline \multirow{3}{*}{$\frac{\text { TYLER MESH }}{9+}$} & \multirow{3}{*}{$\begin{array}{l}\text { MICRONS } \\
2000\end{array}$} & \multirow{3}{*}{$\begin{array}{l}\text { INCHES } \\
0.078\end{array}$} & \multirow{3}{*}{$\begin{array}{l}\text { EAGLE BUTTE } \\
\frac{\text { As-Rec'd }}{29}\end{array}$} & \multirow{2}{*}{\multicolumn{2}{|c|}{$\begin{array}{l}\text { BLACK THUNDER } \\
\text { Crushed at MTCI }\end{array}$}} \\
\hline & & & & & \\
\hline & & & & 84 & 43 \\
\hline $12+$ & 1410 & 0.0555 & 17 & 4 & 13 \\
\hline $20+$ & 841 & 0.0328 & 19 & 4 & 15 \\
\hline $28+$ & 595 & 0.0234 & 8 & 2 & 6 \\
\hline $35+$ & 420 & 0.0164 & 7 & 2 & 6 \\
\hline 35- & $420 / 0$ & 0.0164 & $\frac{20}{100}$ & $\frac{2}{100}$ & $\frac{13}{100}$ \\
\hline
\end{tabular}

large proportion of fines, much of it being carried over to the cyclones and eventually to the venturi scrubber.

After the initial shakedown tests were completed, the new pulse burner with 1 arge aerovalve was installed and fired. The combustor had a higher firing rate and greater turndown capability, from about $800,000 \mathrm{Btu} / \mathrm{hr}$ to about 200,000 Btu/hr.

A third shakedown test was conducted. In this test the first stage cyclone catch was recycled back to the reactor. A firing rate of about $740,000 \mathrm{Btu} / \mathrm{hr}$ was maintained to keep the bed temperature at $1550^{\circ} \mathrm{F}$ while the limestone was added at a feed rate of $100 \mathrm{lb} / \mathrm{hr}$. All the components of the reactor system worked well with the first-stage cyclone in a recycle mode, the second-stage cyclone capturing additional fines and the venturi scrubber removing the remainder of the fines.

\subsection{MILD GASIFICATION CHAR PRODUCTION}

Three shakedown tests for mild gasification were completed, all with Black Thunder coal. The coal was fed at about $85 \mathrm{lbs} / \mathrm{hr}$ with $x y l e n e$ quench and nitrogen fluidization for about 5 and 6 hours each. The feed system worked predictably. The quench system required some modifications to minimize the loss 
of quench liquid from carryover to the incinerator. A droplet knockout in the incinerator line appeared to handle this adequately.

Finaliy, a char production test was run for 40 hours continuously using the Black Thunder coal at an average feed rate of about $90 \mathrm{lbs} / \mathrm{hr}$ (ranging from 60 to $120 \mathrm{lbs} / \mathrm{hr}$ ). The initial mass balance summary for the test is provided in Iable 3-3. The product gas analysis is given in Iable 3-4.

\subsection{MILD GASIFICATION DATA ANALYSIS}

A complete data analys is from Amoco Corporation was received for the liquid and solid samples of the mild gasification production run. The results of the chemical analysis are listed in Iables 3-5 through 3-8. Some of the samples of the mild gasification test were also sent to Core Laboratories. The data of chemical analysis from Amoco and Core Laboratories were compared. The results are presented in Iable 3-9. As can be seen from the table, the two sets of data are close to each other for most samples with a few being significantly different. For example, the oxygen content was much higher in the Amoco analysis. The discrepancy might have been caused by the analytical method. The percent oxygen content is usually calculated by difference of the total elements from 100 percent. The analytical error of each element can be summed up to give a significant error in the oxygen content. Another discrepancy is that the Amoco analysis gave lower moisture percentage for the feed material (Black Thunder coal). MTCI also did a moisture test that resulted in a similar number to the Amoco test. The coal sample sent to Core Laboratories was taken more than one and a half months before the mild gasification test and may have dried out during the period between Core Laboratories' sampling and the Amoco sampling. The analys is of cyclone catch data by the two laboratories are very close, indicating that the data are highly reliable.

To judge the discrepancies in the analytical results between Amoco and Core Laboratories, three solid samples were sent to a third-party laboratory. The samples were labeled as:

Sample \#1

Sample \#2

Sample \#3
073190 BTAI 2200 BS

080190 BTAI 2060 BS

080290 BTAI $9999 \mathrm{CL}$ 
TABLE 3-3:

\section{CHAR PRODUCTION TEST SUMMARY}

\section{IMPUI (llbs)}

Cosl:

Initial Bed

Total Feed (wet)

Dry Coal Feed

Moisture (24\%)

Xylene in Scrubber Tank Xylene Used

TOTAL

\section{QUTPUI (lbs)}

Char:

264

3552

2724

Bed After Run

146

Bed Overflow

Cyclone Catch

1300

828

255

400

Liquid and Tar Mixture 1313

Water Vapor in Prod. Gas Xylene Carried in Prod. Gas

Product Gas Generated

176

592

TOTAL

4362

Loss (unaccounted)

MEIGHT \& YIELD

$\begin{array}{lcc} & \text { Wet Basis } & \text { Dry Basis } \\ \text { Char } & 51.3 & 66.9 \\ \text { Dry Prod. Gas } & 16.7 & 21.7 \\ \text { Liquids (including losses) } & \underline{32.0} & \underline{11.4} \\ \text { TOTAL } & \underline{100} & \underline{100}\end{array}$




\section{TABLE 3-4:}

\section{PRODUCT GAS ANALYSIS}

\section{COMPONENTS}

$\mathrm{CH}_{4}$

$\mathrm{C}_{2} \mathrm{H}_{4}$

$\mathrm{C}_{2} \mathrm{H}_{6}$

$\mathrm{C}_{3} \mathrm{H}_{6}$

$\mathrm{C}_{3} \mathrm{H}_{8}$

$C_{4 \cdot n}$

$C_{5}$

$\mathrm{C}_{6}$

$c_{7}$

$\mathrm{CH}_{3} \mathrm{SH}$

$\cos$

Toluene

co

$\mathrm{CO}_{2}$

$\mathrm{H}_{2}$

$\mathrm{H}_{2} \mathrm{~S}$

$\mathrm{N}_{2}$

$\mathrm{H}_{2} \mathrm{O}$

Xylene

TOTAL
DRY

VOLLF

4.54

0.23

0.26

0.17

0.06

0.11

0.05

0.06

0.01

0.01

0.01

0.03

1.31

3.69

5.32

0.03

74.85

0.00

0.92

91.66
$\mathrm{N}_{2}$-FREE

VOL. $\%$

28.57

1.45

1.64

1.07

0.38

0.69

0.32

0.38

0.06

0.06

0.06

0.19

8.24

23.22

33.48

0.19

0.00

0.00

0.00

100.00
$1 \mathrm{bm} / \mathrm{hr}$

3.42

0.30

0.37

0.34

0.12

0.30

0.17

0.24

0.05

0.02

0.03

0.13

1.72

7.62

0.50

0.05

98.44

5.03

4.58

123.43 
TABLE 3-5:

ANALYSES OF SOLID SAMPLES FROM

BLACK THUNDER COAL PYROLYSIS AT MTCI

\section{SAMPLLE NUMBER \\ 080290BTA 13:37 \\ Overflow Catch \\ 080290BTA/13:37 \\ Cyclone Catch \\ BLACK THUNDER}

FEED

073190BTA/15:00

CL

073190BTA $/ 14: 28$

BS

073190BTA $/ 18: 40$

BS

073190BTA/22:00

BS

080190BTA/04:00

BS

080190BTA/09: 35

BS

O80190BTA/ $13: 30$

BS

080190BTA $/ 19: 30$

BS

080190BTA $/ 22: 00$

BS

BS

080290/14:00

VSCF Filter Cake
080290BTA $/ 04: 00$

\&C \&H \&N \&S \&O

$\begin{array}{lll}73.75 & 1.43 \quad 0.81\end{array}$

$0.46 \quad 13.89$

0.58

$\begin{array}{lll}80.63 \quad 2.09 & 1.01\end{array}$

$57.41 \quad 5.35$

0.75

0.53

30.79

14.35

36.58

5.17

60.77

1.47

$<0.5$

0.35

14.44

1.14

29.45

22.97

27.15

$<0.5$

$<0.5$

$0.21 \quad 46.65$

2.24

25.53

25.99

$\begin{array}{llllllll}41.85 & 0.96 & <0.5 & 0.30 & 48.96 & 1.10 & 10.31 & 7.93\end{array}$

$54.93 \quad 0.92<0.5$

0.13

33.29

0.64

11.44

10.73

$54.96 \quad 1.12<0.5$

0.38

32.72

1.32

$10.63 \quad 10.82$

49.65

0.66

$<0.5$

$0.28 \quad 39.84$

0.67

9.22

9.57

$63.58 \quad 1.04<0.5$

0.50

24.97

1.51

8.95

9.91

$84.42 \quad 1.61$

0.63

0.50

3.13

0.94

11.00

9.71

$64.32 \quad 1.33<0.5$

0.43

23.20

1.85

9.94

10.72

$81.88 \quad 1.81$

0.89

0.40

6.30

0.70

9.37

8.72

NOTE: ETemental analyses are reported on an as-received bas is

(includes moisture) with oxygen calculated by difference. 
TABLE 3-6:

ANALYSES OF LIQUID SAMPLES FROM

BLACK THUNDER COAL PYROLYSSTS AT MTCI

INCINERATOR SCRUBBER WATER:

SAMPLE NUMBER

073190/14:34 ISW

073190/17:35 ISW

080190/15:35 ISW
IOTAL ORGANIC CARBON

$44 \mathrm{mg} / 11$ ter

$92 \mathrm{mg} / 1 \mathrm{iter}$

$221 \mathrm{mg} / 1$ iter
IOTAL SUSPENDED SOLIDS

$<5 \mathrm{mg} / \mathrm{liter}$

$5 \mathrm{mg} / 1$ tter

$734 \mathrm{mg} / 1$ iter

CONDENSATE SAMPLE DISTILLATIONS:

SAMPLE NUMBEB

073190/14:30 VSWBF

073190/14:32 VSWAF

073190/17:30 VSWBF

073190/17:32 VSWAF

080190/14:03 VSWBF

080190/14:03 VSWAF

080290/09:08 VS

(1 of 2)

080290/09:08 VS

(2 of 2)

$080290 / 13: 30$ VS

$$
\text { IEMP RANGE (०C) }
$$

$137 \cdot 145$

$137 \cdot 145$

$137 \cdot 145$

125

$98 \cdot 134$

$98-105$

$101-125$

$101 \cdot 125$
Y OVERHEAD

93.4

94.3

91.6

$91.3^{*}$

96.1

97.4

92.2

97.2

19.1

- Values are estimated. 
TABLE 3-7:

ANALYSES OF COMPOSITE LIQUID SAMPLES FROM

BLACK THUNDER COAL PYROLYSIS AT MTCI

$\frac{\text { LIGHTLLOUID }}{(\%)} \quad \frac{\text { HEAVY LIOUID }}{(\%)} \quad \frac{\text { WHOLE }}{(\%)}$

PERCENT OF WHOLE CONDENSATE

50.8

48.2

100.0

$I B P-110^{\circ} \mathrm{C}$

97.9

31.8

65.4

$150^{\circ} \mathrm{C}+$

TOTAL

2.1

.68 .2

34.6

100.0

100.0

100.0

WATER

97.9

22.9

61.0

XYLENE

0.0

9.0

4.4

COAL LIQUID

1.3

40.4

20.5

COAL CHAR

0.8

22.7

14.1

TOTAL

100.0

100.0

100.0

Property of AMOCO 011 Company.

Proprietary - To Be Maintained in Confidence. 
TABLE 3-8:

ESTIMATES OF COAL LIQUID QUALITY BASED ON

ANALYSTS OF HEAVY LTOUID 150 C + ERACTION

\section{ELEMENTAL ANALYSES:}

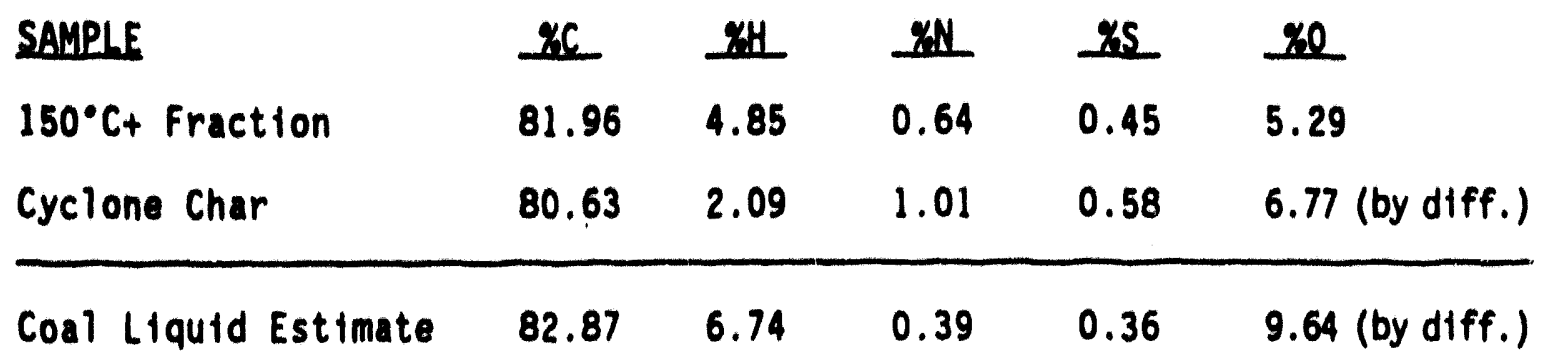

SIMULATED DISTILLAIION BY GC:

\begin{tabular}{cc} 
WEIGHI\% & IEMPERATURE $(\cdot F)$ \\
\hline 5 & 497 \\
10 & 532 \\
20 & 588 \\
30 & 652 \\
40 & 713 \\
50 & 787 \\
60 & 875 \\
70 & 980 \\
80 & 1099 \\
90 & 1233 \\
95 & 1301
\end{tabular}

Property of AMOCO 011 Company.

Proprietary - To Be Maintained In Confidence. 
TABLE 3-9:

\section{COMPARISON OF THE CHEMICAL ANALYSIS DATA} EROM AMOCO AND CORE LABORATORIES

$\begin{array}{lllllllllll} & \mathrm{C} & \mathrm{H} & \mathrm{N} & \mathrm{S} & \mathrm{O} & \mathrm{H} 20 & \text { UM } & \text { ASH } \\ \text { BI COALFEED } & \text { AMOCO } & 57.41 & 5.35 & 0.75 & 0.53 & 30.79 & 14.35 & 36.58 & 5.17 \\ \text { Core Labs } & 53.40 & 3.86 & 0.70 & 0.35 & 12.87 & 23.34 & 33.75 & 5.48\end{array}$

BED SAMPLES

$\begin{array}{llllrrrrrr}\text { 073190BTA2200BS } & \text { AMOCO } & 54.93 & 0.92 & <0.50 & 0.13 & 33.29 & 0.64 & 11.44 & 10.73 \\ & \text { Core Labs } & 64.76 & 1.52 & 0.90 & 0.16 & 9.70 & 0.59 & 21.27 & 22.37 \\ \text { 080190BTA0400BS } & \text { AMOCO } & 54.96 & 1.12 & <0.50 & 0.38 & 32.72 & 1.32 & 10.63 & 10.82 \\ & \text { Core Labs } & 80.65 & 2.00 & 0.93 & 0.33 & 2.98 & 2.21 & 11.37 & 10.90\end{array}$

$\begin{array}{llllllllll}\text { CYCLONE CATCH AMOCO } & 80.63 & 2.09 & 1.01 & 0.58 & 6.77 & 0.71 & 12.10 & 8.92 \\ & \text { CORE Labs } & 81.83 & 2.00 & 1.10 & 0.37 & 3.50 & 0.80 & 11.31 & 10.40\end{array}$

$\begin{array}{llllllllll}\text { EILIER CAKE } & \text { AMOCO } & 58.40 & 5.87 & 0.63 & 0.40 & 28.03 & 23.63 & 27.29 & 6.67 \\ & \text { Core Labs } & 27.14 & (\text { Total } & \text { Organic C) } & & 67.06 & & \end{array}$ 
Sample 1 and Sample 3 were taken from the same batch as was sampled for Amoco and Core Labs. Sample 2 was a mixture of two bed samples taken at 2:00 a.m. and 6:00 a.m. on August 1, 1990, in place of the bed sample of 4:00 a.m., August 1, 1990, which was analyzed by Amoco and Core Labs.

The laboratory that carried out the confirmation analysis of the samples of the mild gasification test was Desert Analytics of Tucson, Arizona. The results of analysis are listed in Iable 3-10 together with the results from Amoco and Core Laboratories for comparison. For element analys is of carbon, hydrogen and nitrogen, Desert Analytics' results are closer to that of Core Labs. Desert Analytics gives a much lower concentration in sulfur analys is than both Amoco and Core Labs. The oxygen analysis of Desert Analytics falls in between that of other two laboratories. Desert Analytics uses an independent method to measure oxygen in the sample instead of calculating the difference of the sum of other elements from 100 percent as the other two laboratories do. In general, Core Labs and Desert Analytics each have closer analytical results. This may indicate that their results have a slightly higher reliability, but the difference in analysis by the three labs is still apparent.

Based upon the analytical results from AMOCO and Core, and the product gas analysis in Table 3-4, a material balance was calculated and is presented in Iable 3-11. The analytical results of Amoco were used for the calculation. Compared with the earlier material balance, two major changes were made. First, at the INPUT side, the water originally in the venturi scrubber tank was included. Second, the 400 pounds of xylene used for cleaning the venturi scrubber system was excluded from the balance because it was not involved in the gasification process and was not included in the sample sent to Amoco for analysis. Correspondingly, this amount was subtracted from the VS (venturi scrubber) mixture, which was presented as "liquid and tar mixture" in the critical analysis. The losses on the wet, dry and MAF basis are 4.2 percent, 8.3 percent and 7.6 percent, respectively. The loss based on wet materials is smaller than that for the dry and MAF basis, apparentiy because the water in the product gas was overestimated. The water in the gas phase was calculated by using its saturated 


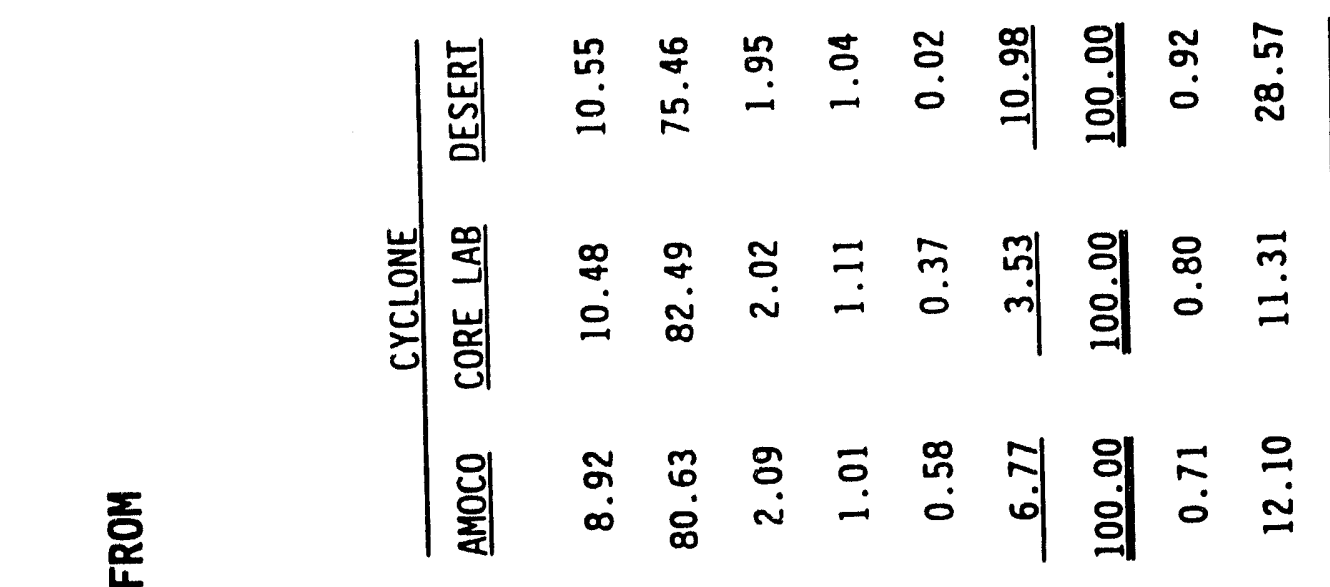

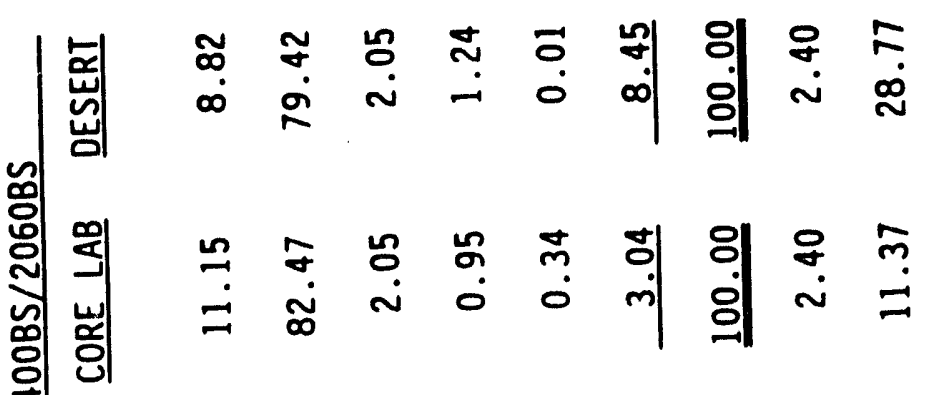

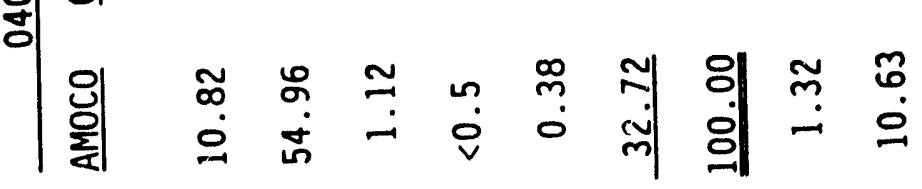

$$
\begin{aligned}
& \text { 岌山 } \\
& \text { 㫐号 } \\
& \text { 뭊울 } \\
& \text { 옹 }
\end{aligned}
$$

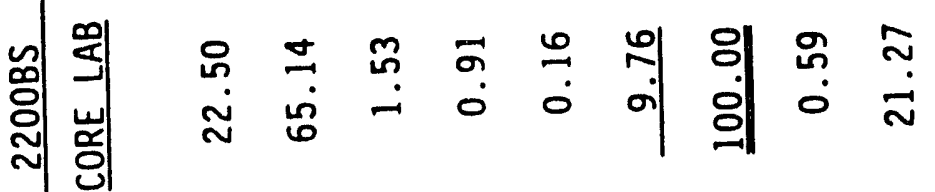

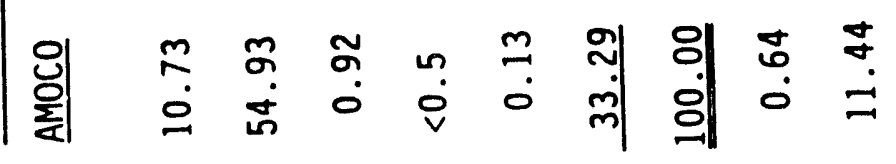

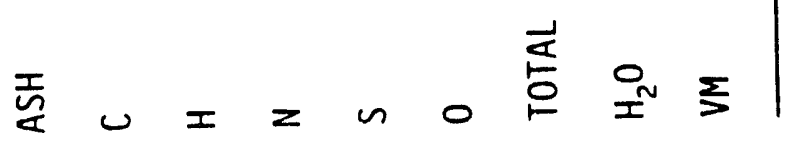


TABLE 3-11:

\section{OVERALL MATERIAL BALANCE}

INPUT (Ibs)

OUTPUT (1bs)

\begin{tabular}{|c|c|c|c|c|c|c|c|}
\hline & $\begin{array}{c}\text { As } \\
\text { Rec'd }^{\prime}\end{array}$ & Dry & MAF & & $\begin{array}{l}\text { As } \\
\text { Rec'd }\end{array}$ & Dry & MAF \\
\hline Bed Original & 264 & 258 & 189 & Bed Final & 146 & 145 & 132 \\
\hline Feed Coal & 3552 & 3042 & 2859 & Overflow & 640 & 634 & 572 \\
\hline Water in Scrubber & 130 & & & Cyclone Catch & 1300 & 1291 & 1175 \\
\hline xylene in Scrubber & 255 & & & Filter Cake & 65 & 50 & 45 \\
\hline \multirow[t]{4}{*}{ TOTAL } & \multirow[t]{4}{*}{4201} & \multirow[t]{4}{*}{3300} & \multirow[t]{4}{*}{3048} & Dry Product Gas & 592 & 592 & 592 \\
\hline & & & & $\mathrm{H} 2 \mathrm{O}$ in Gas & 194 & & \\
\hline & & & & xylene in Gas & 176 & & \\
\hline & & & & TOTAL & 4026 & 3027 & 2816 \\
\hline
\end{tabular}


vapor pressure. Under the condition of the mild gasification run, the water vapor pressure in the venturi scrubber could have been much lower than the standard vapor pressure. The over-estimation of water in the product gas results in a higher output, hence, the smaller loss of total materials on the wet basis.

The loss of materials could be caused by three factors. First, there were leaks and spills during the test. Second, some systematic error of measurement and analysis might exist and cause some negative error in the output which would appear as loss of materials. Lastly, the char and coal liquid washed out by the 400 pounds of $x y l$ lene were not counted for in the material balance. Although the wash liquid may not contain very much product material, the amount might still be of considerable significance.

The yields of char, liquid and gas product based on dry and MAF feed are listed in Table 3-12. The normalized yield of char was 69.9 percent, gas yield was 22.9 percent, and the coal 1 iquid was 7.2 percent. These yields are typical of yields obtained by Merriam \& Cha(2) at temperatures between $1140^{\circ} \mathrm{F}$ to $1220^{\circ} \mathrm{F}$. The carbon balance is presented in Table 3-13. In carrying the carbon balance, the percent carbon in the original bed was calculated as follows: Since the earliest available bed sample was 07190BTA/14:28 BS, the carbon content of this sample was chosen for the original bed carbon. But the number given by the Amoco analysis (27.15\%, see Table 3-5), seemed too low. The carbon percent was renormalized based on the assumption that the initial bed consisted of char and limestone only, and the ash content given by the Amoco analysis was correct. Ten percent of ash in the char was assumed to calculate the carbon percentage in the bed sample of 073190BTA/14:28 BS. This method resulted in a carbon content of 56.4 percent that was used in Table 3-13. The carbon balance is very good at 101 percent. A carbon balance of 101 percent may be the result of errors of measurement of the materials or errors in the analysis of carbon percentage.

The data collected during the 40-hr continuous mild gasification test are plotted in Figures 3-1 through 3-3. Al so included is Figure 3-4 which shows the comparative effectiveness of $x y l$ ene and water quenching of the pyrolysis vapors. With reference to Figure 3-3, the wide fluctuations in the temperature are due 
TABLE 3-12:

PERCENT YIELD OF PRODUCTS

\begin{tabular}{|c|c|c|c|c|c|c|}
\hline & $\frac{\text { DRY MASS }}{(1 \mathrm{~b})}$ & $\begin{array}{l}\text { PERCENT } \\
\frac{\text { YIELD }}{(\%)}\end{array}$ & $\frac{\text { NORMALIZED }}{(\%)}$ & $\frac{\text { MAF MASS }}{(1 \mathrm{~b})}$ & $\begin{array}{l}\text { PERCENT } \\
\text { YIELD } \\
(\%)\end{array}$ & $\frac{\text { NORMALIZED }}{(\%)}$ \\
\hline COAL FEED & 3042 & & & 2859 & & \\
\hline CHAR & 1986 & 65.29 & 71.83 & 1807 & 63.20 & 69.88 \\
\hline LIQUID & 187 & 6.15 & 6.76 & 187 & 6.54 & 7.23 \\
\hline GAS & 592 & 19.46 & 21.41 & 592 & 20.71 & 22.89 \\
\hline TOTAL & 2765 & 90.89 & 100.00 & 2586 & 90.45 & 100.00 \\
\hline
\end{tabular}

TABLE 3-13:

CARBON BALANCE

INPUT

OUTPUT

\begin{tabular}{|c|c|c|c|c|c|c|c|}
\hline & $\begin{array}{l}\text { Weight } \\
\text { (los) }\end{array}$ & $\begin{array}{l}\text { Percent } \\
\text { Carbon } \\
(\%) \\
\end{array}$ & $\begin{array}{l}\text { Mass of } \\
\text { Carbon } \\
(1 \mathrm{bm})\end{array}$ & & $\begin{array}{l}\text { Weight } \\
\text { (los) }\end{array}$ & $\begin{array}{c}\text { Percent } \\
\text { Carbon } \\
(\%) \\
\end{array}$ & $\begin{array}{l}\text { Mass of } \\
\text { Carbon } \\
(1 \mathrm{bm})\end{array}$ \\
\hline Bed Original & 264 & 56.4 & 149 & Bed Final & 146 & 81.88 & 120 \\
\hline Feed Coal & 3552 & 57.41 & 2039 & Overflow & 640 & 73.75 & 472 \\
\hline \multirow{5}{*}{ TOTAL } & \multirow{5}{*}{3816} & & \multirow{5}{*}{2188} & Cyclone Catch & 1300 & 80.63 & 1048 \\
\hline & & & & Filter Cake & 65 & 58.4 & 38 \\
\hline & & & & vs Mixture & 913 & 28.36 & 259 \\
\hline & & & & Dry Product Gas & 592 & 46.07 & 273 \\
\hline & & & & $\begin{array}{l}\text { TOTAL } \\
\text { Percent Yield (5 }\end{array}$ & )$^{4026}$ & & $10 \frac{2209}{0.97}$ \\
\hline
\end{tabular}




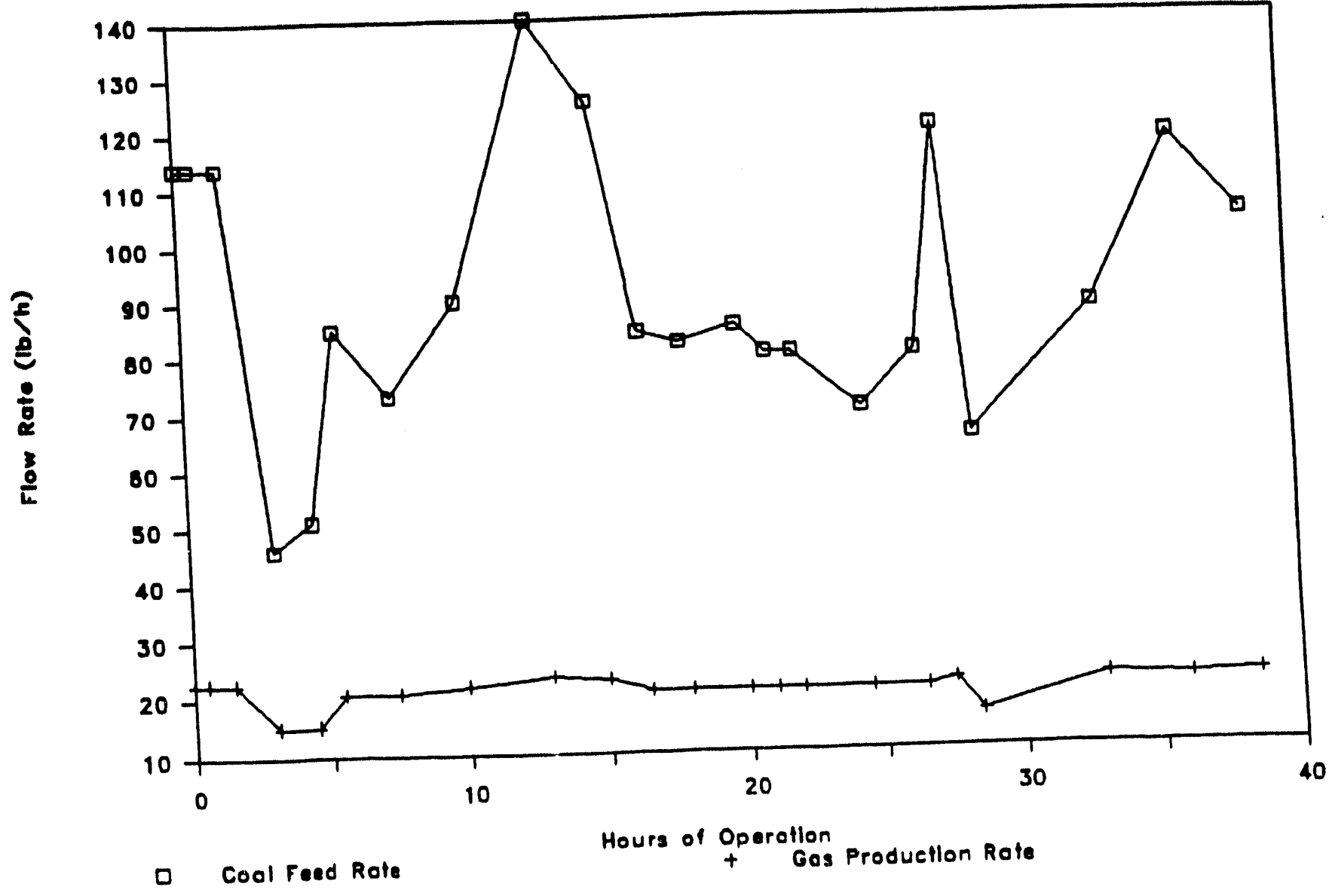

FIGURE 3-1: COAL FEED AND GAS PRODUCTION VS. TIME
MILD GASIFICATION PRODUCTION RUN 


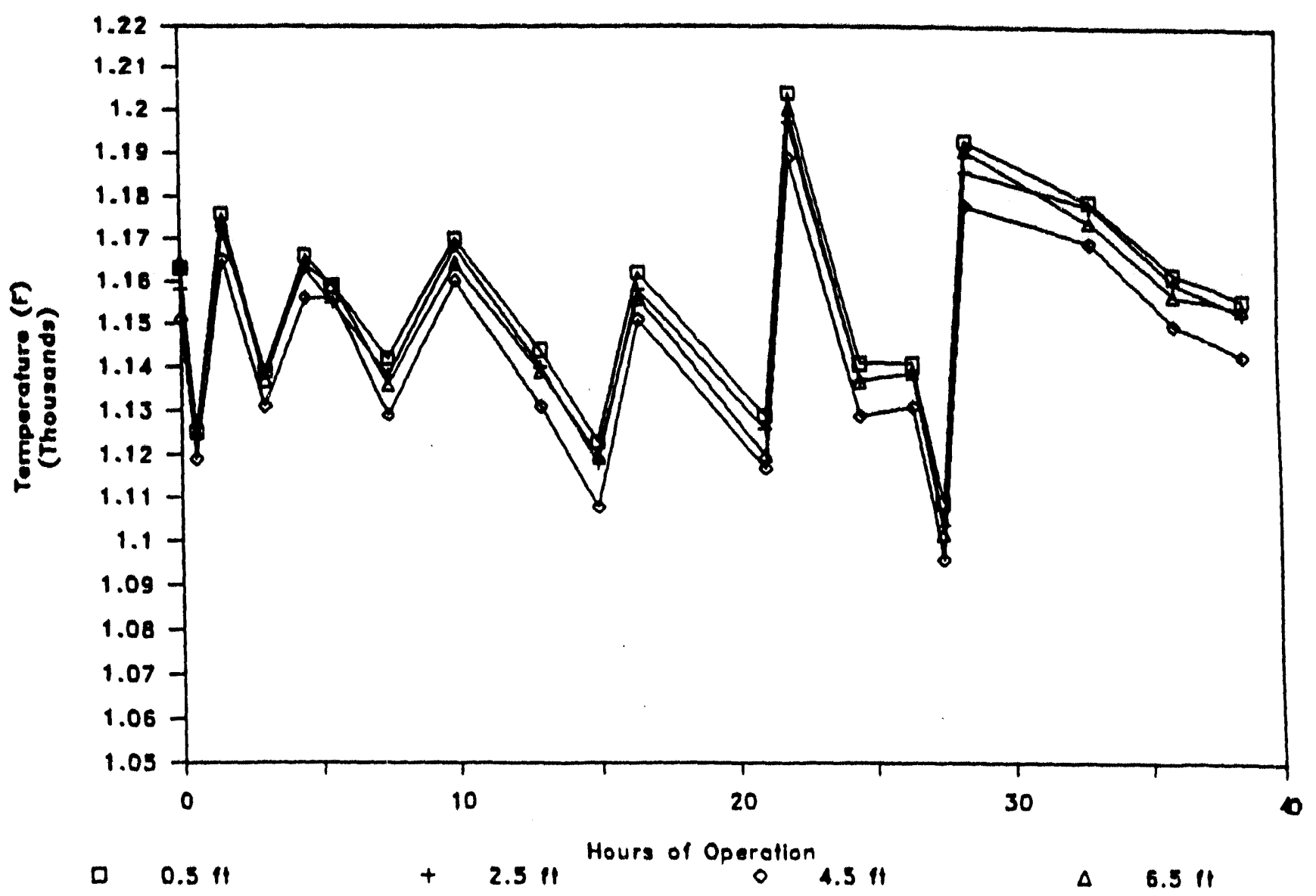

FIGURE 3-2: REACTOR BED TEMPERATURE VS. TIME MILD GASIFICATION PRODUCTION RUN 


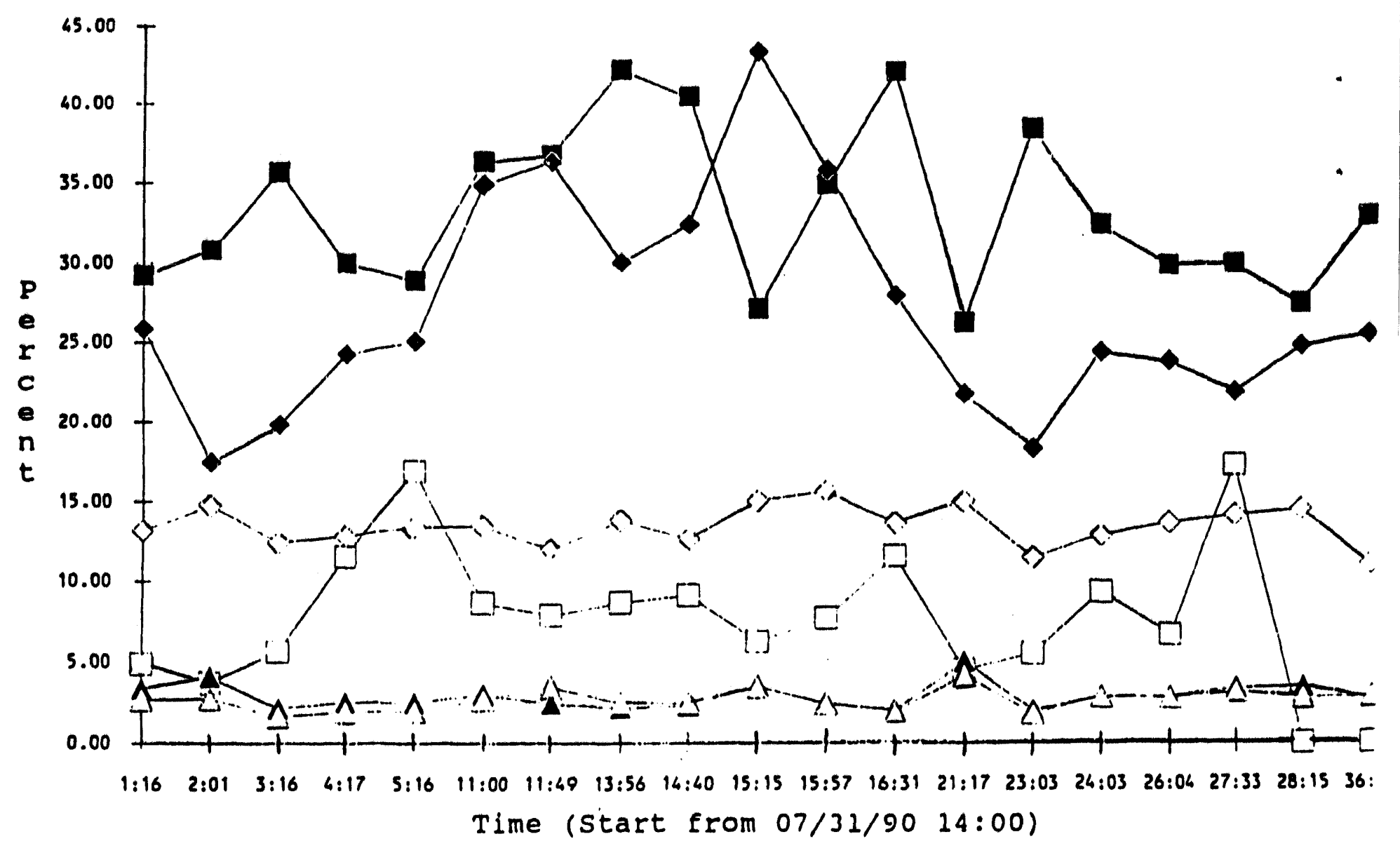

\begin{tabular}{|l|}
\hline Mydrogen \\
$\square \mathrm{co}$ \\
$\Delta_{\mathrm{CO} 2}$ \\
$\Delta_{\text {Methane }}$ \\
$\Delta \mathrm{C2}$ \\
$\triangle \mathrm{C3}$
\end{tabular}

FIGURE 3-3: PRODUCT GAS COMPOSITION MILD 
(DB-5 Col; TCD)
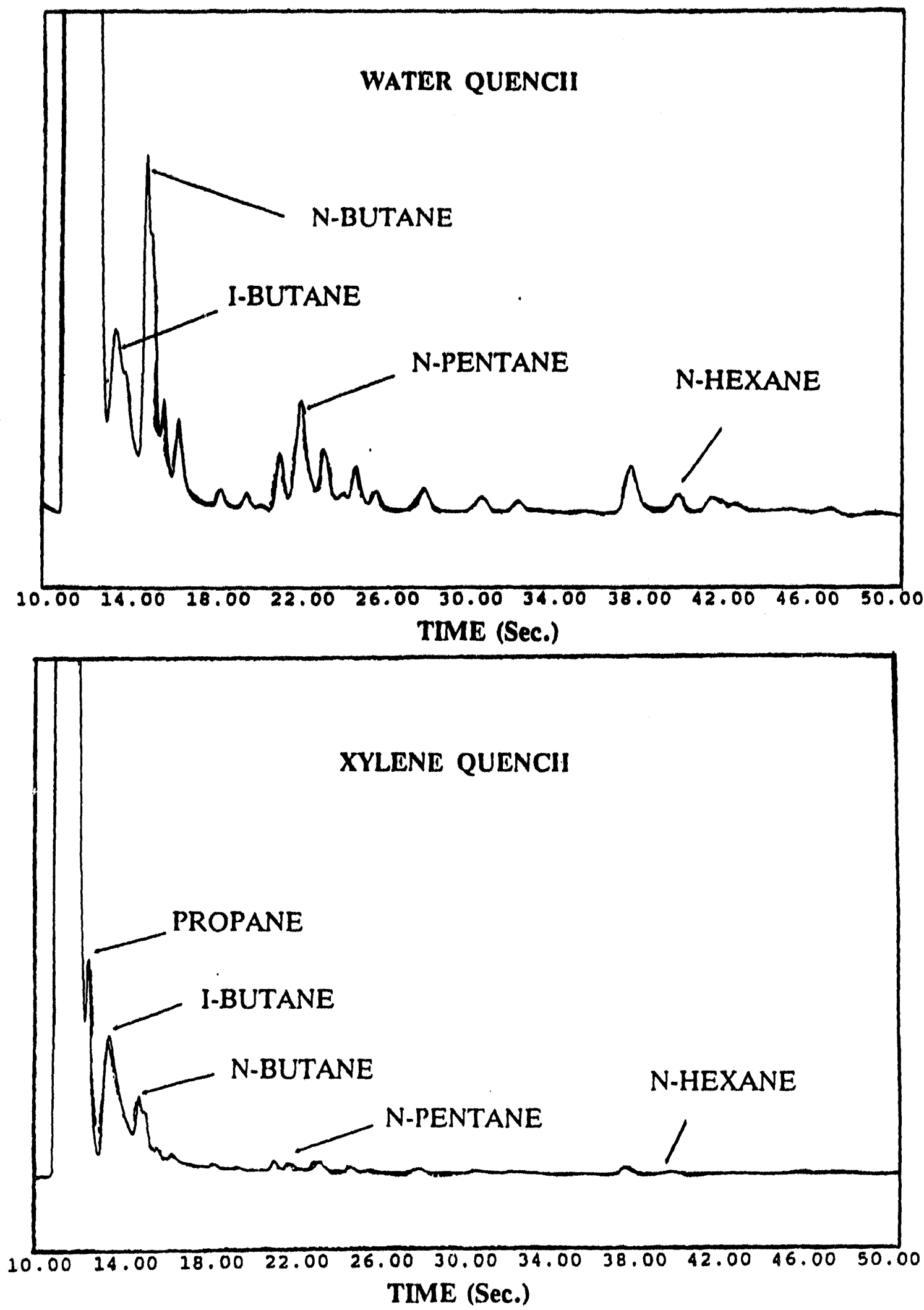

FIGURE 3-4: CHROMATOGRAPHS OF PRODUCT GAS MILD GASIFICATION PRODUCTION RUN 
not only to the variations in the coal feed rate, but also because of the unpredictable behavior of the feeder discussed earlier.

\subsection{MILD CHAR GASIFICATION}

Three tests were conducted for gasifying the char produced in the MTCI reactor. The tests were run under varying operating conditions and a total of about 600 pounds of char was gasified.

During the first test, only char was used as the flutdizing bed, operating at an average temperature of $1490^{\circ} \mathrm{F}$. The test was aborted after two hours due to a feeder problem. The char feed rate was very high $(-75 \mathrm{lb} / \mathrm{hr})$ and could not be reduced as the feeder was designed to feed coarse blomass materials and not relatively fine char. A large portion of the char was therefore collected in the cyclones and also carried over to the scrubber system. The feeder was modified by inserting a constriction plate inside the hopper such that feed rates of 10 to $40 \mathrm{lbs} / \mathrm{hr}$ could be achieved.

For the second test, a mixture of 1 imestone and char was used as the fluidized bed medium. The test was conducted for three different char feed rates. While the test run was quite smooth for the first two feed rates of 20 and 30 $\mathrm{lbs} / \mathrm{hr}$, some problems were accounted near the end of the run for the third feed rate of $40 \mathrm{lbs} / \mathrm{hr}$. At $1475^{\circ} \mathrm{F}$, the limestone bed began to calcine and elutriate.

The third test used a sand bed with feed rates of 20 and $30 \mathrm{lbs} / \mathrm{hr}$. For the $30 \mathrm{lb} / \mathrm{hr}$ feed rate, the test was conducted at two different temperatures, $1465^{\circ} \mathrm{F}$ and $1500^{\circ} \mathrm{F}$. No problems were encountered during this test.

The product gas and mass balance analyses are tabulated in Iables 3-14 through $3-18$. For the last two successful tests, the rates of gas production and variations of bed temperatures are al so shown in Eigures 3-5 through 3-10. It should be noted here that the sudden decrease in the gas production rate for the second test was due to a corresponding decrease in the bed temperature. 
TABLE 3-14:

PRODUCT GAS ANALYSTS FROM CHAR GASIFICATION (TEST 1)

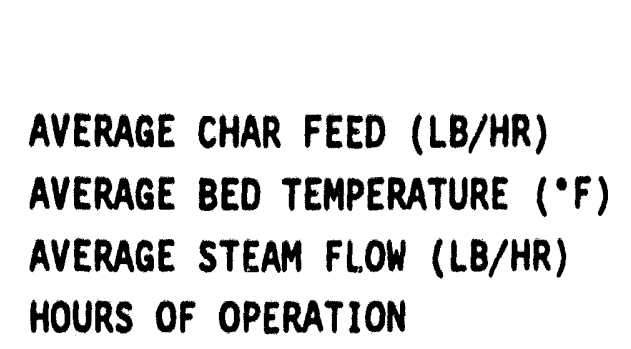

GAS COMPONENTS

$\mathrm{H}_{2}$

$\mathrm{N}_{2}$

CO

$\mathrm{CO}_{2}$

$\mathrm{CH}_{4}$

$\mathrm{C}_{2} \mathrm{H}_{4}$

$\mathrm{H}_{2} \mathrm{~S}$

TOTAL
OPERATING CONDITION II

\begin{tabular}{|c|c|c|}
\hline & 75 & \\
\hline & 1492 & \\
\hline & 69.15 & \\
\hline & 2 & \\
\hline $\begin{array}{c}\text { DRY } \\
\text { VOL. } \%\end{array}$ & $\begin{array}{l}N_{2} \text {-free } \\
\mathrm{YO}_{L} . \% \\
\end{array}$ & $\begin{array}{l}\text { FLOW RATE } \\
(1 \mathrm{~b} / \mathrm{hr})\end{array}$ \\
\hline 40.92 & 46.98 & 8.48 \\
\hline 2.94 & 0.00 & 9.54 \\
\hline 32.50 & 37.31 & 94.64 \\
\hline 12.16 & 13.96 & 55.45 \\
\hline 1.51 & 1.73 & 2.54 \\
\hline 0.00 & 0.00 & 0.00 \\
\hline 0.02 & 0.02 & 0.06 \\
\hline 90.04 & 100.00 & 170.70 \\
\hline
\end{tabular}


TABLE 3-15:

\section{PRODUCT GAS ANALYSTS FROM CHAR GASIEICATION}

(TEST 2)

\begin{tabular}{|c|c|c|c|c|c|c|c|}
\hline & & & $\begin{array}{l}\text { OPERATING } \\
\text { CONDITION } 11\end{array}$ & & $\begin{array}{l}\text { ERATING } \\
\text { DITION }\end{array}$ & $\begin{array}{l}\text { OVER } \\
\text { AVER }\end{array}$ & \\
\hline AVERAGE CHA & EED (1t & & 20 & & 30 & 2 & \\
\hline AVERAGE BED & IMPERATI & $E\left({ }^{\circ} F\right)$ & 1450 & & 1462 & 145 & \\
\hline AVERAGE STE & FLOW ( & (hr) & 56.31 & & 9.79 & 53.4 & \\
\hline HOURS OF OP & ATION & & 4.5 & & 3.5 & & \\
\hline $\begin{array}{l}\text { GAS } \\
\text { COMPONENTS }\end{array}$ & $\begin{array}{l}\text { DRY } \\
\text { VOLLY }\end{array}$ & $\begin{array}{l}\text { N2 - FREE } \\
\text { YOL K }\end{array}$ & $\begin{array}{l}\text { FLOW RATE } \\
(1 \mathrm{~b} / \mathrm{hr})\end{array}$ & $\begin{array}{l}\text { DRY } \\
\text { VOL.\% }\end{array}$ & $\begin{array}{l}\text { N2-FREE } \\
\text { YOL.\% }\end{array}$ & $\begin{array}{l}\text { FLOW RATE } \\
(1 \mathrm{~b} / \mathrm{hr})\end{array}$ & $\begin{array}{c}\text { GAS } \\
\text { FLOW RATE } \\
\text { (lb/hr) }\end{array}$ \\
\hline $\mathrm{H}_{2}$ & 48.40 & 51.86 & 3.92 & 52.47 & 55.19 & 3.80 & 3.87 \\
\hline $\mathrm{N}_{2}$ & 8.07 & 0.00 & 9.70 & 9.56 & 0.00 & 9.91 & 9.79 \\
\hline CO & 20.85 & 22.34 & 23.38 & 19.86 & 20.89 & 20.05 & 21.92 \\
\hline $\mathrm{CO}_{2}$ & 23.14 & 24.79 & 40.92 & 21.06 & 22.15 & 33.33 & 37.60 \\
\hline $\mathrm{CH}_{4}$ & 0.90 & 0.97 & 0.58 & 1.63 & 1.72 & 0.99 & 0.76 \\
\hline $\mathrm{H}_{2} \mathrm{~S}$ & 0.04 & 0.04 & 0.05 & 0.05 & 0.05 & 0.06 & 0.05 \\
\hline TOTAL & 101.40 & 100.00 & 78.55 & 104.65 & 100.00 & 68.14 & 74.00 \\
\hline
\end{tabular}




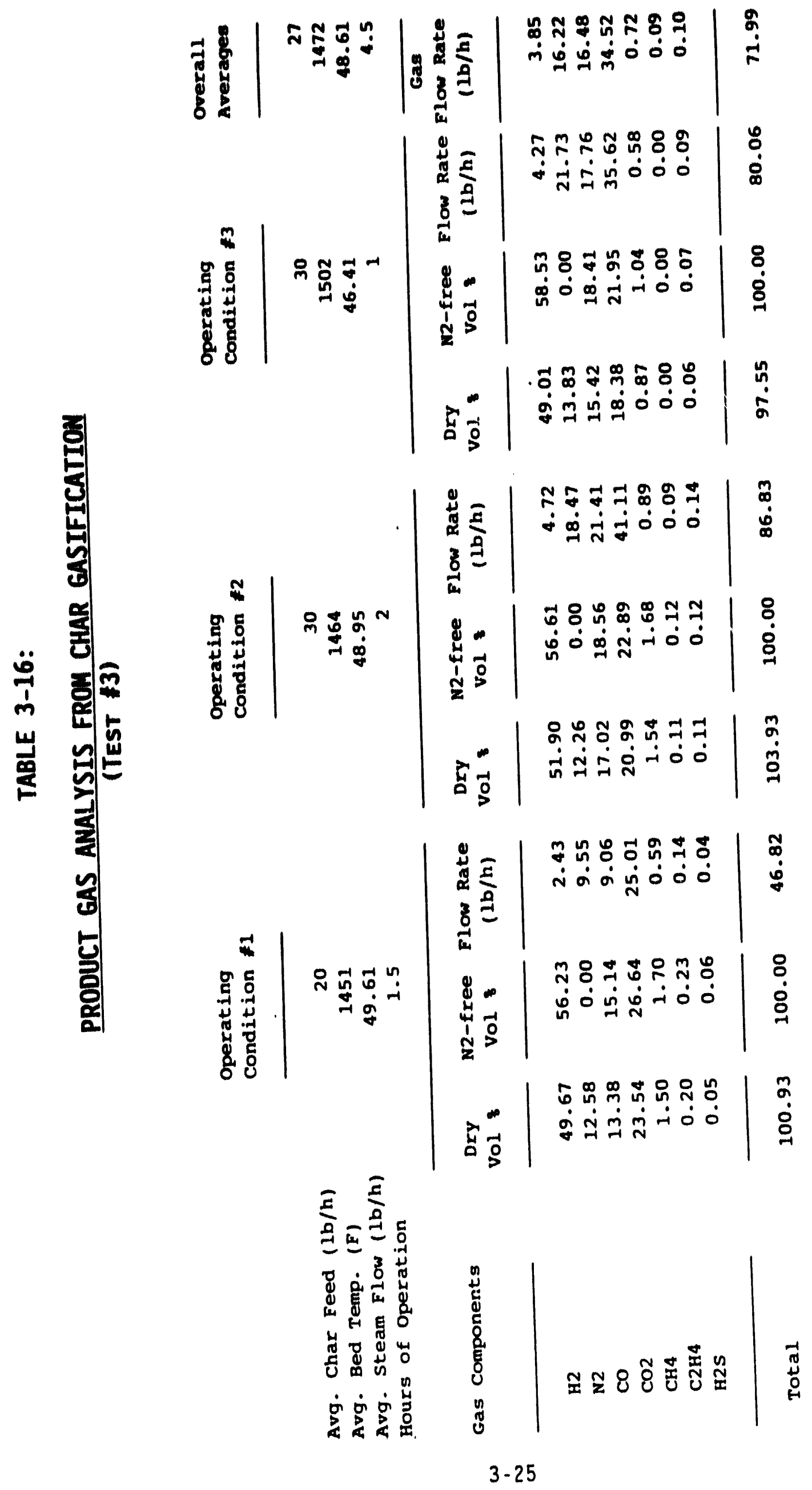


TABLE 3-17:

CHAR GASIFICATTON TEST SUMMARY

(TEST \#2)

\section{INPUT (lbs)}

char:

Initial Bed

Total Feed

Limestone:

Initial Bed

Steam Flow

Nitrogen Purge

TOTAL
55

200

240

428

78

1001
OUTPUT (llbs)

Soltds:

Final Bed

Cyclone Catch

Filter Catch

0
229

60

Product Gas:

Generated

Nitrogen

514

Water Vapor

36

TOTAL

917

LOSS (unaccounted)

TABLE 3-18:

CHAR GASIFICATION TEST SUMMARY

(TEST \#3)

\section{INPUI (lbs)}

Char:

Initial Bed

Total Feed

Sand:

Initial Bed

Steam Flow

Nitrogen Purge

TOTAL
0

143

373

219

44

779
QUTPUI (lbs)

Solids:

Final Bed

260

Cyclone Catch

116

Filter Catch

Product Gas:

Generated

Nitrogen

Water Vapor

168

TOTAL

655

LOSS (unaccounted) 


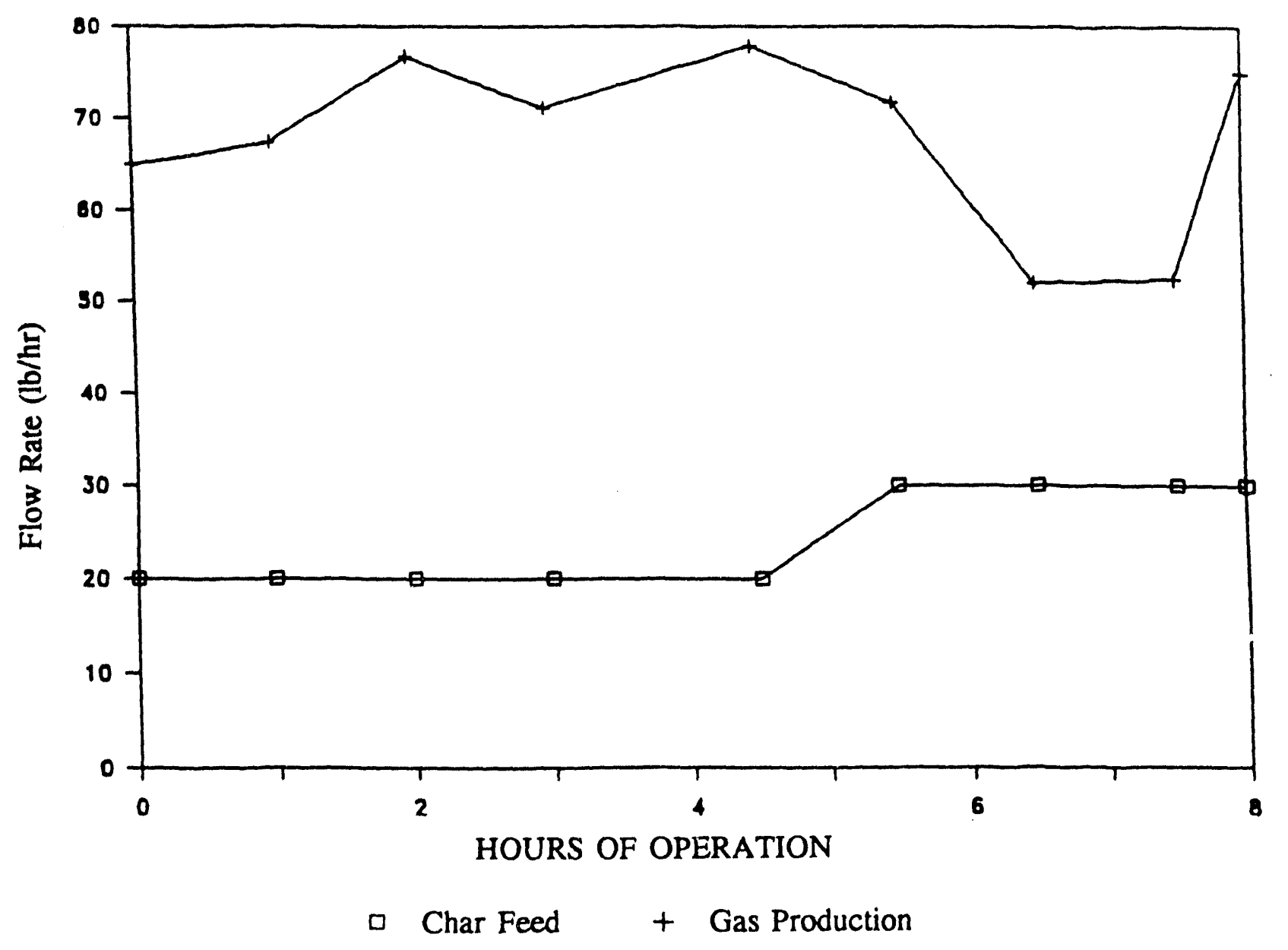

FIGURE 3-5: CHAR FEED AND GAS PRODUCTION VS. TIME (TEST \#2) 


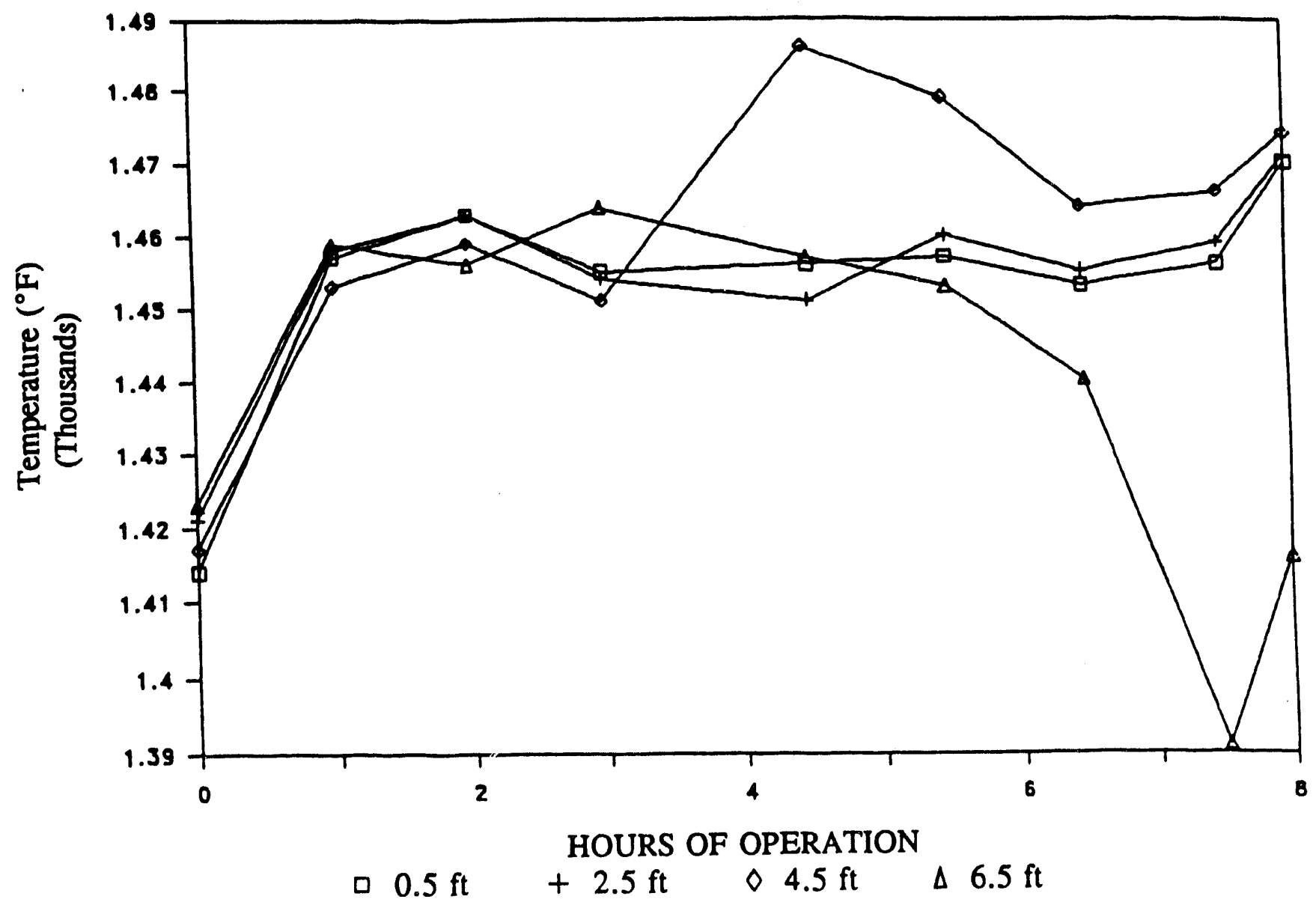

FIGURE 3-6: BED TEMPERATURE VS. TIME

(TEST \#2) 


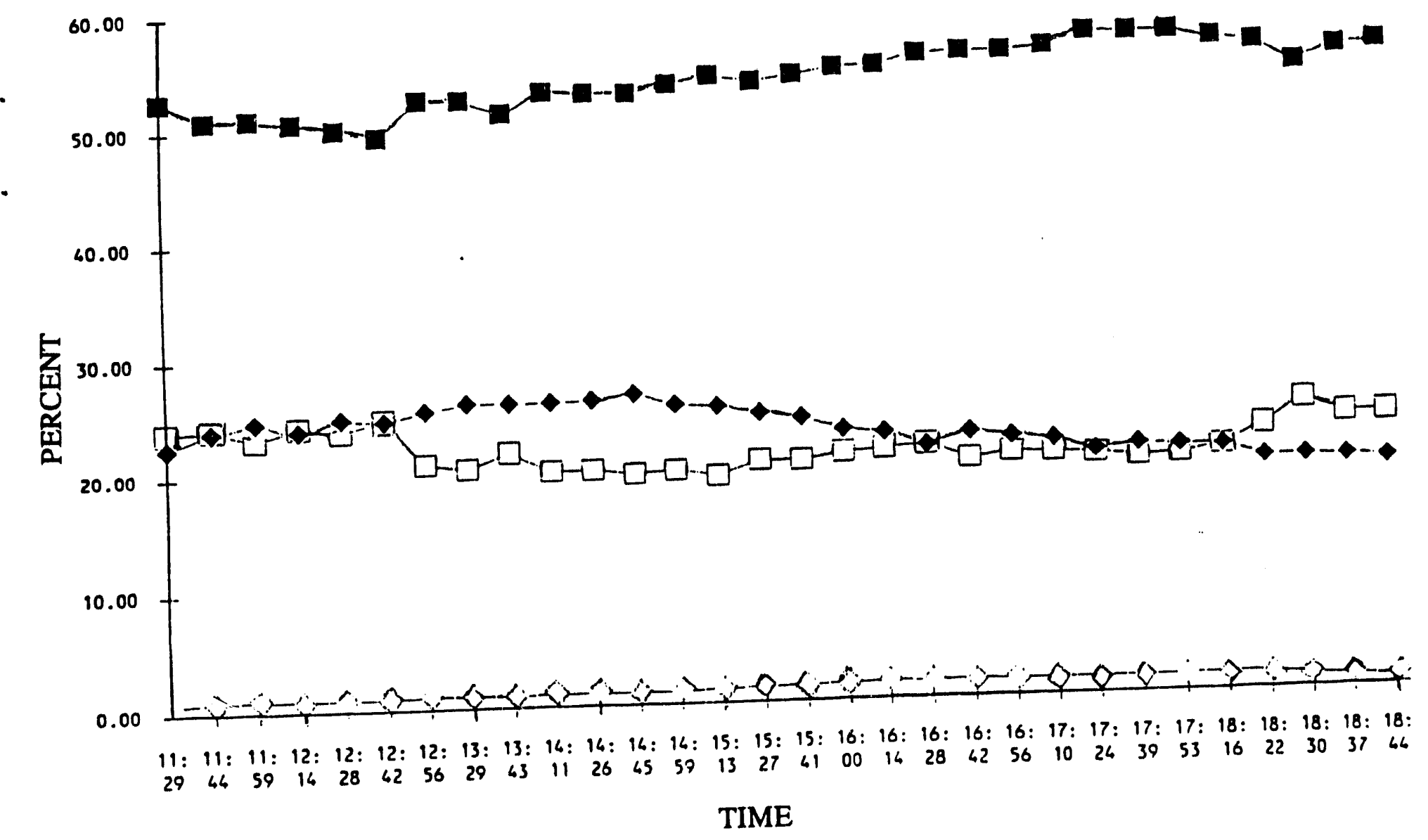

FIGURE 3-7: PRODUCT GAS (TEST \#2) 


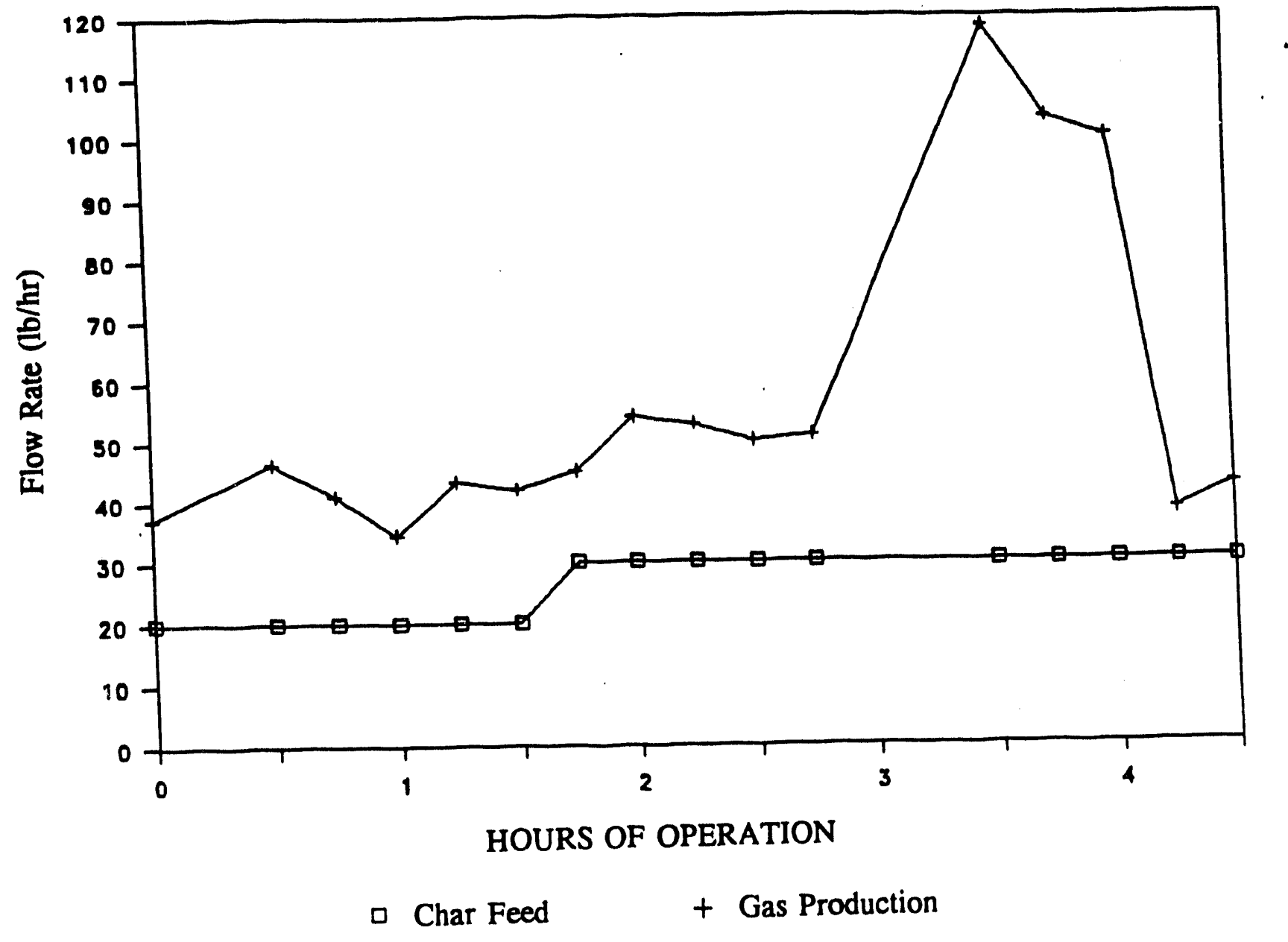
FIGURE 3-8: CHAR FEED AND GAS PRODUCTION vS. TIME
(TEST \#3) 


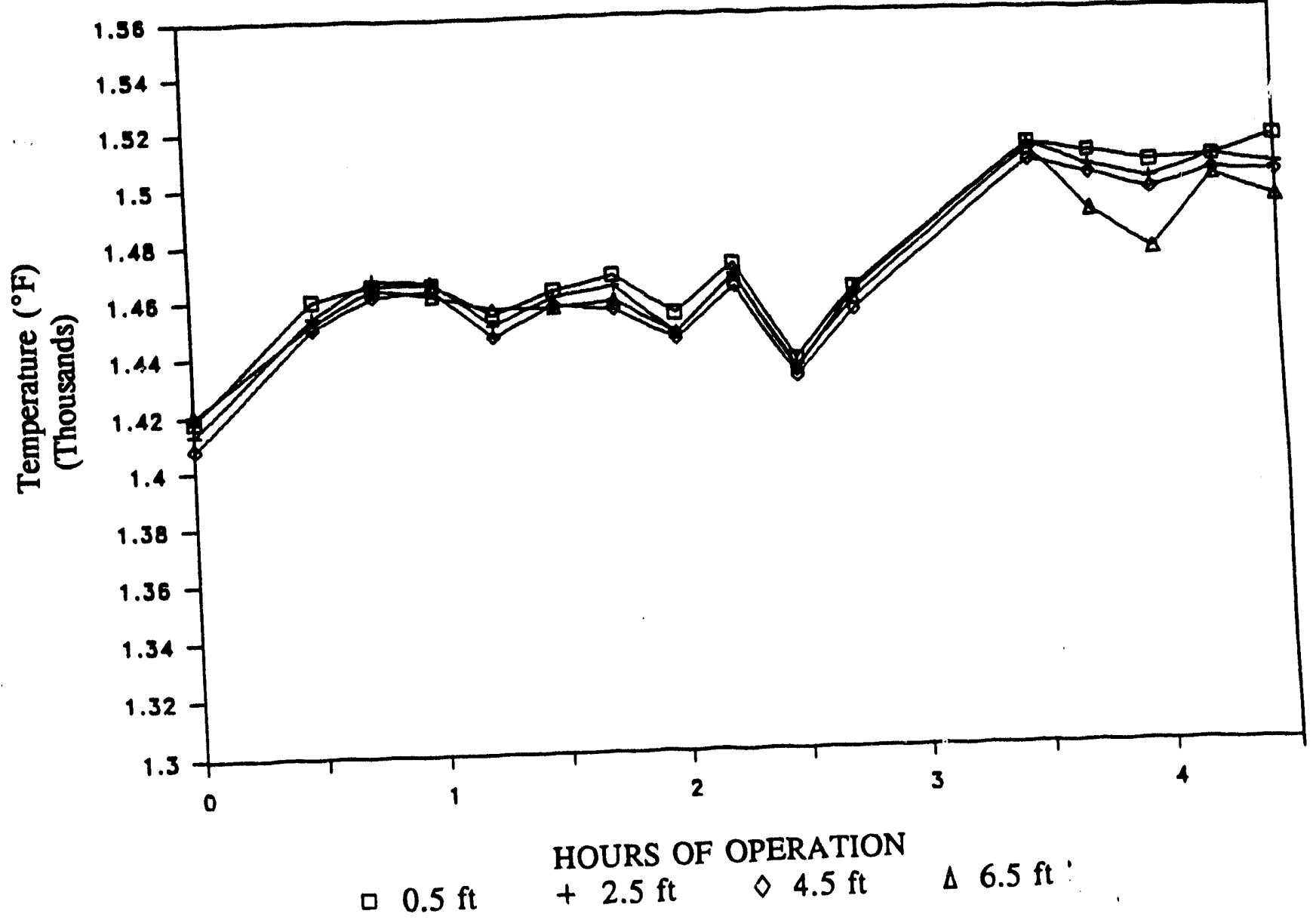

FIGURE 3-9: REACTOR BED TEMPERATURE VS. TIME (TEST \#3) 


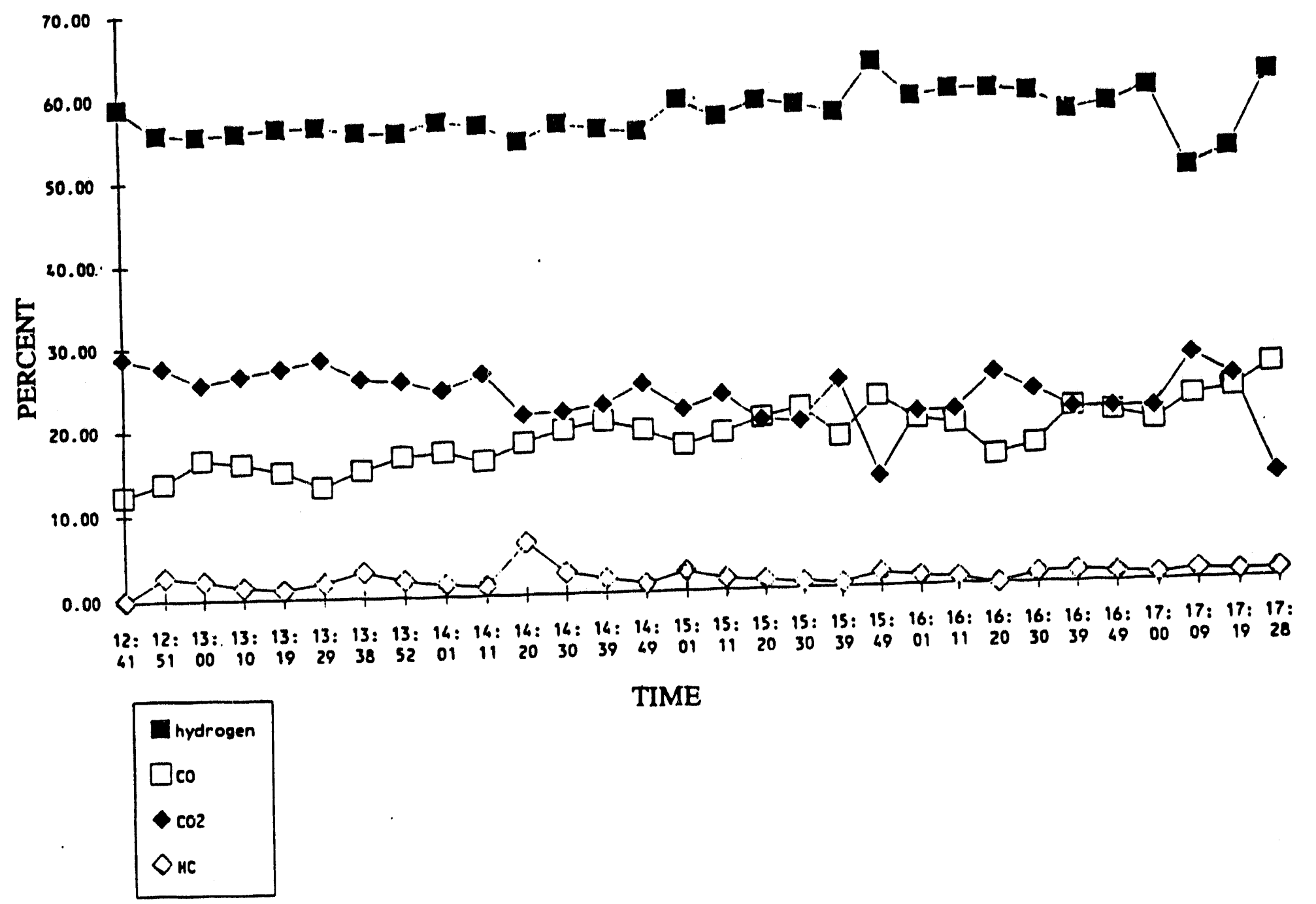

FIGURE 3-10: PRODUCT GAS (TEST \#3) 


\subsection{MILD CHAR GASIFICATION DATA ANALYSIS}

The chemical analyses received from Core Laboratories are summarized in Iables 3-19 and 3-20. Detailed material balances for the two successful test runs (Tests 2 and 3) were done and are tabulated in Iables 3-21 and 3-22.

For Test $\# 2$ (Table 3-21), corrections were made for the $\mathrm{CO}_{2}$ produced by calcination of the 1 imestone bed. An average rate of calcination over the time period of first operating condition was assumed. Results show a carbon-to-gas conversion of 80 percent for most runs. However, the results are not conclusive as to which bed material yields better carbon conversion, and requires that we make a few more tests.

Comparisons were made with the results reported by Sears et. al ${ }^{(5)}$ of the University of North Dakota. It can be seen from Iable 3-23 that the percentages of solid carbon converted to gaseous carbon are reasonably similar. It should be noted that Sears et. al. used Wyodak coal with direct oxygen heating whereas MTCI used char and indirect heating. Although the coal is much more volatile than the char, the MTCI gasifier achieved higher carbon conversion rates for similar temperatures regardless of bed material.

TABLE 3-23:

COMPARISON OF MTCI RESULTS WITH

IHAT OF UNIVERSITY OF NORTH DAKOTA

\begin{tabular}{|c|c|c|c|c|c|}
\hline \multirow{3}{*}{$\begin{array}{l}\text { FEED } \\
\text { BED MATERIAL }\end{array}$} & \multicolumn{3}{|c|}{ UNIV. OF NORTH DAKOTA } & \multicolumn{2}{|c|}{ MTCI } \\
\hline & \multicolumn{3}{|c|}{ WYODAK COAL } & \multicolumn{2}{|c|}{ CHAR } \\
\hline & & LIMESTON & & LIMESTONE & SAND \\
\hline BED TEMPERATURE $\left({ }^{\circ} \mathrm{F}\right)$ & 1384 & 1474 & 1483 & 1456 & 1472 \\
\hline STEAM:C RATIO & 2.43 & 3.17 & 1.16 & 2.74 & 2.29 \\
\hline $\mathrm{O}_{2}:$ C RATIO & 0.45 & 0.42 & 0.30 & - & - \\
\hline C IN $(1 \mathrm{~b} / \mathrm{hr})$ & 9.94 & 7.72 & 14.25 & 20.35 & 21.76 \\
\hline C OUT AS PRODUCT GAS (lb/hr) & 7.01 & 6.26 & 10.24 & 17.73 & 17.47 \\
\hline PERCENTAGE CONVERSION TO GAS & 70.52 & 81.09 & 71.86 & 87.13 & 80.28 \\
\hline
\end{tabular}


TABLE 3-19:

\section{Chemtcal Analysts of Chas}

\begin{tabular}{lcr} 
PROXIMATE ANALYSIS (Wt.\%) & & \\
& AS REC'D & DRY \\
\cline { 2 - 3 } Moisture & 1.28 & \\
Volatile & 11.02 & 11.16 \\
Fixed Carbon & 77.27 & 78.27 \\
Ash & 10.44 & 10.58 \\
ULTIMATE ANALYSIS (Wt.\%) & & \\
Carbon & & \\
Hydrogen & & 82.66 \\
Nitrogen & 1.98 \\
Oxygen & & 1.08 \\
Sulfur & & 3.33 \\
Ash & & 0.37 \\
\end{tabular}

TABLE 3-20:

TOtal ORGanic Carbon In the Gasification Products

\begin{tabular}{|c|c|c|c|c|c|}
\hline \multirow[b]{2}{*}{ OPERATING CONDITIONS } & \multicolumn{2}{|c|}{ IEST \#2 } & \multicolumn{3}{|c|}{ IEST \#3 } \\
\hline & $\# 1$ & $\# 2$ & $\dddot{m i}$ & \#2 & $\# 3$ \\
\hline BED REMAINDER & 0.51 & 0.44 & 0.01 & 0.05 & 0.09 \\
\hline CYCLONE FINES & 20.42 & 14.63 & 2.65 & 6.37 & 4.29 \\
\hline \multicolumn{6}{|l|}{ VENTURI SCRUBBER FINES } \\
\hline ORGANIC C (Wt.\%) & & 27.14 & & & \\
\hline V.S. FINES MOISTURE (Wt.\%) & & 67.06 & & & \\
\hline
\end{tabular}


TABLE 3-21:

MATERTAL BALANCE FOR CHAR GASIFICATION TESI \#2

TEST DATE:

BED MATERIAL:

OPERATING CONDITION:

REACTOR BED TEMPERATURE ('F)

STEAM:C RATIO

DURATION OF OPERATION (hrs)

MASS BALANCE

INPUT $(1 \mathrm{~b} / \mathrm{hr})$

CHAR

STEAM

NITROGEN

TOTAL

OUTPUT (Ib/hr)

CYCLONE FINES

VENTURI SCRUBBER FINES

PRODUCT GAS

NITROGEN

WATER

TOTAL

MASS CLOSURE (\%)
\#1

1450

3.29

4.50

21.00

56.31

9.70

87.01

6.28

2.50

49.35

9.70

18.02

85.85

98.67

ELEMENTAL BALANCE (Dry, Exc1. $N_{2}$-purge) INPUT $(1 \mathrm{~b} / \mathrm{hr})$

CARBON

HYDROGEN

NITROGEN

OXYGEN

SULFUR

ASH

OUTPUT $(1 \mathrm{~b} / \mathrm{hr})$

CARBON

HYDROGEN

NITROGEN

OXYGEN

SULFUR
17.14

6.67

0.22

50.75

0.08

2.19

18.46

6.36

44.46

0.05
AUGUST 15, 1990

LIMESTONE

\section{\#2 AVERAGE}

\section{2}

2.03

3.50

1456

2.74

4.00

24.94

30.00

49.79

53.46

9.91

9.79

89.70

88.19

6.60

6.42

2.50

2.50

57.57

52.95

9.91

9.79

12.43

15.57

89.01

87.23

99.23

98.92

24.48

20.35

6.12

0.32

45.25

0.11

3.13

6.43

0.27

48.34

0.09

2.60

21.26

5.62

19.69

6.04

45.97

0.06

45.12

0.05

"Adjusted for $\mathrm{CO}_{2}$ produced from calcination of 1 imestone. 
MATERTAL BALANCE EOR CHAR GASIETCATION TEST 12 (CONT'D)

TEST DATE:

BED MATERIAL:

OPERATING CONDITION:

PRODUCT GAS ANALYSIS

VOLUMETRIC $*$ (Dry)
$\mathrm{CH}_{4}$

$\mathrm{C}_{2} \mathrm{H}_{4}$

$\mathrm{H}_{2} \mathrm{~S}$

TOTAL

AVG. MOL. WT.

FLOW RATE ( $\begin{aligned} & \text { lb/hr) } \\ & \text { scfh) }\end{aligned}$

HYDROGEN PRODUCTION RATE $\left(\begin{array}{l}(\mathrm{lb} / \mathrm{hr} \text { ) } \\ (\mathrm{scfh})\end{array}\right.$

$H_{2}(1 \mathrm{~b} / \mathrm{hr}) /$ MAF CHAR $(1 \mathrm{~b} / \mathrm{hr})$

$\mathrm{H}_{2}$ (scfh) / MAF CHAR (1b/hr)

CO (lb/hr) / MAF CHAR (1b/hr)

$\mathrm{CO}_{2}(1 \mathrm{~b} / \mathrm{hr})$ / MAF CHAR $(\mathrm{lb} / \mathrm{hr})$

TH. $\mathrm{H}_{2}(1 \mathrm{~b} / \mathrm{hr})$ / MAF CHAR $(1 \mathrm{~b} / \mathrm{hr})$

TH. $\mathrm{H}_{2}$ (scfh) / MAF CHAR ( $\mathrm{lb} / \mathrm{hr}$ )

(Theoretical $\mathrm{H}_{2}=\mathrm{H}_{2}+\mathrm{CO}$ )

C IN GASES $(1 \mathrm{~b} / \mathrm{hr})^{*}$

C IN CHAR (1b/hr)

PERCENT CARBON CONVERSION
51.86

22.33

24.80

0.97

11

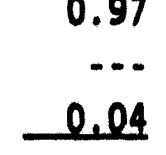

100.00

18.38

73.79

1521.29

4.20

788.64

42.54

1.35

1.05

0.32

60.64

16.50

17.14

96.28
0.23
AUGUST 15, 1990 LIMESTONE

12 aVERAGE

"Adjusted for $\mathrm{CO}_{2}$ produced from calcination of 1 imestone.

55.19

20.86

22.22

1.67

0.05

100.00

17.01

61.07

1360.69

3.98

747.04

0.15

28.21

0.79

1.19

0.21

38.82

19.30

24.48

78.85
53.32

21.69

23.67

1.28

0.04

100.00

17.78

68.23

1451.03

4.11

770.44

0.19

36.27

1.11

1.11

0.27

51.09

17.73

20.35

88.65 
TABLE 3-22:

MATERTAL BALANCE FOR CHAR GASIFICATTON IESI 3

TEST DATE:

BED MATERIAL:

OPERATING CONDITION:

REACTOR BED TEMPERATURE ( ${ }^{\circ} F$ )

STEAM:C RATIO

DURATION OF OPERATION (hrs)

MASS BALANCE

INPUT $(1 \mathrm{~b} / \mathrm{hr})$

CHAR

STEAM

NITROGEN

TOTAL

OUTPUT (16/hr)

CYCLONE FINES

VENTURI SCRUBBER FINES

PRODUCT GAS

NITROGEN

WATER

TOTAL

MASS CLOSURE (\%)
AUGUST 16, 1990

SAND

$\begin{array}{rrrr}\| & \boldsymbol{H} & \boldsymbol{H} & \text { AVG. } \\ 1451 & 1462 & 1502 & 1472 \\ 3.00 & 1.97 & 1.87 & 2.29 \\ 1.50 & 2.00 & 1.00 & 4.50\end{array}$

20.00

49.61

30.00

48.95

15.47

30.00

26.67

9.55

24.42

46.41

48.61

79.16

3.28

4.00

42.21

9.55

27.12

78.88

99.64

3.07

4.00

65.13

15.47

12.79

19.23

14.33

95,65

89.61

93.39

4.87

4.00

63.40

19.23

12.80

3.54

4.00

57.11

14.33

17.57

$25.44 \quad 89.01$

98.91

95.78

99.33

ELEMENTAL BALANCE (Dry, Excl. N2-purge) INPUT $(1 \mathrm{~b} / \mathrm{hr})$

CARBON

16.32

5.90

24.48

6.03

0.21

NITROGEN

44.76

OXYGEN

SULFUR

0.07

ASH

2.09

0.32

44.50

0.11

3.13

24.48

5.74

21.76

0.32

5.92

42.24

0.11

44.08

44.08

3.13

2.78

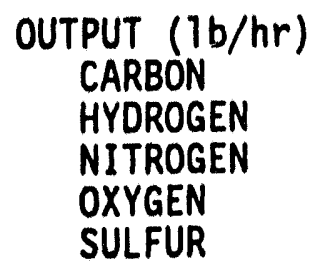

14.97

5.89

22.19

6.64

22.14

4.55

19.77

40.26

37.24

0.12

36.50
0.07

38.08 


\section{MATERTAL BALANCE FOR CHAR GASIFICATION TEST 3} (CONT'D)

\section{TEST DATE: \\ BED MATERIAL:}

OPERATING CONDITION:

PRODUCT GAS ANALYSIS

VOLUMETRIC \% (Dry)

$\mathrm{H}_{2}$
$\mathrm{CO}$
$\mathrm{CO}_{2}$
$\mathrm{CH}_{4}$
$\mathrm{C}_{2} \mathrm{H}_{4}$
$\mathrm{H}_{2} \mathrm{~S}$
TOTAL
GO MOL. WT.
OW RATE (ib/hr)
scfh)

HYDROGEN PRODUCTION RATE $\left(\begin{array}{l}1 \mathrm{~b} / \mathrm{hr} \text { ) } \\ \text { scfh) }\end{array}\right.$

$\mathrm{H}_{2}$ (1b/hr) / MAF CHAR (1b/hr)

$\mathrm{H}_{2}$ (scfh) / MAF CHAR (Ib,'hr)

CO (1b/hr) / MAF CHAR (1b/hr)

$\mathrm{CO}_{2}(1 \mathrm{~b} / \mathrm{hr})$ / MAF CHAR $(1 \mathrm{~b} / \mathrm{hr})$

TH. $\mathrm{H}_{2}(1 \mathrm{~b} / \mathrm{hr})$ / MAF CHAR $(1 \mathrm{~b} / \mathrm{hr})$

TH. $\mathrm{H}_{2}$ (scfh) / MAF CHAR (1b/hr)

(Theoretical $\mathrm{H}_{2}=\mathrm{H}_{2}+\mathrm{CO}$ )

C IN GASES $(\mathrm{Ib} / \mathrm{hr})$

C IN CHAR ( Ib/hr)

PERCENT CARBON CONVERSION

\section{AUGUST 16,1990}

$11 \quad 13 \quad$ AVG.

\begin{tabular}{rrrr}
56.23 & 56.65 & 58.55 & 56.93 \\
15.12 & 18.57 & 18.34 & 17.37 \\
26.66 & 22.89 & 22.01 & 23.95 \\
1.71 & 1.66 & 1.04 & 1.54 \\
0.23 & 0.12 & 0.00 & 0.13 \\
0.06 & 0.12 & 0.07 & 0.09 \\
\hline 100.00 & 100.00 & 100.00 & 100.00 \\
17.46 & 16.76 & 16.19 & 16.84 \\
42.21 & 65.13 & 63.40 & 57.11 \\
916.27 & 1472.45 & 1484.23 & 1285.42
\end{tabular}

$\begin{array}{llll}2.68 & 4.98 & 2.97 & 3.76\end{array}$

$\begin{array}{llll}502.74 & 933.85 & 556.48 & 706.29\end{array}$

$\begin{array}{rrrr}0.15 & 0.28 & 0.11 & 0.16 \\ 28.47 & 52.89 & 21.01 & 30.00 \\ 0.58 & 0.77 & 0.73 & 0.71 \\ 1.60 & 1.48 & 0.94 & 1.51\end{array}$

$\begin{array}{rrrr}0.19 & 0.34 & 0.16 & 0.21 \\ 36.25 & 63.20 & 30.82 & 39.55\end{array}$

12.69

20.12

19.32

17.47

16.32

24.48

24.48

21.76

77.77

78.93

80.27 


\subsection{LONG DURATION MILD CHAR GASIFICATION CHAR TESTS}

A major problem encountered during the earlier char gasification tests was achieving the required bed temperature of $1550^{\circ} \mathrm{F}$. Since the pulse combustor was only designed for a maximum firing rate of $750 \mathrm{KBtu} / \mathrm{hr}$, an increase in firing rate would only achleve incomplete combustion and high tube temperatures. The surface area to volume ratio of the two tube gasifier is high and the stainless steel reactor is insuffictently insulated from the outside resulting in excessive heat losses from the reactor. A modification to the reactor to reduce the heat losses would be very benefictal and easily accomplished. The existing 18-inch reactor shell was therefore modified by adding a refractory lining to its inside wall.

A long duration test was conducted using mild gasification char as the feedstock and steam as the fluidizing media. Limestone bed was first calcined to 1 ime at $1400^{\circ} \mathrm{F}$ and then it was used as the bed material. Two tests using char feedstock were conducted consecutively: one at $1440^{\circ} \mathrm{F}$ and the second one at an average bed temperature of $1507^{\circ} \mathrm{F}$. The long duration char tests accumulated a total of 45 hours at two conditions. The gasification proceeded at an average temperature of $1440^{\circ} \mathrm{F}$ for the first 15 hours and at an average temperature of $1507^{\circ} \mathrm{F}$ for the remainder of the period.

The feed char (about 400 lbs) was obtained from AMAX Research and Development Company of Golden, Colorado. This char was originally generated by Western Research Institute under METC Contract DE-AC21-87MC24268 in an inclined fluid bed by mild gasification of a Wyodak coal. AMAX further gasified this char under hydrogen pressure (between 200 to $400 \mathrm{ps} 1$ ) and at temperatures ranging from $1400^{\circ}$ to $1450^{\circ} \mathrm{F}$, converting about 25 to $35 \%$ of the carbon to methane. The residual char from AMAX's hydro-gasifier was shipped to MTCI. It had about 5 to $7.5 \%$ VM and $13 \%$ ash. Ultimate analys is of the char is given in Iable 3-24 and compared with other feeds tested in this gasifier. 
ULTTMATE AMALYSTS OF VARTOUS FEePSTOCKS TESTED

\begin{tabular}{|c|c|c|c|c|c|}
\hline & MTCI CHAR & LIGNITE & $\begin{array}{c}\text { ASH } \\
\text { CONCENTRATE }\end{array}$ & $\begin{array}{l}\text { COAL } \\
\text { (BLACK } \\
\text { IHUNDER) }\end{array}$ & $\begin{array}{l}\text { AMAX } \\
\text { CHAR }\end{array}$ \\
\hline $\begin{array}{l}\text { MOISTURE } \\
\text { ASH } \\
\text { CARBON } \\
\text { HYDROGEN } \\
\text { OXYGEN } \\
\text { SULFUR } \\
\text { NITROGEN }\end{array}$ & $\begin{array}{r}0.65 \\
14.95 \\
76.64 \\
1.57 \\
4.72 \\
0.40 \\
1.07 \\
\end{array}$ & $\begin{array}{r}33.71 \\
5.94 \\
44.28 \\
3.21 \\
11.60 \\
0.69 \\
0.57 \\
\end{array}$ & $\begin{array}{r}0.36 \\
39.02 \\
52.99 \\
3.10 \\
0.00 \\
3.81 \\
0.72 \\
\end{array}$ & $\begin{array}{r}19.30 \\
5.16 \\
55.55 \\
3.67 \\
15.11 \\
0.39 \\
0.82 \\
\end{array}$ & $\begin{array}{r}1.55 \\
12.85 \\
81.02 \\
2.08 \\
1.03 \\
0.52 \\
0.95 \\
\end{array}$ \\
\hline TOTAL & 100.00 & 100.00 & 100.00 & 100.00 & 100.00 \\
\hline $\begin{array}{l}\text { HHV (Btu/Ib MAF) } \\
\text { VOLATILE (\%) }\end{array}$ & $\begin{array}{l}13955 \\
12.30\end{array}$ & $\begin{array}{l}12197 \\
28.77\end{array}$ & $\begin{array}{l}16460 \\
23.08\end{array}$ & $\begin{array}{l}12145 \\
35.93\end{array}$ & $\begin{array}{c}4.5 \text { to } \\
6.0\end{array}$ \\
\hline
\end{tabular}

Iable 3-25 gives the operating conditions and the product gas analysis. Iable 3-26 gives the mass balance comparison of a previous short duration test (1) and the current long duration test (2). In the short duration test $\mathrm{CO}_{2}$ released by calcination of the 1 imestone during char gasification resulted in higher rates of $\mathrm{CO}_{2}$ in the product gas. In the long duration test with precalcined lime, the uncertainty of $\mathrm{CO}_{2}$ formed release was el iminated during the test and the overall char gasification mass balance was 99 percent.

Iable 3-27 gives the elemental balance for the long duration test. The carbon, hydrogen and oxygen balances were quite good - $99.5 \%, 91.6 \%$ and $97.1 \%$, respectively. The carbon conversion to gas was $91.5 \%$ at $1507^{\circ} \mathrm{F}$ and $80.4 \%$ at $1440^{\circ} \mathrm{F}$.

Iable 3-28 gives the elemental balance for hydrogen and oxygen in the water and gas phases. The water used for the reaction is approximately $528.3 \mathrm{lbs}$. Iable 3-29 represents the water used in the reaction from the gas phase composition and the carbon steam/water gas shift reaction. The water used was approximately 538 pounds. The steam used in the reactor calculated by difference is 547 pounds. The differences between the three methods was less than 6 percent, indicating a fairly accurate mass balance. 
TABLE 3-25:

OPERATING CONDITIONS AND PRODUCT GAS ANALYSIS

\begin{tabular}{|c|c|c|c|c|}
\hline IEST NUMBER & $8-16-90$ & $8-15-90$ & $\begin{array}{r}6-2-92 \\
6-3-92 \\
\end{array}$ & $\begin{array}{r}6-3-92 \\
6-4-92 \\
\end{array}$ \\
\hline $\begin{array}{l}\text { AVG. CHAR FEED }(1 \mathrm{~b} / \mathrm{hr}) \\
\text { AVG. BED TEMP. }(\circ \mathrm{F}) \\
\text { AVG. STEAM FLOW }(1 \mathrm{~b} / \mathrm{hr}) \\
\text { HOURS OF OPERATION } \\
\text { BED MEDIA } \\
\text { NO. OF PULSE TUBES }\end{array}$ & $\begin{array}{r}20 \\
1450 \\
49.60 \\
5 \\
\text { SAND } \\
8\end{array}$ & $\begin{array}{r}25 \\
1456 \\
56.30 \\
8 \\
\text { LIMESTONE } \\
8\end{array}$ & $\begin{array}{r}13.20 \\
1440 \\
20-25 \\
15 \\
\text { LIMESTONE } \\
2\end{array}$ & $\begin{array}{r}16.90 \\
1507 \\
20-25 \\
11 \\
\text { LIMESTONE } \\
2\end{array}$ \\
\hline $\begin{array}{l}\text { GAS COMPONENTS (\%V/V dry) } \\
\text { H2 } \\
\text { CO } \\
\text { CO2 } \\
\text { CH4+ } \\
\text { H2S } \\
\text { TOTAL }\end{array}$ & $\begin{array}{r}56.23 \\
15.14 \\
26.64 \\
1.93 \\
0.06 \\
100.00\end{array}$ & $\begin{array}{r}51.86 \\
22.34 \\
24.79 \\
0.97 \\
0.04 \\
100.00\end{array}$ & $\begin{array}{r}54.33 \\
27.81 \\
15.73 \\
2.10 \\
0.04 \\
100.00\end{array}$ & $\begin{array}{r}57.50 \\
20.28 \\
20.58 \\
1.57 \\
0.15 \\
100.00\end{array}$ \\
\hline $\begin{array}{l}\text { CARBON CONVERSION } \\
\text { TO GAS (Wt.\%) }\end{array}$ & 80.30 & 87.10 & 80.40 & 99.50 \\
\hline
\end{tabular}

TABLE 3-26:

MASS BALANCE FOR CHAR GASIFICATION TESTS

IEST

INPUT (1b):

LIMESTONE

Uncalcined

Calcined

CHAR FEED

STEAM

WATER IN V SCRUBBER

TOTAL

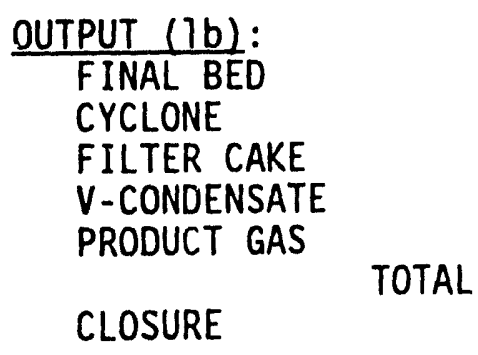

(1)

240

255

428

N.M.

923

0
229

60

N.M.

514

803

87
(2)

176

383

1115

800

2474

88
119
83
1368
794
2452
99




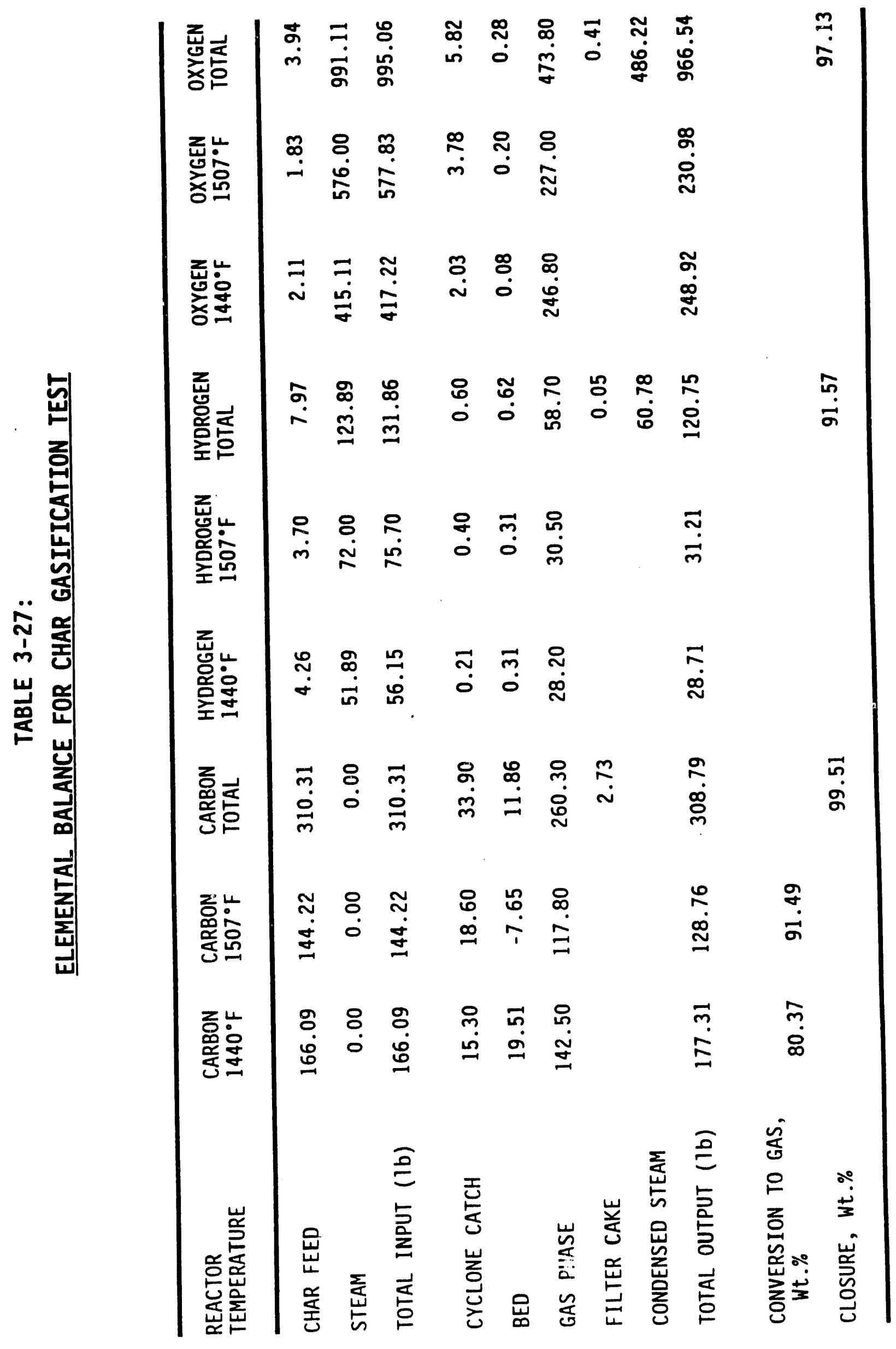


TABLE 3-28:

CHAR GASIFICATION - HYDROGEN + OXYGEN BALANCE

INPUT (1b):

COOLING WATER IN VENTURI SCRUBBER

STEAM TO REACTOR

800

1115

OUTPUT (1b):

VENTURI SCRUBBER LIQUID

1368

NET CONDENSATE IN VENTURI SCRUBBER

$1368-800=5681 b$

STEAM USED IN REACTION

$1115-568=547 \mathrm{lb}$

HYDROGEN IN GAS PHASE

$58.701 \mathrm{~b}$

OXYGEN IN $\mathrm{CO} / \mathrm{CO}_{2}$ GAS PHASE

$473.801 \mathrm{~b}$

(58.7 lb) $\mathrm{H}_{2}+(469.6 \mathrm{lb}) \mathrm{O}_{2}=$

(528.3 1b) $\mathrm{H}_{2} \mathrm{O}$

TABLE 3-29:

\section{CHAR GASIFICATION - 6/2/92 TO 6/4/92}

AVERAGE GAS COMPOSITION $\% \mathrm{~V} / \mathrm{V}$

$\begin{array}{lcl}\mathrm{H}_{2} & 55.91 & \frac{\mathrm{H}_{2}}{\mathrm{CO}_{2}}=3.1 \mathrm{~mole} / \mathrm{mole} \\ \mathrm{CH}_{4} & 1.84 & \frac{\mathrm{CO}}{\mathrm{CO}_{2}}=1.33 \mathrm{~mole} / \mathrm{mole} \\ \mathrm{CO} & 24.04 & \\ \mathrm{CO}_{2} & 18.11 & \\ \mathrm{H}_{2} \mathrm{~S} & 0.01 & \end{array}$

COMBINING CARBON-STEAM REACTION WITH WATER GAS SHIFT REACTION:

$(2.33) \mathrm{C}+(3.33) \mathrm{H}_{2} \mathrm{O} \rightarrow(1.33) \mathrm{CO}+(1) \mathrm{CO}_{2}+(3.33) \mathrm{H}_{2}$

CARBON IN GAS PHASE $=250.3 \mathrm{lbs}$

WATER USED IN REACTION $=\frac{260.3}{12} \times \frac{3.33}{2.33} \times 18=558 \mathrm{lbs}$ 
Eigure 3-11 shows the product gas composition over the entire test period. As shown in the figure, the gas composition was fairly constant and stable over the test period, indicating steady state operation. Figure 3-12 shows the temperature history for the char gasification in the test.

\subsection{SRC GASIFICATION TEST}

Two tests were conducted on December 17 th and 20th for the gasification of ash concentrate (SRC) from Southern Electric International, Southern Clean Fuels Division (SCFD). The ash concentrate was the residue of the coal liquefaction test run by SCFD. The feed material was crushed and screened to $<0.5$-inch size. A total of about 177 pounds of SRC was gasified in the two tests.

In the first run, sand was used as the fluidized bed material. The reactor was operated at an average temperature of $1381^{\circ} \mathrm{F}\left(749^{\circ} \mathrm{C}\right)$. A total of 101 pounds of feed material was loaded to the feeder and fed to the reactor at a rate of about $15 \mathrm{lb} / \mathrm{hr}$.

In the second run, limestone was used as the fluidized bed material. The reactor was operated at an average temperature of $1383^{\circ} \mathrm{F}\left(750^{\circ} \mathrm{C}\right)$. A total of 76 pounds of feed material was loaded to the feeder. The feed rate was set at about $15 \mathrm{lb} / \mathrm{hr}$. In this run, there was some difficulty in maintaining the bed temperature at $1380^{\circ} \mathrm{F}$. The combustor firing rate was therefore increased resulting in an increase in combustor temperature above $2600^{\circ} \mathrm{F}$. The high combustor temperature and defluidization at the bottom of the reactor led to the melting of one of the heat exchanger tubes. It was determined after the test that in order to avoid partial overheat of the reactor in the future, the fluidization gas should be introduced to the reactor at the position as close to the bottom as possible.

The results of the two tests are summarized in Table 3-30. The analysis of product gas for tests of December 17 and December 20 is 1isted in Table 3-31 and Table 3-32, respectively. The preliminary material balance is tabulated in Tables 3-33 and 3-34. Samples of feed material, bed material and cyclone catch 


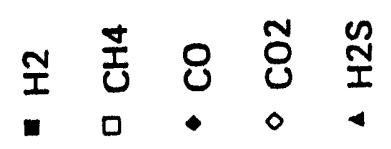
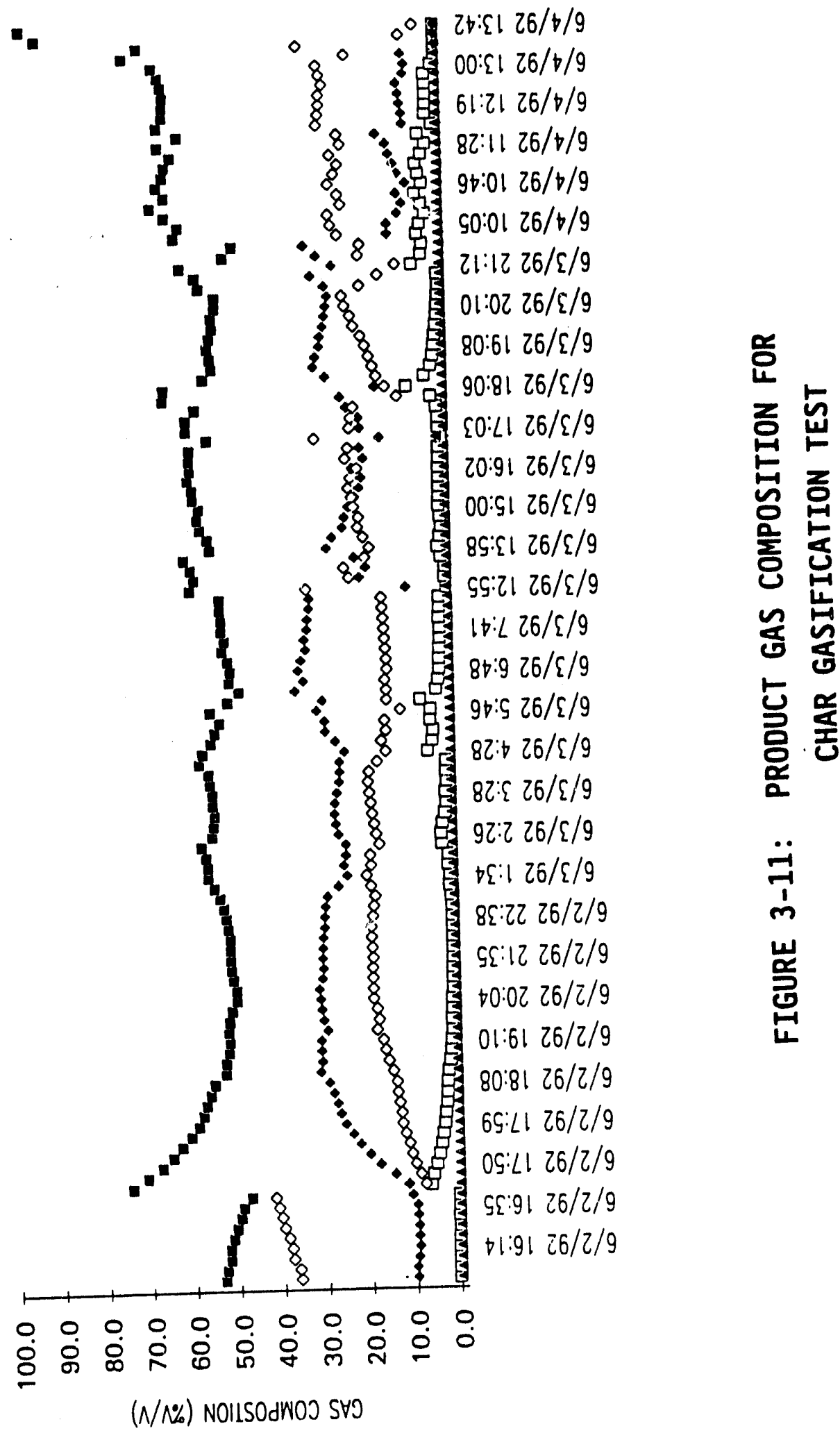


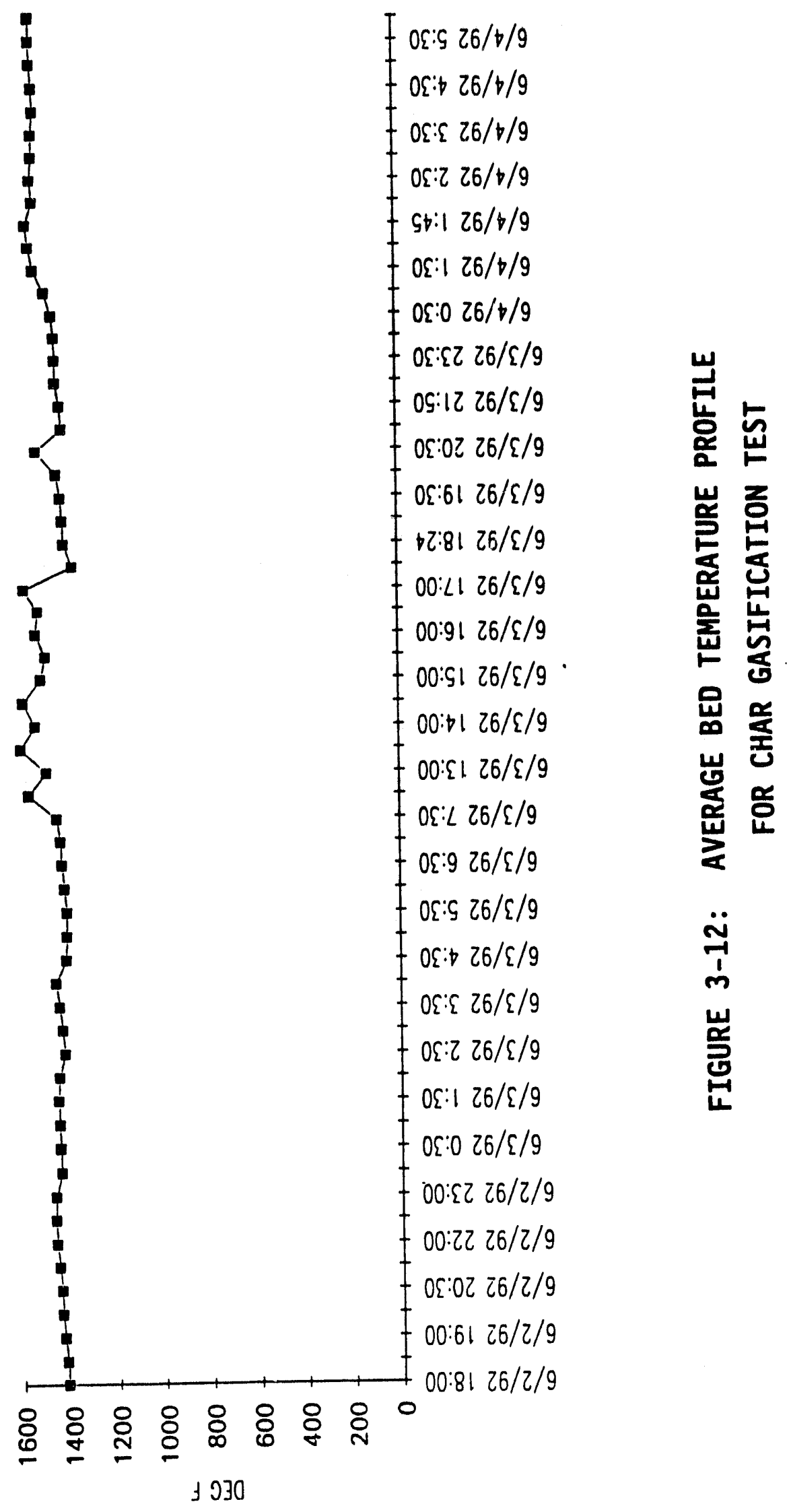


TABLE 3-30:

SRC GASIFICATION TEST CONDITIONS

\begin{tabular}{|c|c|c|}
\hline & DEC. 17,1990 & DEC. $20, \quad 1990$ \\
\hline HOURS OF OPERATION & 6 & 5.5 \\
\hline BED MATERIAL & Sand & Limestone \\
\hline AVERAGE BED TEMPERATURE $\left({ }^{\circ} F\right)$ & 1381 & 1383 \\
\hline AVERAGE FEED RATE $(\mathrm{lb} / \mathrm{hr})$ & 15 & 15 \\
\hline AVERAGE STEAM FLOW (lb/hr) & 33 & 26 \\
\hline GAS PROD. RATE $(\mathrm{lb} / \mathrm{hr})$ & 11.2 & 19.3 \\
\hline TOTAL GAS PROD. (1b) & 67 & 106 \\
\hline
\end{tabular}

TABLE 3-31:

PRODUCT GAS ANALYSIS OF SRC GASIFICATION (DEC. 17, 1990)

\begin{tabular}{crrr} 
COMPONENTS & DRY VOL.\% & $\mathrm{N}_{2}$-FREE VOL.\% & PROD. RATE (1bm/hr) \\
\cline { 1 - 2 } $\mathrm{O}_{2}$ & 2.51 & & \\
$\mathrm{~N}_{2}$ & 26.75 & & \\
$\mathrm{H}_{2}$ & 35.55 & 59.51 & 0.791 \\
$\mathrm{CO}_{2}$ & 17.35 & 29.58 & 8.649 \\
$\mathrm{CO}$ & 3.44 & 5.71 & 1.062 \\
$\mathrm{CH}_{4}$ & 2.16 & 3.70 & 0.394 \\
$\mathrm{C}_{2} \mathrm{H}_{4}$ & 0.23 & 0.41 & 0.077 \\
$\mathrm{C}_{2} \mathrm{H}_{6}$ & 0.14 & 0.24 & 0.048 \\
$\mathrm{C}_{3} \mathrm{H}_{6}$ & 0.06 & 0.10 & 0.029 \\
$\mathrm{C}_{3} \mathrm{H}_{3}$ & 0.03 & 0.06 & 0.017 \\
$\mathrm{C}_{4}-\mathrm{i}$ & 0.02 & 0.03 & 0.012 \\
$\mathrm{C}_{4}-\mathrm{n}$ & 0.04 & 0.07 & 0.025 \\
$\mathrm{H}_{2} \mathrm{~S}$ & 0.33 & 0.56 & 0.128 \\
TOTAL & 88.63 & 100.00 & 11.15 \\
\hline
\end{tabular}


TABLE 3-32:

PRODUCT GAS ANALYSIS OF SRC GASIFICATION (DEC. 20, 1990)

COMPONENTS

DRY VOL.\% $\mathrm{N}_{2}$-FREE VOL.\% PROD. RATE (lbm/hr)

$\mathbf{O}_{2}$

0.02

$\mathrm{N}_{2}$

15.67

$\mathrm{H}_{2}$

53.80

63.61

1.616

$\mathrm{CO}_{2}$

21.35

25.30

14.144

CO

5.85

6.91

2.459

$\mathrm{CH}_{4}$

2.81

3.33

0.676

$\mathrm{C}_{2} \mathrm{H}_{4}$

0.17

0.20

0.070

$\mathrm{CD}_{2} \mathrm{H}_{6}$

0.16

0.19

0.071

$\mathrm{C}_{3} \mathrm{H}_{6}$

0.04

0.05

0.026

$\mathrm{C}_{3} \mathrm{H}_{8}$

0.00

0.00

0.000

C4-i

0.01

0.03

0.020

C4-n

0.03

0.04

0.026

$\mathrm{H}_{2} \mathrm{~S}$

0.29

0.34

0.149

TOTAL

100.20

100.00

19.26 
TABLE 3-33:

PRELIMINARY MATERIAL BALANCE

(DEC. 17, 1990)

\begin{tabular}{lrlrr} 
INPUT (lbs) & & OUTPUT (Ibs) \\
Bed Original & 212 & & Bed Final & 271 \\
Total Feed & 102 & & Cyclone Catch & 6 \\
Steam Consumed & 44 & & Dry Product Gas & 67 \\
\hline Total & 358 & & Total & 344 \\
& & Loss & 14 \\
\hline
\end{tabular}

TABLE 3-34:

PRELIMINARY MATERIAL BALANCE

(DEC. 20, 1990)

INPUT (1bs)

Bed Original

Total Feed

Steam Consumed

Total

206

QUTPUT (1 bs)

76

Bed Final

179

Cycione Catch

80

Dry Product Gas

106

362

Loss 
were sent to an outside laboratory for analysis. Detailed material balance will be carried out after receiving the results of the chemical analysis.

The modifications to the reactor were completed and the fluidization gas is now introduced near the bottom of the reactor. It is anticipated that this should minimize any further local overheating.

The analytical results for the samples collected during the $12 / 17 / 90$ and $12 / 20 / 90$ tests were also received from Standard Laboratories. Proximate and Ultimate Analyses were performed for one ash concentrate feed sample, one bed sample each for 12/17/90 and 12/20/90 tests, and one cyclone char/ash sample each for the two tests. The analytical results are 1isted in Iable 3-35.

Based on the carbon concentrations given by the chemical analyses, the carbon balances for both SRC gasification tests were performed. The carbon balance for the 12/17/91 test is presented in Iable 3-36. Iable 3-37 shows the carbon balance for the $12 / 20 / 91$ test. For the 12/17/91 test, where silica sand was used as bed material, the analyzed total carbon of bed and cyclone sample was used directly as the organic carbon concentration. For the 12/20/91 test, where limestone was used as bed material, the total carbon in the bed and cyclone samples included organic carbon and carbonate carbon. The amount of carbon in the carbonate form was calculated by assuming that all the oxygen was related to carbonate. Although this assumption may not have been accurate in all cases, in this instance the amount of oxygen related to other elements was very small so that the assumption appeared to be the best approximation for the organic carbon calculation. Also listed in Tables 3-36 and 3-37 are carbon gasification efficiency $(\%)$, and carbon gasification rate. In calculating the total carbon out, the liquid product was omitted because the amount of liquid production in both tests was insignificant.

The caroon gasification efficiency is defined as

$$
\begin{aligned}
& \text { Carbon Gasification Recovery }(\%)= \frac{\text { Total Carbon }}{\text { Total Gas Carbon and }} \times 100 \\
& \text { Total Cyclone Carbon }
\end{aligned}
$$


焉员

군

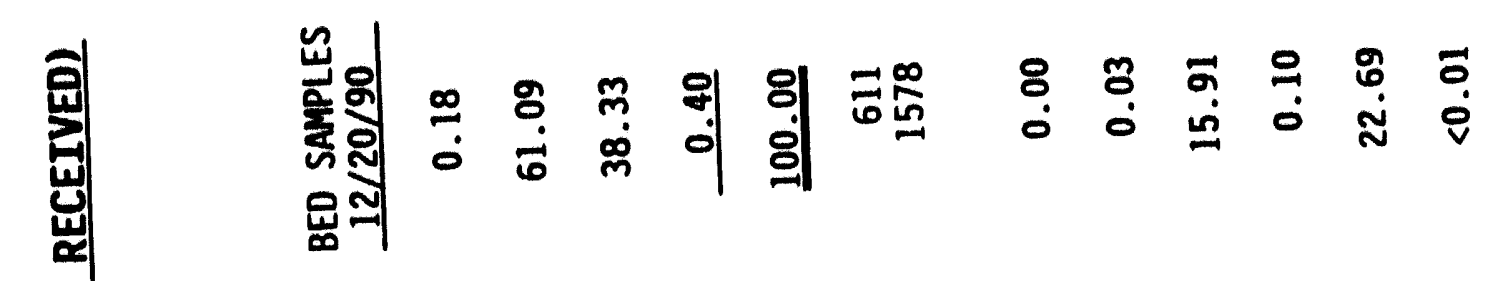

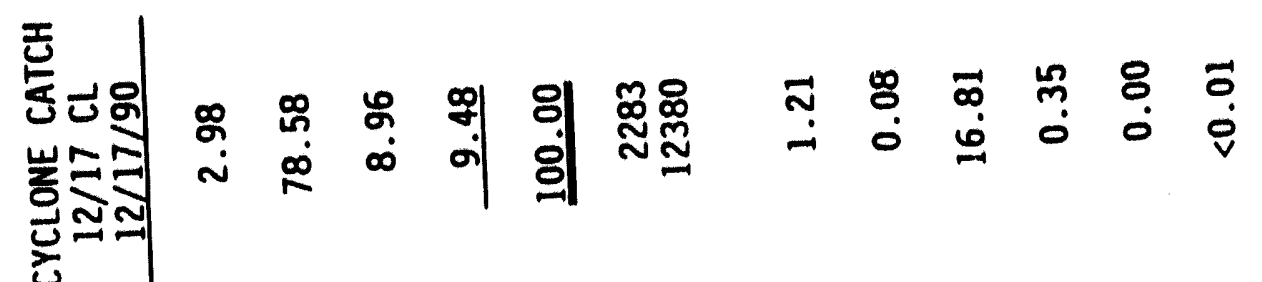

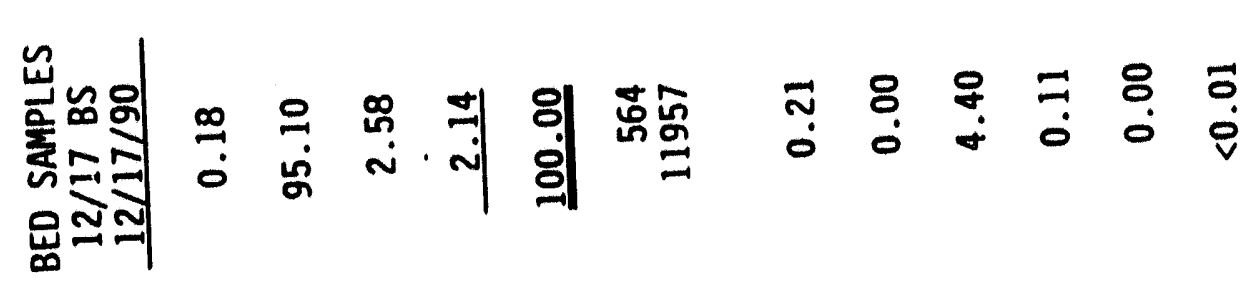

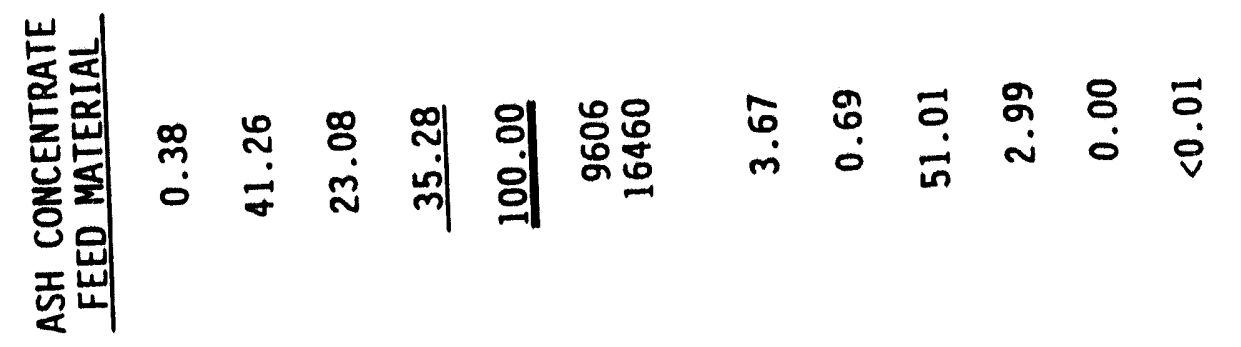
o 
TABLE 3-36:

\section{CARBON BALANCE FOR DECEMBER 17, 1990 GASIFICATION IEST}

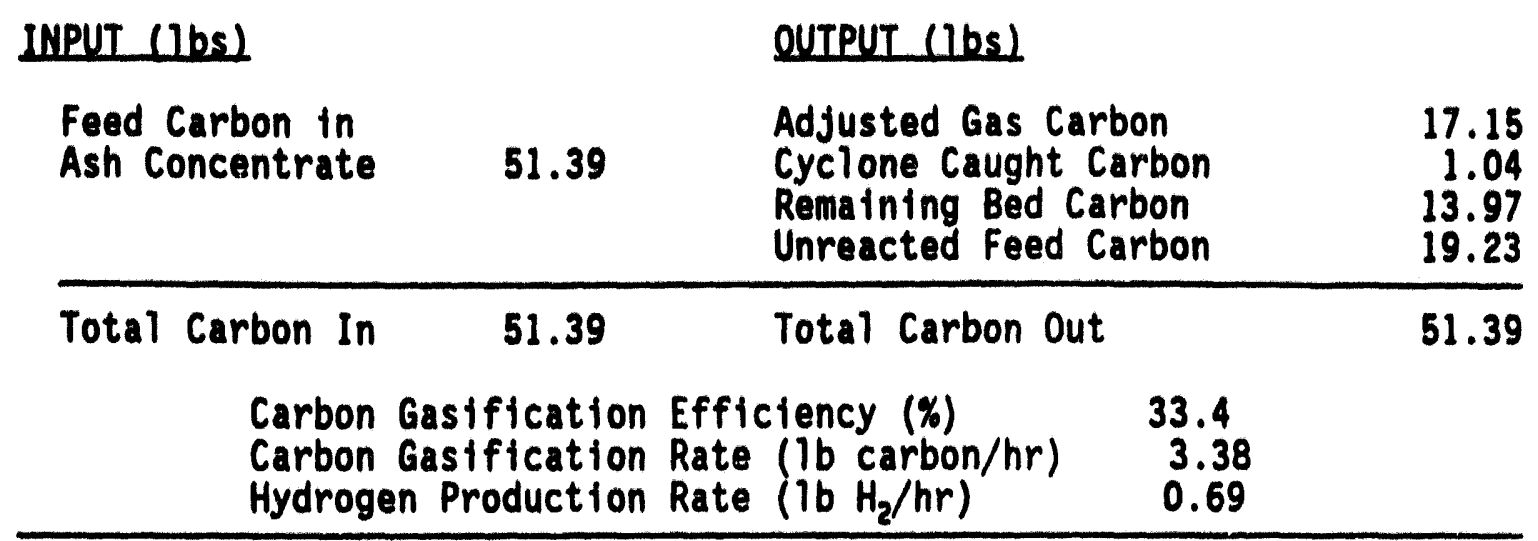

TABLE 3-37:

CARBON BALANCE FOR DECEMBER 20, 1990 GASIFICATION TEST

\begin{tabular}{|c|c|c|c|c|c|}
\hline NPUT 1 & 1bs) & & OUTPUT (16s) & & \\
\hline $\begin{array}{l}\text { Feed } \\
\text { Ash C } \\
\text { Bed C }\end{array}$ & $\begin{array}{l}\text { Carbon in } \\
\text { oncentrate } \\
\text { arbon }\end{array}$ & $\begin{array}{l}38.36 \\
24.72\end{array}$ & $\begin{array}{l}\text { Adjusted Gas } \\
\text { Cyclone Caugh } \\
\text { Remaining Bec }\end{array}$ & & $\begin{array}{r}32.1 \\
2.50 \\
28.48\end{array}$ \\
\hline Tota & Carbon In & 63.08 & Total Carbon & & 63.08 \\
\hline & $\begin{array}{l}\text { Carbon } G \\
\text { Carbon } G \\
\text { Hydrogen }\end{array}$ & $\begin{array}{l}\text { ation } \\
\text { ation } \\
\text { ction }\end{array}$ & $\begin{array}{l}\text { ency }(\%) \\
\text { ib carbon } / \mathrm{hr} \text { ) } \\
\text { Ib } \mathrm{H}_{2} / \mathrm{hr} \text { ) }\end{array}$ & & \\
\hline
\end{tabular}


As seen in Tables 3-36 and 3-37, the test with limestone bed achleved high gasification effictency as compared to sand bed test. This reflects the catalytic effect of 1 imestone bed, especially for low reactivity feed material such as ash residue.

\subsection{LONG-TERM SRC RESIDUES GASIFICATION TEST}

\section{SUBTASK 2.3: INDTRECT GASTFICATION OF SRC RESTDUES SRC RESIDUE GASIFICAIION IEST 10-8-92}

In this test, the gasifier was charged with 104 pounds of fresh 1 imestone and 83.8 pounds of bed material from test 10/02/92. The reactor was heated to $1550^{\circ} \mathrm{F}$ and kept at that temperature unt 11 all the 1 imestone was calcined to 1 ime. The $\mathrm{CO}_{2}$ evolution during the calcination process was continuously monitored by the gas chromatograph until the $\mathrm{CO}_{2}$ cuncentration was less than $0.5 \% \mathrm{~V} / \mathrm{v}$ dry basis. When all the 1 imestone was completely calcined to 1 ime, the SRC feed commenced. Total SRC feed to the gasifier over a 9-hour perlod was 182 pounds. The product gas production rate was measured by Tracer technique. Approximately 177.5 pounds of product gas was produced over this period. Iable 3-38 shows the preliminary mass balance for this test. Eiqure $3-13$ shows the average bed temperature for this test. The average bed temperature ranged between $1550^{\circ} \mathrm{F}$ to $1575^{\circ} \mathrm{F}$ throughout the test period.

Eigure 3-14 shows the temperature history for the pulse combustor chamber and exhaust as well as the fluidized bed temperature. As shown in Figure 9, the approach temperature (difference between exhaust temperature and bed temperature) is no more than $100^{\circ} \mathrm{F}$ for better part of the test indicating high heat transfer from the tube to the bed. The bed temperature along the height of the reactor was continuousiy measured. As shown in Eigure 3-15, the bed temperatures are all very close indicating very good fluidization.

Figure 3-16 shows the average product gas generation rate to be approximately $16 \mathrm{lbs} / \mathrm{hr}$. Finally, the product gas composition, shown in Figure 3-17, was fairly constant during the test, indicating steady-state operation. The average product gas composition is tabulated in Iable 3-39. Solid and 1iquid 
TABLE 3-38:

PRELLTMTNARY MASS BALANCE FOR IEST 10-8-92

\begin{tabular}{|l|c|}
\hline \multicolumn{1}{|c|}{ INPUT } & (1bs) \\
\hline Fresh Limestone & 104.2 \\
\hline Old Bed (Test 10/2/92) & 83.8 \\
\hline Feedstock & 182.0 \\
\hline Cooling Water in Ventuid Scrubber & 421.6 \\
\hline Steam & 363.0 \\
\hline TOTAL OUTPUT & 1154.6 \\
\hline & $(1 \mathrm{bs})$ \\
\hline Final Bed & 88.8 \\
\hline Bed Overflow & 77.8 \\
\hline Cyclone & 90.9 \\
\hline Venturi Scrubber Condensate & 610.2 \\
\hline F1lter Solids & 10.8 \\
\hline Product Gas & 177.5 \\
\hline CO generated during calcination & 45.8 \\
\hline TOTAL & 1101.8 \\
\hline Closure (\%wt/wt) & 95.4 \\
\hline
\end{tabular}




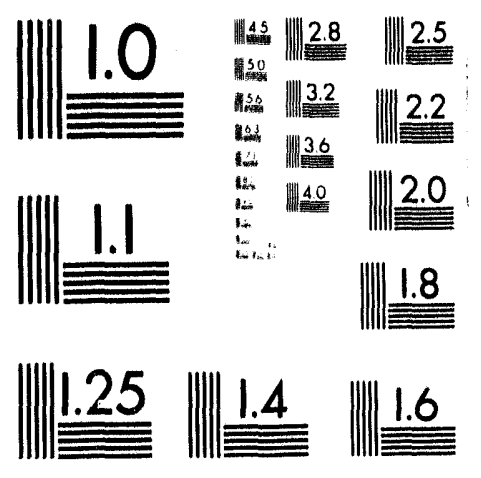



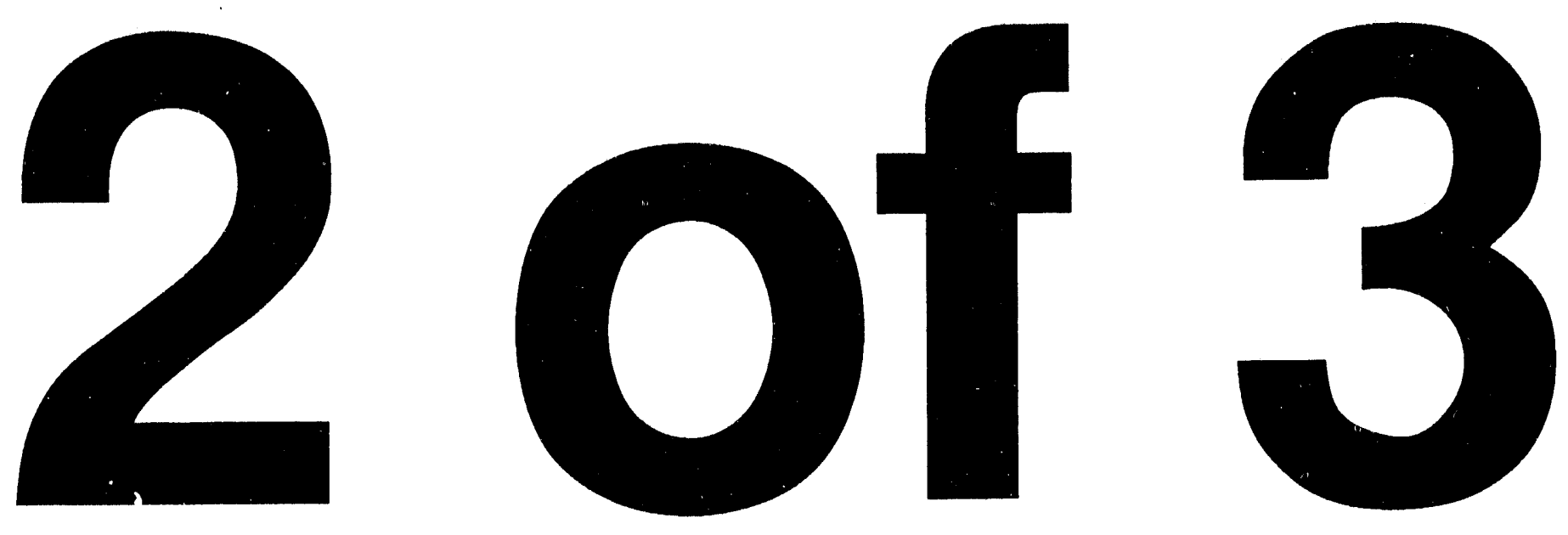


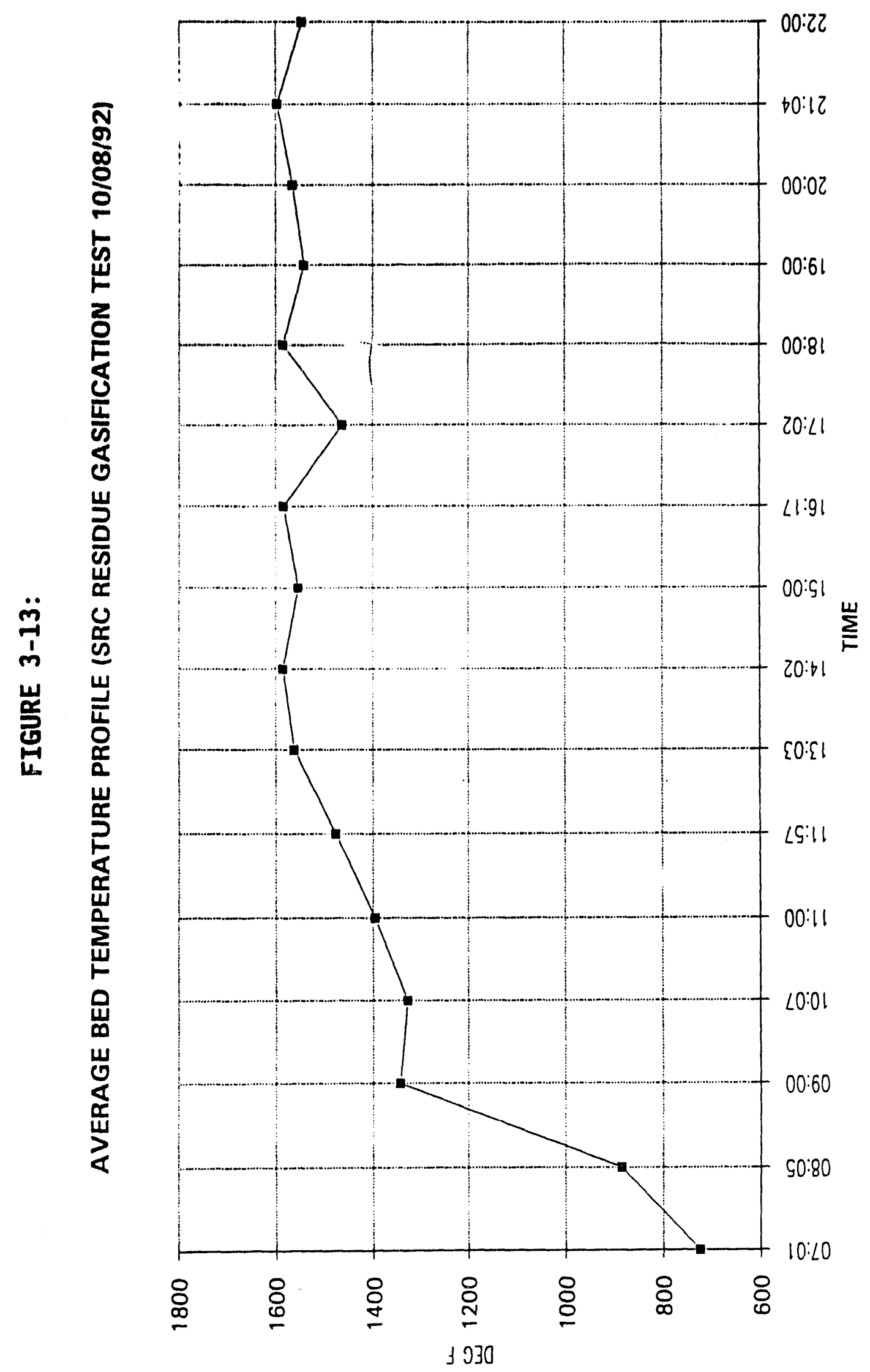




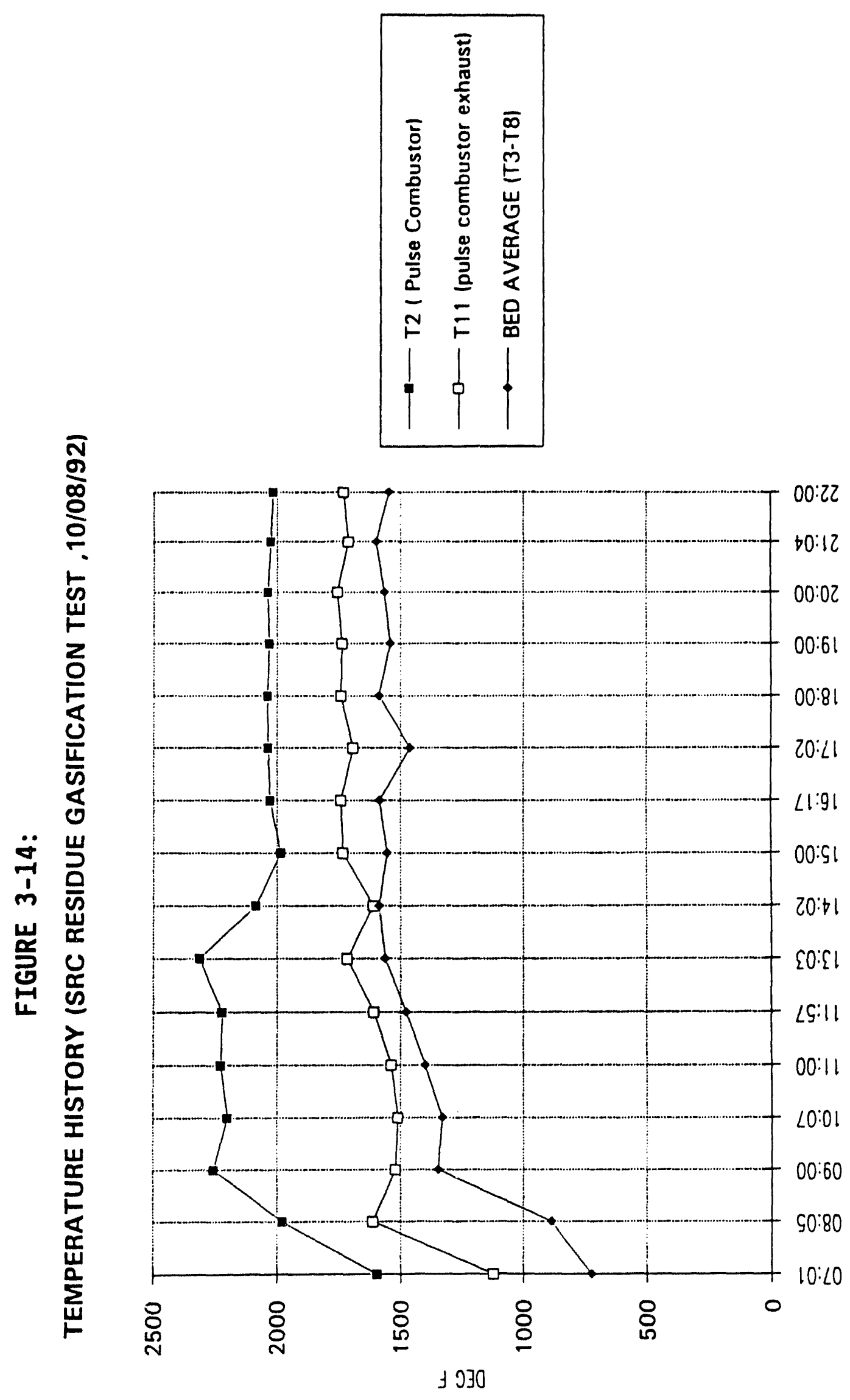



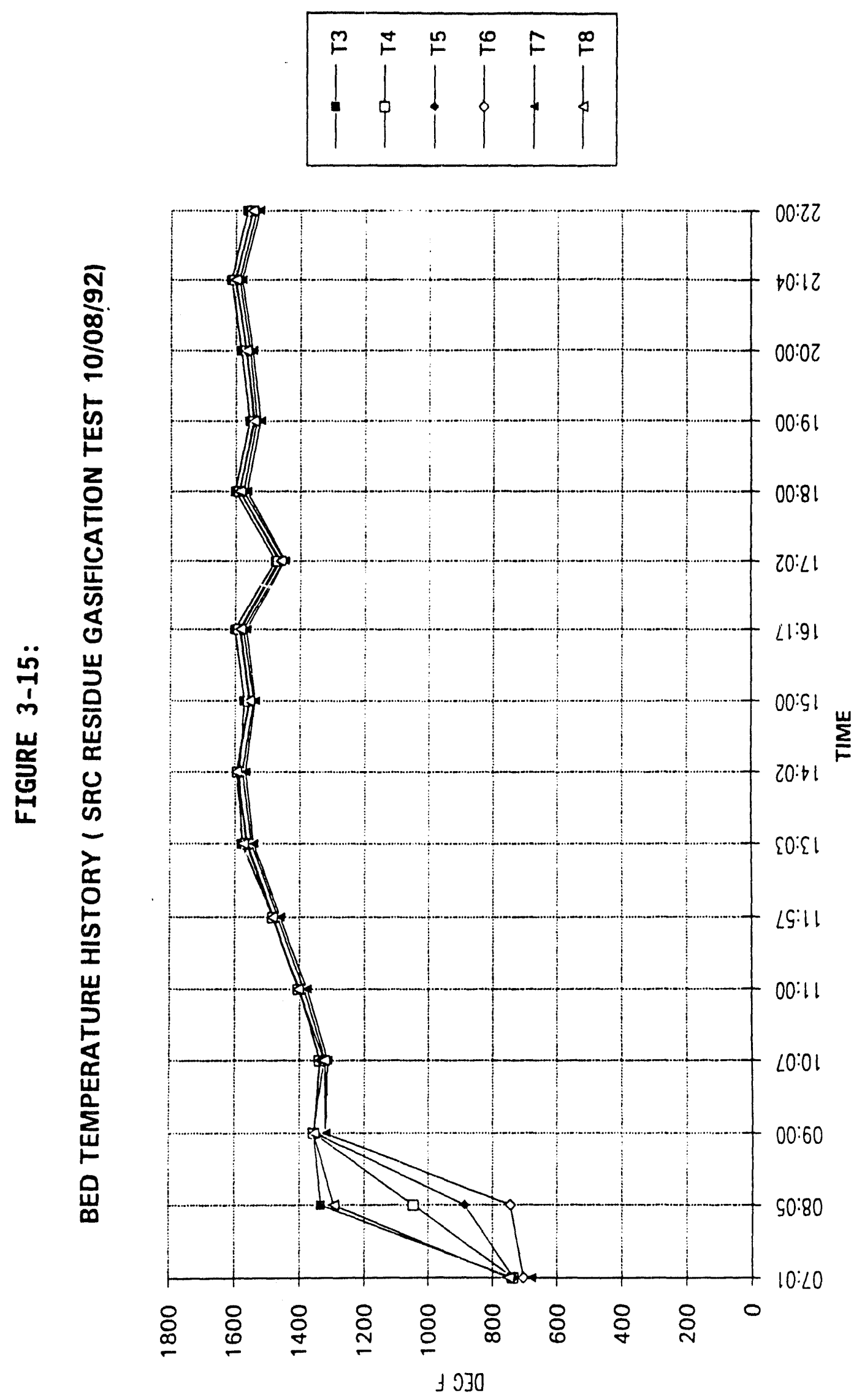


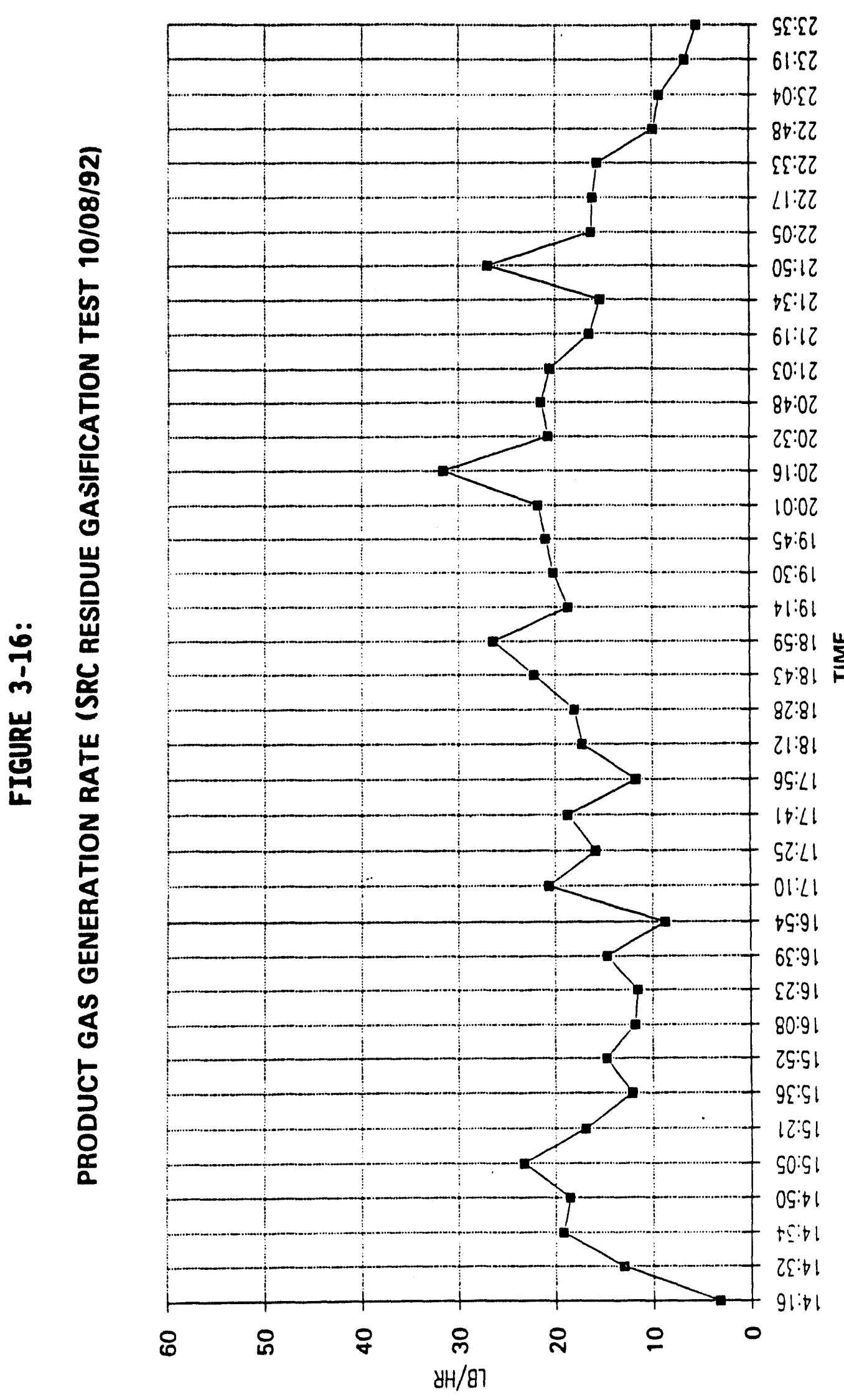



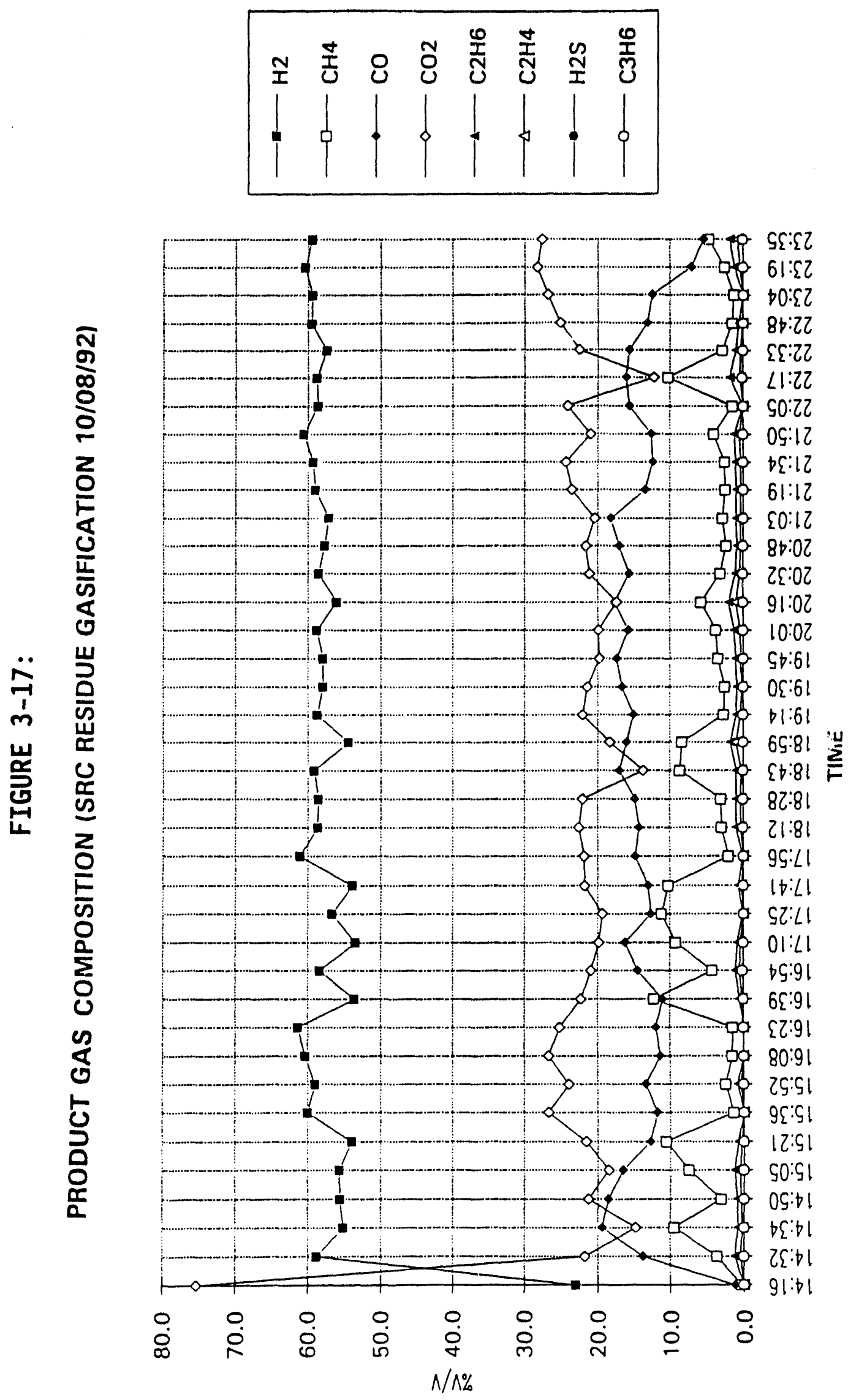
TABLE 3-39:

AVERAGE PRODUCT GAS COMPOSITION - TEST 10/8/92

\begin{tabular}{||l|c|}
\hline \multicolumn{1}{|c|}{ COMPONENT } & $\% \mathrm{~V} / \mathrm{V}$ \\
\hline Hydrogen & 57.0 \\
\hline Methane & 4.6 \\
\hline Carbon Monoxide & 14.0 \\
\hline Carbon Dioxide & 23.1 \\
\hline Ethane & 0.89 \\
\hline Ethylene & 0.35 \\
\hline Hydrogen Sulfide & 0.01 \\
\hline Propylene & 0.02 \\
\hline TOTAL & 100.0 \\
\hline
\end{tabular}


samples were also sent to Standard Laboratory for elemental analys is but were not recetved back from the laboratory as of this report.

Table 3-40 shows the carbon balance obtained for this gasification test. The table also lists the normalized carbon and material balances. Since the solids are directly measured and collected, whereas the gas production is calculated indirectly, the error in closure is attributed primarily to the gas production amount and, hence, this quantity is normalized to obtain a carbon balance. Based on the new quantities, the material balance is carried out once again and is listed in the table. As can be seen from the table, a carbon gasification efficiency of 65 percent is obtained for this test. This value is particularly low as compared to the char gasification efficiencies of the order 90 percent for a similar temperature range. The low values are obtained primarily because of the low reactivity of the residue as compared to char, which is considerably more reactive.

\subsection{DIRECT GASIFICATION OF SUBBITUMINOUS COALS}

Tests for the direct gasification of coal were initiated on January 17, 1991. The reactor was operated at an average temperature of $1390^{\circ} \mathrm{F}\left(754^{\circ} \mathrm{C}\right)$ with a limestone fluidized bed. Black Thunder coal was chosen as the feed material and was fed to the gasifier at an average rate of $16.9 \mathrm{lb} / \mathrm{hr}$. A total of 118 pounds of coal was gasified.

Chemical analysis for samples collected during the January 17 th coal gasification test were conducted by Standard Laboratories (SL) of Casper, Wyoming. The samples analyzed included the feed material, the original bed sample, the final bed sample and two cyclone catch samples. The operating parameters and averaged product gas analysis for the test are summarized in Table 3-41. Table 3-42 presents the overall material balance.

The SL proximate and ultimate analyses of the coal are listed in Table 3-43 together with the results of previous analysis for comparison. It can be seen that the two analyses are in agreement except for the moisture. This is probably due to the loss of moisture during the time of storage. The bed samples and cyclone samples were also analyzed by SL for their total carbon and mineral 
TABLE 3-40:

CARBON AND MATERIAL BALANCE SRC TEST NORMALIZED FOR CARBON BALANCE

\begin{tabular}{|l|r|r|r||}
\hline \multicolumn{1}{|c|}{ INPUT } & \multicolumn{1}{c|}{ C, LBS } & $\begin{array}{c}\text { C, LBS } \\
\text { NORMALIZED }\end{array}$ & $\begin{array}{c}\text { MASS, LBS } \\
\text { NORMALIZED }\end{array}$ \\
\hline LIMESTONE & & & 104.2 \\
\hline OLD BED MATERIAL & 3.06 & 3.06 & 83.8 \\
\hline SRC RESIDUE FEED & 91.36 & 91.36 & 182.0 \\
\hline $\begin{array}{l}\text { COOLING WATER IN VENTURI } \\
\text { SCRUBBER }\end{array}$ & & & 421.6 \\
\hline FLUIDIZATION STEAM & & & 363.0 \\
\hline TOTAL & 94.4 & 94.4 & 1154.6 \\
\hline & & & \\
\hline FINAL BED & 6.32 & 6.32 & 88.8 \\
\hline OVERFLOW & 5.54 & 5.54 & 77.8 \\
\hline CYCLONE CATCH & 17.19 & 17.19 & 90.9 \\
\hline VENTURI SCRUBBER CONDENSATE & 2.62 & 2.62 & 610.2 \\
\hline FILTER SOLIDS & 3.35 & 3.35 & 10.8 \\
\hline PRODUCT GAS & 57.84 & 59.40 & 179.3 \\
\hline CALCINATION EVOLVED CO & & & 45.9 \\
\hline TOTAL & 92.90 & 94.40 & 1103.6 \\
\hline ClOSURe, \% & 98.35 & 100.00 & 95.6 \\
\hline GasifiCation Efficiency, \% & 63.30 & 65.01 & \\
\hline
\end{tabular}


TABLE 3-41:

\section{OPERATION SUMMARY AND PRODUCT GAS ANALYSIS FOR JANUARY 17, 1991, TEST}

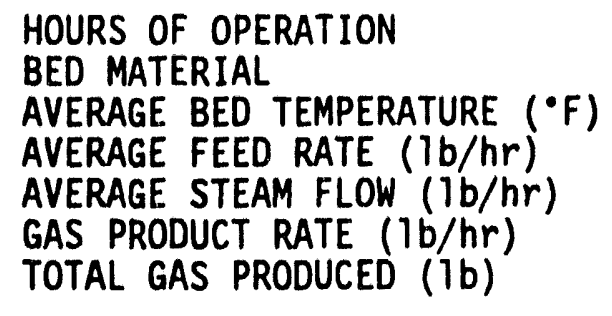

PRODUCT GAS ANALYSIS

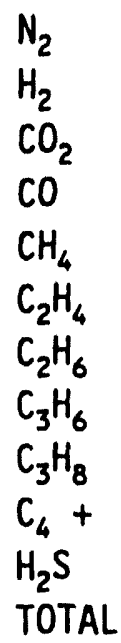

7 LIMESTONE 1390

16.9

28.3

24.7

172.7

DRY VOL. $(\%)$
55.59
28.35
12.22
3.13
0.32
0.15
0.05
0
0.05
0.14
100.00

TABLE 3-42:

MATERIAL BALANCE

(January 17, 1991)

INPUT (1bs)

\begin{tabular}{lc} 
Bed Original & 170 \\
Total Feed & 110.6 \\
Steam Input & 198 \\
\hline Total & 478.6
\end{tabular}

OUTPUT (1bs)

\begin{tabular}{lc} 
Bed Final & 152 \\
Cyclone Catch & 20.2 \\
Dry Product Gas & 172.7 \\
Water Condensed & 119 \\
\hline & \\
Total & 463.9 \\
Loss & 14.7
\end{tabular}


TABLE 3-43:

\section{EEED MATERTAL ANALYSIS}

\begin{tabular}{|c|c|c|c|c|}
\hline \multirow{2}{*}{$\begin{array}{c}\text { PROXIMATE ANALYSIS } \\
(W t . \%) \\
\end{array}$} & \multicolumn{2}{|c|}{$\begin{array}{l}\text { CURRENT ANALYSIS } \\
\begin{array}{c}(3 / 5 / 91) \\
\end{array}\end{array}$} & \multicolumn{2}{|c|}{$\begin{array}{l}\text { PREVIOUS ANALYSIS } \\
(6 / 19 / 90) \\
\end{array}$} \\
\hline & As Rec'd & Dry & As Rec'd & Dry \\
\hline $\begin{array}{l}\text { MOISTURE } \\
\text { ASH } \\
\text { VOLATILE MATTER } \\
\text { FIXED CARBON }\end{array}$ & $\begin{array}{r}19.30 \\
5.16 \\
35.93 \\
39.61 \\
\end{array}$ & $\begin{array}{r}6.40 \\
44.52 \\
49.08 \\
\end{array}$ & $\begin{array}{r}23.34 \\
5.48 \\
33.75 \\
37.43 \\
\end{array}$ & $\begin{array}{r}7.15 \\
44.03 \\
48.82 \\
\end{array}$ \\
\hline TOTAL & 100.00 & 100.00 & 100.00 & 100.00 \\
\hline HEATING VALUE (EItu/Ib) & 9174 & 11368 & 9312 & 12148 \\
\hline \multicolumn{5}{|l|}{$\begin{array}{l}\text { ULTIMATE ANALYSIS } \\
(W t . \%) \\
\end{array}$} \\
\hline $\begin{array}{l}\text { ASH } \\
\text { CARBON } \\
\text { HYDROGEN } \\
\text { SULFUR } \\
\text { NITROGEN } \\
\text { OXYGEN } \\
\text { CHLORINE }\end{array}$ & \multicolumn{2}{|c|}{$\begin{array}{r}6.40 \\
68.84 \\
4.55 \\
0.48 \\
1.02 \\
18.71 \\
<0.01 \\
\end{array}$} & \multicolumn{2}{|c|}{$\begin{array}{r}7.15 \\
69.66 \\
5.03 \\
0.46 \\
0.92 \\
16.78 \\
<0.01 \\
\end{array}$} \\
\hline TOTAL & \multicolumn{2}{|c|}{100.00} & \multicolumn{2}{|c|}{100.00} \\
\hline
\end{tabular}


carbonate carbon. The organic carbon was then calculated by the difference between the total and mineral carbon. The result of carbon content analysis is listed in Iable 3-44. Based on these data, a carbon balance was formed and the results summarized in Iable 3-45.

The gross carbon closure in Table 3.45 shows a positive discrepancy from 100 percent. This might be caused by several factors. First, the limestone bed was continuousiy decomposing, releasing carbon dioxide, thus increasing the car. bon content in the product gas. According to the mineral carbon analysis, this part of carbon accounts only for 3.4 pounds which is far less than the 28 pounds of difference between input and output carbon. There may be an additional error due to the measurement of tracer nitrogen used for calculating the product gas flow rate. A leak in the trace nitrogen line would cause significant errors in flow rate, thus increasing corresponding errors in the product gas flow rate. Finally, all errors in carbon analysis and gas analysis could sum up and result in a large error in the carbon balance. Since it was difficult to estimate the errors, the output carbon was adjusted by normalizing and based on the normalized value, the carbon gasification efficiency was calculated to be 85.4 percent. The liquid product yield was very low, and the carbon-based char yield was 14.6 percent.

The average hydrogen yield for this test was calculated as $0.27 \mathrm{lb} \mathrm{H}_{2}$ per pound of feed carbon. This corresponds to 48 SCF $\mathrm{H}_{2}$ per pound of feed carbon, or 74.6 percent of the theoretical hydrogen yield. The dry gas composition after adjustment of $\mathrm{CO}_{2}$ release from the bed material is listed in Iable 3-46.

The hydrogen yield of direct gasification of coal was compared with that of two-step gasification, i.e., first step of mild gasification of coal for production of liquid and char and second step of char gasification for production of hydrogen. This comparison was based on utilizing a limestone bed for both cases. The direct gasification yields 32.9 pounds of hydrogen per 100 pounds of coal carbon after $\mathrm{CO}$ shift to $\mathrm{H}_{2}$, while two-stage gasification yields 21.5 pounds of hydrogen per 100 pounds of feed carbon after the $c 0$ shift reaction. The lower hydrogen yield of the two-stage gasification was mainly due to the production of liquid and higher hydrocarbon gases. 
TABLE 3-44:

CARBON CONTENTS ANALYSIS FOR BED SAMPLES AND CYCLONE SAMPLES OF JANUARY 17, 1991 TEST (\%)

\begin{tabular}{lccc} 
& IOTAL CARBON & MINERAL CARBON & ORGANIC CARBON \\
ORIGINAL BED & 13.60 & 8.28 & \\
FINAL BED & 34.04 & 6.98 & 5.32 \\
CYCLONE AT 21:30 & 49.73 & 3.78 & 7.06 \\
CYCLONE AT 23:30 & 53.08 & 2.99 & 45.95 \\
\hline
\end{tabular}

TABLE 3-45:

ORGANIC CARBON BALANCE FOR COAL GASIFICATION TEST ON JANUARY 17, 1991

\begin{tabular}{llllc} 
INPUT (lbS) & & OUTPUT (IbS) & $\underline{\text { Gross }}$ & Normalized \\
STARTING BED & 23.12 & BED FINAL & 21.34 & 21.34 \\
TOTAL FEED CARBON & $\underline{61.18}$ & CYCLONE CHAR & 10.38 & 10.38 \\
TOTAL INPUT & $\underline{84.30}$ & PRODUCT GAS & 86.15 & 52.58 \\
& & & & \\
& TOTAL OUTPUT & $\underline{117.87}$ & $\underline{84.30}$ \\
& CARBON CLOSURE & $139.82 \%$ & $100.00 \%$ \\
& & GAS YIELD (\%) & 90.1 & 85.4 \\
& LIQUID YIELD (\%) & 0 & 0 \\
& CHAR YIELD (\%) & 9.9 & 14.6 \\
\hline
\end{tabular}


TABLE 3-46:

DRY PRODUCT GAS ANALYSIS FOR JANUARY 17, y991 TEST

AFTER ADJUSTMENT FOR $\mathrm{CO}_{2}$ RELEASED FROM THE BED

\begin{tabular}{lr} 
COUPONENTS & VOL. \% \\
\hline $\mathrm{H}_{2}$ & 56.592 \\
$\mathrm{CO}_{2}$ & 27.065 \\
$\mathrm{CO}$ & 12.441 \\
$\mathrm{CH}_{4}$ & 3.189 \\
$\mathrm{C}_{2} \mathrm{H}_{4}$ & 0.329 \\
$\mathrm{C}_{2} \mathrm{H}_{6}$ & 0.151 \\
$\mathrm{C}_{3} \mathrm{H}_{6}$ & 0.048 \\
$\mathrm{C}_{3} \mathrm{H}_{8}$ & 0 \\
$\mathrm{C}_{4}-i$ & 0.010 \\
$\mathrm{C}_{4}-n$ & 0.030 \\
$\mathrm{H}_{2} \mathrm{~S}$ & 0.143 \\
& \\
TOTAL & 100.00 \\
\hline
\end{tabular}


A chemical analysis of the solid samples from the test of January 17, 1991, was performed by Truesdail Laboratories, Tustin, California. The purpose of this analysis was to check heavy metal pollutants in the bed sample and the char/ash collected in the cyclone. A TCLP extraction analysis was performed for eight metals on one bed sample and one cyclone sample. The results are listed in Table 3-47.

TABLE 3-47:

iclp extraction of heavy Metal Pollutants

\begin{tabular}{|c|c|c|c|c|c|}
\hline \multirow[b]{2}{*}{ METAL } & \multirow[b]{2}{*}{ METHOD } & \multicolumn{4}{|c|}{ CONCENTRATION $(M G / L)$} \\
\hline & & $\begin{array}{l}\text { TCLP } \\
\text { LIMIT } \\
\end{array}$ & $\begin{array}{c}\text { DETECTION } \\
\text { LIMIT } \\
\end{array}$ & $\begin{array}{c}\text { BED } \\
\text { SAMPLE }\end{array}$ & $\begin{array}{l}\text { CYCLONE } \\
\text { SAMPLE } \\
\end{array}$ \\
\hline Arsenic & SM307A & 5.0 & 0.013 & ND & ND \\
\hline Barium & EPA 200.7 & 100 & 0.1 & 1.6 & 1.1 \\
\hline Cadmium & EPA 200.7 & 1.0 & 0.1 & ND & ND \\
\hline Chromium & EPA 200.7 & 5.0 & 0.1 & ND & ND \\
\hline Lead & EPA 200.7 & 5.0 & 0.1 & ND & ND \\
\hline Mercury & EPA 245.1 & 0.2 & 0.003 & ND & ND \\
\hline Selenium & SM $323 A$ & 1.0 & 0.013 & ND & ND \\
\hline Silver & EPA 200.7 & 5.0 & 0.1 & ND & ND \\
\hline
\end{tabular}

ND = Not Detected (below detection 1 imit).

It can be seen from Table 3-47 that for all the metals except barium, concentrations in the extraction are lower than the detection limits. Even for barium, the detected concentrations of 1.6 and 1.1 milligrams per 1 iter in the bed and cyclone samples, respectiveiy, are well below the allowed TCLP limit of 100 milligrams per liter.

\subsection{BITUMINOUS COAL DEVOLATILIZATION AND GASIFICATION}

Bituminous coals have a different chemistry than chars or residues and depend on the history of the coal formation. Depending on the specific nature of the macerals and mineral content and types, a large quantity of these coals 
have a caking tendency. The organics, when heated to a particular temperature range $\left(600-700^{\circ} \mathrm{F}\right)$, devolatilize and form a liquid coating over the coal surface and the coal becomes plastic. In combustion processes, the duration of this phase is extremely short due to the oxidative atmosphere. This is not so in the case of steam-reforming processes which have a reducing atmosphere. This results in agglomeration of the coal particles when the plasticized and swollen coal particles come into contact, especially in fluidized and entrained bed gasifiers. Agglomeration results in the formation of solid lumps which render the fluidization or entrained flow ineffective. Therefore, techniques are required to either eliminate the caking property or reduce the plastic duration of the bituminous coal in gasification systems.

To overcome the caking problem during the steam reforming of caking coals, various approaches have been investigated. Of the various alternatives, oxidation of caking coal at low temperature seems the best. Oxidation can be achieved by various routes; for example, acid treatment, ${ }^{(6,7)}$ acetylation, ${ }^{(8)}$ natural weathering, ${ }^{(9)}$ and mild oxidation. $(10,11)$ of all the alternative oxidation methods, partial oxidation appears to be the most viable route to efficiently and economically pretreat the bituminous coal in a controlled industrial environment.

The pretreatment of caking coals by oxidation process investigated by other researchers is found to be a time-intensive approach. It has been established that the addition of inorganic compounds significantly reduces the thermoplasticity of coal. ${ }^{(12,13)}$ MTCI initially intended to incorporate an oxidation step with impregnation of coal with an inorganic catalyst to diminish the caking properties of coal. Using a soluble calcium compound as the catalyst would also help absorb the high sulfur content of the bituminous coals. For example, pretreating with calcium acetate solution and then drying the coal in a preheater was considered. However, this method of treatment would be costly and alternative methods were investigated based on a literature search.

L.D. Schmidt, ${ }^{(14)}$ in Chemistry of Coal Utilization (H.H. Lowry, ed, 1945, Vol. 1, Ch. 18, pp. 627-696), presents an excellent summary of coal oxidation vs. temperature, particle size and partial pressure of oxygen: (i) For every $10^{\circ} \mathrm{C}$ $\left(18^{\circ} \mathrm{F}\right)$ rise in temperature, the rate of oxidation of $\mathrm{coal}$ increases by a factor 
of 2.2 ; (ii) The rate increases to the power of 0.61 of the oxygen concentration; and (iii) It increases proportionally to the cube root of the specific surface area of coal (deceasing particle size). These observations suggested that pretreating the coal by preheating to $600^{\circ} \mathrm{F}$ with flue gas containing less than 3 to 4 percent oxygen in a fluidized bed would be an effective way to decake the coal, thereby preventing it from agglomerating in the fluidized bed gasifier. Various methods of feeding bituminous coal to an indirectly heated, fluidized bed gasifier were therefore investigated.

The first step towards preconditioning was to establish the optimum conditions for sufficient preoxidation of the coal in order to reduce the Free Swelling Index (FSI) to around one. FSI is a measure of the caking tendency of coals. An FSI below 1 is necessary for preventing the agglomeration of the coal in the fluid bed during gasification. It has been established by various researchers $(9,10,11)$ that time duration and temperature of preoxidation are the controlling parameters for achieving low FSI values.

In order to evaluate the residence times and temperature necessary for preoxidation, MTCI performed a series of tests varying the residence times from one (1) to three (3) seconds and temperatures from $400^{\circ}$ to $600^{\circ} \mathrm{F}$ using air plus nitrogen as conveying gases in a U-tube preireater. Figure 3-18 is a schematic of the U-tube (Short Residence Time) preheater. In this method coal was educted by using motive air into the $U$-tube preconditioning column. The coal/air mixture was heated indirectly to $600^{\circ} \mathrm{F}$ by the flue gas from the pulse combustor. The coal/air mixture was then was collected by a high efficiency cyclone and sent to an outside laboratory for i.ee Swelling Index (FSI) analysis. Iable 3-48 gives the results of this short residence time pretreatment. Pulverized Pittsburgh No. 8 coal was used as feed. The feed coal had an FSI of 7.5 which was quite high. Most IIlinois, Indiana and Kentucky coals have an FSI between 4 to 6 . The pulverized Pittsburgh coal was pretreated to yield an FSI of 2.5 in less than two seconds at $600^{\circ} \mathrm{F}$. The high-temperature operation definitely played an important role here. Seki et al. ${ }^{(10,11)}$ reported a similar decrease at $200^{\circ} \mathrm{F}$ in about 6 hours. Natural weathering, on the other hand, takes about 250 days $^{(9)}$ to achieve the same FSI level. This clearly shows the advantages of high-temperature 
TO INCINERATOR

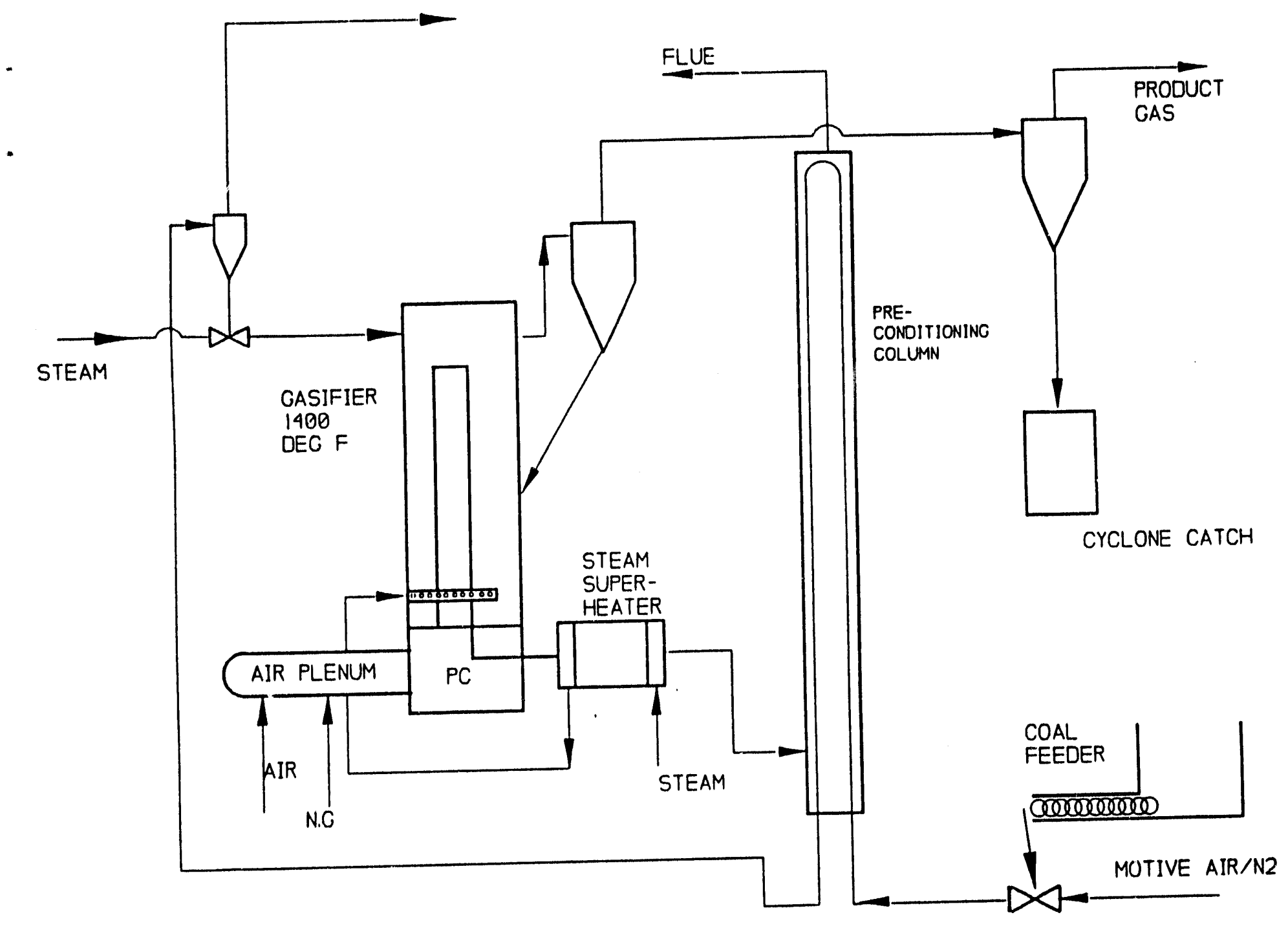

FIGURE 3-18: BITUMINOUS COAL GASIFIER WITH SHORT RESIDENCE TIME PREHEATER 


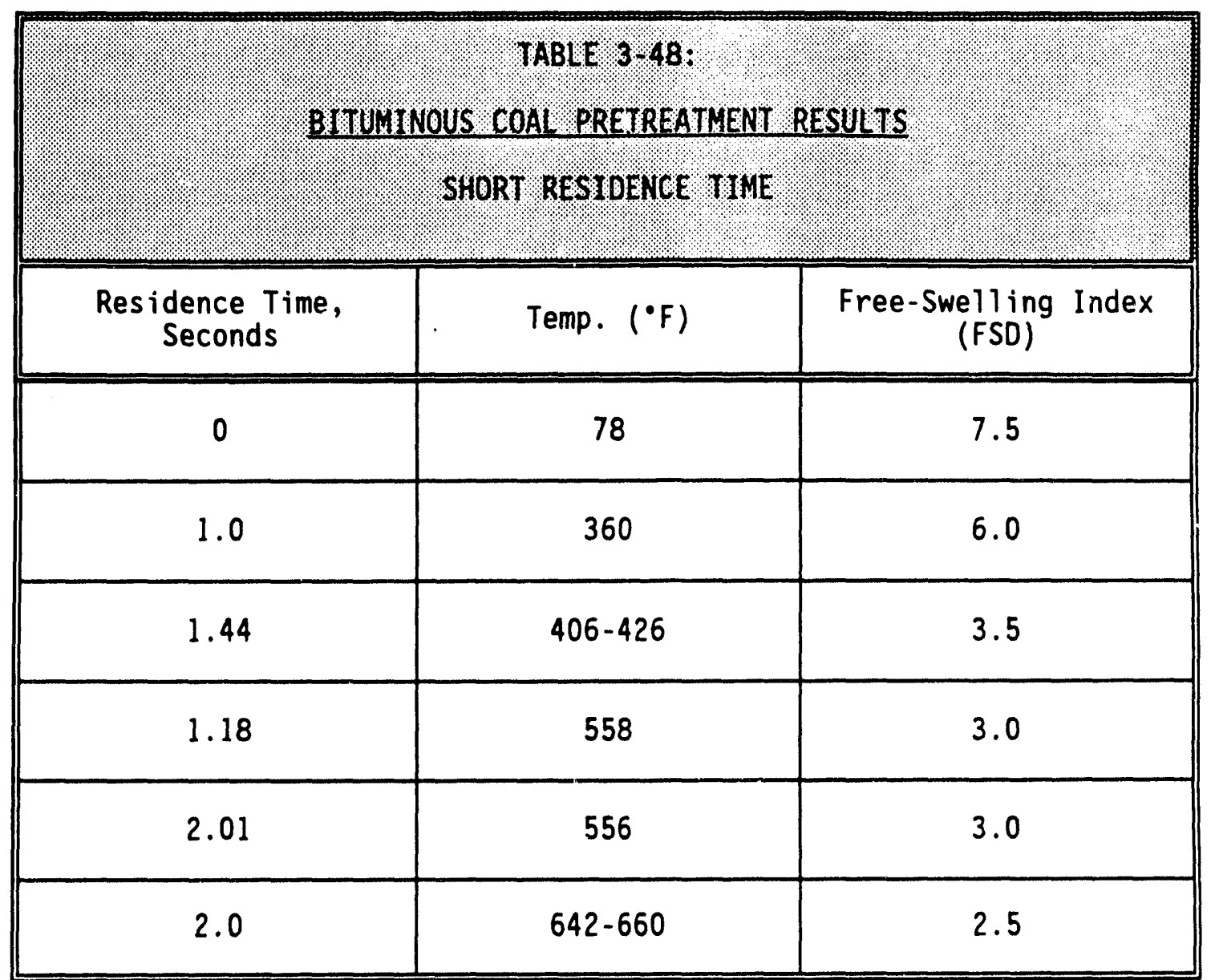


oxidation for pretreatment. The oxidation time also depends on the size of the coal. If coarser coal sizes are used the preheating time for pretreatment will be longer. For the bench-scale gasifier tests, it was difficult to use coarse coals. At larger scales, the fluidized bed preheater system should perform well even with coarser coals.

For these initial tests, the pulverized coal was educted into the U-tube pre-conditioning column using air as the transport medium. Although this entrained flow method would be effective for conveying the pulverized coal, it would be much less effective for coarser coals and would therefore not be economically practical for a larger scale commercial unit, especially under higher pressure operation. A fluidized bed method for pre-oxidation and transport to the gasifier could be applied more effectively to a commercial-sized system using a separate vessel for the pre-oxidation stage.

The tests confirmed that there is a sufficient amount of sensible heat in the pulse combustor flue gas existing the superheater to pretreat the caking coal so that the FSI can be reduced to less than 1.0. In a commercial-size gasifier about 20 percent of the energy input is available in the flue gas as waste heat and the flue gas mass flow rate is of the same order as the mass flow rate of coal. Hence, if the flue gas is available at $800^{\circ} \mathrm{F}$, It may be able to preheat the coal to about $400^{\circ} \mathrm{F}$. But in the bench scale, the heat losses are very high and the flue gas produced is five times the coal input to the reactor and, hence, only a fraction of the flue gas could be used for preheating the coal.

In this context, the $P C$ flue gas from the superheater is passed onto the pre-conditioning fluidized bed vessel as shown in Figure 3-19. The flue gas will have sufficient sensible heat and oxygen content to pre-treat the coal.

For the pretreatment/gasification tests, a fluidized bed batch processing technique was used to produce sufficient quantities of non-caking vituminous coal for further gasification. Three such batch tests were conductad to produce preconditioned coal. 


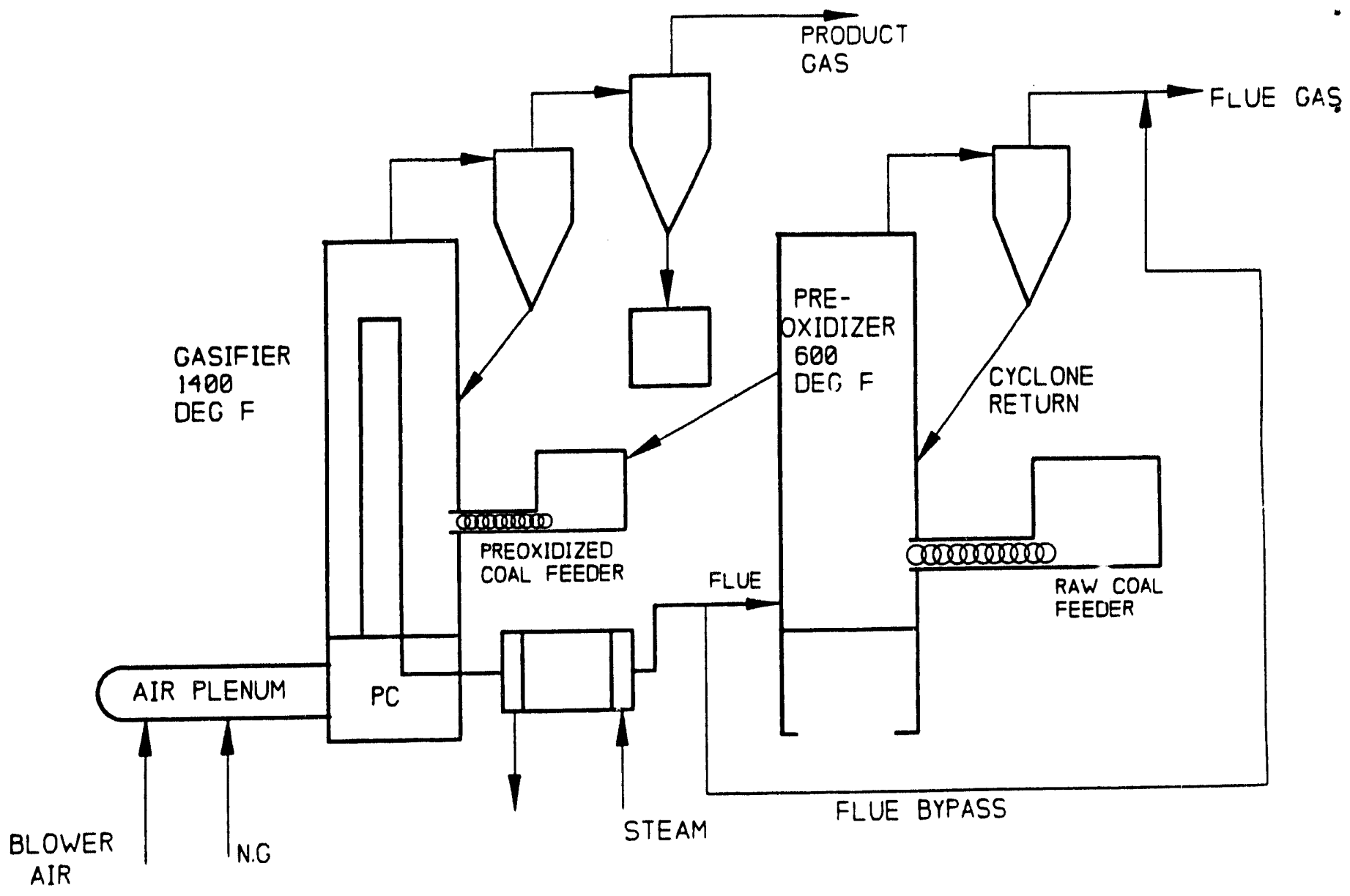

FIGURE 3-19: BITUMINOUS COAL PREOXIDIZER/GASIFIER 
In the first test, the preconditioning fluidized bed vessel was charged with 85 pounds of coal and 111 pounds of 7 imestone. The mixture was initially fluidized using air/nitrogen mixture and heated via the $U$-tube. When the temperature of the preoxidizer exceeded $200^{\circ} \mathrm{F}$ the switch was made from air $/ \mathrm{N}_{2}$ to flue gas direct heating. The oxygen concentration in the flue gas was approximately 3.4 percent $\mathrm{v} / \mathrm{V}$ on a dry basis. The oxidizer was heated to $580^{\circ} \mathrm{F}$ and kept at that temperature for 3 to 4 hours. The oxidized material from the preoxidizer was removed and fed to the gasifier via a screw feeder.

In the second test, the preoxidizer was charged with 119.8 pounds of caking coal and oxidized over a 5-hour period at an average temperature between $500^{\circ} \mathrm{F}$ $600^{\circ} \mathrm{F}$. The oxygen content of the oxidizing flue gas was between 3 to 4 percent $v / v(d r y)$.

In the third and last test, 80 pounds of fresh coal were oxidized between $550^{\circ} \mathrm{F}-750^{\circ} \mathrm{F}$ for 4 to 5 hours with the flue gas oxygen concentration ranging from 3 to 4 percent $v / v$ (dry).

\section{FLUIDIZED BED PREOXIDATION TEST RESULTS}

Iable 3-49 7 ists the FSI for the batch processed coal after preoxidation. It should be noted here that the temperature and time shown do not include the initial preheating and post cooling times. Preoxidation of the caking coal continues during these time periods as well. The reported FSI is for the final preconditioned coal. As compared to the FSI reduction time observed during the circulating bed tests, the decrease over a 5 -hour period is only twice as much as obtained in about 2 to 3 seconds in the previous tests. This can be attributed to the fact that the swelling properties of caking coals decrease rapidly during initial period of time and remain practically unchanged afterwards as also observed by Seki et al ${ }^{(8)}$ and Huggins et al. (9) 


\section{TABLE 3-49:}

\section{Bituminous Coal Pretreatment Results}

\begin{tabular}{||c|c|c||}
\hline HOURS OF PREOXIDATION & TEMPERATURE ('T) & FREE-SWELIING INOEX IFST \\
\hline Test 1: 4 hours & $570-580$ & 0.5 \\
\hline Test 2: 5 hours & $500-550$ & 1.0 \\
\hline Test 3: 5 hours & $550-750$ & $?$ \\
\hline
\end{tabular}

\subsection{GASIFICATION OF PREOXIDIZED COAL}

As described earlier, the gasification and preoxidation tests were conducted simultaneously for a few sets. The preoxidized coal from one test was used as feed for gasification in the next test. The preoxidized coal for the first test was obtained by heating a lime bed in the gasifier. Three sets of tests were conducted for gasification. The results of these tests are discussed in the following paragraphs.

\section{PREOXIDIZED CAKING COAL GASIFICATION TEST \#1}

Approximately 196.6 pounds of feedstock fed to the gasifier at a rate of $39.3 \mathrm{lb} / \mathrm{hr}$. The feed coal had an FSI of 0.5 . The average bed temperature throughout the test was $1427^{\circ} \mathrm{F}$. Table 3-50 shows the mass balance for this test. Figure 3-20 shows the product gas composition for the test run. Table 3-51 presents the average gas composition for the test run.

Figure 3-21 shows the product gas production rate for the test. The average product gas production rate is approximately $14 \mathrm{lb} / \mathrm{hr}$. Figure 3-22 shows the temperature history for pulse combustion chamber, $P C$ exit, and average bed temperature. 
TABLE 3-50:

MASS BALANCE SUMMARY FOR TEST \#1

(AVERAGE TEMPERATURE $1427^{\circ} \mathrm{F}$ )

\begin{tabular}{||l|c||}
\hline \multicolumn{1}{|c|}{ INPUT } & LBS \\
\hline LIMESTONE & 169.0 \\
\hline PREOXIDIZED COAL & 84.9 \\
\hline LIMESTONE AND COAL MIXTURE & 117.7 \\
\hline COOLING WATER IN VENTURI SCRUBBER & 331.0 \\
\hline FLUIDIZATION STEAM & 141.0 \\
\hline TOTAL OUTPUT & 837.6 \\
\hline & LBS \\
\hline FINAL BED & 106.4 \\
\hline CYCLONE CATCH & 112.2 \\
\hline VENTURI SCRUBBER CONDENSATE & 489.0 \\
\hline FILTER SOLIDS & 17.8 \\
\hline PRODUCT GAS & 120.4 \\
\hline TOTAL & 845.8 \\
\hline CIOSURE, \% & 99 \\
\hline
\end{tabular}




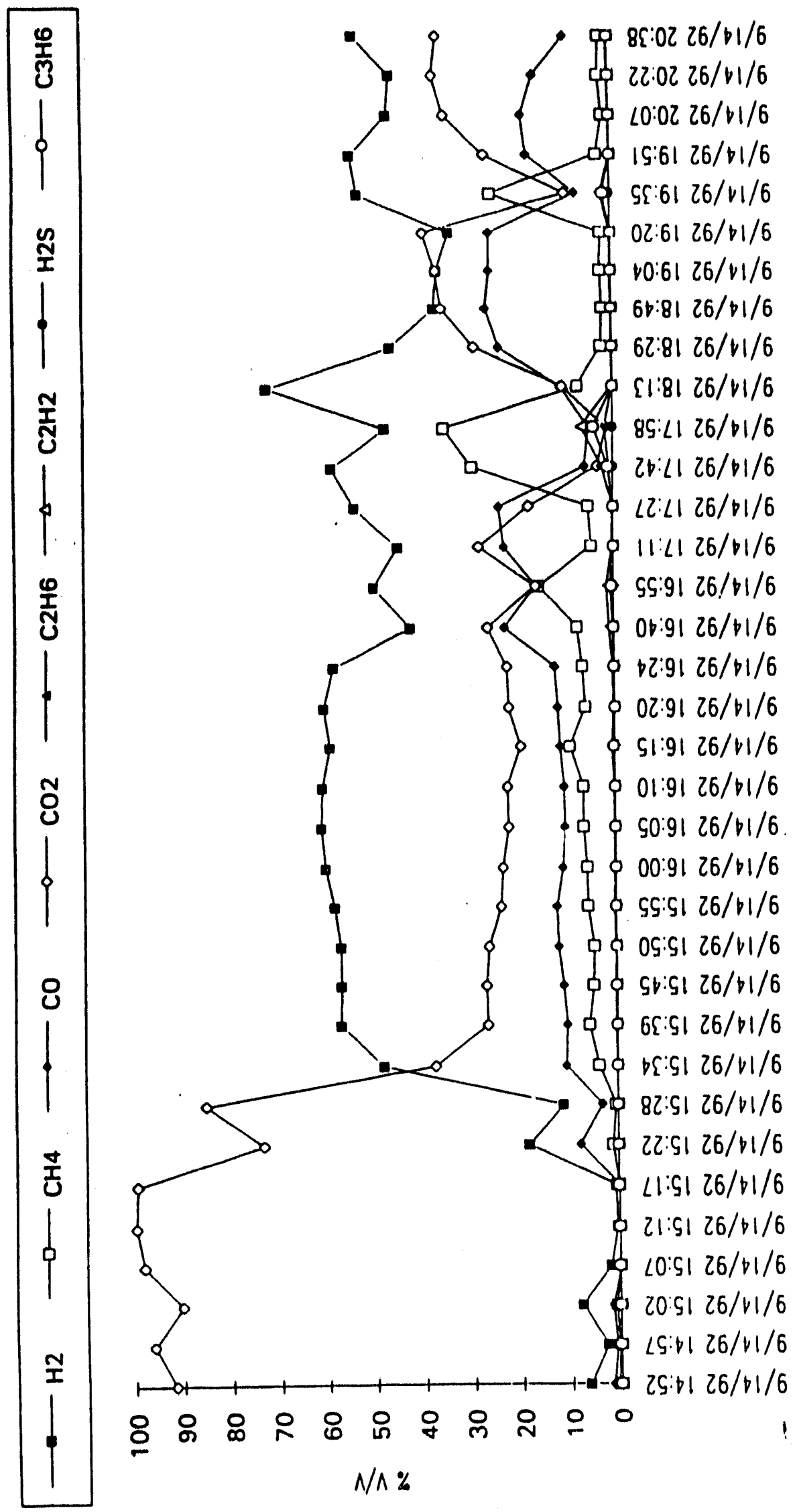

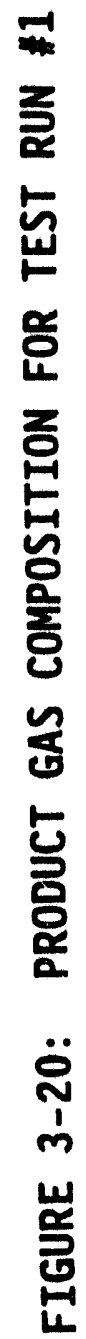


TABLE 3-51:

average Propuct gas Composttion. TEST $\# 1$

\begin{tabular}{||l|c|}
\hline | & \% V/N \\
\hline HYDROGEN & 58.67 \\
\hline METHANE & 6.09 \\
\hline CARBON MONOXIDE & 11.3 \\
\hline ETHANBON DIOXIDE & 23.4 \\
\hline ETHYLENE & 0.29 \\
\hline HYDROGEN SULFIDE & 0.17 \\
\hline PROPYLENE & 0.05 \\
\hline TOTAL & 0.03 \\
\hline
\end{tabular}




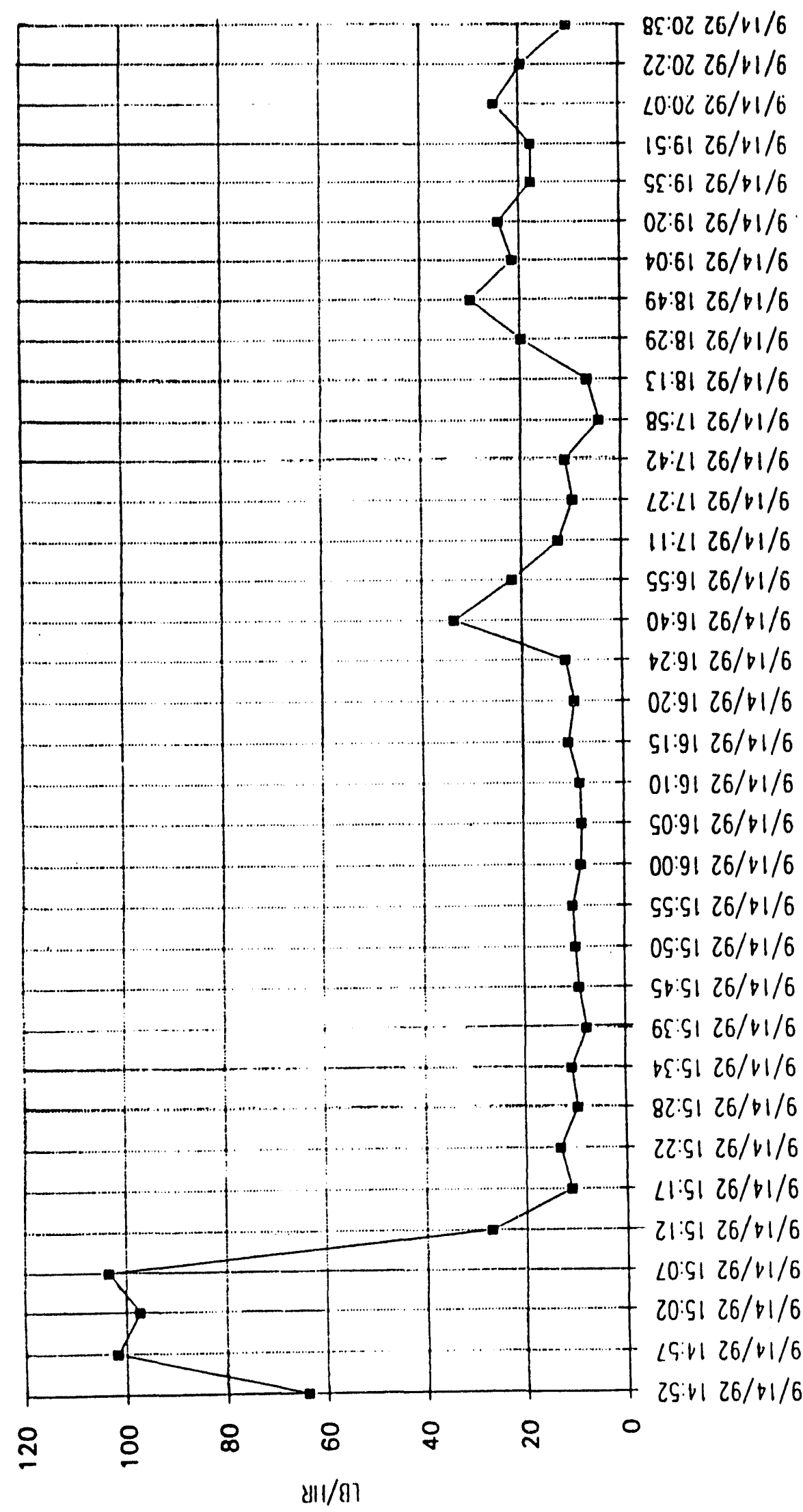

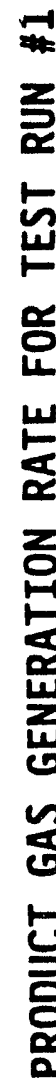




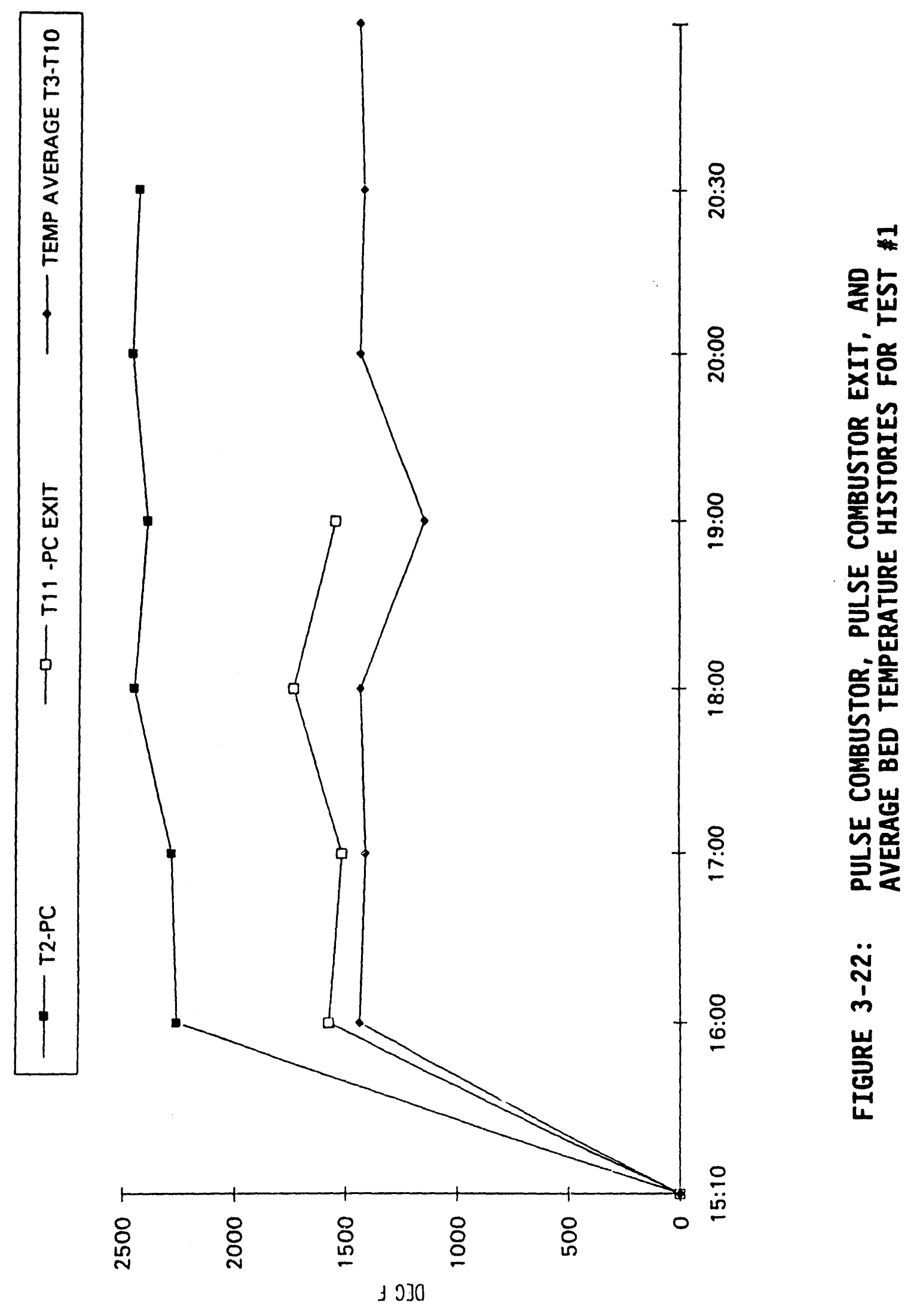




\section{PREOXIDIZED CAKING COAL GASIFICATION TEST \#2}

In this test the gasifier was charged with 109 pounds of old bed material and 29 pounds of cyclone material from Test \#1, to make up the bed above the Utubes. The oxidized coal was mixed with 80 pounds of cyclone catch from Test \#1 and fed to the gasifier. Adding the cyclone catch has two advantages: 1) It reduces FSI, and 2) Recycles the carbon in cyclone solid to gasifier, and hence, increases carbon gasification efficiency. In a commercial application the cyclone catch will be recycled to the gasifier directly. This was not feasible in a bench-scale mocle1. Table 3-52 shows the mass balance for this test. A mass balance closure of 96 percent is obtained.

Figure 3-23 shows the average bed temperature history. As shown in the figure, the bed temperature climbed to $1600^{\circ} \mathrm{F}$ and stayed at approximately $1600^{\circ} \mathrm{F}$ over the entire test period. Figure 3-24 shows the bed temperature for this test. As it shows, the bed temperatures are fairly close to each other showing a good fluidization. Figure 3-25 shows the product gas compositions for this test. Table 3-53 shows the average product gas composition for the Test 9-22-92. Figure 3-26 shows the product gas generation over the test period. The average product gas flow rate was $15-20 \mathrm{lbs} / \mathrm{hr}$. The spike at $17: 56$ was due to surge in feed rate, due to incorrect feeder setting.

\section{PREOXIDIZED CAKING COAL GASIFICATION TEST \#3}

The gasifier was charged with 200 pounds of fresh 1 imestone heated to $1500^{\circ} \mathrm{F}$ and maintained at that temperature for approximately 4 to 5 hours until all the limestone was calcined to lime. During the calcination process, the $\mathrm{CO}_{2}$ concentration (using $\mathrm{GC}$ ) was measured. The $\mathrm{CO}_{2}$ concentration dropped to less than 0.5 percent $\mathrm{V} / \mathrm{v}$ indicating that the calcination process was completed. It is important to calcine initially the limestone to lime completely so that $\mathrm{CO}_{2}$ concentration during gasification can be measured separately.

The oxidized coal was mixed with equivalent amount of cyclone solids (Test 9-22-92) and the remaining feedstock from Test 9-22-92 (122.4 1bs). This mixture was fed to the gasifier over a period of 6 hours. The average bed temperature was maintained at approximately $1560^{\circ} \mathrm{F}$, as shown in Fiqure 3-27. 
TABLE 3-52:

MASS BALANCE SUMMARY FOR TEST \#2

(AVERAGE TEMPERATURE $1600^{\circ} \mathrm{F}$ )

\begin{tabular}{|l|c|}
\hline \multicolumn{1}{|c|}{ INPUT } & LBS \\
\hline INITIAL BED MATERIAL & 109.0 \\
\hline CYCLONE BED MAKE-UP & 29.2 \\
\hline $\begin{array}{l}\text { FEEDSTOCK: PREOXIDIZED COAL AND } \\
\text { CYCLONE CATCH MIXTURE }\end{array}$ & 199.8 \\
\hline COOLING WATER IN VENTURI SCRUBBER & 417.5 \\
\hline FLUIDIZATION STEAM & 282.0 \\
\hline TOTAL OUTPUT & 1037.5 \\
\hline & LBS \\
\hline FINAL BED & 67.4 \\
\hline CYCLONE CATCH & 167.8 \\
\hline VENTURI SCRUBBER CONDENSATE & 589.1 \\
\hline FILTER SOLIDS & 23.8 \\
\hline PRODUCT GAS & 148.0 \\
\hline TOTAL & 996.1 \\
\hline CIOSURE, \% & 96 \\
\hline
\end{tabular}




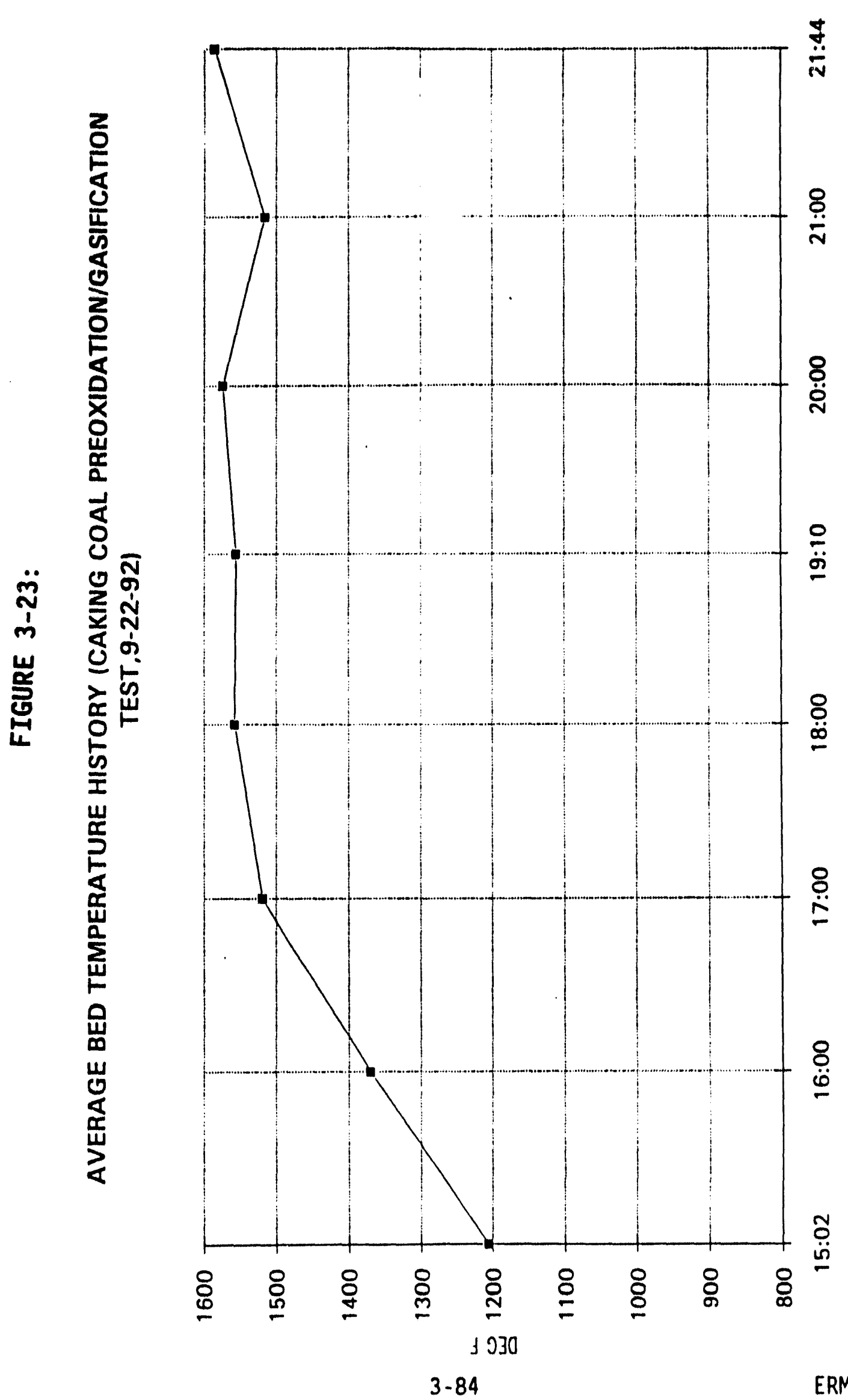

ERMH-39F . 3B 

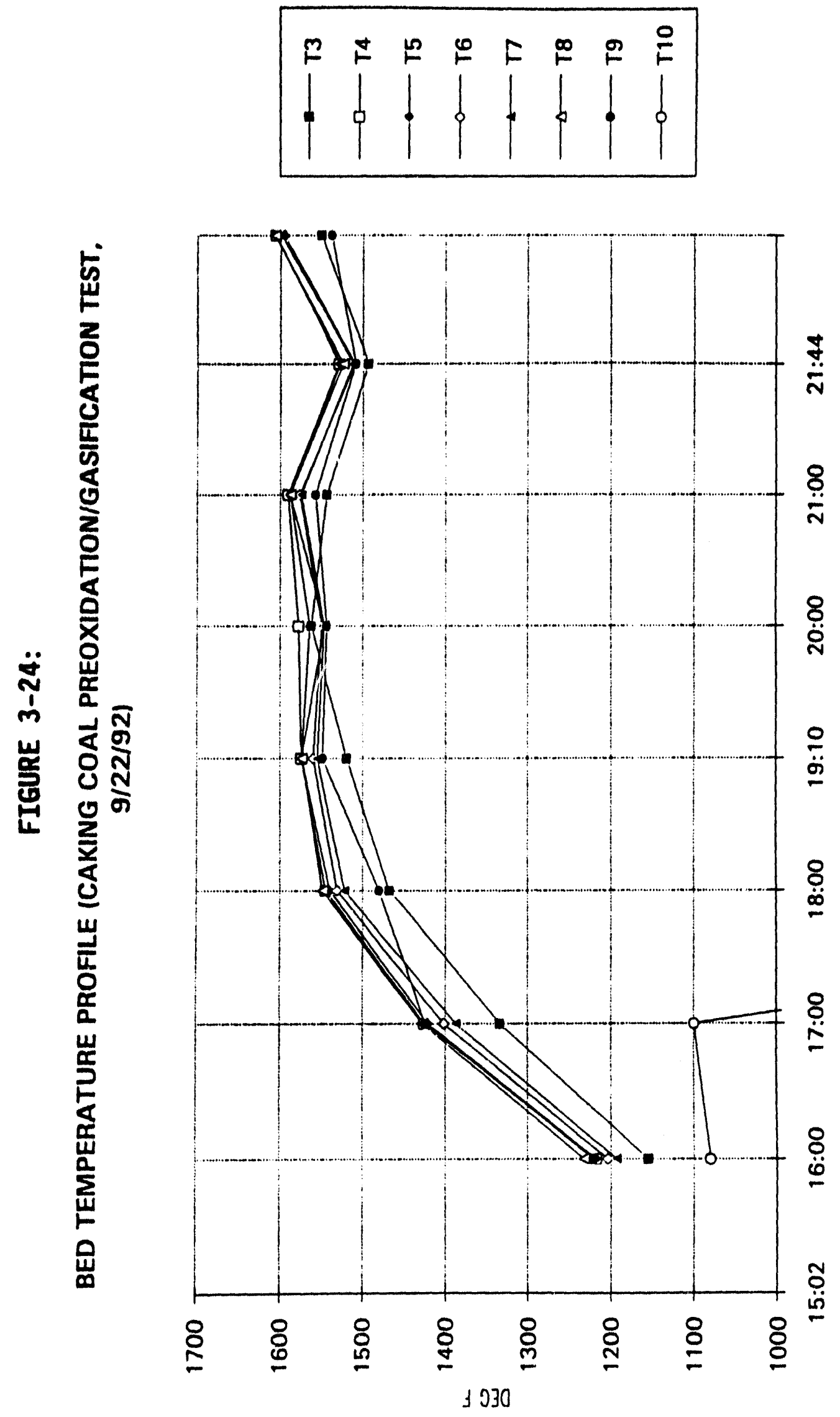


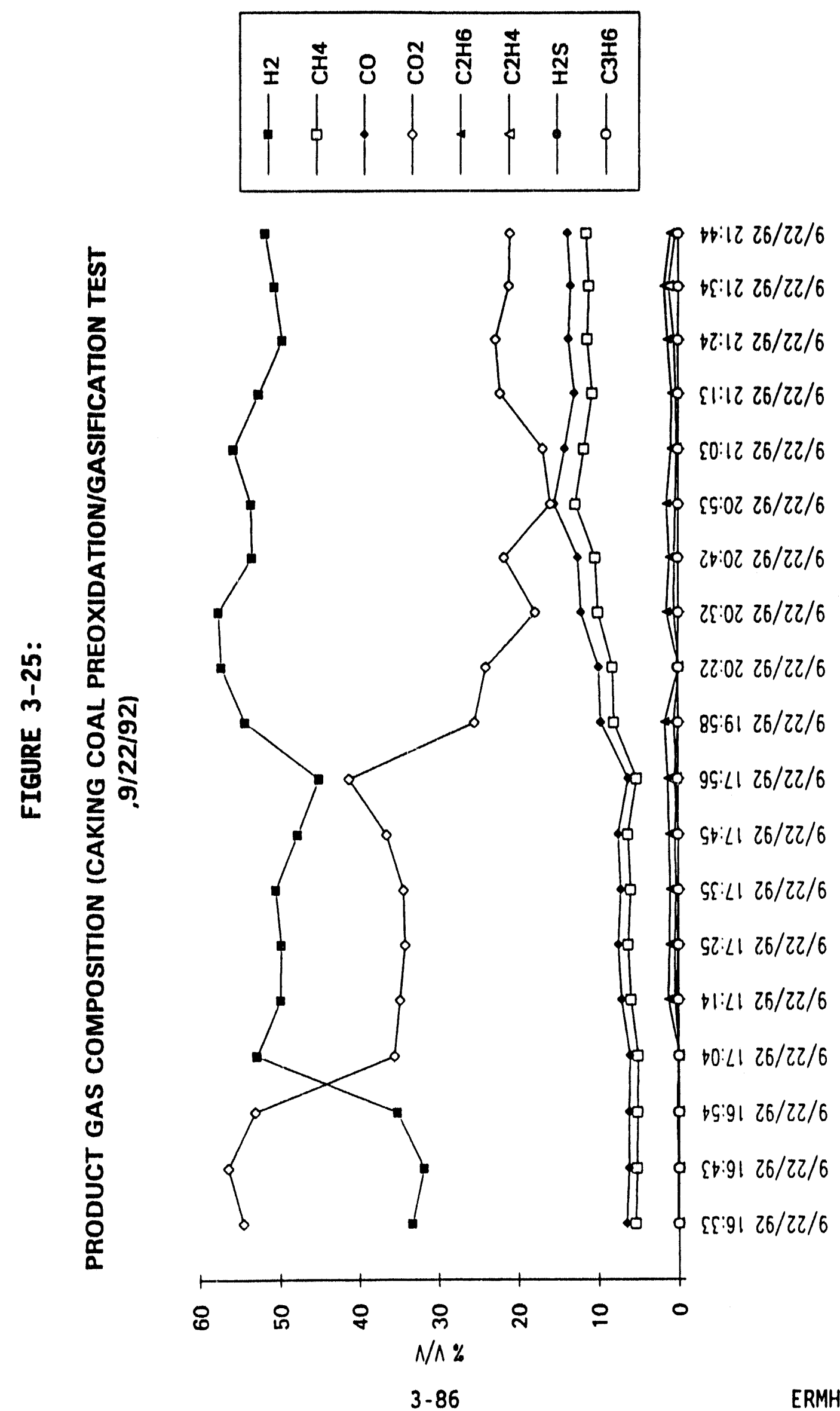


TABLE 3-53:

Average Propuct gas COMposition. IEST \#2

\begin{tabular}{||l|c|}
\hline HYDROGEN & T VIN \\
\hline METHANE & 52.20 \\
\hline CARBON MONOXIDE & 8.80 \\
\hline CARBON DIOXIDE & 10.61 \\
\hline ETHANE & 26.71 \\
\hline ETHYLENE & 1.14 \\
\hline HYDROGEN SULFIDE & 0.44 \\
\hline PROPYLENE & 0.10 \\
\hline TOTAL & 0.002 \\
\hline
\end{tabular}




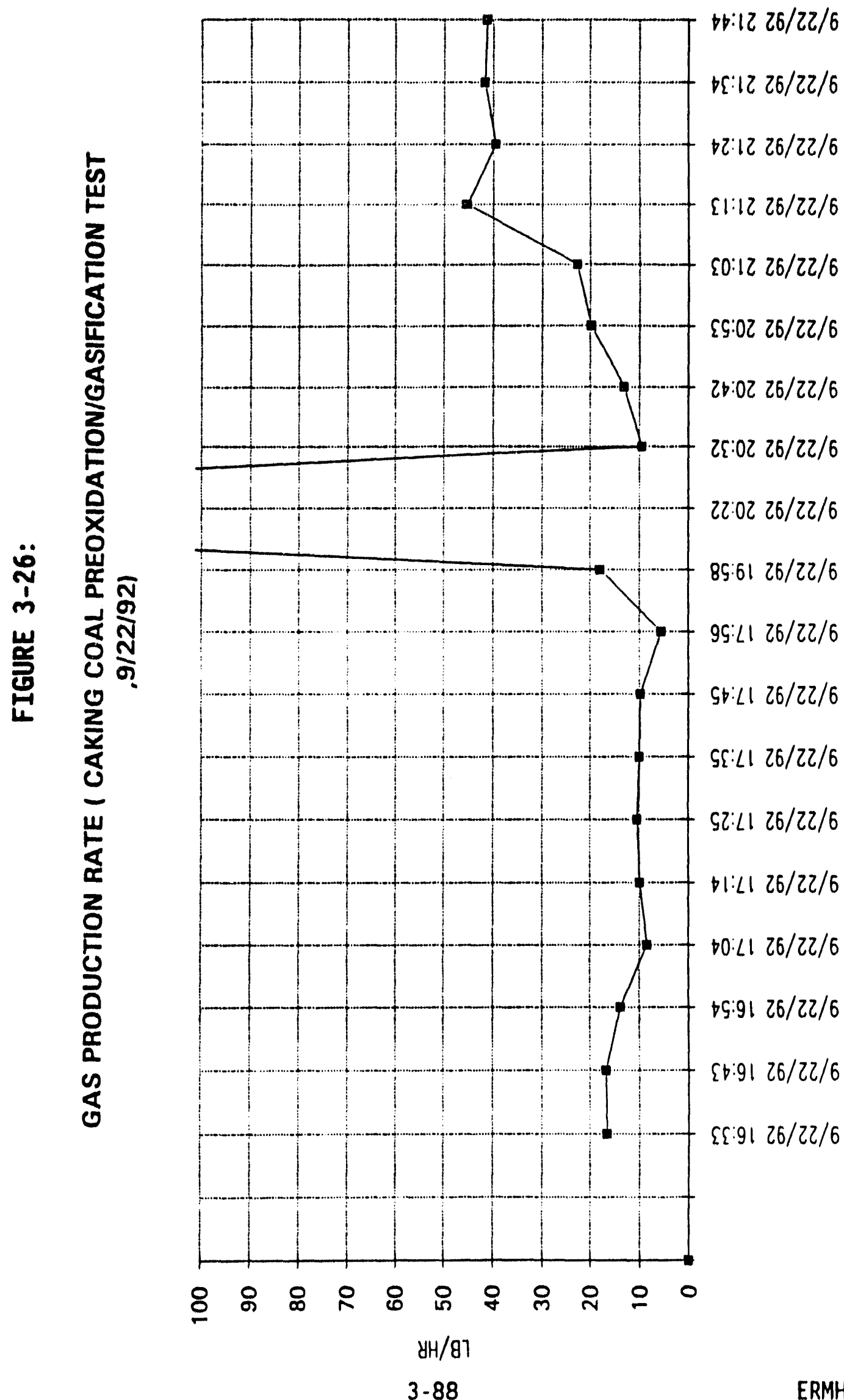




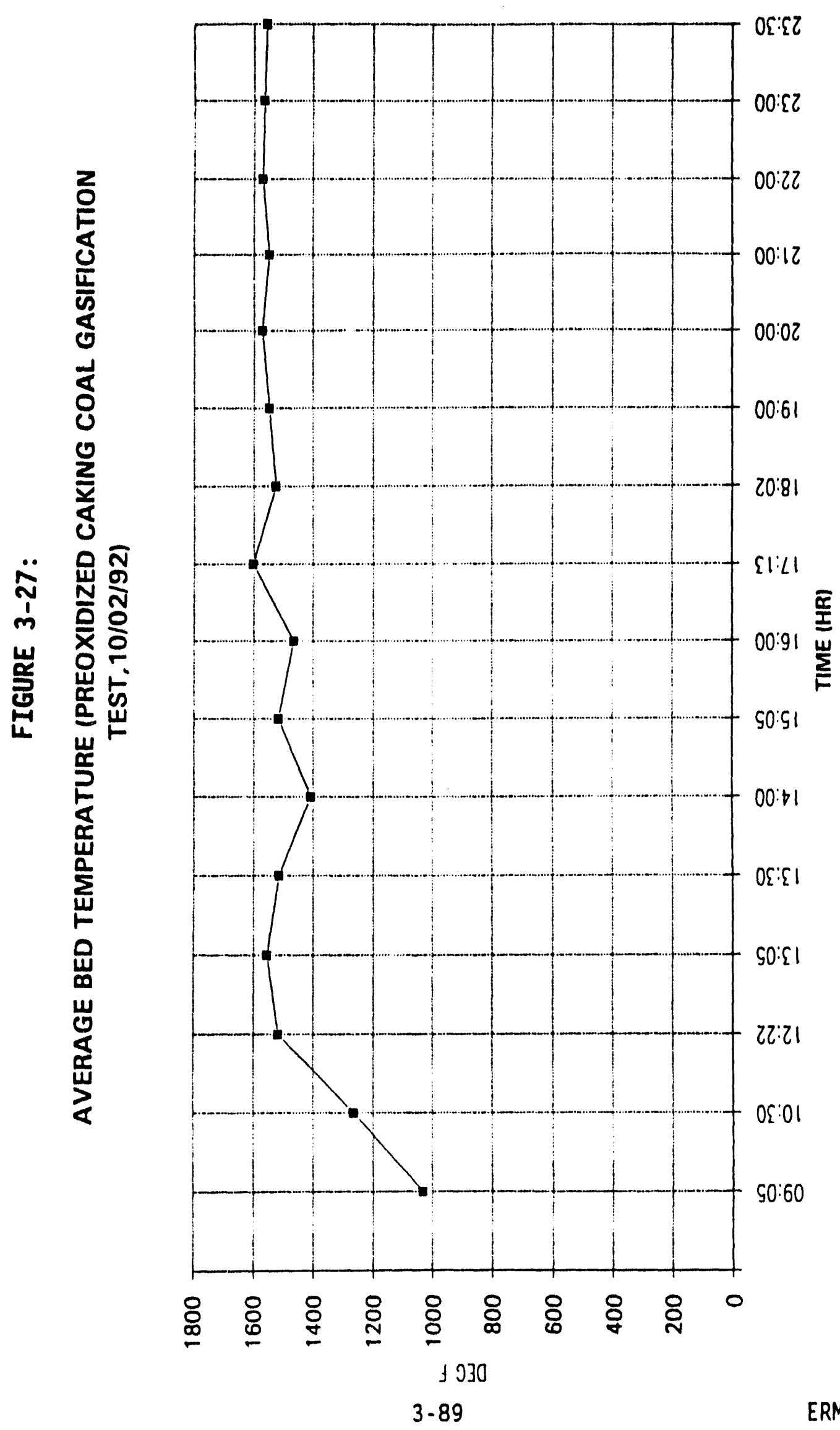

ERMH - 39F . 3B 
Eigure 3-28 shows the bed temperature history. Thermocouples $T_{3}$ to $T_{8}$ are reaching bed temperatures and as shown, bed temperature along the reactor is very uniform, indicating excellent fluidization. Figure 3-29 shows the product gas composition for this test.

Iable 3-54 gives mass balance summary for this test with a closure of 94.7 percent. During the calcination process, the $\mathrm{CO}_{2}$ concentration drops as the process reaches completion. Iable 3-55 shows the average product gas composition for this test.

\section{CARBON BALANCE AND GASIFICATION EFFICIENCY}

Based on the elemental analyses of the various input and output streams, elemental carbon balances were done for the tests and are tabulated in Iables 356 through 3-58. The tables also list the normalized carbon and material balances. The solids are directly measured and collected, whereas the gas production is calculated indirectly. The error in closure is attributed to the gas production amount and hence this quantity is normalized to obtain a carbon balance. Based on the new quantities, the material balance is carried out once again and are listed in the tables.

As can be seen from the above-mentioned tables, the carbon gasification efficiency is quite low for Tests \#1 and \#3. The low values are mainly attributed to the fact that the feed coal contained a large amount of fines which elutriated to the cyclone and collected as fines. As can be seen from the tables, the carbon content of the fines are as large as that in the product gas in Test \#1 and exceeds that of the product gas in Test \#3. It should be noted that the cyclone catch is not recycled to the gasifier in these laboratory-scale experiments. Cyclone solids recycle would increase the residence time and improve gasification efficiency. This effect can be seen in Test \#2 when the cyclone solids from the previous test were fed to the gasifier resulting in a much improved gasification efficiency of 82 percent as compared to 40 percent in Test \#1 and 44 percent in Test \#3. In a commercial application, cyclone solids recycle is an important aspect of gasifier design and must be included for best performance. 

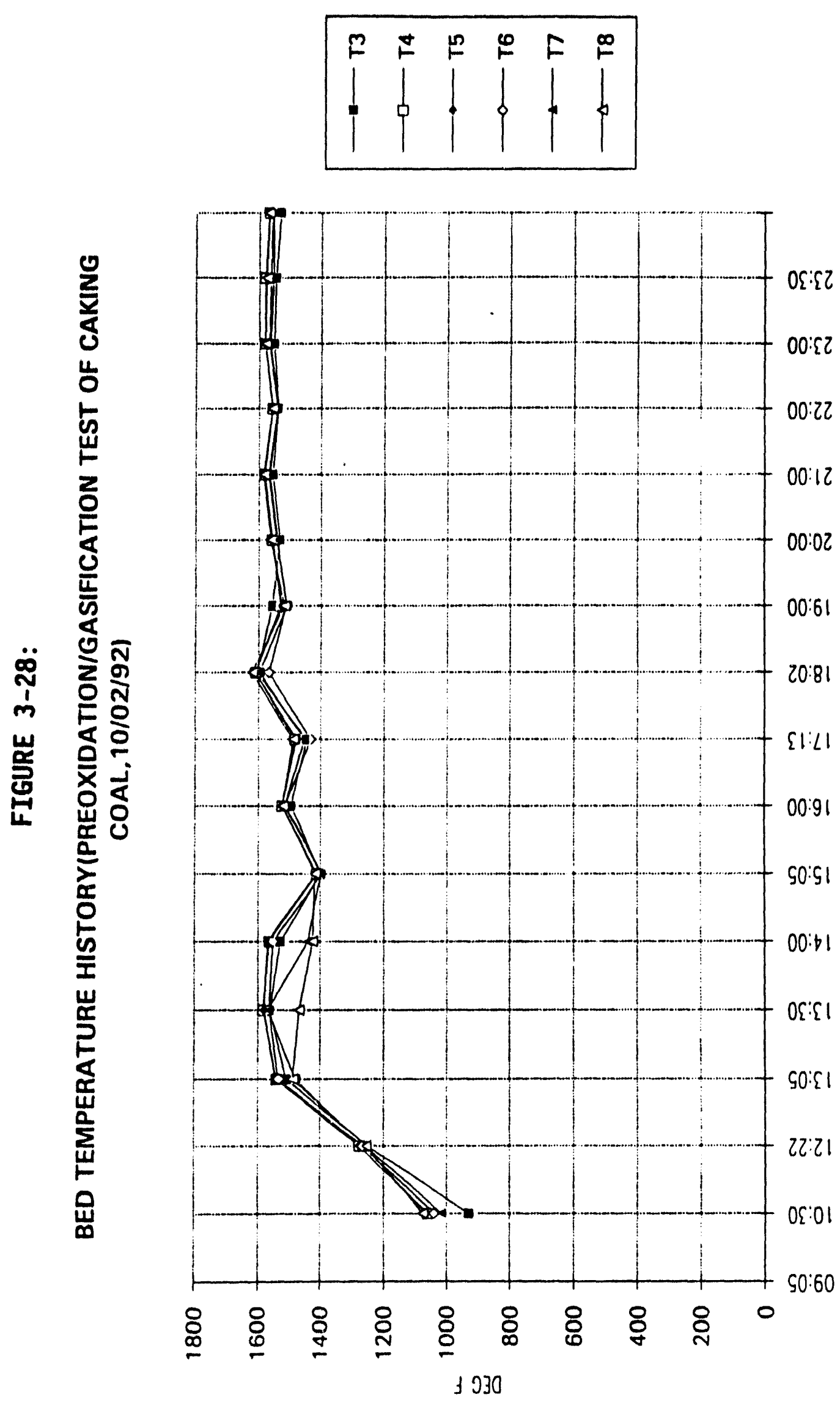

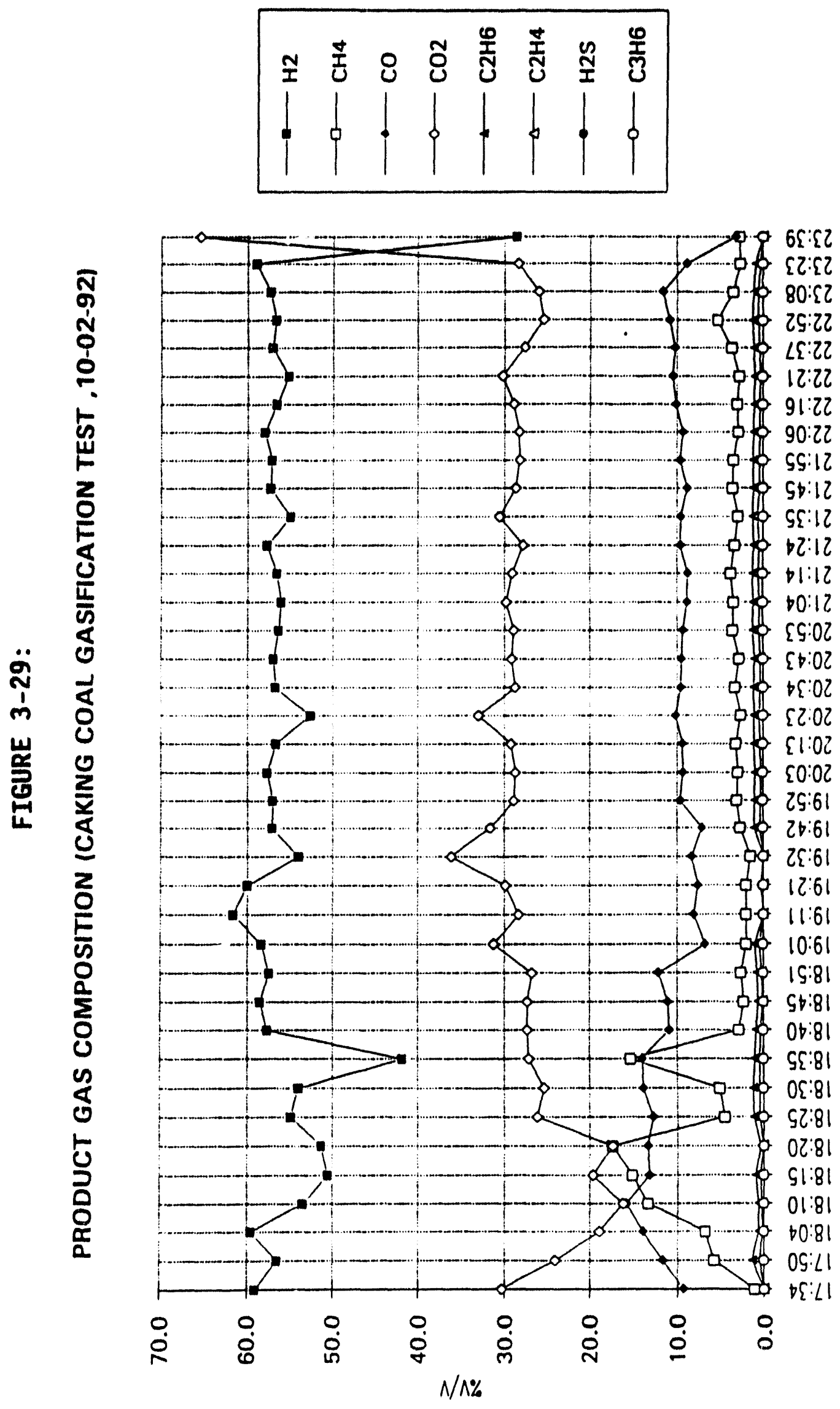
TABLE 3-54:

MASS BALANCE SUMMARY FOR TEST 13

(AVERAGE TEMPERATURE $1560^{\circ} \mathrm{F}$ )

\begin{tabular}{|l|c|}
\hline \multicolumn{1}{|c|}{ INPUT } & LBS \\
\hline FRESH LIMESTONE & 200.0 \\
\hline FEEDSTOCK & 186.2 \\
\hline COOLING WATER IN VENTURI SCRUBBER & 587.8 \\
\hline FLUIDIZATION STEAM & 324.0 \\
\hline TOTAL OUTPUT & 1298.0 \\
\hline & LBS \\
\hline FINAL BED & 83.8 \\
\hline CYCLONE CATCH & 174.4 \\
\hline VENTURI SCRUBBER CONDENSATE & 741.2 \\
\hline FILTER SOLIOS & 14.7 \\
\hline PRODUCT GAS & 142.5 \\
\hline CO ${ }_{2}$, DUE TO LIMESTONE CALCINATION & 88.0 \\
\hline TOTAL & 1244.6 \\
\hline CIOSUYE, \% & 95.9 \\
\hline
\end{tabular}


TABLE 3-55:

average Product gas Composition, Test \#3

\begin{tabular}{|c|c|}
\hline | COMPONENTS & . VI \\
\hline $\mathrm{H}_{2}$ & 55.50 \\
\hline $\mathrm{CH}_{4}$ & 4.48 \\
\hline $\mathrm{CO}$ & 10.16 \\
\hline $\mathrm{CO}_{2}$ & 28.55 \\
\hline $\mathrm{C}_{2} \mathrm{H}_{6}$ & 0.93 \\
\hline $\mathrm{C}_{2} \mathrm{H}_{4}$ & 0.37 \\
\hline $\mathrm{H}_{2} \mathrm{~S}$ & 0.017 \\
\hline $\mathrm{C}_{3} \mathrm{H}_{6}$ & 0.001 \\
\hline & 100.0 \\
\hline TOTAL & \\
\hline
\end{tabular}


TABLE 3-56:

CARBON AND MATERIAL BALANCE FOR TEST \#1 NORMALIZED FOR CARBON BALANCE

\begin{tabular}{|l|c|c|c||}
\hline \multicolumn{1}{|c|}{ INPUT } & C, LBS & $\begin{array}{c}\text { C, LBS } \\
\text { NORMALIZED }\end{array}$ & $\begin{array}{c}\text { MASS, LBS } \\
\text { NORMALIZED }\end{array}$ \\
\hline LIMESTONE & & & 169.0 \\
\hline PREOXIDIZED COAL & 89.06 & 89.06 & 196.6 \\
\hline LIMESTONE-COAL MIXTURE & & & 117.7 \\
\hline $\begin{array}{l}\text { COOLING WATER IN VENTURI } \\
\text { SCRUBBER }\end{array}$ & & & 331.0 \\
\hline FLUIDIZATION STEAM & & & 141.0 \\
\hline TOTAL & 89.06 & 89.06 & 837.6 \\
\hline \hline FINALUT BED & & & \\
\hline CYCLONE CATCH & 11.31 & 11.31 & 106.4 \\
\hline VENTURI SCRUBBER CONDENSATE & 8.61 & 8.61 & 489.0 \\
\hline FILTER SOLIDS & 2.27 & 2.27 & 17.80 \\
\hline PRODUCT GAS & 39.09 & 35.25 & 113.22 \\
\hline TOTAL & 92.90 & 89.06 & 838.62 \\
\hline ClOSUYC, \% & 104.31 & 100.00 & 100.1 \\
\hline Gasification Efficiency, \% & 43.89 & 39.58 & \\
\hline
\end{tabular}


TABLE 3-57:

CARBON AND MATERIAL BALANCE FOR TEST \#2 NORMALIZED FOR CARBON BALANCE

\begin{tabular}{|l|r|r|c||}
\hline \multicolumn{1}{|c|}{ INPUT } & C, LBS & $\begin{array}{c}\text { C, LBS } \\
\text { NORMALIZED }\end{array}$ & $\begin{array}{c}\text { MASS, LBS } \\
\text { NORMALIZED }\end{array}$ \\
\hline INITIAL BED MATERIAL & 10.45 & 10.45 & 109.0 \\
\hline CYCLONE BED MAKE-UP & 8.57 & 8.57 & 29.2 \\
\hline $\begin{array}{l}\text { FEEDSTOCK: P.0. COAL- } \\
\text { CYCLONE CATCH MIXTURE }\end{array}$ & 111.64 & 111.64 & 199.8 \\
\hline $\begin{array}{l}\text { COOLING WATER IN VENTURI } \\
\text { SCRUBBER }\end{array}$ & & & 417.5 \\
\hline FLUIDIZATION STEAM & & & 282.0 \\
\hline TOTAL & 130.7 & 130.7 & 1037.5 \\
\hline \hline FINAL BED & & & \\
\hline CYCLONE CATCH & 10.89 & 10.89 & 67.4 \\
\hline VENTURI SCRUBBER CONDENSATE & 1.18 & 1.18 & 589.1 \\
\hline FILTER SOLIDS & 6.63 & 6.63 & 23.8 \\
\hline PRODUCT GAS & 49.17 & 70.82 & 177.8 \\
\hline TOTAL & 109.0 & 130.7 & 1025.9 \\
\hline ClOSURe, \% & 83.43 & 100.00 & 98.89 \\
\hline Gasification Efficiency, \% & 57.02 & 82.13 & \\
\hline
\end{tabular}


TABLE 3-58:

CARBON AND MATERIAL BALANCE FOR TEST \#3 NORMALIZED FOR CARBON BALANCE

\begin{tabular}{|l|c|c|c|}
\hline \multicolumn{1}{|c|}{ INPUT } & C, LBS & $\begin{array}{c}\text { C, LBS } \\
\text { NORMALIZED }\end{array}$ & $\begin{array}{c}\text { MASS, LBS } \\
\text { NORMALIZED }\end{array}$ \\
\hline $\begin{array}{l}\text { INITIAL BED, FRESH } \\
\text { LIMESTONE }\end{array}$ & & & 200.0 \\
\hline FEEDSTOCK: PREOXIDIZED COAL & 141.83 & 141.83 & 186.2 \\
\hline $\begin{array}{l}\text { COOLING WATER IN VENTURI } \\
\text { SCRUBBER }\end{array}$ & & & 587.84 \\
\hline FLUIDIZATION STEAM & & & 324.0 \\
\hline TOTAL & 141.83 & 141.83 & 1298.04 \\
\hline & & & \\
\hline FINAL BED & 3.06 & 3.06 & 83.8 \\
\hline CYCLONE CATCH & 70.59 & 70.59 & 174.4 \\
\hline VENTURI SCRUBBER CONDENSATE & 2.302 & 2.30 & 741.2 \\
\hline FILTER SOLIDS & 3.12 & 3.12 & 14.7 \\
\hline PRODUCT GAS & 42.81 & 62.76 & 179.53 \\
\hline CALCINATION EVOLVED CO 2 & & & 88.0 \\
\hline TOTAL & 121.87 & 141.83 & 1281.63 \\
\hline ClOSUR, \% & 85.93 & 100.00 & 98.74 \\
\hline GasifiCation EffiCienCy, \% & 30.18 & 44.25 & \\
\hline
\end{tabular}




\section{SECTION 4.0}

\section{IECHNICAL AND ECONOMIC EVALUATION}

In the following section, a process evaluation of MTCI's hydrogen production from direct liquefaction residues, char and coal is made based on the preliminary database acquired in the feasibility tests. The process evaluation focuses primarily on the gasifier train and includes consideration of design trade-offs and their impact on economics and performance of the plant.

The process evaluation is segregated into specific subtopics relating to system specifications, operation, and performance which may directly impact the overall economics of hydrogen production. These subtopics include a discussion of feedstock quality and preparation, process consumables, operating conditions and reactivity, product gas quality, hydrogen yield, $\mathrm{CO}_{2}$ removal requirements, and environmental issues. In each case, an effort is made to draw meaningful comparisons between the MTCI process and alternative technologies.

\subsection{CAPITAL AND OPERATING COST CONSIDERATIONS}

Capital component costs for the gasification facility may include feedstock handling and preparation, gasifier and heat recovery, gas conditioning, acid gas removal, sulfur recovery and tail gas treatment, and general facilities. In the case of partial oxidation units, additional capital costs for oxidant feed $\left(\mathrm{O}_{2}\right.$ plant) systems are also required.

Operating costs for the facility include electricity, water, catalyst and chemicals, operating labor, maintenance, and administration. While it is beyond the scope of this assessment to consider each of these cost factors in detail, an effort will be made to highlight the most significant differences between capital and operating costs for the indirect gasification plant and the partial oxidation gasification plant. These differences are primarily related to oxygen production as required in partial oxidation gasification plants. 
Meaningful cost data for partial oxidation coal gasification plants can be derived from assessments conducted for the coolwater coal gasification facility which incorporated a Texaco oxygen-blown coal gasifier. In a report prepared by Fluor Engineers, ${ }^{(15)}$ capital and operating cost data are provided for the integrated gasification-combined cycle (IGCC) plant in 1984 dollars.

The base cost estimate provided in the reference report, known as the "Unphased GCC Plant, " was utflized to provide an estimate of the overall capital and operating costs of a Texaco oxygen-blown gasifier and its peripherals and to determine the proportion of these costs attributed to the oxygen production system. Sufficient detail is provided for most of the cost data to deduct the cost of the power train so as to separately identify the cost of the gasification system and its peripherals, including the oxygen plant. Where insufficient detail is provided, simplifying assumptions were made, which are noted. The term "unphased" is used to designate a plant that would be built in its entirety in one phase and operated upon completion of the entire plant, as opposed to the construction of a plant in several phases, with commercial operations beginning upon completion of each phase.

A summary of the system performance basis for the cost estimate is provided in Table 4-1.

\section{TABLE 4-1:}

\section{Summary of SYSTEM PERformance Cost Estimate Basis}

1. Design Basis: Texaco Gasifier/Illinois No. 6 Coal, 95\% Sulfur Removal

2. Gasification Per-Pass Carbon Conversion, $\%$

3. Coal Feed Rate, T/D

4. Feed Coal Heat Input, MMBtu/hr

5. Oxygen $\left(100 \% \mathrm{O}_{2}\right) /$ Coal Ratio, $1 \mathrm{~b} / \mathrm{Ib}$

6. Slurry Concentration, wt.\%

7. Gasification Section Average Pressure, psig

8. Crude Gas HHV (dry), Btu/scf

9. Oxygen Plant Product Quality, $\% \mathrm{O}_{2}$

10. Oxygen Plant Power Requirements, net MW

11. Capacity Factor for Variable 0\&M Costs, \%

47.22

12. Net Power Output, GCC System, MW 
Estimates of the overall capital cost and individual capital cost for components of the GCC system ${ }^{(15)}$ are provided in Table 4-2. This table provides the cost proportion of each plant system as a percentage of the total capital cost both with and without inclusion of the power generation related systems. For the system labeled "general facilities," no deduction was made for the portion of the facilities that would support the power-generation systems.

Inspection of Table 4-2 indicates that the oxidant feed section of the 3260 ton/day coal gasification plant is estimated to cost about $\$ 84$ million in January 1991 dollars. This is equivalent to about 15 percent of the overall capital cost of a GCC plant, and about 21 percent of a facility that only consists of a gasification $\mathrm{plant}$ and its peripherals.

Fixed operating and maintenance costs for the gasification plant exclusive of the power generation components was est imated to be $\$ 15,230,000$ per year (1991 dollars). Assuming that fixed costs for the oxygen plant can be prorated based proportionately on component capital costs $(21.1 \%)$ to total plant costs, the fixed 0\&M costs for the oxygen plant are $\$ 3,214,000$ per year (1991 dollars). Additional operating costs for oxygen plant electricity consumption using latest Southern California Edison figures for capacity demand and energy charge are calculated to be $\$ 13,230,000$ per year. Thus, the operating costs for the oxygen plant account for over 50 percent of the total operating cost for the gasification facility exclusive of feedstock charges.

If a capital carrying charge of 15 percent is assumed, the annual capital charge for the oxygen plant is $\$ 12,570,000$. Thus, the combined capital plus 0\&M costs attributed to the oxygen $\mathrm{plant}(\$ 29,014,000 / \mathrm{yr})$ account for 33 percent of the total plant capital plus 08M costs $(88,113,000 / \mathrm{yr})$ exclusive of feedstock charges. Note that the oxygen production cost translates to approximately \$26/ton of oxygen which appears to be conservative.

In a separate study concerning the production of chemical feedstocks using the Shell partial oxidation gasification process, oxygen plant operating costs were estimated to account for over 45 percent of the total production costs for a $100 \times 10^{6}$ SCFD $\mathrm{H}_{2}+\mathrm{CO}$ plant, ${ }^{(16)}$ exclusive of feedstock charges. 
TABLE 4-2:

\section{CAPITAL COST ESTIMATE, UNPHASED GCC PLANT \\ $(3,260 T / D)$ \\ (Thousands of January, 1991 Dollars")}

\section{PLANI SECTION}

1. COAL RECEIVING, GRINDING, AND SLURRY PREPARATION

2. OXIDANT FEED $\left(2.962\right.$ TPD, $\left.95 \% \mathrm{O}_{2}\right)$

3. GASIFICATION, HIGH-TEMP. GAS COOLING, PARTICULATE REMOVAL, AND ASH REMOVAL.

4. LOW-TEMP. GAS COOLING AND FUEL GAS SATURATION

5. ACID GAS REMOVAL

6. SULFUR RECOVERY

7. TAIL GAS TREATING

8. STEAM, CONDENSATE, AND BOILER FEEDWATER

9. COMBINED-CYCLE POWER GENERATION

10. GENERAL FACILITIES

11. INITIAL CATALYSTS AND CHEMICALS

OVERALL TOTAL

TOTAL, EXCLUDING POWER GENERATION (Items 8 and 9)
EXCLUDING ITEMS 8 AND 9 (POWER GENERAT.)

COST

(\$1000)

PERCENT

OF TOTAL

PERCENT OF TOTAL

39,600

7.0

9.9

83,800

14.9

21.1

94,700

16.8

23.8

29,600

5.3

7.4

17,700

3.1

4.5

12,100

2.2

3.0

5,900

1.0

1.5

6,400

1.1

$N / A$

159,500

28.3

N/A

114,300

20.1

28.5

1,200

0.2

0.3

564,800

398,900

* January 1991 dollars were calculated from reported January 1984 dollars using a factor of 1.41 representing 7 years at $5 \%$ inflation each year. 
Based on this work, it is evident that oxygen costs have an enormous impact on the total hydrogen production costs in a partial oxidation gasiffer system. Therefore, the indirect gasification process, which does not require consumption of oxygen, has an immediate potential to reduce hydrogen production costs by over 30 percent.

An independent study by AMOCO using the MTCI data and comparing the MTCI system with the Texaco gasifier arrived at a different conclusion, i.e., that a low-cost, high-pressure gasifier would be necessary to compete successfully with the Texaco system primarily by eliminating the expensive crude gas compression requirement. The AMOCO analys is is provided in Appendix $A$. On the other hand, a study on the production of hydrogen from biomass and coal completed in $1993^{(17)}$ also using ASPEN seems to be in agreement with the MTCI and Reed ${ }^{(16)}$ studies.

\subsection{TECHNICAL ANALYSIS OF PROCESS}

A brief description of the principal flow streams in the MTCI gasification process is given here. This process description is not intended to provide a complete 1 llustration of all necessary features of the plant as integrated with the direct liquefaction facility, but rather to convey a basic understanding of plant flows and operation.

Referring to Eiqure 4-1, liquefaction residues or coal are metered through a lock hopper and injection screw feed system to the fluid-bed gasifier R-1. Superheated steam, introduced into the base of $R-1$, reacts with the char to produce a hydrogen-rich process gas. The process gas enters a coarse solids recirculation cyclone $V-1$, and a fines cyclone $V-2$ where the bulk of the entrained particulates are removed. Residual char and ash are discharged through a lock hopper. The process gas is cooled in the process gas boiler E-3 where saturated steam is generated to partially satisfy the gasifier steam demand. The process gas is then treated in a venturi scrubber $V-3$ and reheated in $E-4$ as needed for further gas processing, such as in a shift reactor. Scrubber circulation water is clarified in V-5 to concentrate suspended solids which are discharged from the system as sludge dregs. 


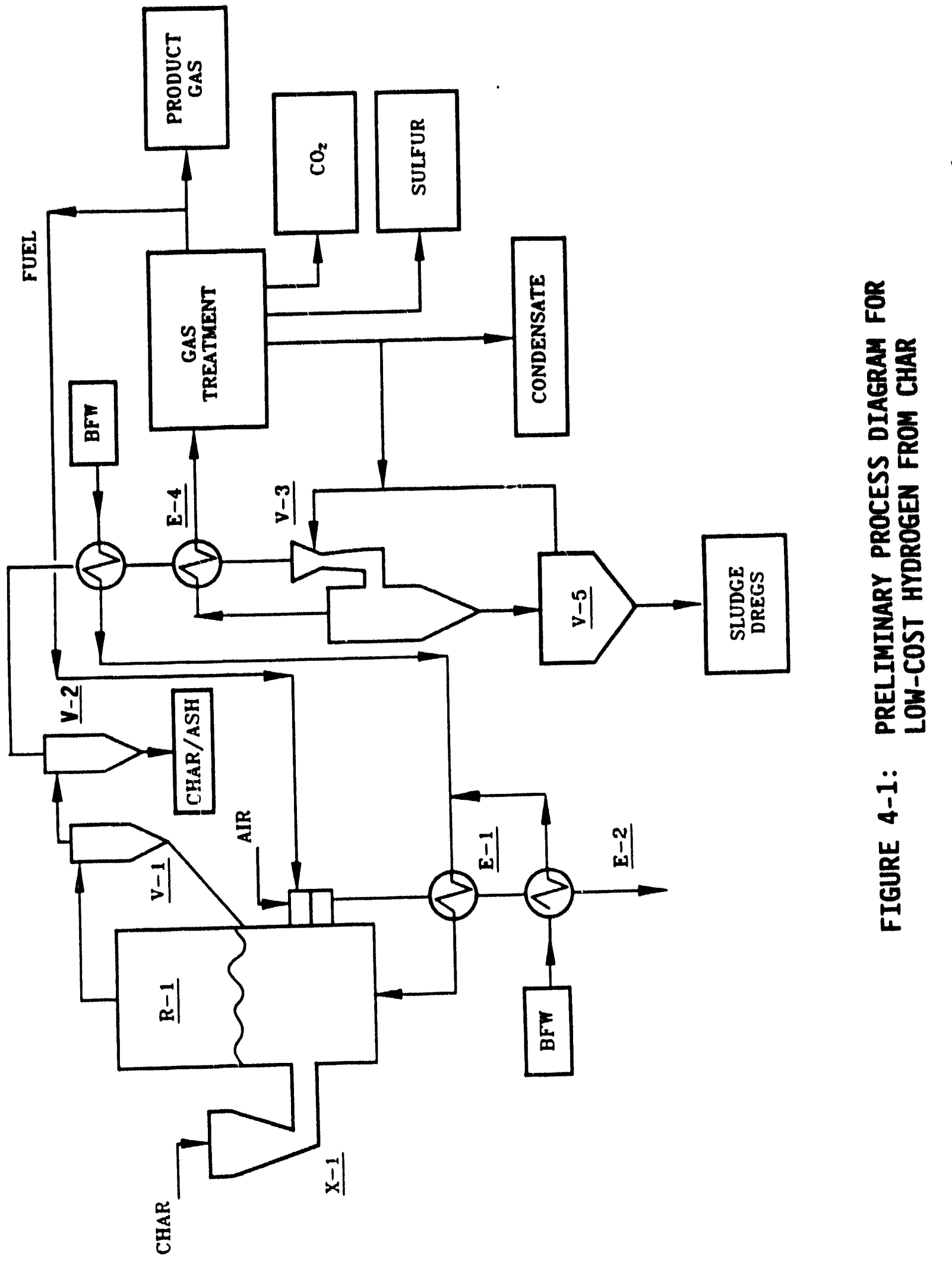


The constituents of a gas treatment unit may vary according to the hydrogen gas quality requirements. Bastcally, it includes three primary operations. The hydrogen sulfide is to be removed by liquid phase redox sulfur recovery process and element sulfur is obtained as a by-product. The acid gas is to be removed by washing with alkaline solution, carbon dioxide can be recovered as another byproduct. Any remaining carbon monoxide is to be converted to hydrogen and carbon dioxide by catalytic shift reaction. The carbon dioxide formed in the shift reaction is to be removed again. These processes will not be discussed in detail since they are existing technologies and are not directly related to the MTCI gasification technology. However, membrane technologies now in the development stage may present an effective low-cost option for the purification of hydrogen from syngas derived from coal or biomass.

An important high-temperature system of silica glass membranes suitable for hydrogen separation from syngas has been developed by the California Institute of Technology, Pasadena, California. This technology utilizes a Vycor tube with a thin layer of $\mathrm{SiO}_{2}$ deposited on $\mathrm{it}$. The resultant membrane is permselect to hydrogen only. Hydrogen in syngas will diffuse through the membrane leaving the impurities behind. This separation technology does not suffer from the drawbacks exhibited by the others. Hydrogen can be effectively removed by selective permeation of hydrogen through specially prepared membranes. The membrane technology is based on the molecular permeation technique which is dependent completely on the molecular size of the gases. The molecular size of hydrogen is the smallest and very different from the other components in the syngas. Therefore, highly selective removal of hydrogen can be very effective by this method. Moreover, this membrane operates at high temperature and hence is energy-efficient for hydrogen separation from coal gasification syngas. This concept is particularly suitable for purification of the product gas from the MTCI steam reformer. MTCI was awarded an SBIR Phase I project to demonstrate the feasibility of manufacturing hydrogen purification modules using this concept. (13)

A portion of the treated process gas is withdrawn for use as combustion fuel in the pulsating heat exchanger $\mathrm{H}-1$. Alternatively, the fuel source might include feedstock char, purge gases from the liquefaction loop, or a combination thereof. A combustion air blower supplies combustion air to the pulsating 
burner, and flue gases exit the immersed heat exchanger system after releasing the needed gasification heat load. Sensible heat in the flue gases exiting $\mathrm{H}-\mathrm{l}$ is recovered in flue gas boller E-2. Steam from E-2 and E-3, which is sufficient in quantity to satisfy the gasifier's internal steam demand, is superheated in E-1 prior to the injection to the gasifier bed. Flue gases are then vented to the stack without any further treatment.

\subsubsection{GastFTGATION RATE}

For a given reactor the rate of production is directly proportional to the reaction rate. Many factors affect the rate of reaction. These factors include temperature, pressure, reactivity of feedstock, concentration of reactants, and the existence of a catalyst. A simple expression of the reaction rate is

$$
W=k_{r}(T) C_{B} P_{W}
$$

where $W$ is the carbon gasification reaction rate, defined as the mass of converted carbon in unit time and unit volume of reactor, $k_{r}(T)$ is the temperature dependent rate constant, $C_{B}$ is the reactor bed carbon concentration, and $P_{W}$ the partial pressure of water vapor.

The temperature dependence of rate constant $k_{r}$ can be expressed by Arrhenius' equation:

$$
k_{r}=k_{0} \operatorname{EXP}(-E a / R T)
$$

where $k_{0}$ is a temperature independent constant reflecting the reactivity of reactant (in our case, the reactivity of different forms of feed carbon), Ea is the activation energy, $R$ is the gas constant and $T$ is the absolute temperature of the reactor. The partial pressure of water vapor can be expressed by the production of total pressure of the reactor and the molar fraction of water in the gas phase $X_{w}$.

$$
P_{w}=P X_{w}
$$


This brief analysis provides a clear picture of the factors affecting the production of gas from different carbon-containing feedstocks. The rate of production would be linearly proportional to the bed carbon concentration $C_{B}$, to the pressure of gasifier $P$, to the steam molar fraction in the gas phase, and to the rate constant $k_{o}$ which represents the reactivity of the feed carbon. The reactor temperature affects the production rate exponentially so that increasing the reactor temperature would increase the reaction rate significantly. Existence of an accelerating catalyst would reduce the activation energy and, thus, increase the reaction rate.

A typical, intermediate reactivity value is $0.1 \mathrm{~min}^{-1}$ at $1 \mathrm{~atm} P_{W}$ and $900^{\circ} \mathrm{C}$. Reported activation energies are around $35,000 \mathrm{calorie} / \mathrm{mol}$. These data lead to a rate constant coefficient of $k_{0}=2.0 \times 10^{7} \mathrm{hr}^{-1} \mathrm{~atm}^{-1}$. Using a typical value of $X_{w}=0.3$ and bed carbon concentration of $25 \mathrm{lb} / \mathrm{ft}^{3}$, the gasification reaction rate is calculated as a function of temperature for three different system pressures as shown in Iable 4-3.

TABLE 4-3:

Predicted Specific Throughput (LB/hr/FT³)

VS. TEMPERATURE AND PRESSURE

\begin{tabular}{|c|c|c|c|c|c|}
\hline \multicolumn{2}{|c|}{ TEMPERATURE } & \multicolumn{4}{|c|}{ PRESSURE } \\
\hline$\left({ }^{\circ} \mathrm{C}\right)$ & $(\cdot F)$ & $1 \mathrm{~atm}$ & $3 \mathrm{~atm}$ & $10 \mathrm{~atm}$ & $15 \mathrm{~atm}$ \\
\hline 700 & 1292 & 2.1 & 6.2 & 20.6 & 30.9 \\
\hline 750 & 1382 & 5.0 & 15.0 & 49.9 & 75.0 \\
\hline 800 & 1472 & 11.1 & 33.3 & 111 & 75.0 \\
\hline 850 & $156 ?$ & 23.1 & 69.3 & 231 & 166.5 \\
\hline 900 & 1652 & 45.0 & 135.0 & 450 & 675.0 \\
\hline 950 & 1742 & 83.4 & 250.0 & 830 & 1245.0 \\
\hline
\end{tabular}


The purpose of this analysis is to find all means that can increase the production rate for a given reactor and achieve the maximum thermal efficiency and production economies. The methods of increasing the production rate include the increase of reaction pressure, increase of steam/carbon ratio, increase of bed carbon concentration, selecting a highly reactive feedstock, increase of reactor temperature, and use of catalysts. Not all the mentioned methods can be used without limitation. The next subsection will discuss the limit of the production rate in the indirect steam gasification reactor.

\subsubsection{LIMITS OF GASTEIER PRODUCTTON RATE}

There are several factors that may restrict the use of the above-mentioned methods for raising the production rate in a given design of a gasifier. The limitations of these variables is discussed in this section to explore conditions of maximum productivity and economy.

\subsubsection{Operation Pressure}

The influence of pressure on reaction rate is positive. Increasing pressure a) so offers significant advantages in reducing equipment size and, potentially, capital cost. In addition, since the purified hydrogen product must be delivered at high pressure, the ability to operate under pressure assists in reducing the required number of compression stages as well as the energy of compression.

In a study sponsored by DOE/METC, K\&M Engineering and Consulting Corporation $^{(18)}$ examined the feasibility of a pressurized pulse combustion heating system for coal gasification and concluded that it would be technically feasible and economically beneficial. They concluded that the MTCI pulse gasifier can be pressurized on the pulse combustor side and the gasifier side simultaneously so that the pulse combustor flue gas can be expanded in gas turbines generating power and effectively reduce the material stress problems that would be inherent in pressurizing the reactor vessel only.

An analysis to determine the effect of pressure on the pulse combustor tube heat transfer coefficient utilizing MTCI operating data from its atmospheric unit was conducted by Mountain Bay Associates, Inc. for MTCI and by K\&M Engineering 
and Consulting Corporation for the Morgantown Energy Technology Center. (18) Each considered the tube side heat transfer coefficient in greater detail.

The heat transfer coefficient can be expressed in terms of the Reynolds Number, Re, and Nusselt Number, Nu.

$$
\begin{aligned}
& \operatorname{Re}=\frac{D_{i} V_{\rho}}{\mu}=\frac{4 W}{\mu D_{i}}=\frac{4 Q_{i}}{\mu C_{p} T_{i} D} \\
& N u=\frac{h D_{j}}{k^{\wedge} R}
\end{aligned}
$$

where:

$$
\begin{aligned}
& D_{1}=\text { Inside tube diameter } \\
& V=\text { Gas flow velocity } \\
& \rho=\text { Gas density } \\
& \mu=\text { Gas viscosity } \\
& Q=\text { Volumetric gas flow rate } \\
& T_{1}=\text { Tube inlet temperature. }
\end{aligned}
$$

The Reynolds numbers for the MTCI tests were observed to be in the range $2300<\operatorname{Re}<2800$; in other words, in the transition range between laminar and turbulent flow. In such cases, the Nusselt number is also a function of the length-to-diameter ratio L/D, which in the test case is about 60 . For an $L / D$ of 60 , the literature predicts $\mathrm{Nu} / \mathrm{Re}$ values of about 0.0033 . Such values correspond to $h$ and, hence, $U$ values of about 1.5 whereas the tests conducted at MTCI yields an $h$ valued at about 8 to 15 , and 1 'about 6 to 11 . It can be concluded that an overall enhancement ratio between 5 and 8 was achieved by pulsed operation at atmospheric pressure operating condition.

The effect of pulse combustion is to increase the tube side heat transfer. This can be expressed by determining the effective Reynolds number which would provide the observed enhancement. In the case of the tests conducted by MTCI, the effective Reynolds numbers calculated by reference to "Theoretic" curves is 
18,700 which puts the effective flow patterns well beyond the transition region and into the fully developed zone.

This observation makes it possible to project effective Reynolds numbers and hence effective pulse tube heat transfer coefficients for higher pressure operation. The effective Reynolds number enhancement is about 9.35. That is:

$$
(\operatorname{Re})_{\text {eff }}=9.35 \mathrm{Re}
$$

For highly developed turbulent flow

$$
\mathrm{Nu}=0.004 \mathrm{Re}^{0.8}
$$

or

$$
(\mathrm{Nu})_{\text {eff }}=(0.004)(9.35)^{0.8} \mathrm{Re}^{0.8}
$$

The Reynolds number is approximately proportional to the pressure of the operation for all other parameters being constant. Thus, it is evident that pressurized combustion yields higher heat transfer coefficients and therefore higher heat transfer rates but will not result in higher levels of $\mathrm{NO}_{\mathrm{x}}$ production. Thus, this effect of pressure on steam reforming throughput and heat transfer coefficients is positive and does not affect the environmental performance of the system.

It was also originally estimated that the heat transfer rate from the indirect pulse heater tubes would be about $15,000 \mathrm{Btu} / \mathrm{hr} / \mathrm{ft}$ at atmospheric pressure. At that time there was no consideration of the effect of pressurization on heat transfer rates. However, MTCI and Solar Turbines ${ }^{(19)}$ have recently completed pulse combustion tests under an SBIR contract at pressures up to 7 atm (105 psia). It was found that the overall heat transfer coefficient is proportional to the square root of the pressure in the pulse combustor. Hence, it is possible to increase the heat flux from the indirect pulse heater by increasing the combustor pressure. Table 4-4 provides the data from these recently conducted tests by Solar Turbines in their pressurized facility at San Diego, California (No. DE-AC05-88ER80640). 


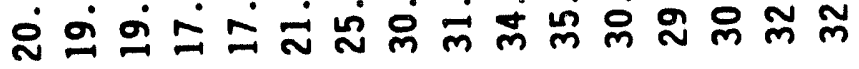

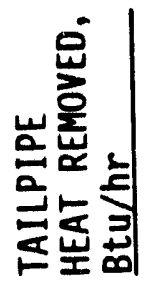

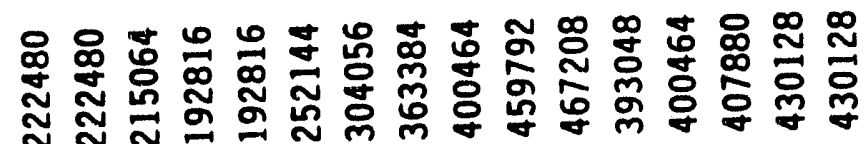

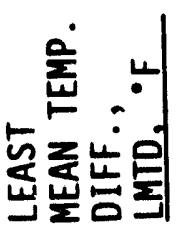

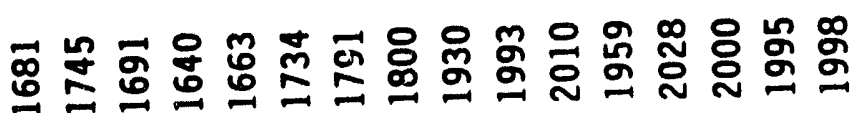

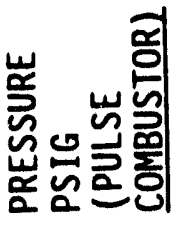
ஸ m

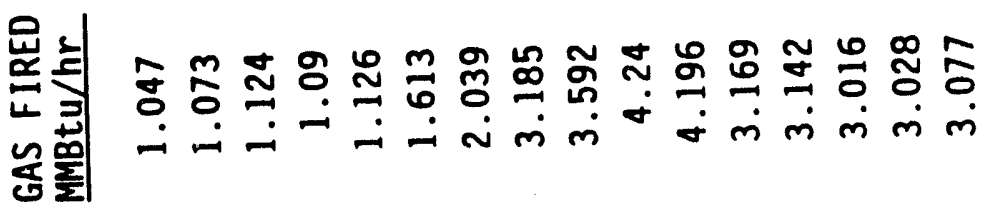

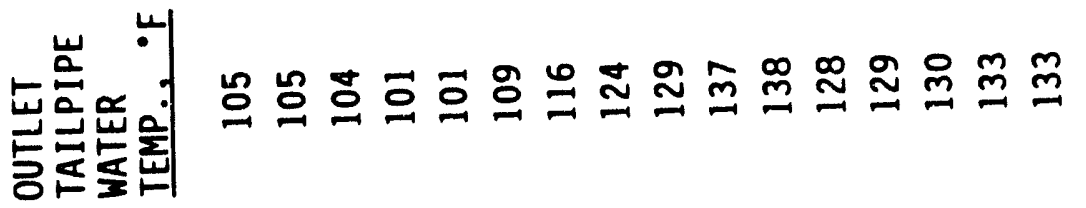

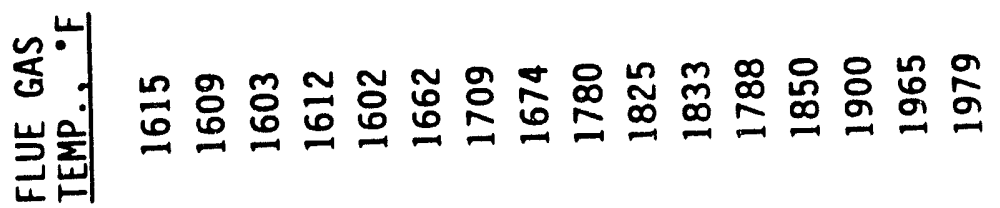

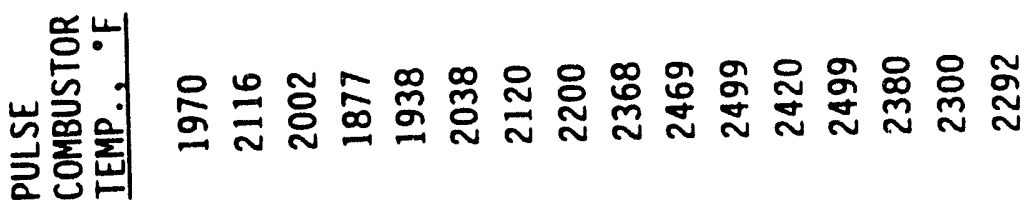
点家 


\subsubsection{Steam Ratio}

The gasifier production rate or throughput is directly influenced by the steam ratio. Increased steam ratio results in an increased throughput under the conditions that all other variables are maintained constant. For the MTCI gasification technology, the steam flow rate is adjusted to control the fluidization of reaction bed. Therefore, it must be constrained in a certain range to maintain proper fluidization of the reactor bed.

The reactor may be designed to adopt higher steam flow rate. However, increased steam consumption results in higher losses of steam latent heat. Besides, a reactor to accommodate higher steam flow rate will have a lower heightto-diameter ratio (L/D) which results in expensive vessel construction and present certain difficulties for integrating the heat exchange system uniformly through the bed cross-section.

\subsubsection{Bed Carbon Concentration}

The gasifier production rate is directly proportional to the bed carbon concentration under the condition where other variables are maintained constant. While increased bed carbon concentration leads to higher throughput, it results in higher loss of carbon in the de-ashing stream. The optimized bed carbon concentration may be found by performing a material balance.

A simplified overall material balance for the bed is illustrated in Figure 4-2. Based on this model, a mass balance for carbon and ash constituents yields:

CARBON

$$
X_{F} M_{F}=k M_{B} X_{B}+M_{E} X_{E}+M_{D} X_{D}
$$

ASH

$$
\left(1-x_{F}\right) M_{F}=\left(1-x_{E}\right) M_{E}+\left(1-X_{D}\right) M_{D}
$$

where $M_{F}, M_{E}$ and $M_{D}$ are the mass flow rates of the feed, elutriate, and bed drain material from the gasifier, respectively; 


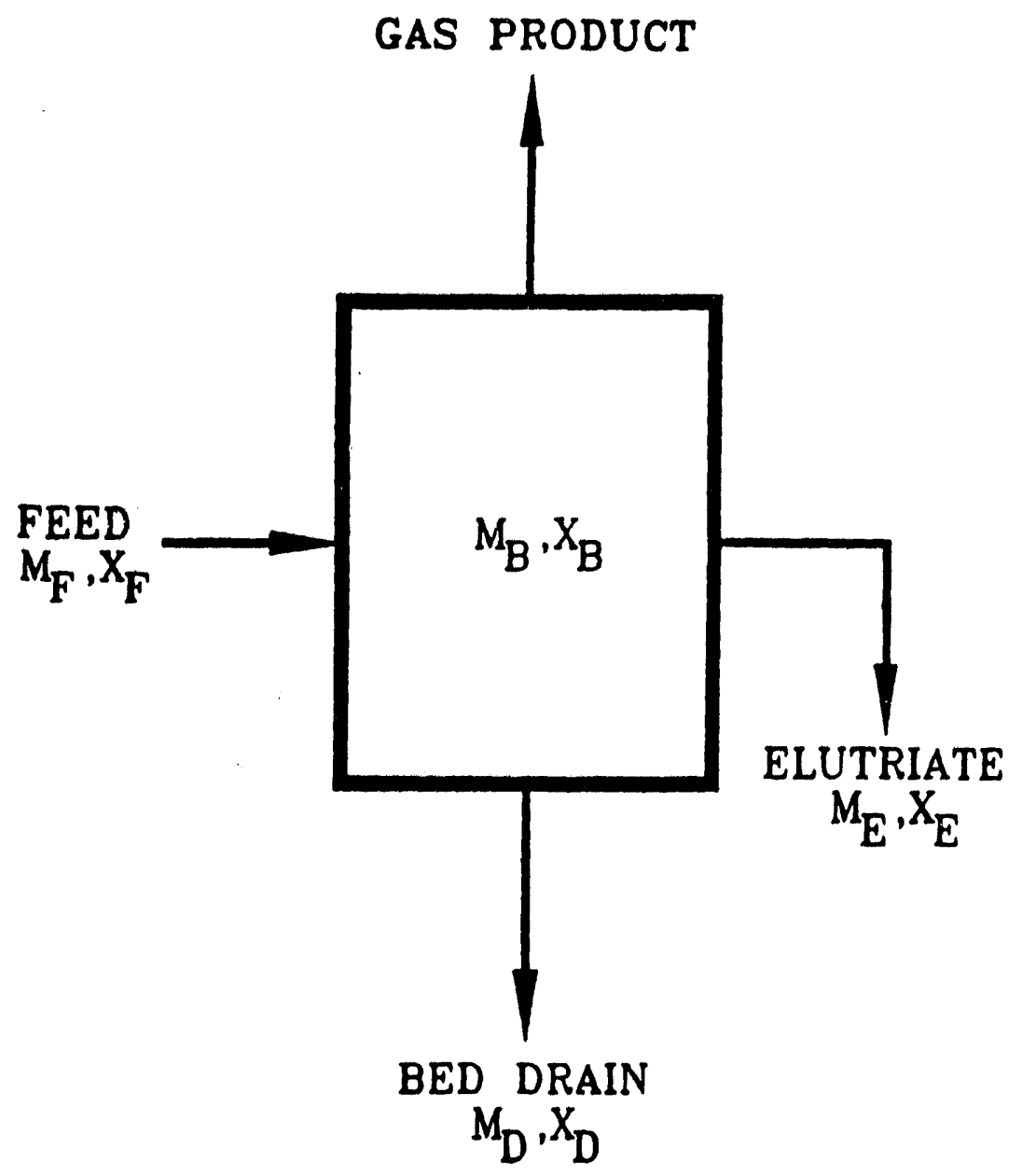

FIGURE 4-2: GASIFIER MATERIAL BALANCE

$X_{F}, X_{B}, X_{E}$ and $X_{D}$ are the carbon fraction in the feed, elutriate, drain, and bed material respectively;

$M_{B}$ is the total bed mass;

$k$ is the specific gasification rate constant which includes all fixed variables and necessary unit conversions.

In this calculation, "carbon" refers to all gasifiable components while "ash" refers to all ungasifiable components. The stream of elutriate can be 
eliminated by returning it to the gasifier, but the bed drain must be maintained to balance the input ash in the feed material.

Under the conditions of $M_{E}=0$ and $X_{D}=X_{B}$, the carbon balance becomes

$$
M_{F} X_{F}=k M_{B} X_{B}+M_{F} \frac{\left(1-X_{F}\right)}{\left(1-X_{B}\right)} X_{B}
$$

In the above equation the first term at the right side represents the production rate and the second term is the loss of unconverted carbon in the bed drain (L).

When the bed carbon concentration is raised by $\Delta X_{B}$, the production will increase by $k M_{B} \Delta X_{B}$, while the loss of unconverted carbon will be increased by

$$
\Delta L=M_{F}\left(1-x_{F}\right) \cdot \frac{\Delta x_{B}}{\left(1-x_{B}\right)^{2}}
$$

It can be seen that the rate of increase in the loss is greater than the rate of increase in the production since the denominator $\left(1-X_{B}\right)$ is always less than 1 . However, under many circumstances the increase in loss of unconverted carbon can be compensated by the increase in the gas production rate because the economic value of the product gas is higher than that of the feed material. When the bed concentration reaches certain levels, the increase in product gas cannot compensate the increase in loss of unconverted carbon, increasing the bed carbon concentration will not be beneficial unless some kind of separation of char from ash and reinjection of the separated char into the reactor is applied. This is essentially accomplished by recycling first-stage cyclone catch into the reactor.

\subsubsection{REActivity OF FEedstock}

The reactivity of feed material differs from one to the other. Lignite and porous mildly pyrolyzed char are very active while the ash concentrate from coal liquefaction has much lower reactivity. To attain a high production rate of a 
given gasifier under mild operation conditions, feeding highly reactive material is desirable.

For the sake of energy recovery from the liquefaction residue, the ash concentrate has to be consumed. Ash concentrate may be gasified at the same high production rate as the more reactive feedstock but under more intensive operation conditions. A feed consisting of a blend of ash concentrate and coal or char is the proposed first choice. The ratio of the two components should be carefully chosen according to their reactivity and required gas production rate so that neither of the components would accumulate or deplete in the reaction bed.

\subsubsection{Operating Temperature}

Higher reactor temperature promotes the gas production rate. However, increased operating temperature results in increased sensible heat losses from product and flue gas. Of course, the heat losses may be partially offset by the benefits of increased carbon to gas conversion efficiency.

Calculations suggest that an increase in gasifier temperature of $100^{\circ} \mathrm{F}$ may translate into a reduction in cold gas thermal efficiency of 5 to 6 percent, assuming that carbon conversion levels and other process variables are unchanged. As an example, heat and material balances were prepared for simulated indirect gasification conditions at thrue separate temperatures $\left(1500^{\circ} \mathrm{F}, 1600^{\circ} \mathrm{F}\right.$ and $\left.1700^{\circ} \mathrm{F}\right)$. The feedstock was assumed to consist of a typical Wilsonville ash concentrate formed from a bituminous coal. In all cases, the flue gas temperature approach at the exit of the immersed heat exchanger was taken to be $1000^{\circ} \mathrm{F}$, and the combustor was assumed to be fueled by a portion of the product gas and operated at 10 percent excess air. A 4 percent char loss was also assumed.

The resulting cold gas thermal efficiencies for each case are shown in Table 4-5. Based on this calculation, operating conditions should be selected at the minimum gasifier temperature supporting reasonable levels of char conversion, efficiency and throughput. The optimum balance between these factors can be accurately estimated based on experimenting with a given gasification system. Apparentiy, a range of $1350^{\circ} \mathrm{F}$ to $1550^{\circ} \mathrm{F}$ is a reasonable choice based on 
the preliminary test data. The lower 1 imit can be applied for the highly reactive feed materials such as lignite and coal char; the high limit should be applied for the less active feedstock such as ash concentrates.

TABLE 4-5:

Simulated Cold Gas thermal efficiency as a EUNCTION OF INDIRECT GASIFIER TEMPERATURES

IEMPERATURE ( $\cdot$ E) COLD GAS EFFICIENCY (\%)

1500

65.0

1600

59.1

1700

52.5

\subsubsection{Use of Catalysts, Sorbents, and Inert Ballast}

An option exists for employing catalysts or sorbents in the MTCI indirect fluid bed for the purpose of enhancing reactivity and/or product quality. A variety of alkaline catalysts have been demonstrated to improve reactivity of carbon-steam reactions and to reduce the breakthrough of hydrocarbons, tars, and oils. These catalysts have a most pronounced effect when they are impregnated or otherwise intimately mixed with the feedstock. This is due to the fact that volatile matter released from the intra-particle regions of the coal/char matrix are rapidly broken down into light gases which escape before secondary condensation or coking reactions occur within the pore structure. This results in the production of a more reactive and porous char and reduction in the hydrocarbon content of product gases.

When the catalytic substrates are not intimately mixed with the feedstock, their ability to influence primary reactions within the coal/char matrix is limited. In these cases, the catalysts act to enhance reactivity between steam and hydrocarbons in the gas phase region external to the coal/char matrix. This results in improved product gas quality, but has a limited effect on the fundamental steam-char reactivity. 
In the case of mild gasification chars containing a minimum quantity of volatile matter, the potential for significantly enhancing reactivity and gas quality through the use of catalytic agents is questionable. As previously discussed, the primary mechanism for catalytic enhancement requires participation of gas phase hydrocarbons. Since pyrolytic decomposition of the char to higher hydrocarbons is anticipated to be significantly less pronounced than for volatile coals, the influence of catalytic promoters in also expected to be less important.

In the test of char gasification, very little effect could be observed of bed materials on the gas production. However, in the tests for the feed materi. als with higher volatile contents (i.e., lignite and ash concentrate) the increase in gas production due to the use of 1 imestone bed material was obvious. By inspecting the bed samples taken during the gasification test it can be seen that the limestone bed sample had very little carbon deposited on its surface, indicating its ablifty to accelerate the carbon-steam reaction on the surface. The sand bed sample had appreciable amounts of carbon deposited on its surface, indicating the lack of catalytic effect of the sand bed material.

\subsubsection{Heat Transfer Limitations}

The gasifier may be said to be reactivity limited, if operating conditions are such that throughput is 1 imited by resulting char conversion levels below some minimum acceptable level. Conversely, the indirect gasifier may be heat transfer limited when the throughput dictates heat transfer surface in excess of that which can be practically accommodated within the gasifier volume.

The required absorbed duty to be transferred to the gasifier through the heat exchange surface translates to approximately 5,000 Btu per pound MaF char. If it is assumed that the indirect pulse fire tubes are constructed from 1 -inch pipe on 2-inch center-to-center spacing, then the volumetric heat transfer surface density is approximately $9.4 \mathrm{ft}^{2} / \mathrm{ft}^{3}$. Experience has shown that practical heat fluxes of $15,000 \mathrm{Btu} / \mathrm{hr} / \mathrm{ft}^{2}$ can be achieved in the atmospheric pulsating heat exchange system. 
By combination of these values, the maximum heat transfer limited, spectfic throughput $W_{h}$ is given by:

$$
\begin{aligned}
& W_{h}=\frac{\left(9.4 \mathrm{ft}^{2} / \mathrm{ft}^{3}\right)\left(15,000 \mathrm{Btu} / \mathrm{hr} / \mathrm{ft}^{2}\right)}{(5,000 \mathrm{Btu} / \mathrm{lb})} \\
& \text { - } 28.2 \mathrm{lb} / \mathrm{hr} / \mathrm{ft}^{3}
\end{aligned}
$$

A combination of this result with those of Table 5-4 is shown in Eigure 4-3. The figure suggested that for operation at or near atmospheric pressure, the indirect gasifier would be heat transfer 1 imited (rather than reactivity 1 imited) for temperatures above approximately $850^{\circ} \mathrm{C}$. Note that $950^{\circ} \mathrm{C}$ is considered to be the maximum practical operating temperature due to material limitations. For pressures within the gasifier above $1 \mathrm{~atm}$, the gasifier appeared to be 1 imited by heat transfer constraints for all temperatures, resulting in a maximum achiev-

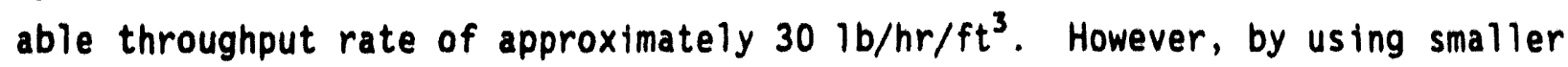
fluidizing particles in the bed (mean particle size of about 127 microns) the bed-side heat transfer coefficient was actually increased to about $200 \mathrm{Btu} /$ $\mathrm{hr} / \mathrm{ft} /{ }^{\circ} \mathrm{F}$ in field tests of the MTCI gasifier PDU at Inland Container, Ontario, California (July 1992). Hence, specific throughput although ultimately limited by the bed-side heat transfer would not be 1 imited to the $30 \mathrm{lb} / \mathrm{hr}^{-\mathrm{ft}^{3}}$ as earlier thought.

For a pressurized pulse combustor, the temperature of the flue gas been estimated to be approximately $1600^{\circ}$ to $1700^{\circ} \mathrm{F}$ and could, if required, then be expanded directly into a gas turbine for generating electricity and/or compress. ing the air required for combustion. 


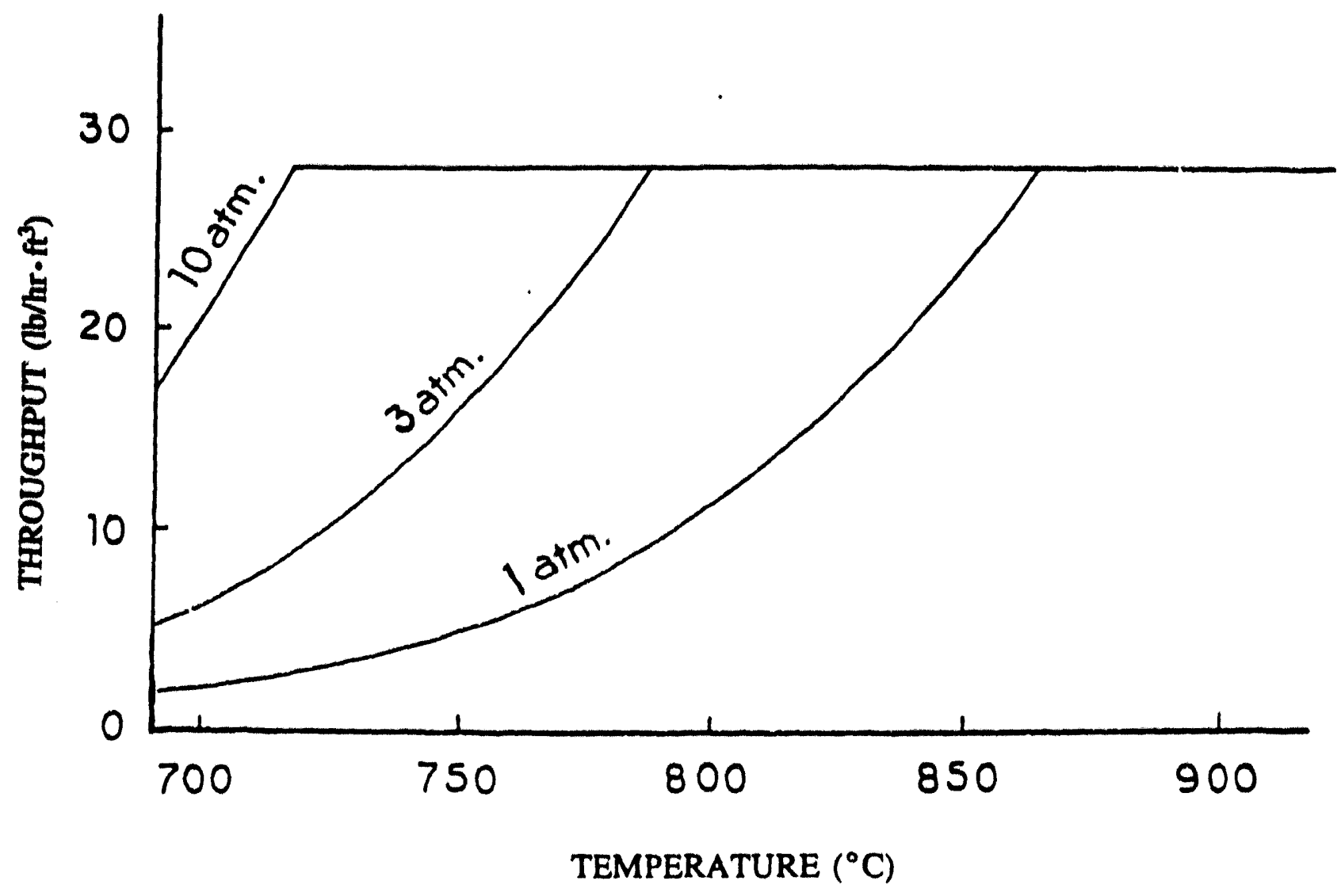

FIGURE 4-3: THROUGHPUT OF INDIRECT GASIFICATION REACTOR 


\section{SECTION 5.0}

\section{ENGINEERING ANALYSIS OF A CONCEPTUAL 300-TPD CHAR INDIRECT GASIEICATION PLANT FOR HYDROGEN PRODUCTION}

A process flow diagram for the conceptual $p$ lant is provided in Eigure 5-1. The flow streams are primarily as described in Section 3.2. Iable 5-1 provides a material balance showing mass flows for each major process stream.

The material balance is based on the char composition shown in Table 3-6. The plant char feed capactty is 300 TPD. Four percent char losses are assumed and the gasifier combustor is fueled with recycled product gas.

The gasification plant produces 7.73 MMSCFD of hydrogen product. The hydrogen yield is $28.44 \mathrm{SCF} \mathrm{H}_{2}$ per pound of feed carbon (or $0.15 \quad \mathrm{Ib} \mathrm{H}_{2} / 1 \mathrm{~b}$ feed carbon). Recall that these yields can be substantially enhanced by utilizing char directly as a fuel source.

Major equipment for the 300-TPD char gasification plant is listed in Iable 5-2. Iable 5-3 presents the major design parameters for the pulsed combustor, the gasifier heating tube bundles, and the gasifier fluidized bed. Design parameters for other equipment are listed in Iables 5-4, 5-5, and $\underline{5-6}$.

A capital cost estimation was calculated for a scaled-up 3,000 tons feed char per day hydrogen plant utflizing the MTCI indirect gasification technology. The plant was approximately in the same scale as the oxygen-blown gasification plant discussed in Section 3.1. The cost of the gasifier was estimated by scaling up an existing black liquor gasifier design. The estimated capital cost is listed in Iable 5-7, together with the capital cost of the oxygen-blown hydrogen plant discussed in Section 3.1 for comparison. The capital cost estimate includes the gasification plant and peripherals only - it does not include the power generation facility. 

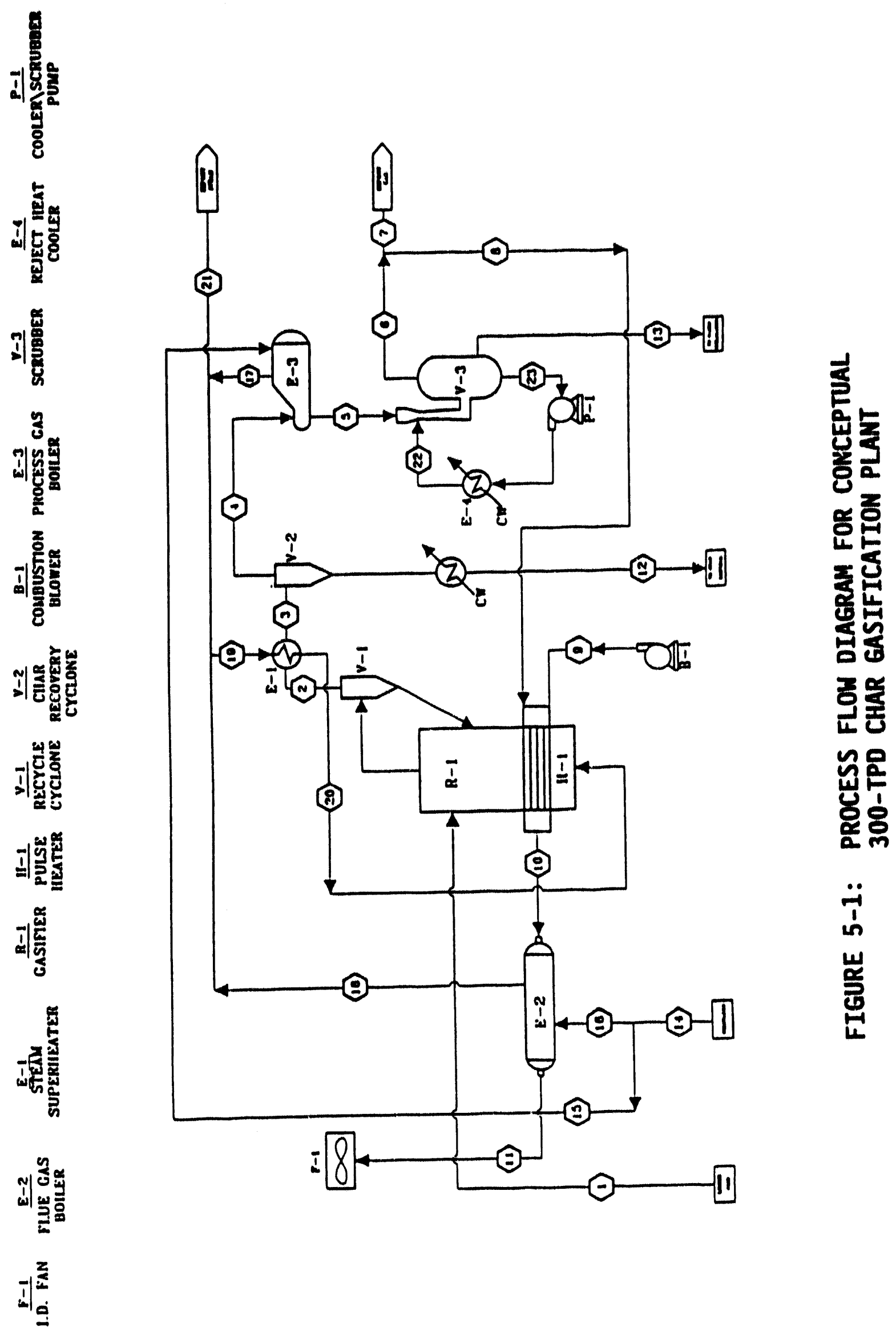


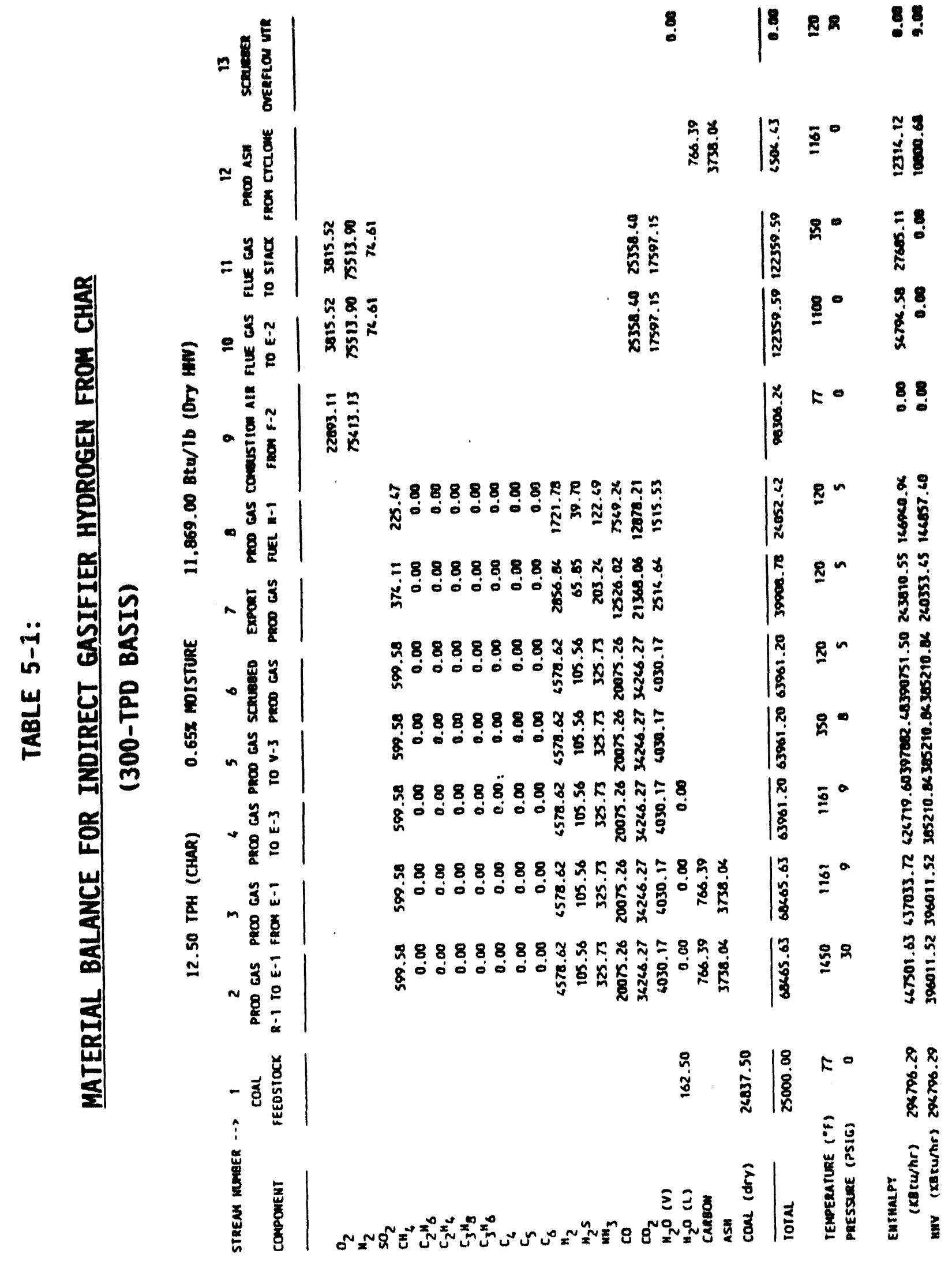



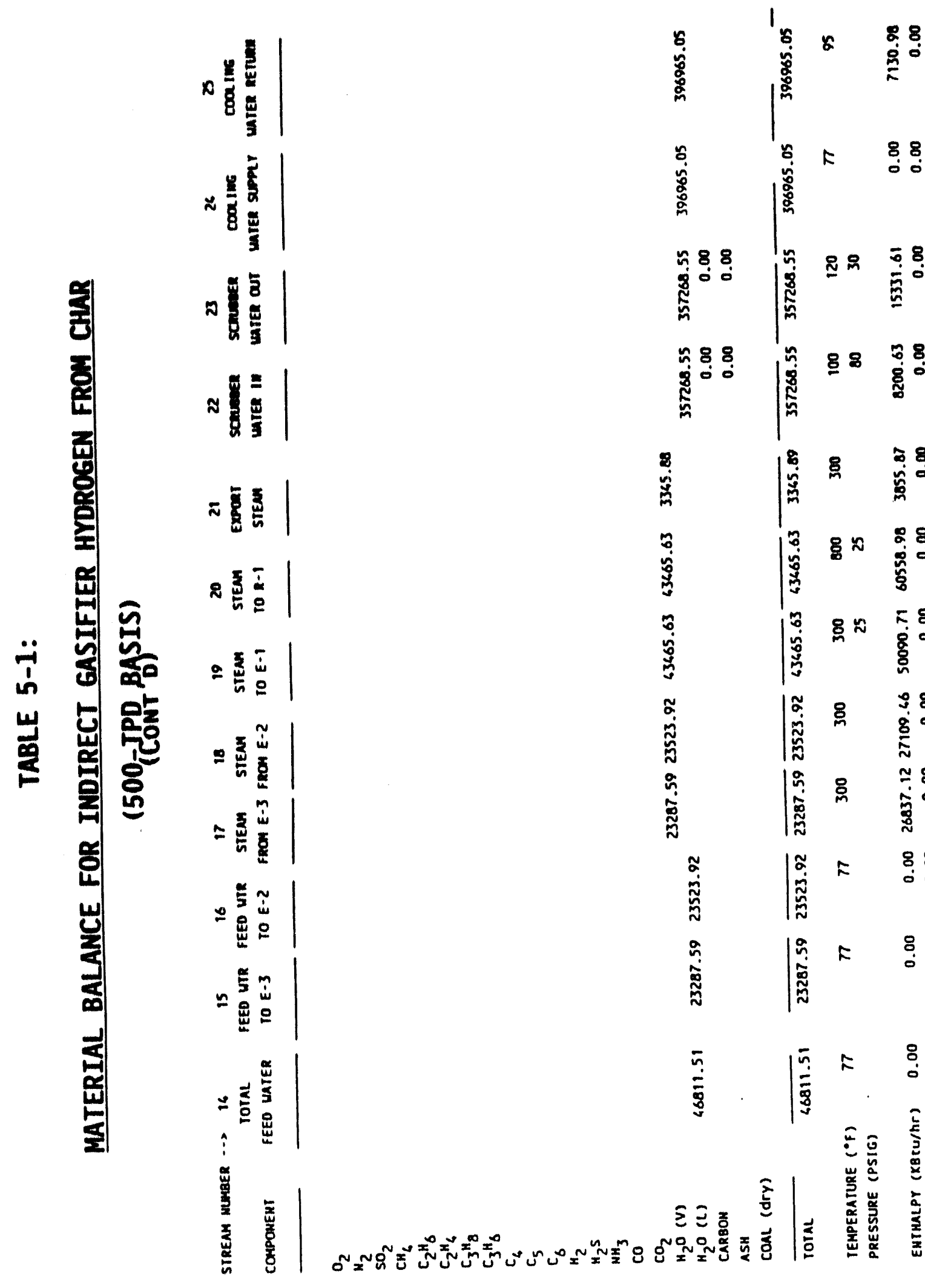

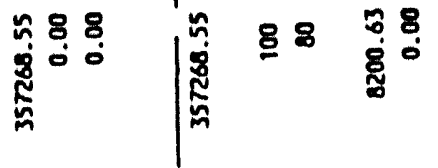

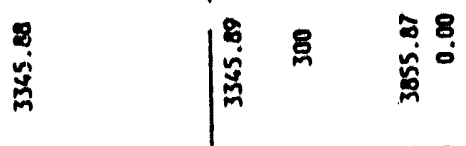

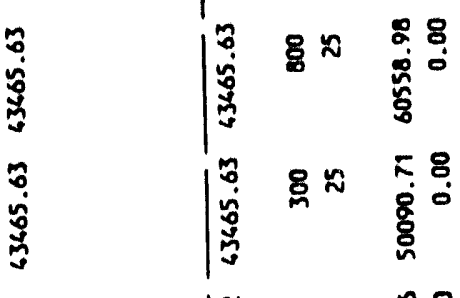

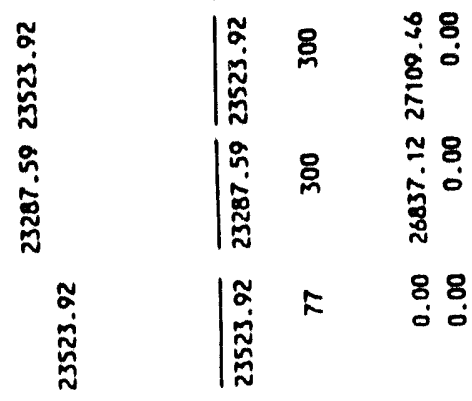

商

言

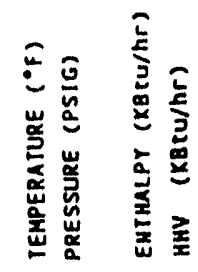


TABLE 5-2:

\section{MAJOR EQUIPMENT LIST FOR 300-T/D CONCEPTUAL DESIGN}

$\begin{array}{ll}R-1 & \text { GASIFIER } \\ V-1 & \text { RECYCLE CYCLONE } \\ V-2 & \text { CHAR RECOVERY CYCLONE } \\ V-3 & \text { SCRUBBER } \\ H-1 & \text { PULSE HEATER } \\ E-1 & \text { STEAM SUPERHEATER } \\ E-2 & \text { FLUE GAS BOILER } \\ E-3 & \text { PRODUCT GAS BOILER } \\ E-4 & \text { SCRUBBER WATER COOLER } \\ B-1 & \text { COMBUSTOR AIR BLOWER } \\ \text { P-1 } & \text { SCRUBBER WATER PUMP } \\ \mathrm{F}-1 & \text { ID FAN }\end{array}$


TABLE 5-3:

\section{PULSED INDIRECT GASIFIER DESIGN CRITERIA}

COMBUSTOR

COMBUSTOR FIRING RATE (MMBtu/hr)

VOLUMETRIC HEAT RELEASE (MMBtu/ $\mathrm{ft}^{3} / \mathrm{hr}$ )

146.9

NUMBER OF AEROVALVES

AEROVALVE THROAT DIAMETER (inch)

COMBUSTOR HEAT LOSS

TUBE BUNDLE

NOMINAL TUBE DIAMETER (inch)

TUBE LENGTH ( $\mathrm{ft}$. )

NUMBER OF TUBES

NUMBER OF 61-TUBE BUNDLES

1836.7

FIRING RATE PER TUBE (KBtu/hr)

30.1

TOTAL TRANSFERRED DUTY (MMBtu/hr)

80.0

AVERAGE TUBE HEAT FLUX (Btu/ $\mathrm{ft}^{2} / \mathrm{hr}$ )

92.1

9200

\section{GASIFIER}

DESIGN TEMPERATURE

INTERNAL ( $\left.{ }^{\circ} \mathrm{F}\right)$

1450

$\operatorname{SKIN}\left({ }^{\circ} \mathrm{F}\right)$

DESIGN PRESSURE

BED (psig)

FREEBOARD (psig)

OPERATION PRESSURE

BED (psig) 30

FREEBOARD (psig) $\quad 25$

SUP. FLUIDIZATION VELOCITY (FPS) 
TABLE 5-4:

SPECIFICATIONS AND DUTIES FOR HEAT EXCHANGERS

E-1 STEAM SUPERHEATER

FLUID

FLOW RATE (1b/hr)

INLET TEMPERATURE $\left({ }^{\circ} F\right)$

EXIT TEMPERATURE $\left({ }^{\circ} \mathrm{F}\right)$

DUTY (MMBtu/hr)

\section{E-2 FLUE GAS BOILER}

FLUID

FLOW RATE (1b/hr)

INLET TEMPERATURE $\left({ }^{\circ} \mathrm{F}\right)$

EXIT TEMPERATURE $\left({ }^{\circ} \mathrm{F}\right)$

DUTY (MMBtu/hr)
SHELL SIDE

Prod. Gas

68,500

1450

1161

$$
\begin{array}{r}
\text { Water/Steam } \\
23,500 \\
77 \\
300
\end{array}
$$

Water/Steam

23,300

77

300
TUBE SIDE

Steam

43,500

300

10.5

\section{E-3 PRODUCT GAS BOILER}

FLUID

FLOW RATE (1b/hr)

INLET TEMPERATURE $\left({ }^{\circ} \mathrm{F}\right)$

EXIT TEMPERATURE ('F)

DUTY (MMBtu/hr)

\section{E-4 SCRUBBER WATER COOLER}

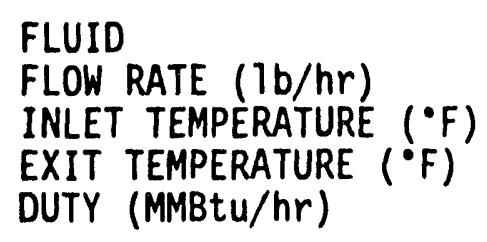

27.0

350

Prod. Gas

63,961

1161

26.8

Scrubber Water 357,000 120

7.13 
TABLE 5-5:

\section{SPECIFICATIONS FOR PUMPS AND BLOWERS}

B-1 COMBUSTOR AIR BLOWER

FLUID

FLOW RATE (inlet, ACFM)

INLET TEMPERATURE ( $\left.{ }^{\circ} F\right)$

DIFFERENTIAL PRESSURE (psi)

$$
\begin{array}{r}
\text { Air } \\
20,382 \\
70 \\
5
\end{array}
$$

\section{P-1 SCRUBBER WATER PUMP}

FLUID

FLOW RATE (GPM)

INLET TEMPERATURE ( $\left.{ }^{\circ} F\right)$

DIFFERENTIAL PRESSURE (psi)
Scrubber Water

793

120

40

\section{F-1 I.D. FAN}

FLUID

FLOW RATE (exit, ACFM)

INLET TEMPERATURE ( $\left.{ }^{\circ} \mathrm{F}\right)$

DIFFERENTIAL PRESSURE (psi) 
TABLE 5-6:

\section{SPECIFICATIONS FOR VESSELS}

\section{$V-1$ RECYCLE CYCLONE}

OPERATION PRESSURE (psig) OPERATION TEMPERATURE ('F) FLUID FLOW RATE (ACFM) SOLID LOAD (1b/hr)

\section{V-2 CHAR RECOVERY CYCLONE}

OPERATION PRESSURE (psig) OPERATION TEMPERATURE $\left({ }^{\circ} F\right)$ FLUID

FLOW RATE (ACFM)

SOLID LOAD ( $\mathrm{lb} / \mathrm{hr})$

$$
\begin{array}{r}
30 \\
1450 \\
\text { Product Gas } \\
24,200 \\
13,500
\end{array}
$$

$$
\begin{array}{r}
30 \\
1161 \\
\text { Product Gas } \\
24,200 \\
4,500
\end{array}
$$

\section{V-3 SCRUBBER}

OPERATTON PRESSURE (psig)

OPERATION TEMPERATURE ( ${ }^{\circ} \mathrm{F}$ )

FLUID

CIRCULATION FLOW RATE (GPM) 
TABLE 5-7:

\section{CAPITAL COST ESTIMATE FOR TWO HYDROGEN PLANTS} (IN MILLIONS OF 1991 DOLLARS)

\begin{tabular}{lcc} 
& OXYGEN BLOWN & MTCI INDIRECT \\
\cline { 2 - 3 } FEEDSTOCK HANDLING & 39.6 & 10 \\
OXYGEN PRODUCTION & 83.8 & 0 \\
GASIFICATION & 94.7 & 55 \\
$\begin{array}{l}\text { PRODUCT GAS TREATING } \\
\text { (including COMPrESSion) }\end{array}$ & 29.6 & 35 \\
ACID GAS REMOVAL & 17.7 & 12 \\
SULFUR RECOVERY & 12.1 & 12 \\
TAIL GAS TREATING & 5.9 & 6 \\
GENERAL FACILITIES & & \\
(aS 28.6\% CaPITaI) & 114.3 & 52.5 \\
INITIAL MATERIALS & $\underline{1.2}$ & 1.2 \\
TOTAL & $\underline{398.9}$ & $\underline{183.5}$ \\
\hline
\end{tabular}


It can be seen from Table 5-7 that the estimated capital cost of the MTCI indirect gasification hydrogen plant is 54 percent less than the estimated capital cost of the oxygen-blown gasification hydrogen plant. Assuming an annual fixed operation and maintenance cost of 3.8 percent the capital cost and a 15 percent of capital carrying charge, the annual cost of running the hydrogen plant based on the MTCI indirect gasification technology will be 34.5 million dollars per year exclusive of feedstock charge. Compared with the annual cost of the sample oxygen-blown hydrogen plant (88.1 million dollars annually), this is a 61 percent reduction of hydrogen production cost. 
Indirectly heated gasification systems have the advantage of minimizing product gas contamination resulting from the presence of combustion or autothermal partial oxidation products in the gasification process. However, the highly endothermic nature of the gasification reaction requires that large amounts of heat be transferred to the reacting feedstock. Systems which employ conventional fire-tube heat exchangers are found to be heat-transfer 1 imited. This requires a large number of tubes with a large surface area immersed in the fluid bed. This significantly increases the size of the reactor or reduces reactor throughput and leads to fluidization problems and high reactor material and fabrication costs.

Heat-transfer limitations of indirectly heated systems which employ conventional fire-tube heat exchangers stem from the low heat transfer coefficients at the flue gas side of the fire tube. Employing the resonance tube(s) of a pulse combustor as fire tubes dramatically enhances the heat transfer coefficients on the flue gas side of the fire tubes. The simplicity and high-performance characteristics of the MTCI reactor technology provide significant cost, performance, and energy efficiency advantages over the existing state-of-the-art alternatives. The technology is suited for a wide range of indirectly heated reactor system designs and for a wide spectrum of applications.

In this program, MTCI demonstrated the feasibility of its technology for the production of a synthesis gas from liquefaction by-products, and char, subbituminous and bituminous coal.

Initial efforts to obtain a mild gasification char were unsuccessful and the scope of the program was expanded to include the processing of a subbituminous coal (Black Thunder and Eagle Butte mines) to produce the mild gasification char required to conduct the experimental activities. The MTCI system was configured for the mild gasification process and successfully produced a suite of products 
including the char required for the experimental program. Later on in the project, AMAX Research and Development Company provided a feed char that was originally generated by the Western Research Institute and then further gasified by AMAX. This char was used in a long duration test. In addition to preparing mild gasification char for the required series of tests, an additional test for the direct gasification of the subbituminous coal was also conducted success. fully.

Tests were successfully conducted for the gasification of ash concentrate (SRC) from Southern Electric International, Southern Clean Fuels Division (SCFD). The ash concentrate was the residue of the coal liquefaction test run by SCFD.

All of the test activities for: mild gasification to produce a char; the steam reforming of char; ash concentrate and subbituminous coal were successful and prompted an additional set of tests for the steam-reforming of a bituminous coal that included preconditioning and gasifying a Pittsburgh \#8 coal feed and preparing a process design for the concept. As shown in Iable 6-1, the major constituents of the Product $\mathrm{Gas}$ were $\mathrm{H}_{2}, \mathrm{CO}$, and $\mathrm{CO}_{2}$ with the composition for those constituents for most process variables in a range not different from that experienced in the processing of other feedstocks such as biomass and waste materials. Previous tests on lignite are included to indicate the relative invariance of the product gas composition to feedstocks.

A process evaluation of hydrogen production from direct liquefaction restdues, char and coal was made based on the preliminary data base acquired in the characterization tests. The process evaluation focused primarily on the gasifier train and included a consideration of design trade-offs and their impact on economics and performance of a plant.

A comparative economic analysis of partial oxidation coal gasification plants was derived from assessments conducted by Fluor Engineers for the Coolwater coal gasification facility that incorporated a Texaco oxygen-blown coal gasifier. The capital and operating cost data was provided for the integrated gasification-combined cycle (IGCC) plant in 1984 dollars. The base cost estimate, known as the "Unphased GCC. Plant," was utilized to provide an estimate of 


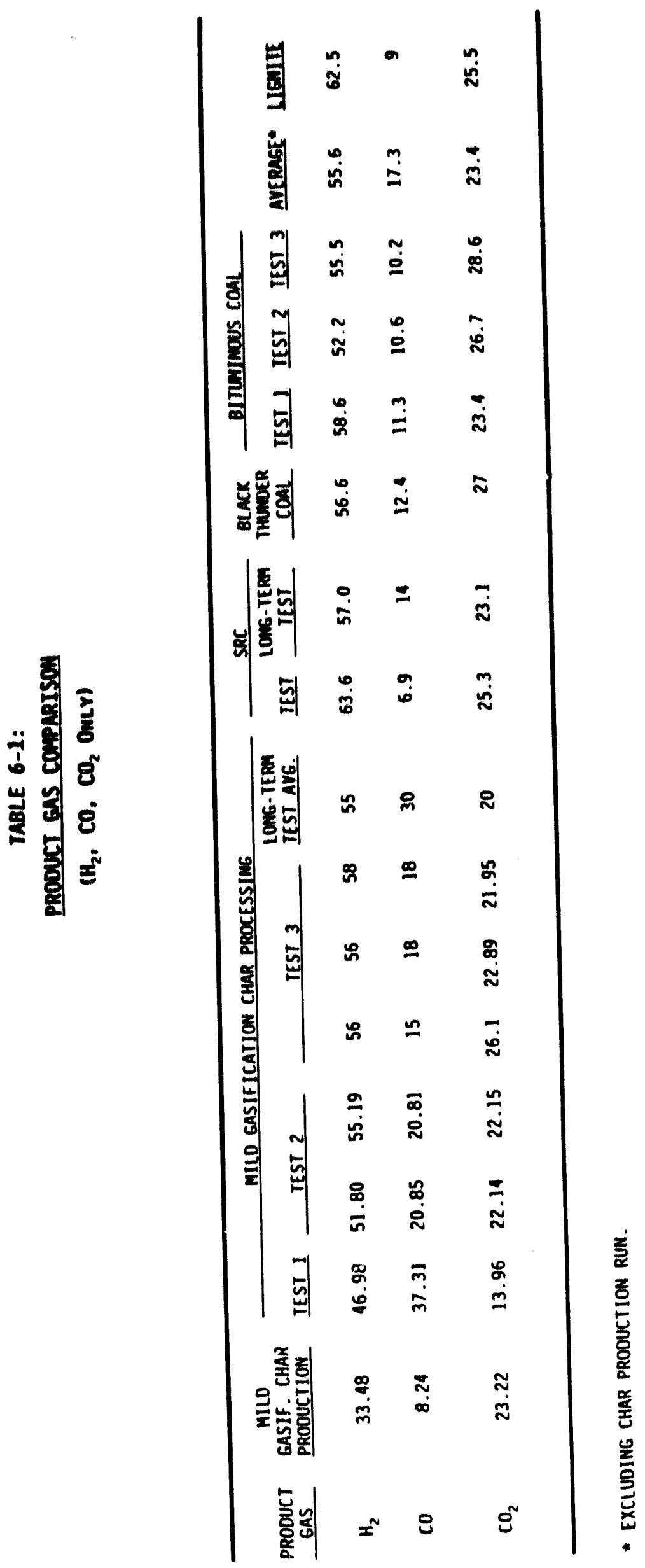


the overall capttal and operating costs of a Texaco oxygen-blown gasifier and its peripherals and to determine the proportion of these costs attributed to the oxygen production system. Sufficient detall was provided for most of the cost data to separately identify the cost of the gasification system and its peripherals, including the oxygen plant.

A capital cost estimation was calculated for a scaled-up 3,000 tons feed char per day hydrogen plant utilizing the MTCI indirect gasification technology. The plant was approximately to the same scale as the oxygen-blown gasification plant analyzed by Fluor Engineers. The cost of the MTCI gasifier was est imated by scaling up an existing black liquor gasifier design. The capital cost esti. mates included the gasification plant and peripherals only and did not include the power generation factlity.

The estimated capital cost of the MTCI indirect gasification hydrogen $p 1$ ant is 54 percent less than the estimated capital cost of the oxygen-blown gasification hydrogen plant. Assuming an annual fixed operation and maintenance cost of 3.8 percent of the capital cost and 15 percent for a capital carrying charge, the annual cost of running the hydrogen plant based on the MTCI indirect gasification technology would be 34.5 million dollars per year exclusive of feedstock charge. Compared with the annual cost of the sample oxygen-blown hydrogen plant (88.1 million dollars annually), this is a 61 percent reduction in hydrogen production cost.

Based on this work and the literature, it was evident that oxygen costs have an enormous impact on the total hydrogen production costs for partial oxidation gasifier systems. The indirect gasification process does not require consumption of oxygen and appears to have the potential to reduce hydrogen production costs by over 30 percent.

However, an independent study by AMOCO using the MTCI data and comparing the MTCI system with the Texaco gasifier arrived at a different conclusion, i.e., that a low-cost, high-pressure gasifier would be necessary to compete successfully with the Texaco system primarily by eliminating the expensive crude gas compression requirement. Unfortunately, attempts at reconciling the differences, 
there was actually only one that appeared to be the cost driver, i.e., the cost of power generation and/or power requirements, that far outweighed any other cost differences and therefore led to the conclusions drawn by the AMOCO analyst, who is no longer employed by AMOCO. On the other hand, a study on the production of hydrogen from biomass and coal completed in $1993^{(15)}$ also using ASPEN seems to be in agreement with the MTCI and other studies.

Key conclusions from the program are summarized as follows:

- By avoiding the use of cryogentc oxygen and enhancing hydrogen yield per pound of char, over 60 percent reduction in hydrogen production costs can be achieved.

- The MTCI indirect gasifier has the potential to increase hydrogen yield by 10 percent and reduce $\mathrm{CO}_{2}$ removal requirements by 40 percent compared to alternative partial oxidation gasifiers.

- 96 percent of gasification efficiency is easily achievable in the MTCI indirect gasifier.

- The MTCI gasifier characterizes its low liquid by-product yield.

- Limestone bed material is highly recommended especially for gasifying ash concentrate.

- Gasifier can be operated at a relatively mild temperature range of $1350^{\circ} \mathrm{F}$ - $1450 \%$ for char and 1 ignite feedstocks. For ash concentrate feedstock, higher gasifier temperatures $\left(1500^{\circ} \mathrm{F}\right)$ are recommended as well as co-gasifying char.

- A pressurized system could provide additional benefits in yield and lowered capital cost as well as process advantages for IGCC systems.

The indirect gasification process offers a unique potential for significantiy reducing the cost of hydrogen production from ash concentrates or mild gasification chars at atmospheric pressures and even greater potential as a pressurized system. By avoiding the need for a cryogenic oxygen plant, the capital cost of the gasification facility can be reduced by 25 percent when operating costs for the cryogenic plant are included even with the compression costs necessary for the atmospheric system. This would translate to a reduction in total hydrogen production costs of approximately 30 percent. 
Furthermore, the indirect gasifier shows potential for increasing hydrogen yield by 10 percent and reducing acid gas removal requirements by 40 percent. This alone is estimated to provide additional cost savings of up to 10 percent.

Since hydrogen production accounts for a significant fraction of total cost for a direct 1 iquefaction facility, the indirect gasifier is anticipated to offer a unique opportunity for improving the economics of premium liquid production from the nation's huge coal resources. 


\section{REFERENCES}

1. Assessment of Coal Liquefaction Research Needs: Report on First Meeting of Expert Panel Held in Pittsburgh, Pennsylvania, January 5-6, 1988, submitted to U.S. Department of Energy (DOE) by Science Applications International Corporation, February 12, 1988, DOE Contract No. DE-ACO1-87ER30110, February 1988.

2. An Innovative System for Biomass Thermochemical Conversion, Management and Technical Consultants, Inc., Final Report, April 1987, DOE/SBIR No. DEACO5-84ER80176.

3. Testing of an Advanced Thermochemical Conversion Reactor System, Manufacturing and Technology Conversion International, Inc., Final Report, April 1989, California Energy Commission Contract No. 500-86-012, and DJOE/PNL Contract No. B-L7109-A-Q.

4. Plackett, R.L., and Burman, J.P., "The Design of Optimum Multifactorial Experiments," Biometrika, 33:305-325 (1946).

5. Sears, R.E., R.C. Timpe, S.J. Galegher, and W.G. Wilson, A.C.S. Division of Fuel Chemistry, Anaheim Meeting, 31(3):116-175, September 1986.

6. C.W. Lee and R.G. Jenkins, "Effect of Acid Treatment Atmosphere on the Thermoplasticity of a Low-Volatile Bituminous Coal." Energy and Fuels, $\underline{\mathbf{3}}: 703-706,1989$.

7. S.R. Taylor, K.J. Miller, and A.W. Deurbrouck, in: B.R. Cooper and L. Petrakis (eds.), Chemistry and Physics of Coal Utilization - 1980, American Institute of Physics, New York, 1980, 334.

8. M. Seki, D. Ito, and M. Lino, "Effect of Acetylation on Caking Properties of Bituminous Coals," Energy and Fuels, 4:352-355, 1990.

9. F.E. Huggins, et al., "Low-Temperature Oxidation of Bituminous Coal: Its Detection and Effect on Coal Conversion," Fuel Proc. Tech., 15:233-244, 1987.

10. M. Seki, 0. Ito, and M. Lino, "Effect of Mild Oxidation of Bituminous Coals on Caking Properties," Fuel, 69:317-321, 1990.

11. M. Seki, 0. Ito, and M. Lino, "Effect of Oxidation of Caking Properties: Oxidation of Extract and Residue," Fuel, 69:1047-1051, 1990.

12. M.J. Mulligan and K.M. Thomas, "Some Aspects of the Role of Coal Thermoplasticity and Coke Structure in Coal Gasification," Part 3, Fuel, 66: 1289-1298, 1987 .

13. P.D. Green, et a1., "Coal Thermoplasticity and Coke Structure as Related to Gasification: Effect of Inorganic Additives on High Pressure Dilatometric Properties and Reactivity Towards Hydrogen," Fuel, 67:389-395, 1988. 
14. H.H. Lowry (ed.), Chemistry of Coal Utilization, Vol. 1, Ch. 18, pp. 627$696,1945$.

15. Planning Data Book for Gasification-Combined Cycle Plants: Phased Capacity Additions, EPRI Report No. AP-4395, Fluor Engineers, Inc., January 1986.

16. Reed, C.L., and C.J. Kuhre, Chemical Feedstocks from Partial Oxidation of Hydrocarbons, She11 0il Company, 175th AIChE National Meeting, Anaheim, California, March 1978.

17. Kardofsky, et. al., "The Production of Fluid Fuels from Biomass, "Princeton University, June 1993 (Master Thesis).

18. Zahradnik, R. and Turdera, "Feasibility Evaluation and Conceptual Design of a Pulse Tube Combustion System for a Commercial-Scale Integrated Coal Gasification Cycle (IGCC) Power Plant," K\&M Engineering and Consulting Corporation, April 1992.

19. Solar Turbines Final Report. 


\title{
APPENDIX A
}

\section{ECONOMIC EVALUATION OF MTCI GASIFIER FOR HYDROGEN PRODUCTION}

\author{
J.D. FOX \\ AMOCO OIL COMPANY \\ Research and Development Department
}

AMOCO CORPORATION

Alternative Fuels Development 
R.E. Lumpkin Solid Resources

\section{Amoco Corporation}

305 East Shumian Boulevard

Suite 600

Naperville, Illinois 60563-8408

Alternative Feedstock Development Department 708-717.2447

FAX: $708-717-2430$

January 22, 1992

Dr. K. Durai-Swami

MTCI, Inc.

13080 Park Street

Santa Fe Springs, CA 90670

Dear Dura1:

\section{Economic Evaluation of MTCI Gasifier for Hydrogen Production}

Amoco appreciates the opportunity we've had to assist MTCI evaluate the application of your indirectly heated gasifier to the production of hydrogen for direct coal gasification. As was agreed, Amoco has provided in-kind cost sharing for your DOE contract by performing technical and economic evaluation of the application.

Enclosed is a report by Amoco's J.D. Fox which compares a conceptual process based on MTCI's gasifier with Texaco's gasifier for the production of high-pressure hydrogen of direct coal liquefaction. The analysis includes sensitivity studies on several process options and yield improvements. It concludes that hydrogen produced by the MTCI process is at least $30 \mathrm{z}$ more expensive than that from the Texaco process.

For MTCI's process to be competitive, a low cost, high pressure gasifier is necessary; crude gas compression costs are otherwise overwhelmingly expensive. It doesn't seem likely that such a complex, high pressure gasifier will be built at reasonable cost in the near future. The report recommends that Amoco not support further efforts to adapt the technology to make high pressure hydrogen.

Before we wind up this effort, I would like to have you review the report and let me know if there are areas where you have problems with our assumptions or calculations. Amoco is willing to evaluate any reasonable alternatives, and would welcome additional MTCI input on design or costs. We would also be willing to come out to Santa $\mathrm{Fe}$ Springs to discuss the results when you feel that would be useful.

Dural, I realize MTCI won't be very happy about the conclusions; we were also disappointed because we thought the concept had merit, too. But I think Joe Fox did a realistic evaluation, based on the input he's gotten from your staff, and the studies Bechtel did for Amoco on the Texaco 
Dr. K. Dura1-Swami

Page 2

gasifier. Please don't hesitate to call either Joe or me if you see ways we can configure the system or design around the problem areas. I want to be sure you're satisfied that we've done the best we can.

Best regards,

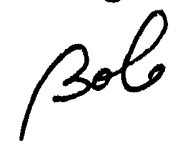

R. E. Lumpkin

REL

DRAFT 20210268 


\section{Comparison of MTCI's Indirect-Heated Coal Gasifier \\ with Texaco's Gasifier \\ for High-Pressure Hydrogen Production}

Prepared for:

Amoco Corporation

Alternative Fuels Development

By:

J. D. Fox

Amoco 011 Company

Research and Development Department

Naperville, Illinois

January 8,1992 


\section{Comparison of MTCI's Indirect-Heated Coal Gastfier with Texaco's Gasifier \\ for High-Pressure Hydrogen Production}

\section{Introduction}

Amoco Corporation has been assisting MTCI's Department of Energy funded effort to conduct research toward production of low-cost hydrogen by gasification of coal, coal char, and coal liquefaction residues in an indirectly-heated fluidized bed gasifier.

MTCI has claimed substantial economic benefits, up to $60 \%$ reduction in hydrogen production costs, by elimination of the oxygen plant required in Texaco's design. If true, this. would significantly lower the cost of coal liquefaction. This study attempts to compare the two gasifier processes on an equal basis, for production of high-pressure hydrogen for a coal liquefaction plant.

\section{Conceptual Process for MTCI's Gasifier}

MTCI's gasifier is a rectangular cross-section, low-pressure fluidized-bed vesse1, heated by internal firetubes featuring pulse combustion. This design is belleved to be inherently low-pressure because of tube-tovessel-wall seal limitations for the many firetubes required.

Pulse combustion enhances heat transfer by improving inside tubewall heat transfer coefficients, but strength considerations iimit tubewall temperatures to less than about 1,700 F. Solid coal and steam feed into a fluidized limestone or sand bed, and crude gas exits at about 1,300 $F$ and 5 psig into a cyclone separator and heat exchangers.

Figure 1 shows the conceptual process on which this study is based. Ground coal and ash concentrate from a liquefaction plant are fed to the gasifier, along with superheated steam, and bed-makeup material. Ground coal fue is the firetube heaters. Unconverted coal from the gasifier and combustor, ash, bed fines, and combustor flue gases are burned in a fluidized bed combustor which generates the steam required for the process. An optional turbogenerator, not shown, recovers power from pressure letdown of steam for the gasifier.

Because the MTCI gasifier operates at low pressure (5 psig assumed here), it is necessary to compress the crude gas stream to facilitate downstream processing. A key assumption here is that the crude gas stream must be compressed to 900 psig before it enters the shift reactor, the same pressure as in the Texaco process. This allows the specification of similar sizes and types of equipment downstream of the shift unit for both processes.

\section{Texaco Gasifier Process}

Figure 2 shows a block flow diagram for a typical Texaco coal gasification process. Texaco's gasifier is a relatively simple, refractory-lined, jacketed pressure vessel heated by in-situ partial combustion of coal in oxygen. Pumps feed a $60 \mathrm{wt}$. * coal-water slurry via preheaters and specially designed injection nozzles into the 2,500 to $2,700 \mathrm{~F}$ reaction 
zone. Molten slag flows down the walls of the entrained-flow gasifier vessel and exits at the bottom, while high-pressure crude gas leaves at the top, cooled by direct water quench and steam generators. Texaco gasifiers may operate at pressures up to 1,500 psig.

\section{Procedure}

Both gasifiers were sized to supply 1,200 tons/day of high-pressure hydrogen. This rate matchs that of an Amoco coal liquefaction study for which capital and energy requirements were available for a Texaco gasifier feeding ash concentrate and subbituminous coal. MTCI's recent experimental results were used to prepare a material balance for the conceptual process by adjusting for differences in flowrate, composition, etc. This provided input for ASPEN runs used to formulate energy balances necessary for the comparison.

MTCI supplied the gasifier cost, based on a recent quote for a char gasifier. This was escalated to the required capacity by MTCI's method. costs for the fluidized bed combustor (FBC) and turbogenerator equipment options studied for the MTCI process were furnished by Bechtel for an unrelated job. Amoco estimated the capital and operating costs of the large crude gas compressor.

A study of low-pressure shift and acid gas removal is beyond the scope of this analysis. However, the study of improved yield eliminating $c O$. production in the gasifier examines this indirectly by minimizing compression requirements and the size of the high-pressure shift and acid gas removal units. Low-pressure units imply much larger diameters which may be more costly than a larger crude gas compressor.

\section{Results}

Tables I through $V$ show typical case study results for the MTCI gasifier equipped with a fluidized bed combustor and turbogenerator. This level of detail is not shown for the other cases studied; only the comparisons on costs of production, Table $V$, is shown for the other cases studied. Table VI compares costs of production with Texaco's. All costs are shown in mid-1986 dollars, consistent with Amoco's other in-house coal studies.

A material balance was formulated using MTCI's latest information, i.e., "modified analyses" results from ash concentrate and subbituminous coal runs in their gasifier pilot plant. "A spreadsheet was constructed to "force" the overall and elemental material balances, and to integrate these results into the energy balances for economic analyses. A material balance for Texaco is not shown because the equipment and flows downstream of the shift reactor are similar, and the product hydrogen rate the same as the MTCI cases.

Tables I and II show the basis information and resulting material balance for the conceptual gasifier design. Streams 19 through 23 are not reported because these rates and compositions are the same as Texaco in all cases. Table II-A shows the factors used to force the balances, and the resulting overall and elemental balances. A coal liquefaction study provided the basis for shift reactor steam requirements."?

Table III compares the energy balances for the two processes. ASPEN simulations provided the compressor power requirements for MTCI's crude 
gas stream. ASPEN also allowed structuring of the MTCI energy balances to yield the same net steam requirements as Texaco, while recovering power from let-down steam in specific cases. Cooling requirements, deemed relatively inexpensive, were not increased in the cases with no power recovery.

Table IV compares the capital requirements for the Texaco and MTCI processes. No reference is cited for the Texaco costs shown because these are based on several Amoco in-house estimates. The Texaco costs were adjusted as noted in the "Comments" column of the table to yield capital requirements shown in column two for the conceptual MTCI process.

Table $V$ compares MTCI costs of production results with Texaco for the MTCI process option shown at the top of the table. Certain costs were ignored, e.g. operating labor and maintenance; these are likely higher for MTCI's more complex process.

Table VI summarizes the comparisons of Texaco's hydrogen production costs with MTCI's for all of the process options and sensitivities studied.

Discussion of Results

Texaco must use more costly dried coal to limit water fed to the gasifier. This, incidently, lowers Texaco's grinding costs. Dried coal for MTCI could not be justified by lower grinding costs alone, and here increased coal moisture serves to decrease gasifier steam requirements.

Variable costs for electric power increase when the turbogenerator is eliminated, but because the power unit-cost is low relative to capital charges, the turbogenerator option is not preferred unless power cost exceeds 5.8 cents $/ \mathrm{kW}$.

A comparison of power requirements (Table III) and capital costs (Table IV) shows that power costs for MTCI's crude syngas compressor exceed those for Texaco's oxygen plant, and MTCI's gasifier cost is more than five times that of Texaco.

In those cases where the FBC is eliminated, $\$ 2 / M S C F$ natural gas is purchased to fire a boiler. Here the gas boiler cost is assumed at $25 \%$ that of the FBC, and the char/ash disposed of at $\$ 100 /$ ton. Disposal cost would nearly double if stabilization to prevent organics and metals leaching were necessary. Table VI shows that a gas-fired boiler cannot be justified, even with $\$ 1 /$ MSCF gas and the disposal cost set to $\$ 1 /$ ton.

For the process options examined, hydrogen by MiCI's process costs 58 to 125 percent more than Texaco, using MTCI's adjusted experimental results. Even with the most optimistic yield improvement assumption of no $\mathrm{CO}_{3}$ made in the gasifier, MTCI's hydrogen cost remains about 30 percent higher than Texaco for the lowest-cost process option.

Thus, high-pressure hydrogen production by MTCI's conceptual process is not economically viable. MTCI needs to substantially decrease gasifier and crude gas compression costs to make this process competitive with Texaco. A high-pressure gasifier is needed, but this is inconsistent with lower cost for MTCI's complex, indirect-heated gasifier. 


\section{Conclusions}

1. High-pressure hydrogen production by this conceptual MTCI process is not economically viable.

2. Power requirements for MTCI's crude syngas compression exceed those of Texaco's oxygen plant. Also, the gasifier costs five times that of Texaco, and MTCI's coal preparation costs are higher.

3. For the process options examined, hydrogen by MTCI's process costs 58 to 125 percent more than Texaco, based on MTCI's experimental results.

4. Even with the most oftimistic yield improvement assumption (no $\mathrm{CO}$, made in the gasifier), MTCI's hydrogen cost remains about 30 percent higher than Texaco, for the lowest-cost process option.

5. The turbogenerator option is preferred if purchased power exceeds 5.8 cents/kw. However, a gas-fired boller cannot be justifled; costs remain higher here even with $\$ 1 /$ ton char disposal fee and $\$ 1 /$ MSCF natural gas.

\section{Recommendations}

MTCI's must develop a low cost, high-pressure gasifier for tts process to be competitive with Texaco's. Amoco support in this effort should be discontinued, because it is highly unlikely that such a gasifier can be bullt at a reasonably low cost. 


\section{REFERENCES}

1. Ashok K. Das's (MTCI) letter of August 27, 1991 to J. D. Fox.

2. Draft Report, "Conceptual Design of Commercial Two Stage Coal Liquefaction Facility", under DOE Contract NO. DEACO1-78ET10159, prepared by UOP/SDC Joint Venture, November, 1980. 
COAL GASIFICATION--SENSITIVITIES ON COSIS OF PRODUCTION

Process Description 11
Costs of Production. S/MSCE (1986)

operating Capital Iotal Diff.

0.7

0.9

1.56

Base

Texaco Gasifier:

MTCI Gasifier Options:

FBC and Turbogenerator

0.8

1.8

2.65

$+1.09$

w/ $0.058 \$ / \mathrm{kw}$ Power

1.1

1.8

2.89

$+1.33$

FBC W/O Turbogenerator

$w / 0.058 \$ / \mathrm{kw}$ Power

0.9

1.6

2.46

$+0.90$

1.3

1.6

2.89

$+1.33$

FBC and Turbogenerator, No $\mathrm{CO}_{2}$ made in gasifier

0.7

0.7

1.5

2.18

$+1.62$

FBC W/O Turbogenerator, NO $\mathrm{CO}_{\text {? }}$ made in gasifier

0.7

1.3

2.02

$+0.46$

Gas-Fired Boiler w/o

2.0

1.6

3.51

$+1.95$

Turbogenerator

w/ $\$ 1 /$ ton Char Disposa1, $\$ 1 /$ MSCF Nat. Gas

1.0

1.6

2.60

$+1.04$

$$
1.6
$$

2.60

\section{(1) Key:}

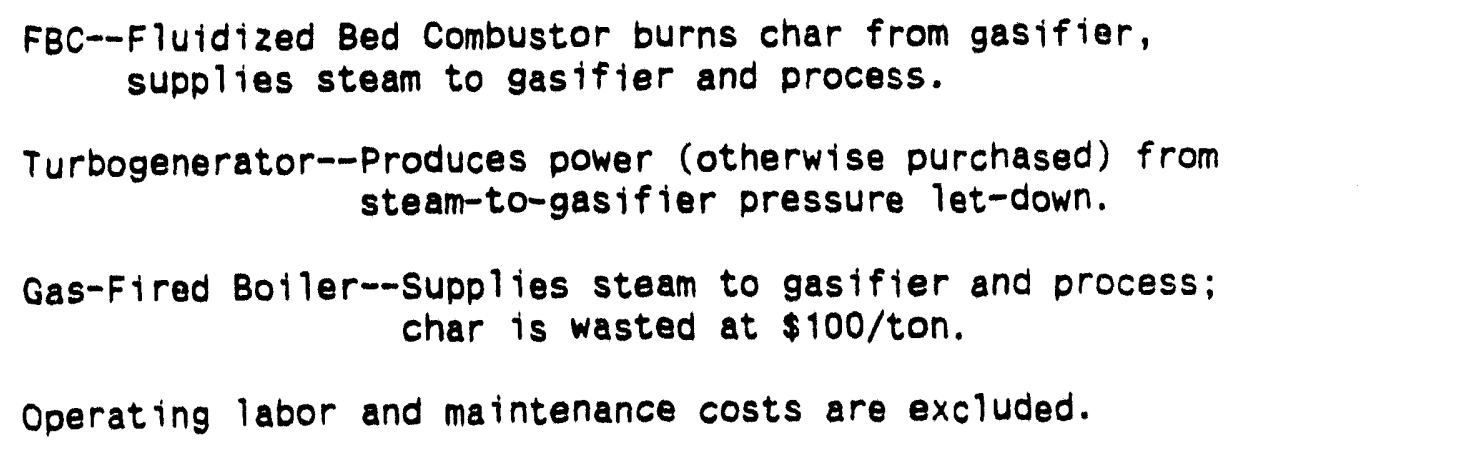




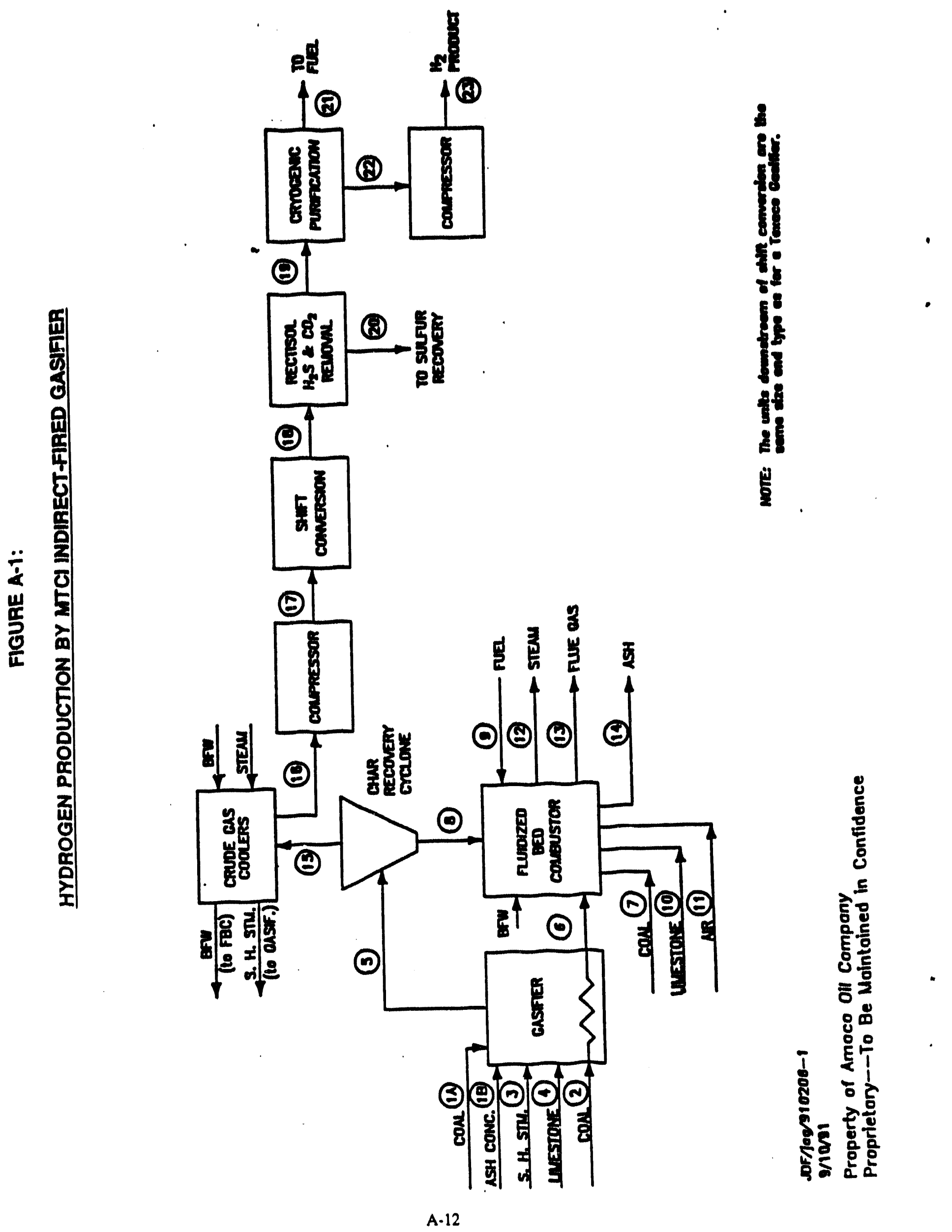




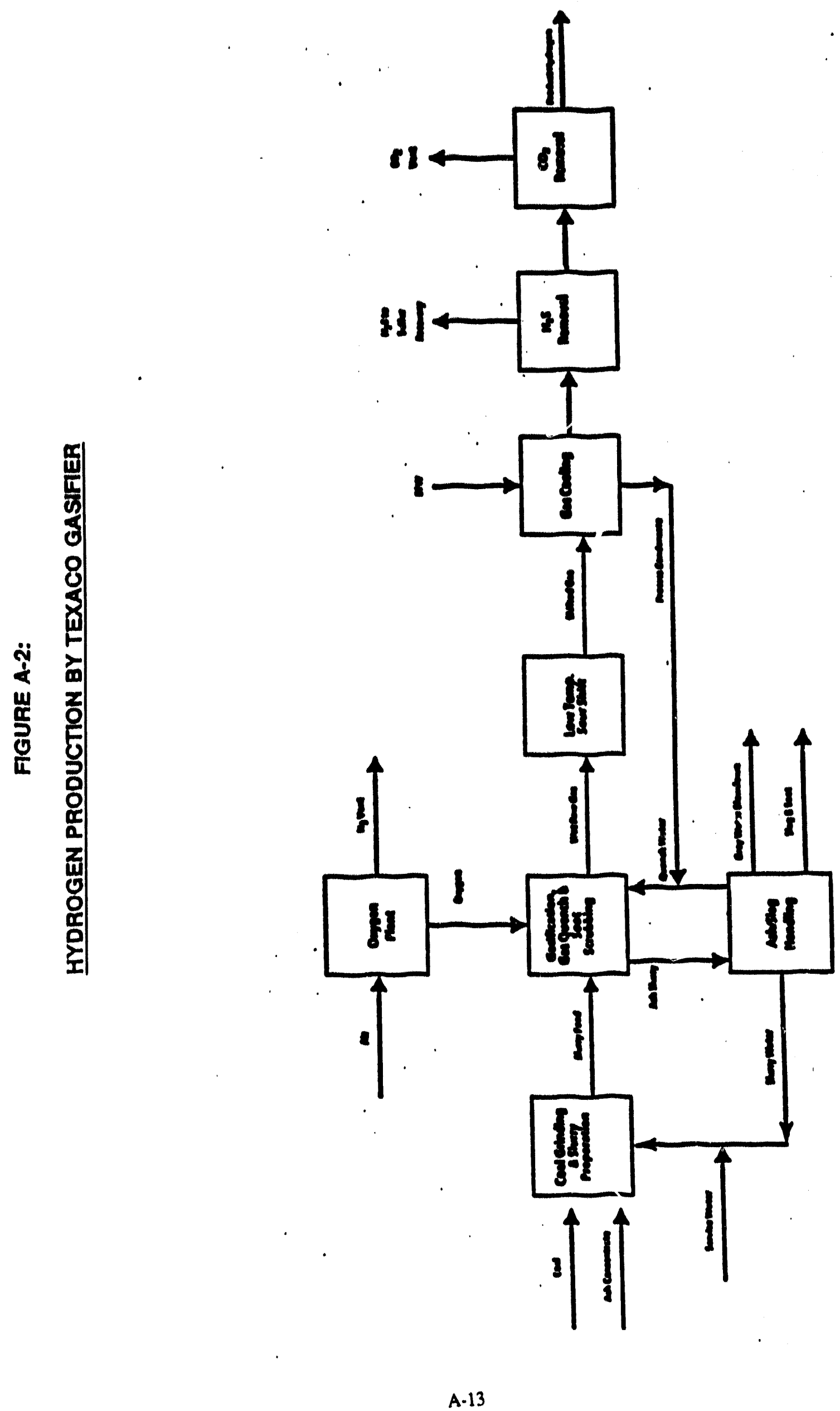




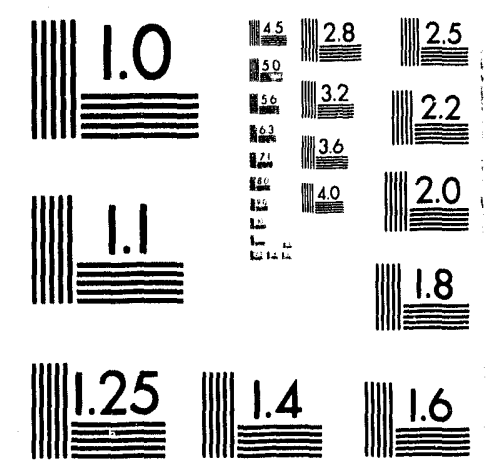




\section{TABEI}

FBC W/TURBOCENERATOR

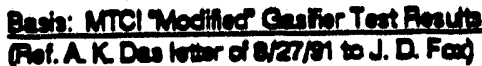

MTret Tabio No.:

Fead:

Foed Rutio, tome en rected.

Sbam Rats, b/r

Prod. Con Plet, bom

Food:

Pred en Componart:

m

$\infty$

$\infty$

cr

con:

can

$\infty$

ca

HeS

NoB

Toul:

\begin{tabular}{|c|c|c|c|c|}
\hline \multirow{4}{*}{$\begin{array}{l}12 \\
\infty\end{array}$} & \multicolumn{3}{|c|}{ 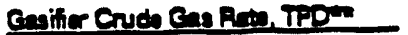 } & \multirow{5}{*}{$\begin{array}{r}1,2=0.72 \\
Q<0 \\
0 \leq 0\end{array}$} \\
\hline & An Cons. & Geed & Iot? & \\
\hline & $\Xi$ & $\mathbf{7 3 1}$ & $\operatorname{Er}$ & \\
\hline & 1,791 & 2,201 & 3503 & \\
\hline $\cos$ & $\infty$ & 8,134 & $2,8=0$ & \\
\hline c1 & 124 & 327 & 451 & \\
\hline 2 & 16 & $\infty$ & 105 & \\
\hline $\mathbf{c}$ & 24 & 14 & 30 & \\
\hline$\overline{c 4}$ & 15 & 18 & 30 & \\
\hline Hes & 12 & $\boldsymbol{3 1}$ & $\$$ & \\
\hline$N+\mathbf{B}$ & s0 & 2 & $\leqslant 0$ & \\
\hline & $2, \overline{57}$ & 11574 & 14,311 & \\
\hline
\end{tabular}

\section{Cenifier Becis:}

Feed, TPD, es rectel:

Fud, TPD, es rected."

29

1,011

$$
8,000 \quad 11,016
$$$$
4,750 \quad 5,750
$$

Lieuctegion Plant Besie:

Food, TPD MWF

HeDomand, \% of MWF Foed

mol s formilined

1220

$2 x$

213

Q⿻3

Q16

0.06

Q.04

0.14

Q.00

$100.001,310.41$

5,140

7.018

\section{CONL EASIFICATION-MIERLL BN NACE} FOA CONCEPTUAL MTCI PROCESS

Ah Cone. Subt Cod Ah Cons. Subt Cod Ash Cone. Subt Conl

mol bin

112.00

3428

$1,267.60$

6021

20

421

200

23

4.77

0.09

1,71530

berelib foed (anoted)t

0.870 .270

$0.17 \quad 1.00$

a.d a.0.

a.r 201

an 200

0,000

$0, \quad 0 . \infty$

0.010 .00

$0.00 \quad 0.00$

an $\quad 1.40$

-Adiend to $05 \%$

"castieation offieiency.

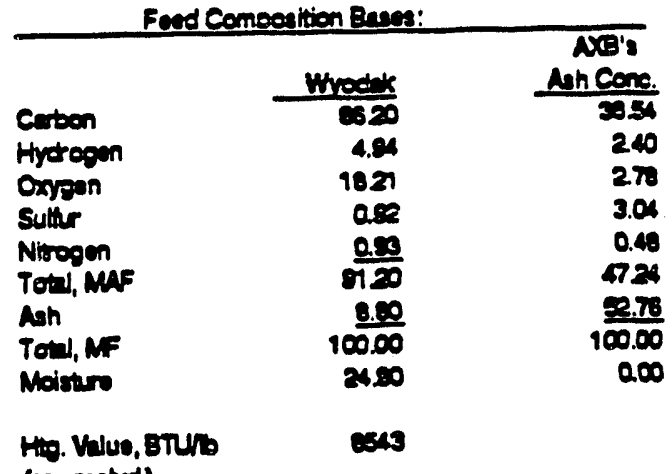

(as-reved.

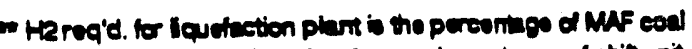
aid shown, plus s\%s for mice. bases downatrean of shits unit

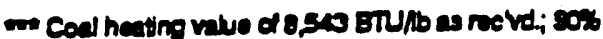

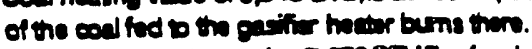

casifier eneroy demands: 7,872 BTU6 of earben gasilled

1,000 BTuhb of moists

415 Bnub of ash + U.c. carben 


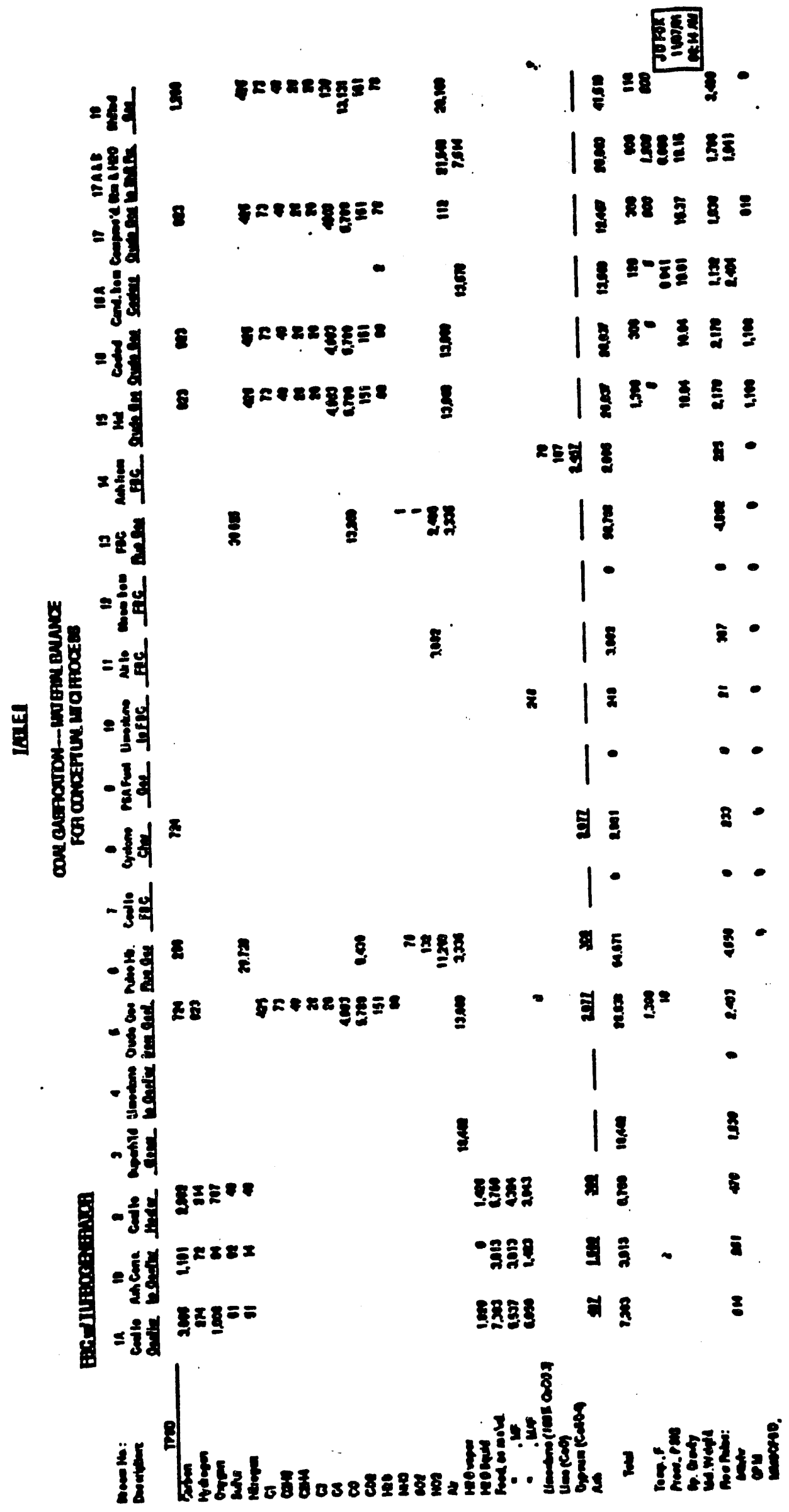


TABLE U-A

CONL GASIFICATION-DMTERIL BALANCE

FOR CONCEPTUN MTCI PROCESS

\section{FBC W/TURBOGENERATOR}

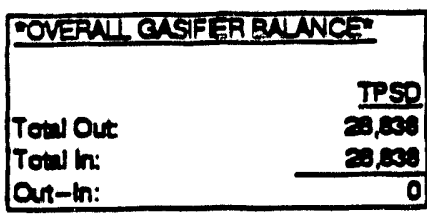

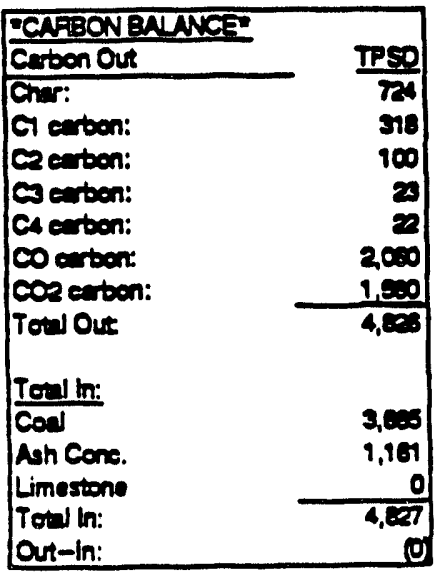

\section{OXYCEN BNLANCE:}

oxyoen ar:

oxyoen

$\infty$

$\infty$

HeO nep.tlia.

CeO

Toul Out

Oxmanin

oxyen

HeO vap

Heolia

cucos

Toul in:

Out-ln:

\begin{tabular}{|c|c|}
\hline \\
\hline \multicolumn{2}{|c|}{ FFOEOCDN BNUNCF } \\
\hline \multirow{9}{*}{ 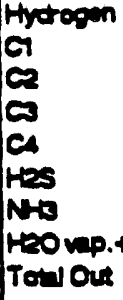 } & 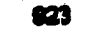 \\
\hline & 107 \\
\hline & 22 \\
\hline & 5 \\
\hline & 8 \\
\hline & $\theta$ \\
\hline & 14 \\
\hline & 1,520 \\
\hline & 2,618 \\
\hline \multirow{5}{*}{ 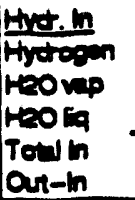 } & \\
\hline & 346 \\
\hline & 2,000 \\
\hline & $\frac{20}{2,010}$ \\
\hline & 0 \\
\hline
\end{tabular}
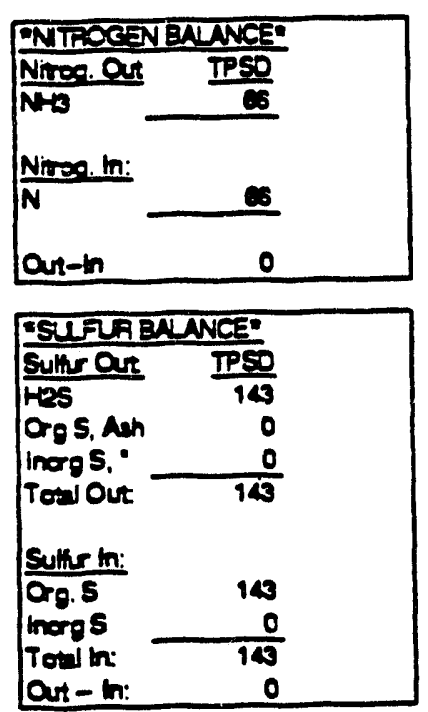

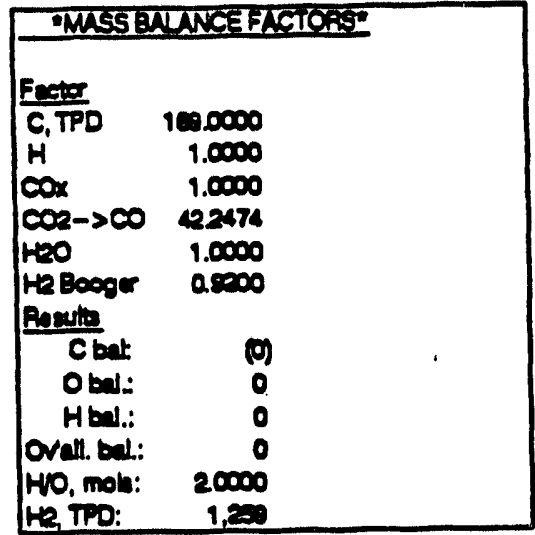

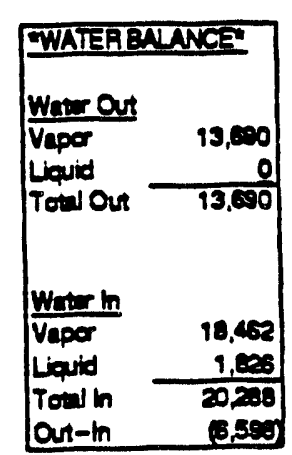

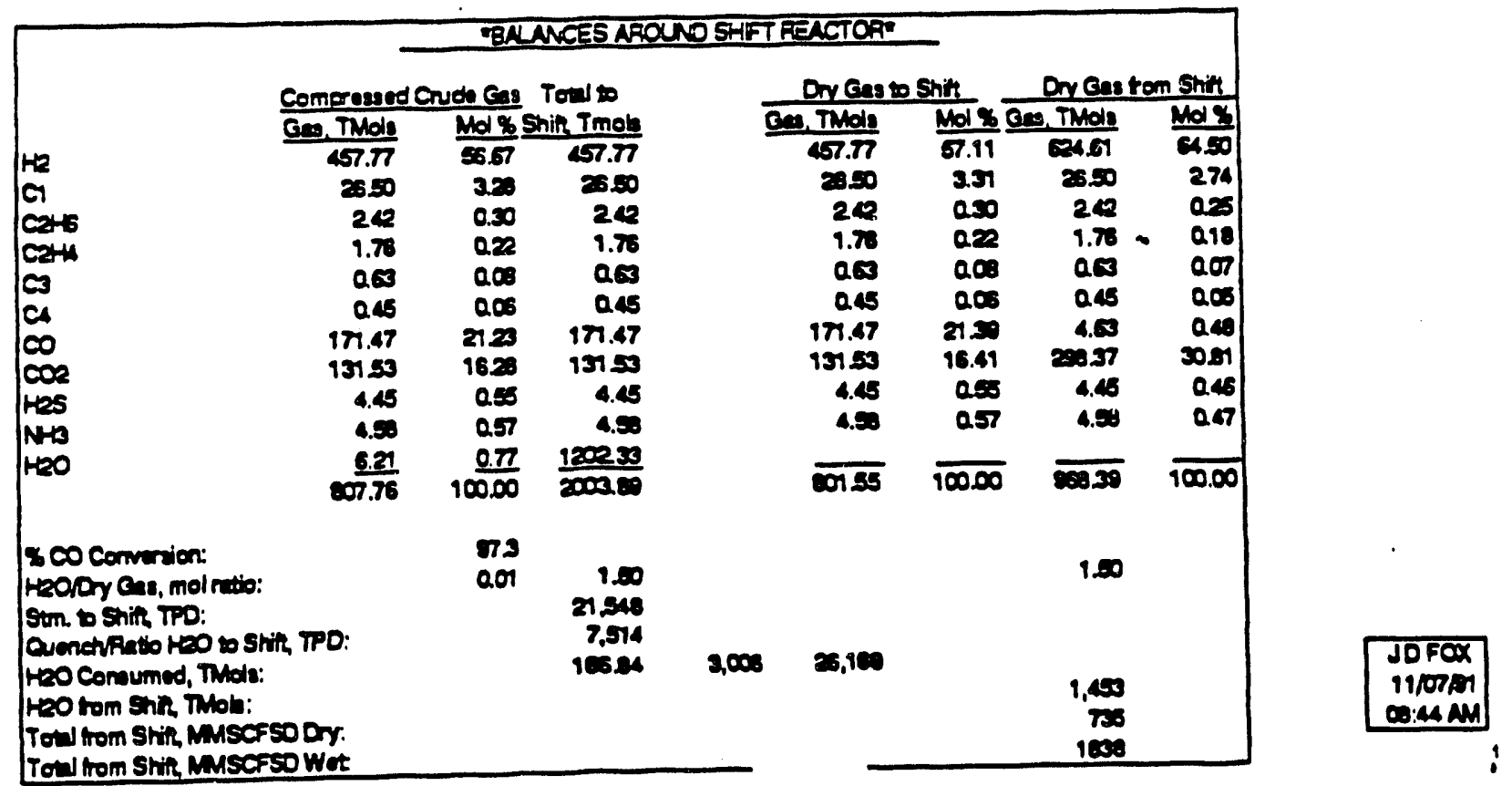




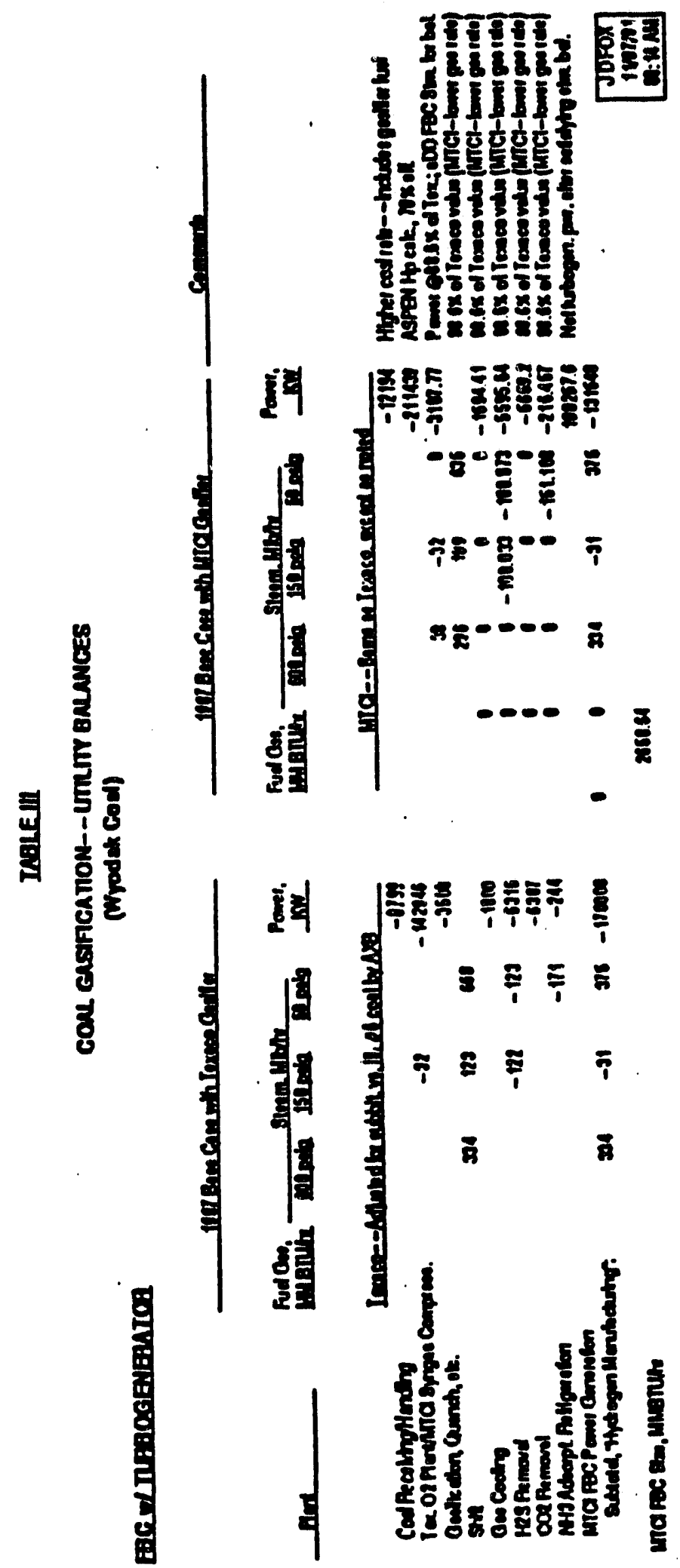


COAL GASIFICATION-CAPITAL REQUIREMENTS FOR

FOR TEXACO AND MTCI PROCESSES

\section{FBCW/TURBOGENERATOR}

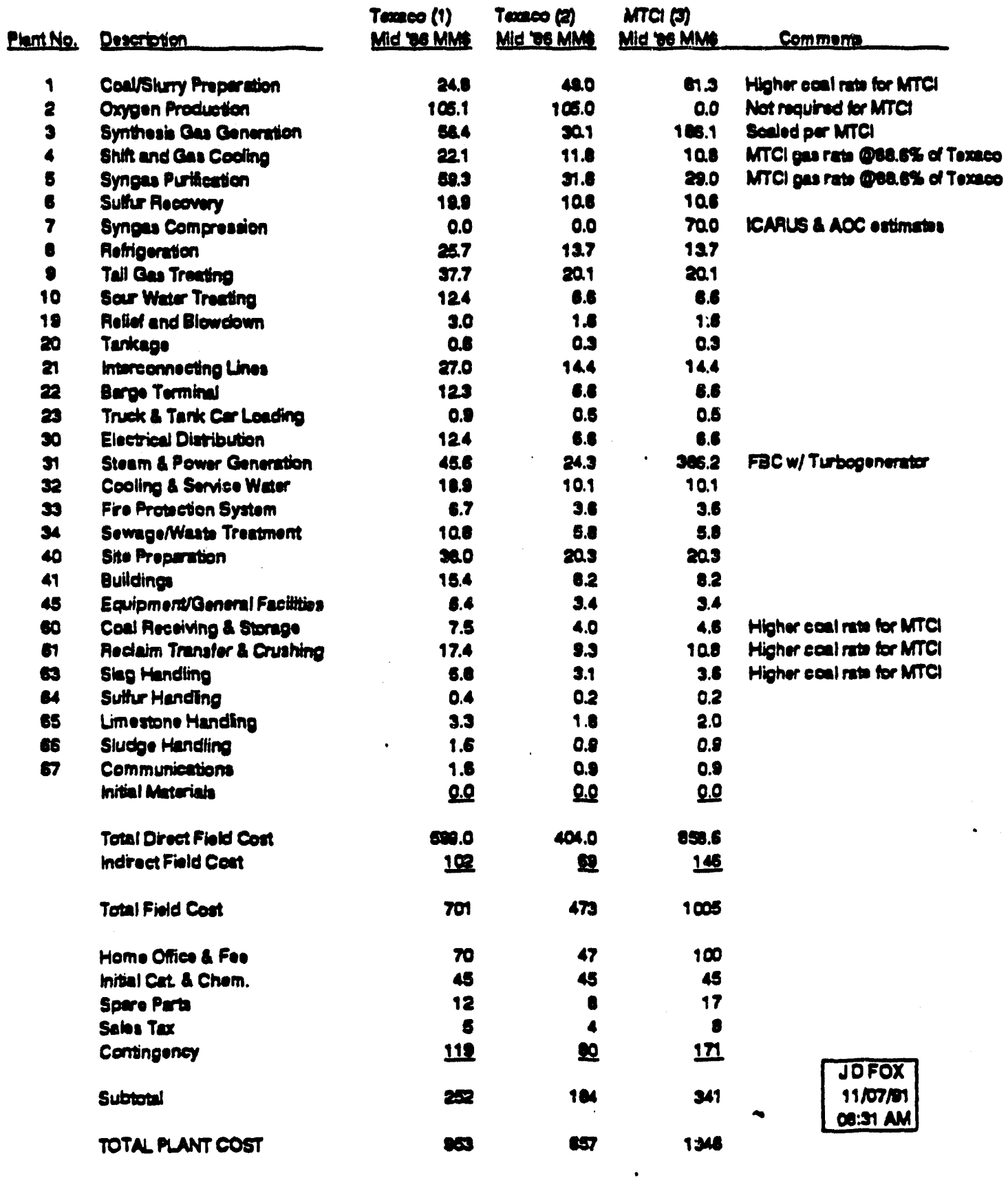




\section{TABLEV}

COAL GASIFICATION--COMPARUSONS ON COSTS OF PRODUCTION

(Wyodak Coal; 1936 MMNY)

FBCW/TUABOGENERATOR

\begin{tabular}{|c|c|c|c|}
\hline Variable Operating Costs & $\begin{array}{l}\text { O7 Bese Case W/ } \\
\text { Texaco Gestier }\end{array}$ & $\begin{array}{l}\text { B7 Bese Cese W/ } \\
\text { MTCl Geslier }\end{array}$ & \\
\hline $\begin{array}{l}\text { MF COal, MTSD: } \\
\text { To Gastication } \\
\text { To Fuel \& Power Generation }\end{array}$ & $\begin{array}{l}8.0 \\
0.0\end{array}$ & $\begin{array}{l}9.9 \\
0.0\end{array}$ & \\
\hline Cost (\$72/ Texaco, \$7T MTC) & 33.2 & 28.7 & . \\
\hline $\begin{array}{l}\text { Natural Gas, MMSCFD: } \\
\text { For HL Manufacture }\end{array}$ & 0.0 & 0.0 & \\
\hline Cost (@ S2MSCF) & 0.0 & 0.0 & \\
\hline Eectrictly (@ \$0.02385/KM) & 30.5 & 23.8 & \\
\hline $\begin{array}{l}\text { Catalysts \& Chemicals: } \\
\text { Limestone (@ \$7Ton) } \\
\text { Pyite, Cat \& Chem. } \\
\text { Waste Disposal (@ soorton) }\end{array}$ & $\begin{array}{l}0.0 \\
0.0\end{array}$ & $\begin{array}{l}0.6 \\
0.0 \\
0.0\end{array}$ & \\
\hline $\begin{array}{l}\text { Operating Supplies } \\
\text { Rolling Stock }\end{array}$ & $\begin{array}{l}0.0 \\
0.0\end{array}$ & $\begin{array}{l}0.0 \\
0.0\end{array}$ & \\
\hline $\begin{array}{l}\text { SUBTOTAL } \\
\text { SUBTOTAL (x-COE \& GAS) }\end{array}$ & $\begin{array}{l}63.7 \\
30.5\end{array}$ & $\begin{array}{l}52.9 \\
24.2\end{array}$ & \\
\hline \multicolumn{4}{|l|}{ Fixed Costs } \\
\hline $\begin{array}{l}\% \text { of Total Plant costs } \\
\text { Fixed Costs, MMSily (1 886) }\end{array}$ & $\begin{array}{l}4.78 \\
31.5 \\
\end{array}$ & $\begin{array}{l}4.79 \\
64.5 \\
\end{array}$ & \\
\hline TOTAL & 95.2 & 117.4 & \\
\hline \multicolumn{4}{|l|}{ COST OF PRODUCTION, 'BESMMSF } \\
\hline $\begin{array}{l}\text { Operating Costs } \\
\text { Capital Cost (@19.1 K/y) }\end{array}$ & $\begin{array}{l}0.7 \\
0.9 \\
\end{array}$ & $\begin{array}{l}0.8 \\
1.8 \\
1\end{array}$ & \\
\hline $\begin{array}{l}\text { TOTAL } \\
\text { PRODUCTION, MINISCF/C.YR }\end{array}$ & $\begin{array}{r}156 \\
1412\end{array}$ & 265 & $\begin{array}{l}\text { JDFOX } \\
11 / 07 / 81 \\
0014 A M\end{array}$ \\
\hline
\end{tabular}




\section{TABIE V}

CONL GASIFICATION--COMPAPISONS ON COSTS OF PRODUCTION (Wyodak Coal; 1986 MMAs)

FBCW/TURBOGENERATOR

\begin{tabular}{|c|c|c|}
\hline Variable Operating costs & $\begin{array}{l}\text { '87 Base Case W/ } \\
\text { Texaco Caslier }\end{array}$ & $\begin{array}{l}\text { 87 Base Case W/ } \\
\text { MTCl Gasller }\end{array}$ \\
\hline $\begin{array}{l}\text { MF COA, MTSD: } \\
\text { To Gastication } \\
\text { To Fuel \& Power Generation }\end{array}$ & $\begin{array}{l}8.0 \\
0.0\end{array}$ & $\begin{array}{l}8.9 \\
0.0\end{array}$ \\
\hline $\operatorname{Cost}(\$ 12 \pi T$ Texaco, $\$ 7 \pi \mathrm{MTCl})$ & 33.2 & 28.7 \\
\hline $\begin{array}{c}\text { Natural Gas, NivSCFD: } \\
\text { For H2 Manutacture }\end{array}$ & 0.0 & 0.0 \\
\hline Cost (@ \$2MSCF) & 0.0 & 0.0 \\
\hline Electricity (@so058km) & 74.1 & 57.3 \\
\hline $\begin{array}{l}\text { Catalysts \& Chemicals: } \\
\text { Limestone (@ \$7/Ton) } \\
\text { Pyrite, Cat. \& Chem. } \\
\text { Waste Disposal (@ s100/Ton) }\end{array}$ & $\begin{array}{l}0.0 \\
0.0\end{array}$ & $\begin{array}{l}0.6 \\
0.0 \\
0.0\end{array}$ \\
\hline $\begin{array}{l}\text { Operating Supplies } \\
\text { Rolling Stock }\end{array}$ & $\begin{array}{l}0.0 \\
4.0\end{array}$ & $\begin{array}{l}0.0 \\
0.0\end{array}$ \\
\hline $\begin{array}{l}\text { SUBTOTAL } \\
\text { SUBTOTAL ( } x \text { - COal \& Gas) }\end{array}$ & $\begin{array}{r}107.3 \\
74.1\end{array}$ & $\begin{array}{l}86.7 \\
57.8\end{array}$ \\
\hline
\end{tabular}

Fixed Costs

$\begin{array}{lrr}\text { \% of Total Plant Costs } & 4.79 & 4.79 \\ \text { Fixed Costs, MMSiry (1886) } & 31.5 & 64.5 \\ & & 151.1\end{array}$

COST OF PRODUCTION, 'BSSMSCF

$\begin{array}{lrr}\text { Operating Costs } & 1.0 & 1.1 \\ \text { Capital Cost (@19.1 } / / y) & 0.9 & 1.8 \\ \text { TOTAL } & 1.87 & 2.89 \\ \text { PRODUCTION, MMMSCF/C.YR } & 1412 & 1412\end{array}$




\section{TABLEV}

CON GASIFICATION--COMPAPUSONS ON COSTS OF PRODUCTION (Mrodak Coal; 1986 MML)

FBC W/O TURBOGENERATOR

\begin{tabular}{|c|c|c|c|}
\hline Variable Opereting Costs & $\begin{array}{l}\text { D7 Bese Case W/ } \\
\text { Texaco Gearlier }\end{array}$ & $\begin{array}{l}\text { 97 Base Case W/ } \\
\text { MTCI Costive }\end{array}$ & \\
\hline $\begin{array}{l}\text { MF Cod, MTSD: } \\
\text { To Gastication } \\
\text { To Fuel \& Power Generation }\end{array}$ & $\begin{array}{l}8.0 \\
0.0\end{array}$ & $\begin{array}{l}8.0 \\
0.0\end{array}$ & - \\
\hline Cost (\$12/ Texaco, $57 \pi$ MTCD) & 232 & 28.7 & \\
\hline $\begin{array}{l}\text { Natural Gas, Misc CFD: } \\
\text { For HE Manufacture }\end{array}$ & 0.0 & 0.0 & \\
\hline $\operatorname{cost}(@$ \$2MSCr) & 0.0 & 0.0 & \\
\hline Electrictly (@ $\$ 0.02385 \mathrm{Km}$ ) & 30.5 & 43.0 & \\
\hline $\begin{array}{l}\text { Catalysts \& Chemieals: } \\
\text { Limestone (@ S7/Ton) } \\
\text { Pyitt, Cat \& Chem. } \\
\text { Waste Disposa (@ S corton) }\end{array}$ & $\begin{array}{l}0.0 \\
0.0\end{array}$ & $\begin{array}{l}0.8 \\
0.0 \\
0.0\end{array}$ & \\
\hline $\begin{array}{l}\text { Operating Supplies } \\
\text { Rolling Stock }\end{array}$ & $\begin{array}{l}0.0 \\
0.0\end{array}$ & $\begin{array}{l}0.0 \\
0.0\end{array}$ & \\
\hline $\begin{array}{l}\text { SUBTOTAL } \\
\text { SUBTOTNL }(x-\operatorname{COA} \& \text { GES) }\end{array}$ & $\begin{array}{l}69.7 \\
30.5\end{array}$ & $\begin{array}{l}72.3 \\
43.6\end{array}$ & \\
\hline \multicolumn{4}{|l|}{ Fixed costs } \\
\hline $\begin{array}{l}x \text { \& Total Plant Costs } \\
\text { Fbxed Costs, MMShy (1886) }\end{array}$ & $\begin{array}{l}4.79 \\
31.5\end{array}$ & $\begin{array}{l}4.79 \\
55.1 \\
\end{array}$ & \\
\hline TOTAL & 85.2 & 127.4 & \\
\hline \multicolumn{4}{|l|}{ COST OF PRODUCTION, 'BSSMNSCF } \\
\hline $\begin{array}{l}\text { Operating Costs } \\
\text { Copltal Cost (@18.1 X/y) }\end{array}$ & $\begin{array}{l}0.7 \\
0.9\end{array}$ & $\begin{array}{l}0.8 \\
1.6 \\
\end{array}$ & \\
\hline TOTAL & 158 & 2.46 & $\begin{array}{l}\text { JOFOX } \\
11 / 07 / 91\end{array}$ \\
\hline PRODUCTION, MMMSCF/C.YR & 1412 & 1412 & $08: 54$ M \\
\hline
\end{tabular}




\section{TABLEV}

CONL GASIFICATION--COMPARISONS ON COSTS OF PRODUCTION (Wyodak Coal; 1836 MMS)

FBC W/O TURBOGENERATOR

\begin{tabular}{|c|c|c|}
\hline Variable Operetina Costs & $\begin{array}{l}\text { se Case w/ } \\
\text { o Gosilier }\end{array}$ & $\begin{array}{l}\text { B7 Base Case W/ } \\
\text { MTCI Gestior }\end{array}$ \\
\hline $\begin{array}{l}\text { MF Cod, MTSD: } \\
\text { To Gaslication } \\
\text { To Fuol \& Power Generation }\end{array}$ & $\begin{array}{l}8.0 \\
0.0\end{array}$ & $\begin{array}{l}9.9 \\
0.0\end{array}$ \\
\hline $\operatorname{Cost}(512 \pi T$ Texaco, $57 \pi \mathrm{MTCD})$ & 33.2 & 28.7 \\
\hline $\begin{array}{l}\text { Natural Gas, MiNSCFD: } \\
\text { For HQ Manulacture }\end{array}$ & 0.0 & 0.0 \\
\hline Cost (@\$2MSCF) & 0.0 & 0.0 \\
\hline Electricity (@.0.058/km) & 74.1 & 104.5 \\
\hline $\begin{array}{l}\text { Catalysts \& Chemicals: } \\
\text { Limestone (@ \$7/Ton) } \\
\text { Pyite, Cat \& Chem. } \\
\text { Waste Disposal (@ s1 Do/Ton) }\end{array}$ & $\begin{array}{l}0.0 \\
0.0\end{array}$ & $\begin{array}{l}0.6 \\
0.0 \\
0.0\end{array}$ \\
\hline $\begin{array}{l}\text { Operating Supplies } \\
\text { Rolling Stock }\end{array}$ & $\begin{array}{l}0.0 \\
0.0\end{array}$ & $\begin{array}{l}0.0 \\
0.0\end{array}$ \\
\hline $\begin{array}{l}\text { SUBTOTAL } \\
\text { SUBTOTAL ( } x-\operatorname{COA} \& \text { Gas) }\end{array}$ & $\begin{array}{r}107.3 \\
74.1\end{array}$ & $\begin{array}{l}133.9 \\
105.1\end{array}$ \\
\hline \multicolumn{3}{|l|}{ Fixed Costs } \\
\hline $\begin{array}{l}\text { \% of Total Plant Costs } \\
\text { Fixed Costs, MMS/Yr (1 886) }\end{array}$ & $\begin{array}{l}4.79 \\
31.5 \\
\end{array}$ & $\begin{array}{l}4.78 \\
55.1 \\
\end{array}$ \\
\hline TOTAL & 138.8 & 189.0 \\
\hline \multicolumn{3}{|c|}{ COST OF PROOUCTION, '86SMASCF } \\
\hline $\begin{array}{l}\text { Operating Costs } \\
\text { Capital Cost (@ } 19.1 \% / y \text { ) }\end{array}$ & $\begin{array}{l}1.0 \\
0.9 \\
\end{array}$ & $\begin{array}{l}1.3 \\
1.6 \\
\end{array}$ \\
\hline TOTAL & 1.87 & 2.89 \\
\hline PRODUCTION, MIMUSCFIC.YR & 1412 & 1412 \\
\hline
\end{tabular}




\section{TABLEV}

CONL GASIFICATION--COMPARISONS ON COSTS OF PRODUCTION

(Myodak Coal; 1986 Mnis)

NOQASIFIER COF, FBCW/TURBOGENERATOR

\begin{tabular}{|c|c|c|c|}
\hline Veriable Operating Costs & $\begin{array}{l}\text { D7 Bewe Case W/ } \\
\text { Texaco Gestier }\end{array}$ & $\begin{array}{l}\text { "B7 Bese Cese WI } \\
\text { MTCI Geslier }\end{array}$ & \\
\hline $\begin{array}{l}\text { MF Cod, MTSD: } \\
\text { To Gasliteation } \\
\text { To Fud \& Power Ceneration }\end{array}$ & $\begin{array}{l}8.0 \\
0.0\end{array}$ & $\begin{array}{l}6.6 \\
0.0\end{array}$ & \\
\hline $\operatorname{cost}(5 T 2 \pi$ Texeco, $57 \pi \mathrm{MTC})$ & 332 & 19.2 & . \\
\hline $\begin{array}{l}\text { Natural Gas, MusCFD: } \\
\text { For HE Manufacture }\end{array}$ & 0.0 & 0.0 & \\
\hline Cost (@ S2MSCF) & 0.0 & 0.0 & \\
\hline Eectrictty (@ $\$ 0.02385 / \mathrm{Km}$ ) & 30.5 & 18.3 & \\
\hline $\begin{array}{l}\text { Catalysts \& Chemicals: } \\
\text { Limestone (@ \$7/Ton) } \\
\text { Pyite, Cat \& Chem. } \\
\text { Waste Disposal (@ st Co/Ton) }\end{array}$ & $\begin{array}{l}0.0 \\
0.0\end{array}$ & $\begin{array}{l}0.4 \\
0.0 \\
0.0\end{array}$ & \\
\hline $\begin{array}{l}\text { Operating Supplies } \\
\text { Rolling Stock }\end{array}$ & $\begin{array}{l}0.0 \\
0.0\end{array}$ & $\begin{array}{l}0.0 \\
0.0\end{array}$ & \\
\hline $\begin{array}{l}\text { SUBTOTAL } \\
\text { SUBTOTAL ( } x-\operatorname{COA} \& \text { GaS) }\end{array}$ & $\begin{array}{l}63.7 \\
30.5\end{array}$ & $\begin{array}{l}38.8 \\
18.7\end{array}$ & \\
\hline Fixed Costs & & & $\cdot$ \\
\hline $\begin{array}{l}\text { \% of Total Plant Costs } \\
\text { Fixed Costs, MMSiny (1886) }\end{array}$ & $\begin{array}{l}4.79 \\
31.5 \\
\end{array}$ & $\begin{array}{r}4.79 \\
54.1 \\
\end{array}$ & \\
\hline TOTAL & 952 & 928 & \\
\hline \multicolumn{4}{|l|}{ COST OF PROOUCTION, 'EOSMSCF } \\
\hline $\begin{array}{l}\text { Operating Costs } \\
\text { Copital Cost (@18.1\%/y) }\end{array}$ & $\begin{array}{l}0.7 \\
0.9 \\
\end{array}$ & $\begin{array}{l}0.7 \\
1.5 \\
\end{array}$ & \\
\hline TOTAL & 1.58 & 2.18 & $\begin{array}{l}\text { JDFOX } \\
11 / 07 / 91\end{array}$ \\
\hline PRODUCTION, MNIMSCF/C.YR & 141.8 & 141.6 & $08: 35 \mathrm{AM}$ \\
\hline
\end{tabular}




\section{TABIFY}

CONL GASIFICATION--CONPARISONS ON COSTS OF PRODLCTION

(Myodak Coal; 1988 Mary

NO QASIFER COZ FBC WO TLABOCENERATOR

\begin{tabular}{|c|c|c|}
\hline Verleble Operenine Const & $\begin{array}{l}\text { Cose wl } \\
\text { ocming }\end{array}$ & 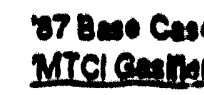 \\
\hline $\begin{array}{l}\text { MF Cod, MTSD: } \\
\text { To Gaslleation } \\
\text { To Fual \& Power Ceneration }\end{array}$ & $\begin{array}{l}8.0 \\
0.0\end{array}$ & $\begin{array}{l}0.8 \\
0.0\end{array}$ \\
\hline Cost (s1e/T Toxaco, $57 /$ MTC) & 382 & 102 \\
\hline $\begin{array}{l}\text { Natural Cas, Mis CFD: } \\
\text { For He Manutacture }\end{array}$ & 0.0 & 0.0 \\
\hline Coti (@ S2MSCF) & 0.0 & 0.0 \\
\hline Electrietly (@ s0.02385/Km) & 30.5 & 332 \\
\hline $\begin{array}{l}\text { Catalysta \& Chemicals: } \\
\text { Limestone (@ s7/Ton) } \\
\text { Pyitu, Cat \& Chem. } \\
\text { Waste Disposa (@ storton) }\end{array}$ & $\begin{array}{r}0.0 \\
.0 .0\end{array}$ & $\begin{array}{l}.9 \\
0.0 \\
0.0\end{array}$ \\
\hline $\begin{array}{l}\text { Operating supplies } \\
\text { Rolling Stock }\end{array}$ & $\begin{array}{l}0.0 \\
0.0\end{array}$ & $\begin{array}{l}0.0 \\
0.0\end{array}$ \\
\hline $\begin{array}{l}\text { SUBTOTAL } \\
\text { SUETOTAL ( } x-\operatorname{COA} \& \text { Ges) }\end{array}$ & $\begin{array}{l}63.7 \\
30.8\end{array}$ & $\begin{array}{l}82.7 \\
33.6\end{array}$ \\
\hline
\end{tabular}

\section{Fixed Costs}

$x$ of Total Plant Costs

Fixed Costs, MMSAy (1836)

91.8

4.79

TOTAL

95.2

46.7

COST OF PRODUCTION, 'BSEMSCF

Operating costs

Copltal Cost (@18.1 x/yn)

TOTAL

PRODUCTION, MMMSCF/C.YA

\section{0}

102

0.0

0.0

332

0.4

0.0

0.0

0.0

0.0

39.6

90.4

0.7

13

2.02

141.6 


\section{TABIEV}

CONL GASIFTCATION--CONPAPUSONS ON COSTS OF PRODUCTION (Myodak Coal; 1936 MMA)

QAS-FIFED BOILER W/O TURBOCENERATOR

\begin{tabular}{|c|c|c|c|}
\hline vercole ooerting coas & $\begin{array}{l}07 \text { Bene Case W/ } \\
\text { Texaco Castier }\end{array}$ & $\begin{array}{l}\text { "B7 Bese Cese W/ } \\
\text { MTCI Gastior }\end{array}$ & \\
\hline $\begin{array}{l}\text { MF Con, MTSO: } \\
\text { To Canleatton } \\
\text { To Fual \& Power Coneration }\end{array}$ & $\begin{array}{l}8.0 \\
0.0\end{array}$ & $\begin{array}{l}8.9 \\
0.0\end{array}$ & \\
\hline $\operatorname{cost}(B 12 \pi T$ Toxuco, $7 \pi \pi$ MTCD) & 332 & 28.7 & \\
\hline $\begin{array}{l}\text { Naturd Cas, MissCFD: } \\
\text { Por the Manulacture }\end{array}$ & 0.0 & 63.8 & \\
\hline $\operatorname{cost}(@ \operatorname{san} M S C F)$ & 0.0 & 40.0 & \\
\hline Eecticty (@ $\$ 0.02385 / \mathrm{km})$ & 30.5 & 43.0 & \\
\hline $\begin{array}{l}\text { Catalysts \& Chemicals: } \\
\text { Umestone (@ \$7/Ton) } \\
\text { Pyrte, Cat. Chem. } \\
\text { Westo Disposal (@ stoorton) }\end{array}$ & $\begin{array}{l}0.0 \\
0.0\end{array}$ & $\begin{array}{r}0.0 \\
0.0 \\
108.6\end{array}$ & \\
\hline $\begin{array}{l}\text { Operating Supplies } \\
\text { Rolling Stock }\end{array}$ & $\begin{array}{l}0.0 \\
0.0\end{array}$ & $\begin{array}{l}0.0 \\
0.0\end{array}$ & \\
\hline $\begin{array}{l}\text { SUBTOTAL } \\
\text { SUBTOTAL ( } x-\operatorname{COA} \& \text { Ges) }\end{array}$ & $\begin{array}{l}63.7 \\
30.5\end{array}$ & $\begin{array}{l}220.3 \\
151.6\end{array}$ & \\
\hline \multicolumn{4}{|l|}{ Fixed Costs } \\
\hline $\begin{array}{l}\text { \% \& Total Plant Costs } \\
\text { Fixed Costs, MMASy (1 ge(t) }\end{array}$ & $\begin{array}{l}4.78 \\
31.5 \\
\end{array}$ & $\begin{array}{l}4.70 \\
55.1 \\
\end{array}$ & \\
\hline TOTAL & 952 & 275.4 & \\
\hline \multicolumn{4}{|l|}{ COST OF PRODUCTION, '8OSMASCF' } \\
\hline $\begin{array}{l}\text { Operating costs } \\
\text { Capital Cost (@ 19.1 s/y) }\end{array}$ & $\begin{array}{l}0.7 \\
0.9 \\
\end{array}$ & $\begin{array}{l}2.0 \\
\underline{1.6}\end{array}$ & \\
\hline TOTAL & 1.56 & 3.51 & $\begin{array}{l}\text { JDFOX } \\
11 / 07 / 91\end{array}$ \\
\hline PRODUCTION, MANSCF/C.YA & 1412 & 1412 & $08: 58 \mathrm{AM}$ \\
\hline
\end{tabular}




\section{TABIE V}

COAL GASIFICATION--COMPARISONS ON COSTS OF PRODUCTION

(Wyodak Coal; 1986 MM!)

\section{GAS-FIRED BOILER W/O TUABOGENERATOR}

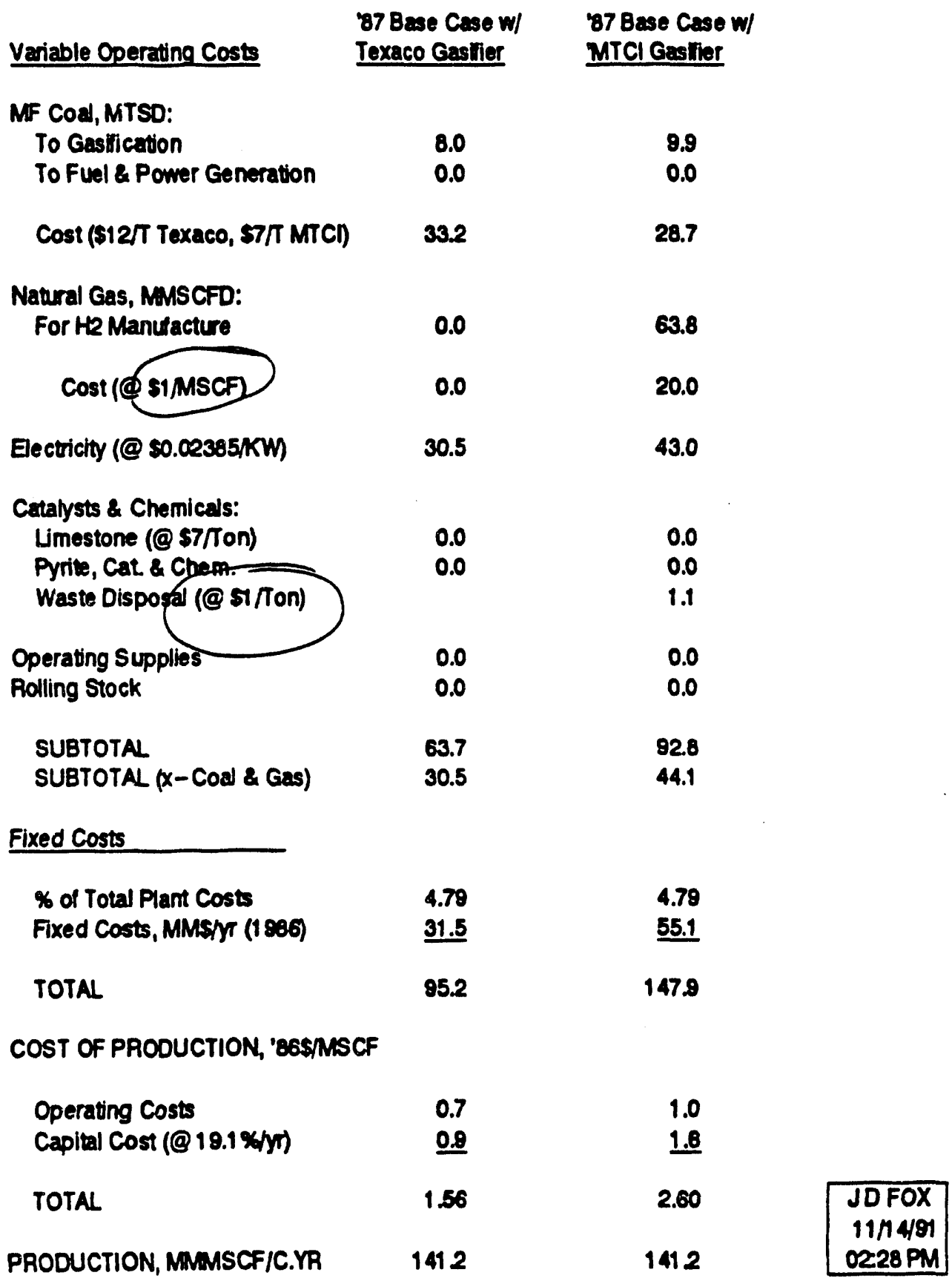


COAL GASIFICATION-SENSITIVITIES ON COSTS OF PRODUCTION

\section{Process Descriotion(1)}

Costs of Production. S/MSCF (1986) Operating Capital Total Diff.

Texaco Gasifier:

0.7

0.9

1.56

Base

MTCI Gasifier Options:

FBC and Turbogenerator.

0.8

1.8

2.65

$+1.09$

w/ $0.058 \$ / k w$ Power

1.1

1.8

2.89

$+1.33$

FBC $w / 0$ Turbogenerator

0.9

1.6

$2.46+0.90$

w/ $0.058 \$ / k w$ Power

1.3

1.6

2.89

$+1.33$

FBC and Turbogenerator,

0.7

1.5

2.18

$+1.62$

No $\mathrm{CO}_{2}$ made in gasifier

FBC $w / 0$ Turbogenerator, No $\mathrm{CO}_{2}$ made in gasifier

0.7

1.3

2.02

$+0.46$

Gas-Fired Boller w/o

Turbogenerator

$\begin{array}{llll}2.0 & 1.6 & 3.51 & +1.95 \\ 1.0 & 1.6 & 2.60 & +1.04\end{array}$

$w / \$ 1 /$ ton Char Disposal, $\$ 1 /$ MSCF Nat. Gas

(1) Key:

FBC--Fluidized Bed Combustor burns char from gasifier, supplies steam to gasifier and process.

Turbogenerator--Produces power (otherwise purchased) from steam-to-gasifter pressure let-down.

Gas-Fired Boiler-supplies steam to gasifier and process; char is wasted at $\$ 100 /$ ton.

Operating labor and maintenance costs are excluded. 

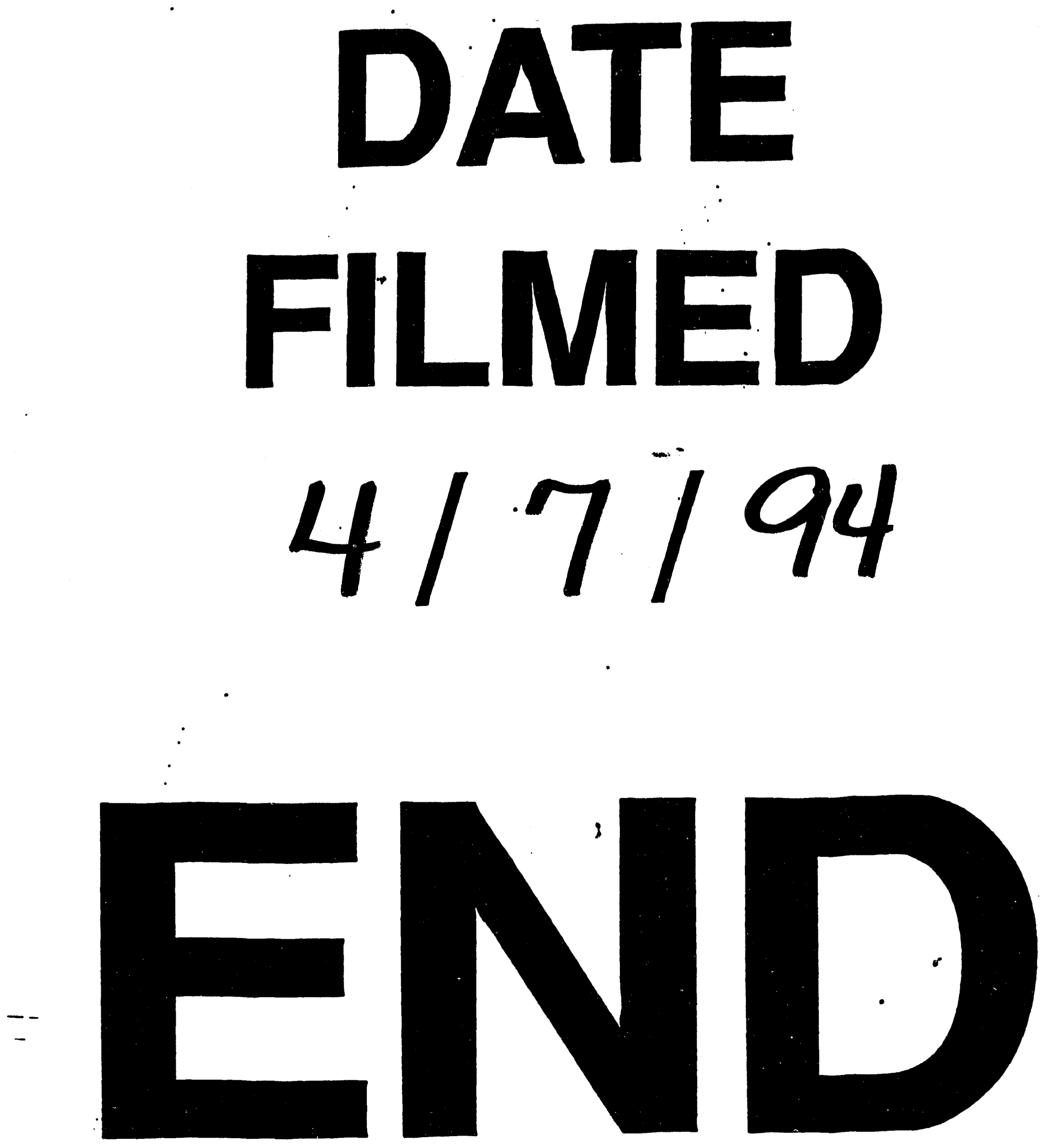
